\title{
LUCIANA ALVES
}

\section{Significados de ser branco - a brancura no corpo e para além dele}

Dissertação de mestrado apresentada à Faculdade de Educação da Universidade de São Paulo para a obtenção do título de Mestre em Educação.

Área de concentração: Sociologia da Educação Orientadora: Profa Dra Marília Pinto de Carvalho

São Paulo 
AUTORIZO A REPRODUÇÃO E DIVULGAÇÃO TOTAL OU PARCIAL DESTE TRABALHO, POR QUALQUER MEIO CONVENCIONAL OU ELETRÔNICO, PARA FINS DE ESTUDO E PESQUISA, DESDE QUE CITADA A FONTE.

Catalogação na Publicação

Serviço de Biblioteca e Documentação

Faculdade de Educação da Universidade de São Paulo

$37.047 \quad$ Alves, Luciana

A474s Significados de ser branco - a brancura no corpo e para além dele / Luciana Alves; orientação Marília Pinto de Carvalho. São Paulo: s.n., 2010.

194 p.; anexos

Dissertação (Mestrado - Programa de Pós-Graduação em Educação. Área de Concentração: Sociologia da Educação) - - Faculdade de Educação da Universidade de São Paulo.

1. Raça 2. Ser branco 3. Brancura 4. Branquitute I. Carvalho, Marília Pinto de, orient. 


\section{Folha de aprovação}

Luciana Alves

Significados de ser Branco - a brancura no corpo e para além dele

Dissertação apresentada a Faculdade de Educação da Universidade de São Paulo para a obtenção do título de Mestre em Educação

Área de concentração: Sociologia da Educação

Aprovado em

Banca Examinadora

Prof. Dr.

Instituição Assinatura

Prof. Dr.

Instituição Assinatura

Prof. Dr.

Instituição Assinatura 


\section{DEDICATÓRIA}

À minha mãe, exemplo de força e integridade À minha gêmea, meu espelho, minha inspiração 


\section{AGRADECIMENTOS}

À minha mãe, irmã e sobrinha, Ana, Adriana e Juliana, pela paciência e apoio durante minha jornada no mestrado.

À minha orientadora Marília Pinto de Carvalho, por me ensinar com quantas cores se faz uma análise e por me incentivar a trilhar novos caminhos na pesquisa sobre relações raciais.

Aos professores e professoras que disponibilizaram parte de seu tempo livre para contribuírem com esta pesquisa, partilhando comigo suas concepções a respeito das relações raciais brasileiras.

Às participantes da banca examinadora do Relatório de Qualificação Nilma Lino Gomes e Fúlvia Rosemberg pelas preciosas sugestões e críticas que auxiliaram na reelaboração das análises preliminares e contribuíram para a finalização desta dissertação.

Aos professores e professoras da Universidade de São Paulo, em especial aqueles que coordenaram as disciplinas cursadas ao longo do mestrado: Belmira Bueno, Maria da Graça J. Setton, Roseli Fischimann, Heloisa B. de Almeida e Antonio Sérgio A. Guimarães.

Aos amigos do grupo Educação e Relações de Gênero pelas diversas leituras e sugestões elaboradas às reflexões preliminares do estudo aqui apresentado.

Às amizades feitas durante a trajetória do mestrado: Andréia B. Resende, Daniele P. Kowalewski, Luciana Brancallion, Carolina de Paula Teles, Ana Paula Santiago, Maria Cristina Cavaleiro, que tornaram menos árduo o caminho percorrido durante a pesquisa. 
Receio que alguns leitores, impressionados com os aspectos verbais aparentes deste estudo, nele descubram intenções agressivas. A esses leitores asseguro, com sinceridade, que o meu propósito é, ao contrário, generoso e pacifista.

Guerreiro Ramos 


\section{RESUMO}

ALVES, Luciana. Significados de ser branco - a brancura no corpo e para além dele. Dissertação (Mestrado) - Faculdade de Educação, Universidade de São Paulo, São Paulo, 2010.

O presente trabalho tem por objetivo investigar as concepções de professores da educação básica a respeito do que significa ser branco. Para sua efetivação foram analisados trabalhos teóricos sobre a questão racial, em especial aqueles dedicados ao estudo da branquitude, bem como realizei pesquisa empírica que englobou observação participante em curso sobre a temática racial destinado a docentes e entrevistas com professores de diferentes pertenças raciais. As análises evidenciaram que a condição de ser branco se relacionou a duas dimensões: uma corpórea, construída com base em características físicas que permitem a classificação de pessoas e grupos como brancos, e outra não material (simbólica). Esta última subdividiu-se em dois patamares: um idealizado, em que se verificavam associações arbitrárias entre ser branco e valores e outro relacionado às experiências vividas por pessoas brancas, fossem os docentes entrevistados, neste caso os autoclassificados brancos, fossem pessoas com as quais os docentes negros e brancos conviveram. O primeiro patamar foi denominado idealização branca e caracterizou-se pela construção do branco como grupo privilegiado e como ideal ético, estético, econômico e educacional a ser alcançado pelos sujeitos. O segundo patamar da brancura não só desmistificou a idealização branca por meio de descrições que sugeriam que as experiências de vida de pessoas brancas eram entrecortadas por eixos de subordinação diferentes do de raça, como a reforçou, já que certos relatos ratificaram alguns significados de ser branco, principalmente os relacionados à opressão racial e ao privilégio institucional concedido a brancos e citado por eles mesmos ou por docentes negros.

Palavras-chave: Raça. Ser branco. Brancura. Branquitude. 


\begin{abstract}
Alves, Luciana. Meanings of being white - the whiteness in the body and beyond. Master's Thesis (Master's Degree) - Faculdade de Educação, Universidade de São Paulo, São Paulo, 2010 .

The aim of this study is to examine the meanings of being white to teachers of Basic Education in the city of São Paulo, State of São Paulo, Brazil. In order to accomplish it, theoretical studies concerning race, specially those on whiteness, were analysed and empirical study that included participant observation in a course about race adressed to teachers and interviews with racially diverse teachers were carried out. The analyses of the interviews showed that the condition of being white was related to two dimensions: a bodily one, which refers to physical features such as skin color and hair type, upon which individuals and groups are classified as whites, and a symbolic dimension. The latter revealed two levels of meaning. In the first level, called white idealization, whiteness was arbitrarily associated to generic values, while the second one included the senses of being white experienced by the teachers in their own lives. White idealization corresponded to a set of ideas about white people as a privileged group and an aesthetic, ethical, educational and economic ideal that people aim to achieve. This set of ideas either lost its force in descriptions that showed different subordination factors - social class, gender and geographic origin - superposing to whiteness or was reinforced by accounts in which whiteness was linked to racial oppression and white privilege.
\end{abstract}

Keywords: Race. Being White. Whiteness. 


\section{Sumário}

PARTE I - DELINEANDO O OBJETO DA PESQUISA

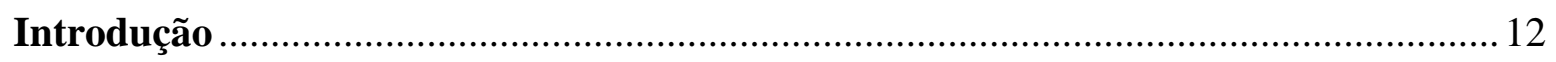

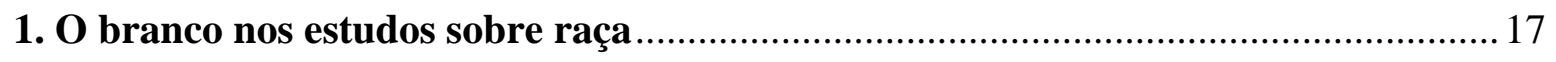

$1.2 \mathrm{O}$ branco em foco - Estudos críticos da branquitude................................................26

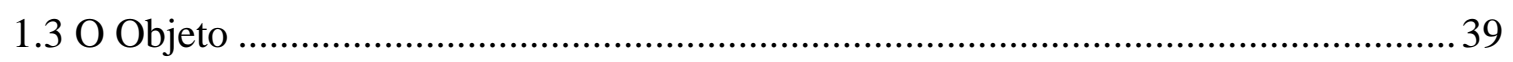

2. Sobre metodologia, técnicas e escolha dos sujeitos.................................................. 41

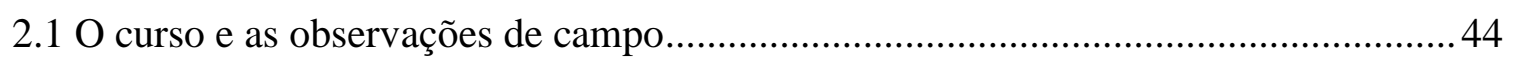

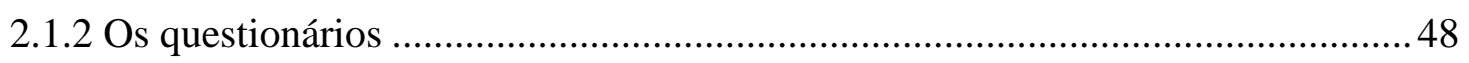

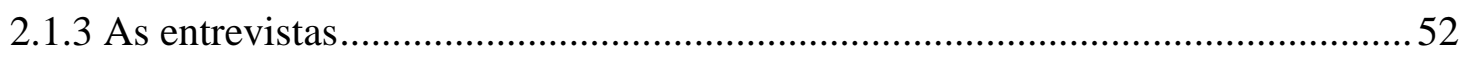

2.2 As subjetividades em contato na pesquisa...........................................................53

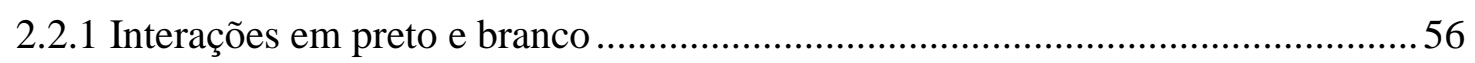

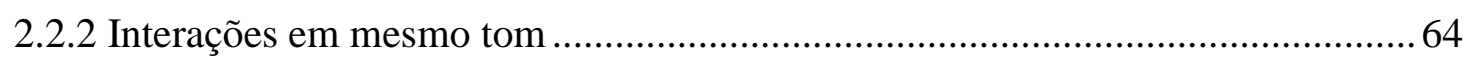

2.4 Princípios e procedimentos de análise....................................................................... 72

PARTE II - SIGNIFICADOS DE SER BRANCO

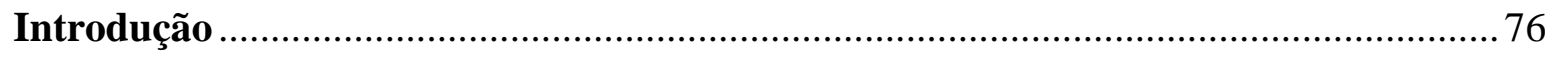

3. A brancura no corpo? - Classificação racial dos sujeitos da pesquisa …………........78

3.1 Fluídas fronteiras - miscigenação, pureza e a classificação racial.............................. 84

4. A brancura além do corpo - ser branco como um valor ............................................ 101

4.1 - Significados de ser branco e hierarquizações da brancura ...................................... 112

4.1.1 A castidade é branca e feminina - distinções de gênero nos significados de ser

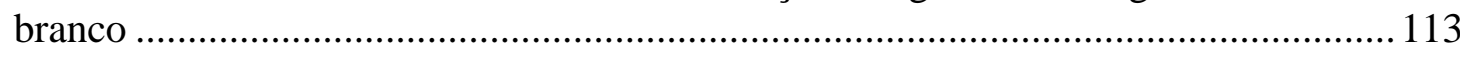

4.1.2 Ser branco e pobre é ser racista cordial - distinções nos significados de ser branco em função das condições socioeconômicas.............................................................. 120

Reelaborando fronteiras de classe e raça - discriminação racial e os significados de ser branco 
5. Aproximação e distanciamento dos significados de ser branco

5.1 Menos brancos? - Posições subordinadas e o acesso aos significados de ser branco136 5.2 Quase brancos? - posições privilegiadas e o acesso aos significados de ser branco 141

6. Mobilizando os significados de ser branco na escola 152

6.1 Ser branco, ser herói - o branco nos conteúdos e materiais escolares 153

6.2 Os eventos - espaços de brancura 158

6.3 Quem pode ou não mobilizar os significados de ser branco na escola? 163

7. Considerações finais 171

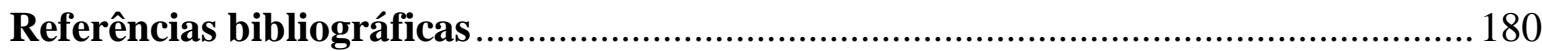

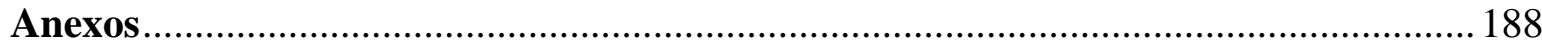

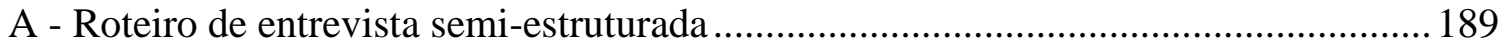

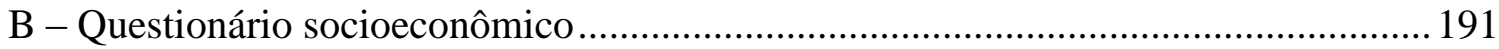

C - Termo de consentimento livre e esclarecido............................................................ 193 
PARTE I - DELINEANDO O OBJETO DA PESQUISA 


\section{Introdução}

No Brasil, com a efervescência dos debates em torno de ações afirmativas voltadas para negros, uma questão emergiu como central para a efetivação de políticas públicas destinadas à erradicação da desigualdade racial: quem é negro? Em outras palavras, quem seriam os beneficiários das ações reparadoras que vêm sendo discutidas?

Analisando os estudos das relações raciais, percebi que essa questão, aparentemente nova, vem sendo debatida há tempos, sobretudo nas pesquisas que se dedicaram a investigar as maneiras como brasileiros se classificam racialmente. A pergunta permanece atual tendo em vista as novas demandas políticas, e oculta uma pergunta primeira, feita antes da definição de quem pertence ou não a esse grupo racial: “o que é um negro?” Depende. O significado do termo passa pela "visão de quem o utiliza, isto é, para compreender as versões existentes do termo negro, necessitamos saber quem o emprega" (PIZA e ROSEMBERG, 2002b, p.109, grifo das autoras).

Alguns diriam que negros são descendentes de africanos, utilizando a expressão politicamente correta afrodescendentes; outros, que o termo se define menos em função da ascendência e mais das características físicas: um negro seria aquele de tez escura, cabelos crespos e lábios grossos; e ainda outros defenderiam que, dada a proximidade dos indicadores socioeconômicos da parcela da população que se autodenomina preta e da que se autodenomina parda, negros seriam a soma de ambas as categorias de cor. Isso sem contar as inúmeras definições vigentes ao longo da história da humanidade construídas com base em discursos divinizados ou a partir das teorias raciais cunhadas no século XVIII.

Essas diferentes definições são fruto dos contextos sociopolíticos em que foram elaboradas e não necessariamente invalidam umas às outras, podendo coexistir em acordo ou concorrência, além de não abarcarem a totalidade de sentidos com que o termo negro é empregado. São poucos, porém, os que se colocaram a mesma pergunta substituindo o sujeito da interrogação: o que é um branco? Se a indagação fosse feita a um cientista do século XIX, adepto das teorias raciais, a resposta poderia ser: é todo o ariano de sangue puro. Já no século XXI, não seria fácil responder à questão de maneira tão direta e segura.

Com a superação do conceito de raça em sua acepção biológica, adotou-se como premissa básica no desenvolvimento de estudos das relações raciais que as pessoas brancas ou 
negras não são naturalmente de um modo ou de outro: sua raça é fruto do que Lenoir denominaria "um trabalho social de enunciação" (LENOIR, 1996, p. 62). Essa postura por si só problematizaria o verbo "é" utilizado na formulação da pergunta anteriormente citada, uma vez que tornamo-nos racializados, forjamos identidades raciais, nas relações que estabelecemos e nos discursos aos quais estamos expostos ao longo de nossa trajetória de vida (COSTA, 1990).

Dado o caráter não ontológico da brancura e assumindo que ela pode ser definida de maneiras diferentes dependendo de quem, quando e onde ela é enunciada, a pergunta base deste estudo é: o que significa "ser branco"? As aspas se justificam tendo em vista que a ideia de existência sintetizada no verbo "ser" é contingente e localizável, mas não serão usadas ao longo do texto de modo a facilitar sua leitura.

Para chegar a essa formulação, aparentemente simples, foram necessários, pelo menos, dois anos de leitura de trabalhos teóricos, realização de pesquisa de campo, diversas leituras de materiais empíricos - notas de campo e transcrições de entrevistas - e sugestões e críticas elaboradas às versões preliminares do texto.

Na construção do objeto de pesquisa, deparei-me com inúmeras dificuldades: escolha do campo, tradução de referencial teórico do inglês, inquietações quanto à interferência de minha pertença racial, dúvidas em relação à objetividade das interpretações.

Posso afirmar que o problema do estudo aqui desenvolvido se delineou apenas após o exame de qualificação. Assumindo as implicações éticas e metodológicas decorrentes da definição tardia do objeto de investigação, considero que adotei integralmente a premissa de que

O bom trabalho de ciência social de hoje não é, e habitualmente não pode ser, feito de uma "pesquisa" empírica claramente delineada. Compõe-se, antes, de muitos estudos bons, que em pontos-chaves encerram observações gerais sobre a forma e a tendência do assunto Assim, a decisão - quais são esses pontos? - não pode ser tomada enquanto o material existente não for retrabalhado e estabelecidas formulações gerais hipotéticas (MILLS, 1969, p. 218).

Quando fui a campo realizar a coleta de dados, os propósitos do estudo estavam embasados no conceito de identidade racial e o intuito era abarcar tanto a negritude entendida como identidade construída por pessoas negras - quanto a branquitude - identidade construída por pessoas brancas. Esses objetivos fundavam-se na crença de que negritude e 
branquitude eram construções que tinham sustentação no corpo objetivamente pensado como branco ou negro, ignorando que o próprio corpo não pode ser separado das construções sociais que lhe dão materialidade.

Desse modo, o projeto inicial baseava-se em duas premissas que considero atualmente superadas: a primeira delas de que a cor da pele dos sujeitos condicionava a construção de uma ou outra identidade racial, e a segunda, conseqüência da anterior, atrelava as construções sobre raça à caracterização racial dos falantes, ou seja, acreditava que o contato com negros propiciaria dados sobre a negritude e o contato com brancos, sobre a identidade branca. Quando os sujeitos da pesquisa foram convidados para participar da entrevista, esta era a concepção que norteava o trabalho.

Ao entrar em contato com literatura sobre branquitude, pude pensar a brancura para além de sua expressão no corpo de pessoas reconhecidas socialmente como brancas. Dentre essas investigações, o trabalho de hooks (1999) sobre as representações da branquitude no imaginário de pessoas negras forneceu-me as primeiras pistas para a elaboração de um objeto de pesquisa que não se baseasse em sujeitos e identidades, mas em concepções sobre a brancura e sobre a raça, investigando como essas concepções dão forma às relações estabelecidas pelas pessoas, independentemente de sua pertença racial.

$\mathrm{Na}$ perspectiva analítica de hooks, a branquitude funciona como construção social presente no imaginário de sujeitos e só em parte tem a ver com a brancura manifesta no corpo de pessoas reconhecidas como brancas. Em outros termos, a leitura de seu artigo me permitiu compreender que não é preciso ser branco para construir concepções a respeito da brancura.

Com base nessa premissa, reli as entrevistas buscando falas que remetessem ao grupo branco e pude verificar que autoclassificados negros e brancos tinham concepções muito semelhantes a respeito de ser branco, o que indicava que ao falar do corpo, da cor - da brancura -, das identidades raciais, da ideia de raça ou dos comportamentos relacionados ao grupo branco, os entrevistados estavam a falar sobre uma categoria mais abrangente que continha essas diferentes dimensões da brancura: a branquitude.

Todavia, ao empregar o conceito de branquitude na formulação do problema de pesquisa, uma nova dificuldade emergiu: os estudos construídos com base no conceito se referiam a realidades raciais bastante diferentes da brasileira, contextos em que a classificação racial é mais polarizada e a linha de cor é definida de modo mais evidente. Durante o exame 
de qualificação, recebi a sugestão de abandonar o conceito e concentrar as análises na categoria branco, problematizando, ao final do estudo, as possibilidades de diálogo entre as construções teóricas de branquitude e os resultados desta pesquisa. Como será possível perceber, essa sugestão foi incorporada na medida do possível, dado o desafio teórico nela embutido.

Desse modo, defini como objeto de estudo as concepções construídas por docentes negros e brancos a respeito da brancura. E com o desenrolar da análise denominei tais construções de significados de ser branco.

Para efetivar essa investigação foram entrevistados dez professores da educação básica autoclassificados negros ou brancos que haviam participado de um curso sobre a história do negro no Brasil, curso construído com base nos debates atuais acerca da definição do grupo negro e da ressignificação da negritude.

Dada a escassez de trabalhos acadêmicos que versassem sobre o tema e que atentassem para as particularidades das relações raciais brasileiras ${ }^{1}$, oferecendo embasamento à análise, optei por realizar um estudo basicamente descritivo, embora aponte algumas interpretações ao longo do trabalho.

Nas páginas seguintes, procuro descrever não apenas os resultados da pesquisa, mas os caminhos percorridos para a sua efetivação, destacando as dificuldades enfrentadas e as estratégias desenvolvidas para sua superação, além de atentar para a sua relevância no processo de análise.

Dividi as reflexões em duas partes. A primeira delas, denominada Delineando o objeto da pesquisa, é composta por dois capítulos nos quais sintetizo o referencial teórico, dando especial atenção aos estudos da branquitude, e os procedimentos metodológicos que viabilizaram a investigação.

A segunda parte, denominada Significados de ser branco, apresenta os resultados da pesquisa e está dividida em quatro capítulos construídos de modo a evidenciar as diferentes dimensões da brancura presentes nos depoimentos: sua expressão nos corpos dos socialmente reconhecidos como brancos; as construções a respeito da brancura que não dizem respeito apenas ao corpo, mas a comportamentos e valores convencionados como brancos; as

\footnotetext{
${ }^{1}$ Exceção dos estudos de Piza (2002), Bento (2002) e Oliveira (2007), descritos no capítulo I.
} 
diferenças nessas construções em decorrência do sexo e das condições socioeconômicas; e, por fim, as maneiras como as concepções sobre a brancura se fazem presentes na trajetória escolar dos sujeitos.

Nas considerações finais, retomo as discussões relacionadas ao referencial teórico, problematizando-as à luz dos resultados da pesquisa, de modo a avançar o entendimento de como os estudos críticos da branquitude foram utilizados na compreensão do material empírico coletado. 


\section{O branco nos estudos sobre raça}

Em alguns estudos atuais sobre a questão racial, no Brasil, tem-se afirmado a ausência de investigações cujo foco recaia sobre o branco (BENTO, 2002; OLIVEIRA, 2008). De maneira geral, as pesquisas privilegiam discussões sobre classificação racial, existência de preconceito e discriminação, desigualdades sociais entre negros e brancos, entre outros objetos, que, embora se refiram ao grupo branco em contraposição ao negro, por vezes indiretamente, dispensam reduzida atenção para investigar as maneiras como pessoas autoidentificadas brancas constroem sua identidade, atribuem significado à cor de sua pele ou ignoram sua pertença racial.

Essa lacuna pode ser apenas parcialmente afirmada, já que diferentes trabalhos alguns realizados no contexto brasileiro - apresentam discussão (realmente reduzida se comparada aos estudos com foco no negro) sobre o grupo racial branco. Este grupo foi discursivamente construído como raça superior, culturalmente dominante ou privilegiada nas relações que estabeleceu com outros grupos. As diferentes formas de conceituar o branco indicam que a brancura foi interpretada de maneiras distintas ao longo de nossa história, dependendo das ideias correntes em cada contexto.

Num primeiro momento, os simbolismos religiosos, ou divinizados, forneceram as bases de conceituação da brancura. Já na Antiguidade, cores claras e escuras eram explicadas a partir de oposições simbólicas fundamentadas na dicotomia bem versus mal, sugerindo uma primeira polaridade: claro/escuro, branco/preto, em que o primeiro elemento do binômio carregava sentidos positivos e o segundo, negativos (HOFBAUER, 2006). Com a ascensão do Cristianismo, as ideias de pecado e paganismo, entre outras, serviram para estigmatizar a posição dos negros relacionando sua cor a erros cometidos por personagens bíblicos, como Cã (BASTIDE, 1967, GUIMARÃES, 2008).

Os termos raciais atualmente utilizados para descrever indivíduos têm uma história de aparição relativamente recente, quando dos contatos mais sistemáticos entre europeus, nativos americanos e africanos, no contexto da expansão colonial europeia, ocasião em que se tornou necessária a elaboração de termos genéricos que remetessem não apenas à origem geográfica, mas às diferenças físicas observadas (GUIMARÃES, 2008).

\footnotetext{
${ }^{2}$ Na Bíblia, Cã, filho de Noé, foi amaldiçoado após caçoar da nudez e embriaguês de seu pai. Como castigo, tornou-se negro e seus descendentes tornaram-se escravos dos irmãos brancos.
} 
Durante os séculos que antecederam o racismo científico, explicações de cunho religioso foram paulatinamente substituídas por ideias científicas depois da cisão entre Igreja e Ciência promovida pelo pensamento Iluminista. As primeiras interpretações que rompiam com a concepção divinizada da diversidade de aparências humanas tendiam a atribuir ao clima, à geografia e à cultura a origem de tal diversidade (BUFFON, apud SCHWARCZ, 1993, p. 46). Essas condições, na Europa, teriam favorecido o pleno desenvolvimento da raça humana, razão pela qual os habitantes dessa parte do mundo foram considerados racialmente superiores. Embora estivesse presente a ideia de uma humanidade una, estabelecia-se nessa perspectiva um senso de hierarquia de bases etnocêntricas. Ainda que o status de superioridade da raça branca não fosse questionado, havia certa maleabilidade da situação racial dos indivíduos considerados inferiores, uma vez que se acreditava que se expostos às mesmas condições culturais e climáticas que brancos, estes dariam origem a uma descendência também branca (SCHWARCZ, op. cit.; HOFBAUER, op. cit.).

Foi apenas nos séculos XVIII e XIX, com a emergência do conceito de raça, que as cores passaram a denotar o pertencimento a grupos humanos distintos em essência, cujas características condicionariam a ocupação de espaços sociais também distintos. Surgindo em meio às revoluções burguesas e ao imaginário liberal, a categoria raça servia aos interesses das elites brancas, para as quais era "um modelo teórico viável na justificação do jogo de interesses" entre brancos brasileiros e o grande número de negros libertos (SCHWARCZ, 1993 p. 18).

Desse modo, os significados relacionados às cores tornaram-se essencializados e fizeram convergir cor e raça:

[...] durante muito tempo, a "cor da pele" não foi vista como dado natural objetivo (ou biológico). [...] Com a naturalização (biologização e, mais tarde, genetização) das diferenças humanas, a cor transformar-se-ia num critério de exclusão cada vez mais essencialista; isto é, tornar-se-ia um dado cada vez menos "contextual" e menos "negociável” (HOFBAUER, op. cit., p. 35).

Como é possível constatar, os significados atribuídos à cor branca e posteriormente à raça branca, ao menos no pensamento ocidental, não foram substancialmente modificados, mas ganharam caráter biologizante justificado pela ciência. Assim, os sentidos naturalizados da cor instalaram-se no imaginário científico e, posteriormente, no popular, como essências sintetizadas no conceito de raça. Em cada um desses sucessivos processos de naturalização, do 
sentido religioso ao geográfico e deste ao biológico, a condição de ser branco foi construída de modo a reforçar o que já se tinha como dado: a superioridade, em diferentes âmbitos, daqueles que se reconheciam e eram reconhecidos como brancos.

Em virtude dessa crença, diversos trabalhos que tomaram a raça em sua acepção biológica sugeriram estratégias para que a suposta superioridade racial do grupo branco se mantivesse incontestável, dando origem às primeiras políticas eugênicas e às teorias fatalistas a respeito da miscigenação. A premissa de que seres humanos provinham de centros de criação distintos e apresentavam, por isso, essências diferentes e imiscíveis, reforçava cada vez mais o caráter intrínseco da raça, tomando a aparência como mera conseqüência da pureza racial. O fenótipo claro, conseqüência de relações inter-raciais, não era suficiente para caracterizar um indivíduo como branco e miscigenação tornou-se sinônimo de degenerescência.

Esse caráter estático da raça durante o século XIX e início do XX, marcado pela rígida separação entre os grupos raciais e pela condenação à hibridização, sentenciava o Brasil, já mestiço, ao atraso e ao desaparecimento frente às nações cuja população era definida como majoritariamente branca. A solução encontrada por intelectuais brasileiros foi fazer certos ajustes nas teorias raciais em voga, de modo que elas pudessem adequar-se à realidade brasileira. Esses ajustes culminaram em teses de branqueamento que, sem questionar a superioridade branca, previam que por meio de sucessivos cruzamentos inter-raciais a população brasileira tornar-se-ia branca num curto espaço de tempo (SCHWARCZ, 1993). Teses que se configuraram numa das origens das peculiaridades do pensamento racial brasileiro.

A incorporação dos discursos racistas europeus dos séculos XVIII e XIX, fazendo-se as modificações necessárias para a sua adequação à realidade brasileira, disponibilizou narrativas especificamente nacionais aos brancos, nas quais sua superioridade não foi contestada, mas sua miscigenação, reivindicada.

O branco brasileiro seria definido de maneira diferente daquela aceita no meio científico das teorias raciais. Esse grupo seria determinado menos em função de sua origem europeia e mais em virtude de sua aparência física, marcando uma primeira diferença entre o significado de ser branco no contexto europeu ou norte-americano - construído com base na ideia de pureza racial - e o significado de ser branco no Brasil (GUIMARÃES, 2008, p. 50). 
Esse esforço de transformação das primeiras teorias raciais tornou-se desnecessário a partir da desconstrução do caráter biológico da raça, que fora utilizado na elaboração de discursos nacionalistas e racistas com resultados desastrosos para a humanidade. Cientistas de diferentes áreas do conhecimento dedicaram-se à desconstrução do conceito de raça, ao menos teoricamente: na Biologia verificou-se a inexistência de evidências genéticas que justificassem a divisão da humanidade em subespécies, propondo-se o conceito de população; Nas Ciências Humanas as diferenças observáveis entre as então chamadas populações foram consideradas fruto da cultura e explicadas em termos étnicos e não raciais (GUIMARÃES, 2006). A superação teórica, no entanto, não garantiu que ideias sobre diferenças inatas entre os seres humanos fossem prontamente superadas nas práticas sociais nem que as hierarquias entre negros e brancos fossem suprimidas, mesmo em trabalhos científicos.

Entre os principais autores brasileiros a defender a nova forma de teorizar sociedades multirraciais como encontro de culturas e não de raças superiores e inferiores, encontra-se Gilberto Freyre, que criticava propostas arianistas de melhoria genética da população por meio da miscigenação e propunha uma forma inédita de interpretar a sociedade brasileira: amálgama não apenas de raças, mas de culturas, que teria conferido ao Brasil uma configuração ímpar no cenário mundial.

Embora aposte na miscigenação, Freyre (2006 [1933] e 2006 [1936]) se refere à parte da população brasileira como branca, construindo discursivamente esse personagem tipicamente brasileiro para além da crença na pureza racial. O autor investe numa definição social de brancura que transcende a noção de raça biológica, porém em sua obra está presente a premissa de que o branco continua a ser o ideal de cultura e de raça que outros grupos almejariam alcançar por meio da miscigenação ou pela aquisição das "insígnias de raça branca", símbolos de ascensão econômica e intelectual que permitiriam aos mestiços "ascenderem para brancos", demonstrando como o pensamento racial da época ainda estava imbuído dos significados de superioridade apregoada nas teorias raciais de outrora (2006 [1936], p. 709).

$\mathrm{Na}$ perspectiva freyreana, tornar-se branco equivaleria a um processo complexo que envolve não apenas as características físicas, mas, também, as características sociais e econômicas que possibilitariam o ingresso na brancura. $\mathrm{O}$ branco presente nas reflexões de Freyre corporifica o "equilíbrio de antagonismos" (ARAÚJO, 2005 [1994]) que perpassa toda 
a obra do autor, sendo ao mesmo tempo inexistente do ponto de vista racial (biológico) somos todos mestiços - e existindo do ponto de vista social - há um grupo que se percebe e é percebido como branco.

Sendo assim, entender a mestiçagem como equivalente da ausência de brancos no contexto nacional, ou mesmo no pensamento freyreano, obriga a uma revisão da interpretação estritamente biológica da raça. No entanto, se tomarmos a raça como construção social, cujos significados não se limitam ao sangue ou ao genótipo, ser branco no Brasil não corresponde a uma ascendência unicamente europeia. O branco brasileiro, assim como o negro, prescinde da pureza racial para classificar-se, mesmo porque essa pureza só existe nas teorias racistas. A marca somática, o fenótipo, é o principal elemento de classificação racial (NOGUEIRA, 2007 [1954]).

Possivelmente esse branco tenha que negociar sua inserção na brancura em outros contextos, principalmente europeus e norte-americanos, ou a definição de quem é branco varie conforme as características do interlocutor. Talvez seja mais difícil caracterizar-se como branco num ambiente elitizado do que na periferia, por exemplo. Essas situações só atualizam o argumento de que a raça (e, conseqüentemente, não apenas a negritude, mas também a condição de ser branco) e a pertença racial são construções sociais que não existem a priori, são gestadas nas relações que se estabelecem em nossa sociedade.

Como salienta Sovik, classificar-se como branco tendo por base critérios de pureza racial é um processo complexo até mesmo na Europa, o que indica que os significados de ser branco vêm sendo modificados também naquele contexto:

Com as recentes ondas de imigração que mudaram a face da Europa e a crescente consciência da secular mistura de populações, a definição da branquidade pela pureza do patrimônio genético europeu torna-se menos importante: a branquidade abre suas asas sobre muitos mestiços sociais, culturais e biológicos, enquanto a Europa não é mais um continente que possa se imaginar como branco (SOVIK 2004, p. 368).

Nesta pesquisa, para além do que propõe Sovik, que parece pressupor apenas uma queda da importância da referência genética, assumi a premissa de que a brancura independe do patrimônio genético e imaginar-se branco é uma condição, desde sempre, socialmente construída. Desse modo, a perspectiva analítica que guiou as reflexões sobre o material 
empírico tem mais a ver com as proposições freyreanas de que tornar-se branco não decorre de uma causalidade divina ou natural nem é um estágio de pureza, como postulavam os discursos naturalizantes anteriormente descritos, mas é condição alcançada mediante o acesso a símbolos associados à brancura e ao fenótipo.

Ao assumir a perspectiva analítica de Freyre é preciso salientar que os pontos-chave de seu pensamento - mestiçagem e democracia racial - foram teórica e politicamente desarticulados por autores norte-americanos e brasileiros, a exemplo de Florestan Fernandes (1965), e pelos movimentos negros (GUIMARÃES, 2001). A ideia de que brancos brasileiros seriam definidos em termos mais culturais e sociais que raciais serviu de base à elaboração da crença de que o grupo branco não poderia ser encarado enquanto grupo unido em interesse e benefício próprio.

A crença na miscigenação não apenas conferiu ao branco brasileiro uma cor local, mas permitiu que se forjasse uma narrativa de origem para o Brasil moderno: a democracia racial. Num período em que nações consideradas avançadas tinham na democracia o único modelo político viável, o Brasil, marcado pelo regime militar e pelo totalitarismo, despontava no cenário mundial como país democrático num sentido que outras nações não haviam sido capazes de construir. O racismo e a segregação racial verificados em sociedades multirraciais eram problemas estrangeiros. Aqui, supostamente, membros de grupos raciais diversos experimentariam as mesmas oportunidades de ascensão social e conviveriam sem ter a ideia de raça a moldar suas relações (GUIMARÃES, 2002; 2006). Os olhos do mundo se voltaram para o Brasil numa tentativa de desvendar os fatores sociais que condicionariam a ausência de senso de grupo racial e as bases da democracia racial, assumindo como basilares as concepções de Freyre e consolidando os estudos das relações raciais no país.

\section{Reabilitando a raça com significações sociais - ser branco como posição social}

Embora a raça não fosse considerada realidade objetiva, a crença de que pessoas de cores e traços físicos diferenciados compunham raças diferentes persistiu na caracterização de sociedades encaradas como multirraciais, nas quais discriminação e desigualdade racial continuaram a privilegiar o grupo branco e a prejudicar grupos tidos como racialmente inferiores. Desse modo, a superação científica da raça não foi, necessariamente, seguida de sua superação em outros âmbitos sociais. O racismo em suas diferentes manifestações marcou de 
maneira indelével sociedades multirraciais e tentar compreender como a raça operava de modos distintos em cada contexto nacional foi um dos primeiros objetivos dos estudos das relações raciais.

O conceito de base biológica perdeu sua força ao longo do século $\mathrm{XX}$, dando espaço a um debate calcado em diferenças socioeconômicas e culturais (LARKIN, 2000), mas foi retomado com outros significados, eminentemente sociais e políticos, pelos movimentos negros espalhados pelo mundo, sendo encarado de forma positiva e reivindicatória da dignidade e do orgulho racial. Além de ser usado por cientistas sociais que enfatizam que a inexistência biológica da raça não corresponde a sua inexistência sociológica (GUIMARÃES, 2002 p. 61).

O conceito antes encarado como biológico é agora considerado por alguns pesquisadores das Ciências Humanas como noção que norteia as relações sociais entre negros e brancos, e será usado ao longo desta dissertação com esse significado. Como afirma Guimarães (op. cit. p.52), "continuamos a nos classificar em raças, independentemente do que nos diga a genética", e essa classificação influencia de maneira decisiva os modos como indivíduos pertencentes aos diferentes grupos raciais se reconhecem ou são reconhecidos pelos outros, assim como as oportunidades de vida de cada um.

Essa influência ocorre de maneiras diferentes, e por vezes antagônicas, dependendo da pertença racial. O que pesquisas sobre relações raciais têm indicado é que classificar-se como branco, no Brasil, equivale a usufruir de melhores condições de vida em todos os âmbitos: psicológico, social, econômico.

Pesquisas de Psicologia Social, por exemplo, ilustram como portar um corpo socialmente identificado como branco propicia ganhos psicológicos numa sociedade estruturada pelo racismo:

O indivíduo branco pode se reconhecer em um "nós" em relação ao significante "corpo branco" e, conseqüentemente, se identificar imaginariamente com os atributos morais e intelectuais que tal aparência expressa, na linguagem da cultura, e que representam aquilo que é investido das excelências do sagrado (NOGUEIRA, 1998, p. 42).

O significante "corpo branco" não funciona como base natural dos significados atrelados à brancura; sua construção é arbitrária, baseada principalmente em demandas 
político-sociais e disputas de poder. Como visto, os significados relacionados ao corpo branco variaram ao longo da história, daí que esse corpo não possua valor intrínseco, ele ganha materialidade a partir dos significados que o constituem. O que não impede a atribuição de privilégio àqueles que são socialmente reconhecidos como portadores "naturais" desse significante: os brancos.

Tais privilégios relacionam dialeticamente ganhos psicológicos, como os descritos por Nogueira (op. cit.), aos de base socioeconômica. $O$ discurso de que formamos uma "metarraça", os mestiços, não se ajusta às estatísticas socioeconômicas que demonstram que os brancos ocupam um lugar social privilegiado, indicando que, a despeito da mestiçagem, perceber-se e ser percebido como branco é indicativo de vantagem estrutural.

As pesquisas baseadas em dados estatísticos foram as primeiras a apontar a existência de uma condição favorável aos brancos, tornando necessário problematizar a afirmação de que os estudos sobre as relações raciais sempre focalizaram sujeitos negros. Esses estudos, ao revelar a existência de privilégio racial, lançaram bases iniciais para reflexão a respeito da dimensão material da raça branca.

Hasenbalg, ainda na década de 1970, ao analisar os modos como negros regulavam seus desejos de ascensão social tendo por base as oportunidades reais disponíveis, formulou aquele que mais tarde se tornaria um dos principais argumentos dos estudos críticos da branquitude, a ideia de que brancos só se constroem como grupo privilegiado a partir da visibilidade conferida aos negros e suas condições desfavoráveis:

A contrapartida do lado dos brancos consiste em ter o negro como contraconcepção, que serve para definir-se a si mesmo. "A autoconfiança" decorre de formar parte de um grupo que goza de supremacia estrutural em si mesma reforça as capacidades pessoais e, portanto, encoraja a realização (HASENBALG, 2005 [1979], p. 209).

O privilégio estrutural apontado por Hasenbalg, e constatado atualmente, pode ser verificado nos indicadores sociais bastante diversos para negros e brancos, embora esses grupos sejam numericamente muito próximos, já que temos uma população de 49,7\% de brancos e $49,5 \%$ de negros ${ }^{3}$. Brancos são proporcionalmente maioria em todos os níveis de ensino, sendo que a diferença cresce à medida que se eleva a escolarização. Recebem maiores

\footnotetext{
${ }^{3}$ Dados do relatório Retrato da Desigualdade. IPEA/2006. O relatório constrói a categoria negro a partir da somatória dos grupos preto e pardo.
} 
salários, têm maior acesso aos benefícios previdenciários e ao saneamento básico. Os indicadores de pobreza e indigência evidenciam uma minoria de brancos. Num país em que 23,8\% das pessoas são pobres, 14,5\% dos brancos pertencem a esse grupo, contra 36,3\% dos negros. Com relação à indigência o quadro se repete: $4,5 \%$ da população que se autoclassifica como branca encontra-se nessa condição, o que representa menos da metade dos $11,8 \%$ dos negros em situação de indigência.

Somos constantemente expostos à afirmação de que, em nosso país, a pobreza tem cor e ela é negra. Isso implica que o oposto também é verdadeiro. Desde os estudos de Hasenbalg a posição privilegiada dos brancos tem sido colocada em pauta, mas as interpretações dessa evidência estatística nem sempre vêm relacionadas à questão racial. Muitas vezes a lógica argumentativa recorre apenas à classe social para explicar as diferenças socioeconômicas e de prestígio entre os grupos raciais.

As explicações tornam-se mais complexas quando se tenta interseccionar classe social e raça. Tal como propõe Harris (1993), a brancura pode ser vivida como propriedade numa sociedade multirracial. A posse desse bem, quase sempre encarada como dádiva popularmente expressa na crença de que nascer mais claro é sinônimo de sorte, permite que brancos acessem mais facilmente determinadas áreas sociais, não só pela persistência de privilégios oriundos da conjuntura colonial, mas pela constante atualização das hierarquias raciais que servem aos interesses, muitas vezes inconfessáveis, do grupo racial que se beneficia dessas hierarquias.

A evidência de que as significações atreladas à brancura permanecem disponíveis nas relações raciais estabelecidas cotidianamente fez emergir a necessidade de teorização mais sistemática sobre a identidade de brancos. Essa identidade, até pouco tempo sem um nome definido para caracterizá-la foi, em fins do século XX, denominada branquitude, tradução ${ }^{4}$

\footnotetext{
${ }^{4}$ Nos textos brasileiros encontrei três traduções para o termo whiteness: branquitude, branquidade e brancura. As mais usadas são branquitude e branquidade, porém o trabalho de Dávila (2006), publicado em inglês como Diploma of Whiteness, foi traduzido para o português como "Diploma de Brancura", expressão que tem implicações teóricas, já que brancura é por vezes sinônimo de cor de pele e a branquitude é mais discursiva que empiricamente observável. O único artigo que explica a escolha do termo branquidade por parte do tradutor é o de Apple (2002), em que Tomaz Tadeu da Silva o justifica como forma de marcar linguisticamente as diferenças ideológicas entre os conceitos de branquidade e negritude. Por apresentarem o mesmo sufixo, os termos branquitude e negritude poderiam ser semanticamente aproximados, mas negritude apresenta significações mais positivas relacionadas ao orgulho racial ou consciência racial, ao passo que branquidade não apresenta a mesma conotação, porém o oposto, como poderá ser observado ao longo das discussões efetivadas neste capítulo. Contudo, neste trabalho, utilizo a primeira tradução a que tive acesso - branquitude -, mantendo as traduções dos originais nas citações diretas de outros autores. Essa opção se justifica tendo em vista que o termo branquitude foi
} 
para o termo em inglês whiteness, e vem sendo teorizada desde então a partir de diferentes enfoques.

A leitura de alguns estudos elaborados com base no conceito de branquitude permitiu o contato com pesquisas que tomaram a condição de branco como foco de sua análise, e não como discussão secundária em trabalhos a respeito da negritude, e estes se constituíram como referencial teórico valioso na proposição das questões norteadoras do meu trabalho. Como se trata de referencial pouco conhecido no Brasil, sintetizo os principais pontos dos Estudos Críticos da Branquitude para, em seguida, enfocar como estes, em conjunto com as reflexões a respeito do conceito de raça, anteriormente discutidas, auxiliaram na construção do objeto da pesquisa.

\subsection{O branco em foco - Estudos críticos da branquitude}

A branquitude emergiu como problema de pesquisa nos Estados Unidos na década de 1990 e se consolidou em países de língua inglesa com estudos realizados em diferentes disciplinas, principalmente Literatura, Comunicação, História, Ciências Sociais e Educação, com o objetivo de deslocar o olhar das investigações sobre raça "das bordas para o centro", elucidando os processos de construção da identidade racial branca (STEYN, 2004, p.121).

Embora a década de 1990 seja usualmente referida como a época de emergência dos estudos críticos da branquitude, diferentes genealogias vêm sendo construídas e não há consenso sobre quem seriam os responsáveis por sua colocação na agenda de pesquisas sobre raça ou quando começaram as primeiras investigações. Comumente autores brancos norteamericanos são citados como os idealizadores desses estudos, e pesquisadores como Dyer (1988), Roediger (1991), Frankenberg (1993) e Allen (1994) são citados como os primeiros estudiosos do tema (GIROUX, 1997).

Em contrapartida, há autores que apontam intelectuais negros do início do século XX, como W.E.B. Du Bois, como os primeiros a se debruçarem sobre a questão da supremacia branca, um dos modos através dos quais a branquitude é conceituada, o que implica que a origem desses estudos seja considerada muito mais antiga do que se supõe atualmente (GARNER, 2007). Desse modo, as investigações sobre a identidade racial branca teriam se 
iniciado "com a crítica negra a respeito de como a branquitude funciona como um privilégio racial, assim como as críticas aos efeitos desse privilégio sobre corpos que são reconhecidos como negros" (AHMED, 2004, p.1, tradução minha).

A despeito das disputas em torno da genealogia dos estudos críticos da branquitude, há pelo menos um ponto consensual relativo à origem sócio-histórica dessa identidade: a branquitude, assim como as demais identidades raciais, é considerada um produto da dominação colonial europeia e, portanto, estaria intimamente relacionada à supremacia branca global, sendo impossível conceituá-la sem atentar para as relações de poder que lhe deram origem (FRANKENBERG, 1993; HARRIS, 1993, STEYN, 2004, entre outros). A vantagem dessa abordagem é que ela toma a condição de ser branco como uma construção social e não como característica intrínseca ou essencial às pessoas classificadas como brancas e, ao fazê-lo, permite que uma identidade a princípio inexistente ou não-marcada 5 seja "tornada visível", possibilitando desvendar os mecanismos de sua construção e manutenção (AHMED, op. cit.).

Mas, o que é possível ver quando a branquitude é tornada visível? O significado atribuído a essa identidade nas diferentes pesquisas às quais tive acesso é variável e, por vezes, conflitante. Há ao menos quatro principais abordagens nos estudos ora discutidos (GARNER, 2007).

A primeira delas se concentrou na investigação dos modos como a branquitude se relacionou ao longo da história com estruturas de poder e dominação social para além de posturas individuais. Nela, a identidade racial branca é construída como sinônimo de poder e visibilidade. Essa interpretação supera o paradigma identitário e procura analisar o modo como sociedades multirraciais construíram garantias de privilégios estruturais e simbólicos para brancos.

Entre esses privilégios, Harris (1993) aponta a associação entre branquitude e propriedade privada, postulando que ambas compartilham um mesmo núcleo conceitual: o direito de excluir, daí que a branquitude seja encarada como uma forma de propriedade e não somente como uma identidade racial. Essa autora dividiu a relação entre branquitude e propriedade em três vertentes: propriedade de corpos, propriedade de terras e propriedade das expectativas sociais. Seja qual for a vertente considerada, a branquitude funciona como

\footnotetext{
${ }^{5} \mathrm{O}$ conceito de não-marcado, em se tratando da identidade racial branca, será discutido adiante.
} 
privilégio racial, "um tipo de status em que a identidade racial branca fornece a base para a alocação de recursos sociais de caráter público e privado", criando a chamada supremacia branca, sistema responsável pela dominação de outros grupos raciais (HARRIS, 1993, p. 1709, tradução minha).

A dominação, considerada uma construção simultânea ao privilégio de raça, ensejou a identificação da branquitude com o terror. Essa associação é derivada da maneira como a supremacia branca se consolidou na sociedade ocidental, segundo Mills, a partir de seis dimensões: econômica, jurídico-política, cultural, cognitivo-avaliativa, somática e metafísica (MILLS, 2003 apud Garner 2007, p.24). A essas diferentes dimensões corresponderam diferentes estratégias sociais, tais como a restrição de acesso à produção e à acumulação de riquezas a grupos raciais subordinados, o estabelecimento de leis de segregação racial, a assimilação ou a exclusão de aspectos culturais dos povos dominados, a generalização da experiência branca e dos conhecimentos produzidos por brancos, os julgamentos em torno da aparência física tornando possível inferir capacidades intelectuais, psicológicas e sociais a partir de sua avaliação e, por fim, a construção da ideia de Humanidade com base num referencial branco. Essas práticas, em parte coincidentes com as conclusões de Harris citadas anteriormente, estão circunscritas ao que Mills denominou "Contrato Racial", sistema restrito aos racialmente homogêneos, sustentado pela violência racial que "assegura vantagens a todos os cidadãos [...] brancos e mantêm a subordinação dos não-brancos” (MILLS, 1997, p. 13-14 apud CARNEIRO, 2005 p. 48).

Nas estratégias destacadas, a branquitude se configura como extremamente visível por meio dos efeitos observáveis de seu poder, dentre eles a discriminação e a violência. Por isso, autoras como hooks e Ahmed são enfáticas ao contestar a proposição de que a branquitude seria uma identidade racial invisível. Esta última acredita que a premissa de que os estudos da branquitude têm o objetivo de torná-la visível só pode ser considerada válida a partir da perspectiva de brancos. Para negros, o objetivo de tais investigações seria "tornar o que já é visível, visível de uma maneira diferente” (op. cit., tradução minha).

A crítica de hooks (1999) é ainda mais incisiva. A autora acredita que:

Em sociedade de supremacia branca, pessoas brancas podem imaginar que são invisíveis para pessoas negras desde que o poder que elas historicamente 
afirmaram em relação aos negros lhes concedeu o direito de controlar seu olhar. Tão fantástico quanto isso possa parecer, pessoas brancas racistas imaginam facilmente que pessoas negras não podem vê-las na medida em que elas não desejam ser vistas por negros (hooks, 1999, p. 168, tradução minha).

Paradoxalmente, os principais autores da segunda abordagem dos estudos críticos da branquitude acreditam que esse poder, com efeitos tão visíveis, permite à identidade racial branca assumir o status normativo que assegura sua invisibilidade. Assim, uma segunda abordagem dos estudos ora descritos é aquela que define a branquitude como identidade construída sobre as bases do poder e da invisibilidade. De acordo com Frankenberg (2004), a história de construção de invisibilidade da branquitude pode resumir-se em quatro fases: aparecer - denominar-se - violar/saquear/apropriar-se - tornar-se invisível. História que se confunde com o projeto modernista de colonização, marcado pela designação de uma série de Outros construídos em oposição a um Eu ocidental e branco que assumiu uma posição de neutralidade frente aos demais grupos racializados justamente pela capacidade de se tornar "a norma e o padrão pelo qual os outros grupos são medidos” (STEYN, 2004, p. 115).

Frankenberg concluiu que além da vantagem estrutural e/ou do privilégio racial (pontos centrais da primeira abordagem dos estudos da branquitude) essa identidade apresenta outras características negligenciadas na primeira abordagem, quais sejam: é um conjunto de práticas culturais usualmente não-marcadas e não-nomeadas ou nomeadas como nacionais, em vez de especificamente raciais, que podem ser geralmente deslocadas para denominações de classe social e etnia, do que resulta sua invisibilidade (FRANKENBERG, op. cit., p.312-313). Seja no currículo escolar (APPLE, 2002; McINTYRE, 1997, SLEETER 1993), na mídia (DYER, 1988) ou no que se considera representativo da cultura nacional (FRANKENBERG, 1993; GARNER, 2007) brancos não são representantes de uma raça, mas são "A” raça humana, constituindo-se como referência natural de ser humano.

Já a capacidade da branquitude de perder-se em denominações de classe social verificase na maior aceitação da ideia de que brancos possam pertencer a classes diferenciadas e agir mais em função dessa pertença do que em favor de sua raça. Roediger (2004) oferece exemplo ilustrativo dessa tendência ao analisar a eleição de um ex-dirigente da Ku Klux Klan - David Duke - para a câmara legislativa em Louisiana, nos Estados Unidos, ocasião em que 
Ofereceu-se aos espectadores a exótica ideia de que, quando os trabalhadores brancos reagem ao desemprego elegendo um destacado adepto da supremacia branca [...] eles estão agindo em termos de classe e não como racistas da classe trabalhadora (ROEDIGER, 2004, p. 49).

Além de subsumir-se em práticas nacionais e dissolver-se na ideia de classe social, a branquitude também se transmutaria em denominações étnicas por meio do uso de subcategorias - como judeu, irlandês ou britânico. Tais denominações baseadas na etnicidade negam a relevância da raça como aspecto estruturante e o papel institucional da branquitude, mantendo o foco sobre as práticas culturais que podem ser trocadas entre pessoas de diferentes grupos étnicos, como a culinária e expressões artísticas (DYER, op. cit. p. 46). A redução da branquitude à etnicidade vem sendo incorporada às práticas de educação multicultural, nas quais as relações de poder desaparecem para dar lugar a descrições de costumes e particularidades culturais relacionadas a grupos considerados culturais e não raciais (SLEETER, op. cit. p. 146).

Outro aspecto que contribui para a construção da invisibilidade da identidade branca se refere à utilização de estereótipos para designar grupos raciais subordinados. A branquitude seria apenas um espaço vazio dependente das construções que faz a respeito de seus outros raciais, definindo-se por seus reflexos nesses outros (GARNER, 2007, p. 43). Essa premissa foi salientada por pesquisas que tiveram entrevistas com pessoas brancas como principal objeto de análise, nas quais os entrevistados respondiam questões a respeito de sua própria condição racial com evasivas ou com descrições sobre negros, postura interpretada como sinal de que, ao falar de outros grupos raciais, entrevistados brancos estavam falando de características que não se aplicavam a eles mesmos (FRANKENBERG, 1993 e McINTYRE, 1997 são exemplos).

Tanto as críticas à abordagem que considera a branquitude uma identidade invisível, quanto os argumentos a favor dessa abordagem são bastante coerentes, permitindo que o paradoxo visibilidade/invisibilidade permaneça atual. Ao tentar dissolver essa contradição, Garner (op. cit.) propôs a utilização do termo "não-marcado" para se referir às práticas cujos efeitos são largamente observáveis, mas que não são racialmente localizadas, tal como proposto por Frankenberg. Esta, por sua vez, revisou suas primeiras conclusões (1993) em artigo publicado no Brasil (2004), em que acrescentou à premissa inicial a ideia de hegemonia, 
concluindo que somente em contextos nos quais a branquitude chega a tal estágio é que ela pode se aproximar da invisibilidade, tornando suas práticas assinaladas como neutras, nacionais, ou ainda, como universais.

Dentre os fatores que possibilitam a universalização da experiência branca estariam a associação entre a branquitude e valores socialmente estimados, conceituação que caracteriza uma terceira abordagem dos estudos críticos da branquitude de acordo com Garner (op. cit.). Nessa abordagem, para além das disputas em torno da (in)visibilidade, a branquitude é conceituada como conjunto de valores, normas e capital cultural.

Os trabalhos de Giroux (1997) e Dyer (1988), ambos sobre a representação de brancos em filmes norte-americanos, e Roediger (op. cit.), que procurou desvendar as relações entre classe social e raça, demonstram como essa identidade racial está associada a determinados valores como: trabalho, civilidade, generosidade, racionalidade, cristandade, ordem, família e tradição. Seja por meio dos personagens construídos em oposição a antagonistas negros, seja por meio da caracterização do trabalhador ideal na concepção da classe operária, a branquitude é sinônimo de valores considerados positivos na cultura ocidental, valores ameaçados por membros de grupos raciais "desajustados".

Esses benefícios não materiais possibilitam que a branquitude seja encarada pelos próprios brancos como uma vantagem pública e psicológica, como uma espécie de capital cultural que passa a ser cobiçado também por pessoas que se localizam fora da branquitude, sejam elas fenotipicamente brancas ou não (GARNER, 2007, p. 51).

Nos filmes ${ }^{6}$ analisados por Dyer e Giroux a branquitude aparece como sinônimo de comportamentos socialmente adequados detectáveis em símbolos sutis, como, por exemplo, uma personagem branca que ao transgredir modelos tradicionais de sexualidade escolhe a roupa vermelha usada por sua criada negra, ou a crença de que uma professora branca pode inculcar valores civilizatórios anteriormente ausentes na experiência de seus estudantes negros e latinos; ambos revelam como a associação entre branquitude e valores sociais também se elabora por meio da construção e avaliação dos costumes e valores supostamente adotados pelos outros racializados, reforçando oposições binárias e hierarquizadas.

\footnotetext{
${ }^{6}$ Giroux analisou o filme Dangerous Minds ("Mentes Perigosas"), protagonizado por Michelle Pfeiffer. Dyer analisou diferentes produções, mas o trecho citado se refere ao filme Jezebel.
} 
Tendo em vista as três abordagens anteriormente expostas, é possível concluir que a branquitude se constrói a partir do estabelecimento de fronteiras entre a identidade branca e outras identidades raciais. Nesse quadro, a branquitude é conceituada monoliticamente como um lugar de onde emana o poder e se perdem de vista as distinções internas na categoria branco que se baseiam em processos de diferenciação não redutíveis à raça.

Tentando romper a dicotomia negro versus branco, uma quarta abordagem vem sendo desenvolvida mais recentemente, procurando analisar as fronteiras intragrupais brancas e incorporando a perspectiva de intersecções entre as principais categorias analíticas das Ciências Sociais: classe social, gênero, sexualidade e raça.

Um exemplo dessa perspectiva analítica é o trabalho de Wray (2006), que, em busca de processos de diferenciação entre brancos, desvendou os significados do termo White $\operatorname{trash}^{7}$, usado pejorativamente para designar brancos pobres. Wray investigou como a emergência do termo carregou em si as concepções de homens brancos e ricos a respeito de pessoas brancas cuja pobreza ameaçava as imagens de sua suposta supremacia.

Na pesquisa de Wray, embora brancos pobres fossem considerados menos brancos que representantes da elite, eles continuavam a pertencer a esse grupo racial, mas numa espécie de brancura de segunda categoria, passível de comparação em algumas situações com o status social de negros. Ou seja, eram brancos incapazes de acessar a branquitude e as características a ela associadas (WRAY, 2006, p. 29).

Essa brancura secundária, de acordo com o autor, seria evidência da existência de fronteiras internas na branquitude que desafiariam os modos como essa identidade vem sendo teorizada, centrando seus debates nas formas dominantes de sua construção e perdendo de vista a história de um grupo relativamente grande de pessoas: os brancos pobres.

Para Wray, a branquitude seria estratificada não apenas pela classe social, mas também pelo gênero, e essa estratificação problematizaria as descrições de uma identidade racial branca homogênea e poderosa: a "afirmação de que a branquitude é um lugar fixo, ou monolítico de vantagens raciais de conforto uniforme, é insustentável do ponto de vista histórico" (WRAY, 2004, p. 354).

\footnotetext{
${ }^{7}$ Tradução literal: lixo branco, mas em ensaio publicado no Brasil o termo chave da pesquisa de Wray foi traduzido como "ralé branca". Wray (2004)
} 
Nesse sentido, Wray propõe outra definição de branquitude que não se resuma ao binômio invisibilidade/visibilidade ou a caracterizações generalizadas que apontam para o privilégio. Ela seria:

Um processo historicamente contingente e espacialmente específico, que envolve formas institucionais, culturais e discursivas de poder. Essas múltiplas formas de poder compõem uma rede de operações que se estende por múltiplos campos de experiência histórica (e contemporânea) e produz efeitos desiguais e imprevisíveis (WRAY, op. cit., p. 357 grifos do autor).

Vê-se que o autor localiza a branquitude não somente em termos históricos, mas também espaciais e não a define pela falta ou negação, tal como proposto na segunda abordagem, mas por meio de conteúdos discursivos, culturais e práticas corporificadas que não se constroem apenas em relação a negros ou imigrantes, mas em relação aos próprios brancos, produzindo efeitos diversificados de acordo com outras posições sociais ocupadas por eles.

No entanto, nas análises de Wray, a branquitude parece não abdicar do poder de excluir mencionado nas demais abordagens, uma vez que brancos pobres seriam "percebidos como anômalos [...] eles podem parecer brancos, mas há qualquer coisa de errado em sua branquitude, qualquer coisa que não é muito branca", percepção que reforça as definições da branquitude como privilégio de poucos e a marcação daqueles que não têm acesso a tais privilégios como menos brancos, ou racialmente diferentes daqueles que habitam a branquitude (WRAY, 2004, p. 342).

Assim, a identidade branca apresentaria duas fronteiras: uma externa, entre brancos e outros grupos raciais, fronteira considerada pelas três abordagens acima descritas, e outra interna, entre os próprios brancos, tal como defendido por Wray. Possivelmente as grandes divergências apontadas entre as três primeiras abordagens e a quarta se devam ao enfoque dado a uma ou outra fronteira e à ausência de análises que levem em conta, simultaneamente, os modos como a branquitude se diferencia interna e externamente.

A ideia de que existiriam brancos não tão brancos ensejou as análises centradas na condição de imigrantes no contexto norte-americano. Essas análises evidenciaram que "fenotipicamente brancos não são imediatamente aceitos como social e culturalmente brancos", indicando que raça e cor nem sempre são critérios coincidentes na definição do status racial dos sujeitos (GARNER, op. cit. p, 66, tradução minha). Porém, nesse caso, não ser branco não equivaleria a ser negro, e ser branco, por sua vez, iria além da cor da pele, 
envolvendo aspectos da cultura e valores, o que justificaria a existência de indivíduos e grupos caracterizados a meio passo (inbetween): entre a branquitude e outras identidades raciais, indivíduos que não ocupariam nem o espaço da branquitude nem o de negros ou latinos (idem).

Nesse sentido, Roediger (1991) discutiu o esforço de imigrantes italianos e irlandeses nos Estados Unidos para tornarem-se brancos, sugerindo que uma das estratégias para alcançar tal estágio foi o engajamento em atividades racistas, o que demonstra que embora não fossem automaticamente brancos, imigrantes podiam adentrar a branquitude depreciando pessoas de outros grupos raciais dos quais, acreditava-se, não faziam parte.

Tendo em vista as descrições realizadas é possível afirmar que as quatro principais abordagens dos estudos críticos da branquitude não se excluem entre si e não esgotam as maneiras pelas quais a identidade racial branca vem sendo conceituada. Em razão da diversidade de significados atribuídos à branquitude, Garner (2007) propõe que esta seja encarada menos como uma categoria bem definida e mais como uma ferramenta analítica nos estudos sobre racismo, sendo abordada de maneiras diferentes de acordo com as demandas suscitadas pelo objeto de investigação e/ou surgidas na empiria, proposição que será adotada nas análises realizadas nos capítulos posteriores deste trabalho.

Outro ponto a destacar é o fato de que todas as abordagens trazem em si uma crítica às manifestações de poder relacionadas a hierarquias raciais, o que permite entrever um projeto político: "estudos da branquitude estão profundamente engajados em produzir formas antiracistas de conhecimento e pedagogia" (AHMED, 2004). Essas formas de conhecimento e pedagogia implicam, pelo menos, dois projetos políticos envolvendo a identidade racial branca: trabalhar pela abolição da branquitude ou por sua reconstrução em bases antirracistas (WARE, 2004).

O projeto mais ousado e polêmico de abolir a branquitude se baseia na crença de que esta "foi construída a um custo indizível para a humanidade, mas também pode ser desconstruída" (WARE, op. cit., p.10). A desconstrução se justificaria pela crença na ficcionalidade da raça, que, embora tenha uma história recente de aparição, produziu efeitos sociais concretos, influenciando desigualmente a vida de pessoas brancas e de membros de outros grupos raciais. O mesmo, como visto, pode ser dito em relação ao termo branco. 
As associações negativas entre a identidade racial branca e a desigualdade racial suscitaram clamores para que brancos deixem sua branquitude de lado. Um bom exemplo encontra-se em Race Traitor - The journal of the new abolitionism ("Traidor da Raça - A revista do novo abolicionismo"), publicação editada por Noel Ignatiev e John Garvey que é guiada pelo princípio de que "traição à branquitude é lealdade à Humanidade." Para os defensores desse projeto político, abolir a raça branca significa abolir os privilégios associados à pele branca. Obviamente, não se trata da incitação para o extermínio físico de brancos.

Para além das implicações político-ideológicas de tal projeto, um dos pontos nele destacados que contribuíram para as reflexões aqui realizadas é a não sobreposição de cor e raça, ou, neste caso, de brancura e branquitude. Os defensores da extinção da branquitude acreditam que, findos os privilégios e os significados raciais associados à brancura, a identidade racial branca seria dispensável e a cor da pele de pessoas brancas seria tão relevante quanto qualquer outra de suas características físicas. Os propositores de tal projeto salientam que "sem os privilégios relacionados à branquitude, a raça branca não existiria, e a pele branca não teria maior significação social que o pé grande" (IGNATIEV, 1997, p.1, tradução minha). A branquitude, nesse sentido, é entendida menos como uma identidade cultural e mais como uma posição social.

Tal projeto não esteve isento de críticas. A primeira delas se concentrou no fato de que em sociedades em que a raça assumiu papel central, as pessoas são chamadas a classificaremse racialmente ao mesmo tempo em que são classificadas por terceiros, o que cria um dilema: "o indivíduo deve identificar-se com sua herança cultural e orgulhar-se dela, mas sendo branco deve ter consciência de seu legado na opressão" (WRAY, 2004, p.349).

Seja qual for o projeto político relacionado à branquitude - sua abolição ou sua reconstrução -, a educação é considerada uma ferramenta indispensável para sua efetivação. Por isso, diferentes pesquisas foram desenvolvidas com professores e/ou alunos brancos buscando compreender os modos como estes construíam sua identidade racial e como esta se fazia presente no ambiente escolar. Essas pesquisas evidenciaram a grande resistência de professores brancos em verem-se implicados na ideologia racista e realmente engajarem-se em projetos para superá-la (SLEETER, 1993).

Mais do que propor a solução para um problema tão complexo, as investigações que conjugam branquitude e educação revelam a necessidade de estudos mais aprofundados sobre 
as conceituações que professores de diferentes pertenças raciais elaboram a respeito da brancura. Contribuição significativa neste sentido foi dada por McIntyre (1997), que procurou investigar "como a branquitude influencia e informa as práticas de ensino, especialmente na área de educação multicultural" (p.3). Para efetivar tal investigação, a autora separou os conceitos de branquitude e identidade racial branca, tomando a primeira como sistema de dominação e privilégio e a segunda como sentimento de pertença a um grupo de herança racial. Essa separação permitiu a elaboração de críticas aos modos como a branquitude se relaciona com o racismo sem considerá-la parte inevitável da identidade de pessoas reconhecidas como brancas. A distinção entre identidade racial e a branquitude seria impensável do ponto de vista dos projetos de desconstrução anteriormente apresentados, mas abriu possibilidades para que McIntyre interrogasse a branquitude para além do paradigma identitário.

Embora a própria autora tenha chegado à conclusão de que tal divisão não se efetivava na experiência das professoras que participaram de sua investigação, levando-se em conta as indicações de que sua identidade racial estava em "inevitável conformidade com o discurso dominante eurocêntrico branco que está na base dos modos de pensar e viver de uma sociedade branca", ao conceituar a branquitude em separado da identidade dos sujeitos a autora pode se livrar da simplicidade de raciocínio que confunde o racismo, enquanto ideologia, com o racista, a pessoa que expressa tal ideologia (p.135).

O estudo de McIntyre revelou que os desafios postos à educação multicultural não se resumem à falta de informação dos professores, mas se assentam em bases mais profundas que têm a ver com concepções de branquitude, raça e cultura adotadas pelos docentes. Assumindo essa premissa, propus-me investigar como professores da educação básica construíam a ideia de ser branco, sem, no entanto, buscar as implicações dessa construção em suas práticas pedagógicas, uma vez que a metodologia adotada não propiciou o acesso direto a essas práticas, apenas às falas que remeteram a elas. Assim, considero que esta investigação se insere num campo de estudos ainda incipiente no Brasil, em que o conceito de branquitude vem sendo incorporado a pesquisas sobre educação.

Entre estudos que se dedicaram a investigar a construção da branquitude no contexto brasileiro encontrei textos das áreas de Psicologia, Ciências Sociais, Educação e História, pesquisas que descrevo brevemente a seguir. 


\subsubsection{Os estudos brasileiros sobre a branquitude}

No levantamento bibliográfico realizado no banco de teses e dissertações da Capes, sites de busca da internet e sistema de biblioteca da Universidade de São Paulo, encontrei poucos trabalhos brasileiros que tivessem incorporado a branquitude como principal categoria de análise. Mesmo utilizando outras traduções para o termo - brancura e branquidade encontrei apenas duas publicações completas em forma de livro - Dávila (2006) e a coletânea de artigos organizada por Carone e Bento (2002), quatro artigos - Bento (1999), Piza (2002a), Ribeiro (2002) e Sovik (2004) - e onze dissertações e teses, das quais apenas duas - Bento (2002) e Oliveira (2007) - indicavam em seus títulos palavras-chave e/ou resumos, os descritores utilizados na busca, ao passo que os demais estudos construíam seus objetos em torno da condição do negro ou sobre racismo e traziam considerações sobre o grupo branco de maneira secundária.

Embora esses trabalhos sejam os primeiros a incorporar a perspectiva analítica da branquitude, Oliveira (op. cit., p.27) afirma que o início dos estudos de branquitude no Brasil pode ser traçado a partir da publicação de Guerreiro Ramos "A patologia social do branco brasileiro" (1954), em que o autor avaliava o fascínio de cientistas brancos pelo problema do negro considerando-o como comprovação de que por meio da definição do negro como um “outro", esses autores se aproximavam da brancura. Ramos definia a brancura como "critério de estética social”, padrão ideológico que se contrapunha àquilo que o autor considerava um "fato": a dominância de uma "camada negra" na sociedade brasileira "nela distribuída de alto a baixo" (RAMOS, op. cit., p. 216). Dessa predominância se originaria o problema do branco brasileiro, ou sua patologia:

A minha tese é de que, nas presentes condições da sociedade brasileira, existe uma patologia social do "branco" brasileiro e, particularmente, do "branco" do "Norte" e "Nordeste". [...] Essa patologia consiste em que, no Brasil, principalmente naquelas regiões, as pessoas de pigmentação mais clara tendem a manifestar, em sua auto-avaliação estética, um protesto contra si próprias, contra a sua condição étnica objetiva. É este desequilíbrio na auto-estimação, verdadeiramente coletivo no Brasil, que considero patológico (RAMOS, 1954, pp. 221-222, grifos do autor).

A tese de Ramos pode ser interpretada de uma dupla perspectiva. A primeira delas se refere ao ineditismo que se anuncia na colocação do grupo branco em debate, prenunciando 
uma das maneiras pelas quais a branquitude foi conceituada mais de 40 anos após a publicação de seu trabalho: o branco se define favoravelmente por meio da definição depreciada que imputa a outros grupos subordinados. Além disso, ao evidenciar que a mestiçagem não impede a classificação racial como branco, o autor lança as bases para se pensar a condição social dessa identidade no Brasil. Todavia, o mesmo ponto que confere originalidade ao texto é o que o expõe a críticas. Ao propor que mestiços claros reconhecidos socialmente como brancos estariam a negar sua "condição étnica objetiva", Ramos demonstra acreditar na existência de tal condição enquanto fato objetivo e não como construção social.

Os argumentos de que, no Brasil, não existem brancos devido à intensidade da miscigenação e de que aqueles que se classificam como tal estão a sofrer um processo de autodepreciação, ignoram os aspectos sócio-históricos que embasam a definição de alguém como branco em nossa sociedade. Seria demasiado anacrônico cobrar do autor, inserido num contexto sócio-histórico de mais de cinco décadas atrás, conclusões a que chegaram estudos mais recentes. $\mathrm{O}$ que indico é que atribuir às ideias de Guerreiro Ramos o início dos estudos de branquitude brasileiros exige cautela.

Sovik (2004), que formulou críticas semelhantes ao pensamento de Ramos, salienta aquela que considera a maior contribuição do autor aos estudos atuais: a concepção de que a branquitude no Brasil "não é genética, mas uma questão de imagem” (p. 369). A autora concluiu que os veículos de comunicação são indispensáveis para a construção dessa imagem evidenciando um projeto de nação centrado na brancura. Esse projeto, efetivado também por meio da ideia de branqueamento, é o foco do livro organizado por Carone e Bento (2002), que sugere que para pensar a branquitude no Brasil é preciso atentar para a lógica que constrói o branco e a brancura como objeto de desejo para negros, projeto acompanhado de um "silêncio sobre o branco" (p. 26).

Nesse sentido, Dávila (2006) investigou como os projetos de reforma educacional propostos na primeira metade do século XX sustentavam-se nas ideias de inferioridade e superioridade racial, fazendo da escola instituição responsável por branquear a sociedade brasileira, não mais num sentido biológico anunciado na figura do mestiço, mas num sentido sociocultural por meio da inculcação de valores tidos como brancos e de projetos de saúde e instrução que tinham como cerne políticas eugênicas. Se a eugenia em sua acepção racial como aperfeiçoamento da raça por meio do controle de natalidade e políticas de extermínio - 
era projeto inviável no Brasil mestiço de início do século $\mathrm{XX}$, sua versão sanitarista e educacional ganhou espaço nos debates de democratização da escola pública: "não só professoras eram como médicas, como também a escola era um hospital" (DÁVILA, 2006) que se destinava a curar os brasileiros de seus maus-hábitos, notadamente aqueles verificados entre negros e pobres. Mais do que um diploma que representasse o nível de instrução, a escola forneceria um "diploma de brancura" - diploma of whiteness, demonstrando como a condição de branco foi pensada nos projetos de branqueamento posteriores às versões arianistas como status que poderia ser alcançado mediante o acesso à educação.

Essas investigações apontam algumas peculiaridades assumidas na definição da branquitude na sociedade brasileira, destacando tratar-se de uma identidade independente da ideia de pureza, não condicionada apenas pela aparência, mas por um conjunto de valores e práticas sociais que podem ser acessados mediante o aperfeiçoamento cultural, num processo de "ascensão para branco" prenunciado por Freyre na década de 1930. Peculiaridades que foram consideradas na proposição do objeto desta investigação.

\subsection{O Objeto}

Este estudo tem por objetivo responder à questão “o que significa ser branco?", tomando como objeto as concepções de professores da educação básica sobre a brancura, a raça e as relações raciais. Sem a intenção de propor uma resposta definitiva e generalizada à pergunta, as análises são construídas de maneira contingente de acordo com as concepções presentes nas falas de um número reduzido de sujeitos, sem qualquer pretensão de representatividade. Essas falas foram analisadas levando-se em consideração aspectos anteriormente destacados nos estudos críticos da branquitude, tanto estrangeiros quanto brasileiros, e duas ideias foram assumidas como basilares:

- $\quad$ A brancura não é homogênea, ela se constrói num duplo processo de diferenciação um interno, condicionado por subdivisões da categoria branco - e outro externo caracterizado pelas diferenças estabelecidas entre brancos e membros de outros grupos raciais. Este último processo resulta em concepções generalizadas que relacionam brancura e poder; o primeiro problematiza e/ou reforça tais relações tendo em vista que as condições de vida de pessoas brancas se constroem com base em posições sociais que não se reduzem à raça. 
- $\quad$ Dos estudos brasileiros, adotei a premissa de que, no Brasil, a brancura se projeta para além do corpo, seja este entendido a partir de critérios de pureza - ou genética -, seja como aparência. Daí ser possível a alguém considerar-se branco sem ter ascendência europeia ou cor da pele clara.

Embora tenha considerado tais ideias provenientes dos estudos críticos da branquitude na formulação do problema de pesquisa e como perspectiva analítica, não utilizo o conceito de branquitude nas análises posteriormente apresentadas. Procuro, em vez disso, refletir ao final do trabalho como essa categoria iluminou os resultados da pesquisa, adotando o pressuposto de que o conceito não é independente da situação estudada e de que sua definição advém da própria investigação.

Para consolidar essa proposta analisei textos que conjugassem raça e educação em busca de procedimentos metodológicos mais adequados à investigação. No capítulo seguinte apresento essas pesquisas, indicando as estratégias adotadas por mim, as interações estabelecidas pelos sujeitos da pesquisa e os princípios e procedimentos realizados na análise dos dados. 


\section{Sobre metodologia, técnicas e escolha dos sujeitos}

Estudos realizados no Brasil, sobretudo nas últimas décadas, demonstraram como as relações estabelecidas na escola, os conteúdos tratados e os materiais didáticos utilizados contribuíam, seja através do silêncio frente às situações de discriminação, seja por meio da veiculação de preconceito racial, para a construção de representações negativas a respeito do negro (FAZZI, 2006 e CAVALLEIRO, 2000, entre outros). Essas investigações revelaram o caráter excludente da educação brasileira e, além de contribuírem para a reflexão sobre as relações raciais no âmbito acadêmico, puderam ser usadas como ferramentas teóricas na luta dos movimentos negros pela inserção da temática racial no currículo oficial brasileiro, indicando que esses movimentos "acreditam que a escola, sobretudo a pública, exerce papel fundamental na construção de uma educação anti-racista" (GOMES, 2008, p. 69), sendo, portanto uma instituição com potencial para ressignificar a negritude e combater o racismo.

Em 2003 foi sancionada a lei 10639, que estabeleceu a obrigatoriedade do ensino da história africana e afro-brasileira no ensino fundamental e médio em escolas públicas e privadas. O dispositivo legal é uma conquista histórica atendendo a reivindicações do movimento negro e obrigando a revisão curricular para incorporar uma história até então omitida, parcialmente contada, ou ainda, contada de maneira preconceituosa.

A promulgação da lei chamou atenção para o que as pesquisas sobre relações raciais realizadas em escolas haviam comprovado empiricamente: o despreparo de muitos professores e professoras para lidar com a temática racial em seu cotidiano profissional. O silêncio foi, durante muito tempo, a principal estratégia pedagógica encontrada por docentes e outros atores envolvidos no processo de escolarização para lidar com as situações de preconceito e discriminação ocorridas na escola.

Como salienta Gomes (op.cit.), a nova lei enseja muito mais do que conteúdos a serem inseridos no rol de temas que compõem parte do currículo. Ela deve ser interpretada como uma oportunidade de revisão de práticas e discursos que embasam o racismo na escola e na sociedade.

A apreensão expressa por Valente permanece bastante atual: "de nada adianta dispor de livro didático e currículo apropriados se o professor for preconceituoso, racista, e não souber lidar adequadamente com a questão" (VALENTE, 2005 [1995], p. 63). Embora livros e currículo apropriados sejam conquistas significativas diante do quadro descrito anteriormente, 
resta a questão de qual será a formação adequada para que o docente possa abordar com êxito a temática da diversidade em sua prática pedagógica.

Cursos de aperfeiçoamento, formação continuada e extensão universitária vêm ocorrendo com o objetivo de fornecer subsídios para a efetivação de uma educação antirracista. Dias (2008), por exemplo, analisou a transformação do cotidiano profissional de professoras e auxiliares de educação infantil que participaram de um curso sobre a temática racial e deparou-se com a incorporação dos conteúdos tratados nas aulas às práticas relativas ao cuidado e valorização do corpo negro e do cabelo crespo. Muito mais do que aplicar conteúdos adquiridos no curso de formação continuada, as educadoras entrevistadas por Dias demonstraram mudanças frente a manifestações de racismo na escola, "tornando-se menos tolerantes com qualquer tipo de discriminação" (DIAS, op. cit., p. 193).

Pesquisa semelhante realizada por Schultzer (s/d) com docentes que participaram dos cursos de formação oferecidos pelo Núcleo de Estudos Afro-brasileiros (Neab) da Universidade Federal de São Carlos (UFSCar) revelou que além de modificar a prática pedagógica, as discussões foram incorporadas à vida cotidiana dos participantes, subsidiando o reconhecimento e a desconstrução do próprio preconceito, mudando seus "modos de pensar e agir" (SCHULTZER, op. cit., p. 138).

Com base nessas conclusões, decidi realizar o estudo com professores e selecioná-los entre frequentadores de um curso sobre aspectos da cultura e da história do negro no Brasil, apostando que professores expostos a tais discussões teriam ultrapassado a barreira do silêncio que durante muito tempo caracterizou a questão racial no Brasil.

Definido o campo e o perfil dos sujeitos, restava elaborar uma metodologia adequada para a coleta dos dados. Busquei-a em textos acadêmicos das áreas de Educação, Ciências Sociais e Psicologia que tivessem incorporado a raça como principal categoria analítica e fossem construídos com base em metodologias qualitativas de pesquisa. Como principais referências, encontrei os trabalhos de Tatum (1992), Sleeter (1993; 2004) e McIntyre (1997), todos eles desenvolvidos na área de Educação e buscando analisar as relações raciais da perspectiva dos estudos críticos da branquitude, a dissertação de Oliveira (2007) e a tese de Jupp (2006), a primeira na área de Psicologia e a segunda em Ciências Sociais, também sobre branquitude. Esses trabalhos traziam detalhadas descrições da metodologia adotada e das técnicas empregadas em seus estudos, alguns com anexos de roteiros de entrevista e de 
observação que foram de grande valia na formulação de meus instrumentos de coleta de dados.

Os três primeiros trabalhos citados têm em comum a utilização de algumas técnicas peculiares à etnografia (GEERTZ, 1989 [1973]), como a observação participante e entrevistas. Tatum (1992), professora norte-americana que ministrava disciplina sobre relações raciais havia dez anos, investigou o processo de construção da identidade racial de alunos negros e brancos dos cursos de Psicologia, e construiu sua metodologia de pesquisa fazendo uso de diários pessoais de seus alunos (cadernos destinados a registrar as impressões causadas pela discussão). A autora ressaltou que a possibilidade de mudança na identidade racial de participantes desse tipo de discussão ocorre apenas quando as aulas são organizadas no período de um semestre letivo ou mais, possibilitando maior tempo para autorreflexão dos participantes.

Sleeter (1993) realizou pesquisa em curso sobre multiculturalismo organizado e coordenado por ela, com duração de 14 sessões de período integral, analisando produções escritas, entrevistas semi-estruturadas individuais e registros da participação dos alunos nas discussões. Já McIntyre, orientanda de Sleeter durante pesquisa de doutorado, desenvolveu projeto adotando a pesquisa participante como principal estratégia metodológica, com o objetivo de modificar as concepções dos entrevistados por meio do engajamento nas discussões e, não somente, de coletar dados empíricos. A pesquisadora utilizou como material de análise registros das sessões de discussão grupal, materiais elaborados pelas participantes, entrevistas individuais e coletivas. O estudo de McIntyre trazia como anexo os roteiros das entrevistas semi-estruturadas, partes do diário de campo da autora, modelos de análise dos dados - categorização e subcategorização das falas e anotações -, códigos utilizados na transcrição de conversas e gravações, ilustrando ricamente os instrumentos de coleta e análise de dados.

Entre as estratégias descritas acima, escolhi três técnicas para compor a metodologia da pesquisa ora apresentada: a observação participante, questionários e entrevista semiestruturada. Técnicas que discuto a seguir. 


\subsection{0 curso e as observações de campo}

Um curso longo o bastante para se encaixar na premissa de Tatum, acima exposta, foi proposto por uma universidade em São Paulo, com duração de julho a novembro de 2007, enfocando a vida do negro no Brasil e os problemas que se configuravam em entraves para sua efetiva inserção social.

Com o projeto em mãos, agendei um encontro com o organizador do curso para discutir a possibilidade de realização das observações participantes. No dia marcado ele não pôde me receber e mandou que uma de suas secretárias o fizesse. Bárbara ${ }^{8}$ perguntou quais eram meus objetivos. Falei pouco sobre o projeto, salientei apenas que gostaria de realizar um estudo baseado em observações durante as aulas do curso e distribuir questionários aos participantes. Fiquei aguardando resposta durante um mês e quando apareci no dia marcado para o início das aulas, a secretária havia lido o projeto e me disse que não encontraria ali o que estava procurando. Argumentei que o curso de formação de professores estava de acordo com as indicações de meu referencial teórico e ela me passou o cronograma com os temas, aos quais já havia tido acesso, e me mostrou quais aulas seriam mais apropriadas para minha investigação, sugerindo apenas três das quinze aulas programadas. Tentei explicar-lhe um dos pressupostos básicos da etnografia: a imersão no universo pesquisado durante o maior tempo possível, na tentativa de situar-me em campo (GEERTZ, 1995, p. 23), mas, obviamente, foi em vão. Quando entendi que não ia adiantar argumentar com Bárbara decidi eu mesma ir falar com o organizador do curso, que prontamente atendeu minha solicitação.

Essa entrada meio acidentada em campo me custou alguns constrangimentos. Como tinha desobedecido à recomendação da secretária, responsável pelos aspectos mais burocráticos do curso, como informes, listas de chamada e controle dos tempos de apresentação, e não pude conversar com o coordenador de maneira adequada solicitando alguns momentos de contato com o grupo a ser investigado, comecei as observações em campo sem me apresentar, e os sujeitos centrais da pesquisa não foram informados de minhas intenções. Só na décima aula consegui distribuir os questionários e falar um pouco sobre a pesquisa para todos os participantes enquanto a palestrante montava a aparelhagem de data show. Por outro lado, essa condição de anonimato me proporcionou momentos de inserção

\footnotetext{
${ }^{8}$ De modo a assegurar o anonimato dos participantes da pesquisa todos os nomes utilizados ao longo do texto são fictícios.
} 
diferenciados. Nas conversas de corredor, nos trabalhos em grupo, nos intervalos, pude conhecer melhor os professores e professoras e contar-lhes sobre o estudo que estava realizando.

Embora o curso apresentasse as características que procurava, a observação participante foi pouco utilizada. Porém, considero que algumas formulações feitas pelos docentes em entrevista se deveram ao contexto em que foram selecionados. Descrevo brevemente o campo em que parte da pesquisa foi efetivada, apontando as dificuldades que acabaram por levar-me a focar as análises nos questionários e entrevistas semiestruturadas.

O curso que configurou campo desta pesquisa vem sendo realizado semestralmente desde 2002, ou seja, antes da sanção da lei 10639/2003. A iniciativa insere-se no quadro anteriormente descrito de lutas sociais pela revalorização da negritude e tem como objetivo:

A capacitação dos professores, das redes pública e particular de ensino, no aprendizado dos aspectos da cultura e da história do negro no Brasil, propiciando acesso ao material de apoio e didático para ser utilizado em sala de aula, embasados nos conhecimentos apreendidos em cada temática que, certamente, serão de utilidade prática ${ }^{9}$.

Para alcançar tal objetivo, foram ministradas aulas expositivas, feitas indicações de leituras de artigos científicos, análise de textos literários e filmes. $\mathrm{O}$ enfoque das discussões era a presença do negro na cultura e na história brasileiras.

Durante os quatro meses de aula muito se falou da condição de ser negro em nossa sociedade. As aulas foram organizadas em torno de doze temas: "A escravidão e tráfico na África em comparação com a escravidão no Brasil”; "Estratégias de resistência à escravização - a atuação da imprensa negra"; "O movimento negro"; "Aspectos da cultura negra no Brasil"; "Discriminação racial e características do racismo brasileiro"; "O negro e a educação"; "O negro no mercado de trabalho"; "Branquitude e mídia brasileira"; "O negro e a saúde questões específicas da mulher negra"; "Multiculturalismo e identidade nacional e negra"; "Ações afirmativas no Brasil".

\footnotetext{
${ }^{9}$ Informação obtida no site de divulgação do curso cujo endereço na internet não será divulgado tendo em vista o anonimato dos participantes da pesquisa.
} 
Como é possível constatar, os debates estavam centrados na figura do negro desde sua escravização até os problemas atuais de inserção e de acesso a serviços sociais como saúde e educação. Exceção a esse quadro foi apresentada na aula a respeito da mídia, em que foi proposta a leitura de artigos científicos sobre a branquitude (SOVIK, 2004 e BARBOSA, s/d) e as maneiras como ela se apresenta em diferentes veículos de comunicação, mas a aula centrou-se na representação de negros em telenovelas. Em todas as aulas - desenvolvidas no formato de palestras com a participação de diferentes estudiosos, especialistas nas temáticas abordadas em cada encontro -, o grupo branco foi mencionado de modo secundário. Estava presente nas falas sobre escravização, na figura do colonizador português, como representante de uma cultura dominante, nos debates sobre multiculturalismo, e nas estatísticas referentes aos indicadores sociais diversos para negros e brancos, interpretados da perspectiva da desvantagem negra e não do privilégio branco.

Se o curso escolhido para configurar o campo de minha pesquisa atendia os requisitos referentes à duração e, parcialmente, quanto ao teor da discussão, já que poucas vezes a dimensão relacional foi mencionada, a dinâmica das aulas dificultou sobremaneira a apreensão e interpretação de ações e comportamentos dos participantes. Os estudos realizados em cursos sobre relações raciais e racismo, citados no item anterior, descreviam ricamente a participação dos alunos e os desconfortos suscitados pelas discussões empreendidas. Mais do que as atitudes de professores e palestrantes, ou o conteúdo das exposições, as observações centravam-se nos participantes como sujeitos da pesquisa. Já o curso observado por mim impossibilitou a mesma riqueza de detalhes.

Um primeiro obstáculo deveu-se ao número de participantes. No semestre estudado, foram oferecidas 80 vagas para professores de educação básica e interessados em geral, mas a procura superou o número de vagas e, além das 80 pessoas regularmente matriculadas, um grande número de ouvintes participou das discussões. Esse número de participantes e a organização didática das aulas, privilegiando a palestra em vez da discussão, não permitiam que todos falassem e não dava espaço para declarações mais intimistas que demonstrassem as concepções dos participantes sobre as relações raciais em nossa sociedade.

Essa realidade modificou um pouco os contornos da pesquisa. Esforçando-me para não permitir que minha observação participante se transformasse em participação observante (DURHAM, 1986), decidi aproximar-me das pessoas nos momentos de intervalo e escolher 
alguns indivíduos para observações mais atentas durante as aulas e para a realização posterior de entrevistas. Essa opção me levou a focar o olhar em dez pessoas que achavam maneiras de burlar a ordem estabelecida nas aulas e freqüentemente emitiam opiniões tanto a respeito dos assuntos tratados nas palestras quanto a aspectos de sua prática profissional que acreditavam ser antirracista. Aproximei-me desses docentes nos momentos de intervalo, tomei nota de suas poucas participações nas discussões e convidei-os para serem entrevistados. As 45 horas de observação em campo (as aulas e intervalos), juntamente com as informações obtidas nos questionários, possibilitaram algumas reflexões preliminares sobre os participantes e direcionaram a escolha das pessoas posteriormente entrevistadas.

Desse modo, os principais materiais empíricos que serviram de base às reflexões e análises realizadas ao longo desta dissertação foram os questionários e as entrevistas. Mas considero que as respostas dadas em entrevistas estavam embasadas, entre outros elementos, nas discussões efetivadas no curso, o que em alguns casos só foi possível perceber em razão das aulas assistidas. Essa influência foi explicitamente mencionada em algumas passagens, como exemplificam os excertos abaixo:

Mas tendo uma visão de hoje eu posso falar que é preconceito, era... Todo mundo aceitava aquilo, é como o professor outro dia na outra aula dizia, naturalizou. (André)

Hoje mesmo eu estava vendo um texto do professor Kabengele, tava vendo que não adianta você mobilizar em prol do racismo, pra acabar com o racismo, mobilização você faz... O negócio é uma tomada de consciência. A partir do momento em que uma escola inteirinha se mobiliza, porque nem isso a escola faz, nem isso, nenhuma escola admite, fica na questão se tem ou não tem racismo. (Samuel)

Outras passagens dos depoimentos indicavam a mesma influência, porém não explicitamente. As discussões sobre o negro como categoria política e não somente fenotípica embasaram, por exemplo, escolhas de termos como afrodescendente por parte de professores entrevistados. Estas e outras influências serão retomadas na discussão dos resultados da pesquisa, em que procuro evidenciar as falas cujo teor sugeria a utilização dos conteúdos das palestras. 


\subsubsection{Os questionários}

Os questionários foram elaborados com o propósito de facilitar a caracterização dos sujeitos. Traziam questões fechadas sobre sexo, grau de escolaridade dos pais, origem regional, formação escolar e renda. Além dessas, encontravam-se algumas perguntas abertas sobre classificação racial e de cor e a respeito dos motivos pessoais e/ou profissionais que suscitaram a freqüência ao curso.

Como havia proposto fazer entrevistas com professores autoclassificados negros e brancos, foi necessário solicitar a classificação racial dos participantes do curso. Para tanto, elaborei três perguntas, duas abertas, nas quais os sujeitos puderam se classificar livremente de acordo com a percepção que tinham de sua cor e de sua raça, e outra direcionada, considerando as categorias utilizadas pelo IBGE. O objetivo da pergunta aberta foi confrontar as categorias de coleta de dados usadas pelo IBGE às categorias utilizadas pelos sujeitos para se autoclassificarem.

A opção pelas duas perguntas refletiu também o respeito à construção que os sujeitos da pesquisa faziam de sua pertença racial, porém, sem perder de vista as categorias de classificação racial que têm sido amplamente usadas por pesquisadores brasileiros, possibilitando, desse modo, o diálogo entre a pesquisa proposta e outros estudos já realizados. Essa opção, no entanto, nem sempre foi interpretada como sinal de respeito à classificação dos sujeitos. O simples fato de perguntar a raça e a cor dos participantes suscitou críticas diretas e indiretas à pergunta por parte de alguns respondentes. Numa delas, uma das participantes se classificou como negra nos itens raça e cor, nas perguntas abertas, assinalando a categoria parda, na pergunta fechada, escrevendo ao lado: "já que não há outra opção", demonstrando seu descontentamento em se autoatribuir uma cor, e marcando seu pertencimento em bases raciais por meio do uso da expressão negro.

Como é possível constatar nos questionários anexados (anexo B), as questões abertas sobre raça foram dispostas logo no início do material, e a questão fechada estava no final, em páginas diferentes, de modo que as categorias de classificação múltipla usadas pelo IBGE não influenciassem diretamente a escolha dos respondentes e possibilitassem a eles mesmos confrontarem suas escolhas às categorias fechadas. Esse recurso evidenciou, como se verá 
adiante, a coincidência, na quase totalidade dos casos, entre as categorias oficiais de classificação racial e as escolhas individuais.

A seleção dos entrevistados se fez mediante uma primeira análise dos questionários visando à sua diversificação racial e sexual. Além disso, procurei priorizar aquelas pessoas com as quais havia estabelecido contato anterior nos intervalos do curso. Com a desistência de um dos professores anteriormente escolhidos para participarem da etapa seguinte da pesquisa, a escolha de Sara, com quem não havia tido contato direto durante as aulas observadas, se deu mediante indicação de uma amiga que freqüentara o curso em questão

Os dez professores entrevistados apresentavam o seguinte perfil socioeconômico: 
Quadro 2.1 Dados socioeconômicos

\begin{tabular}{|c|c|c|c|c|c|c|c|}
\hline & \multirow[t]{2}{*}{ Idade } & \multirow{2}{*}{$\begin{array}{l}\text { Cor } \\
\text { autoatribuída/ } \\
\text { IBGE }\end{array}$} & \multirow[t]{2}{*}{ Naturalidade } & \multicolumn{2}{|c|}{ Escolarização dos pais } & \multirow{2}{*}{$\begin{array}{l}\text { Formação } \\
\text { superior }\end{array}$} & \multirow[t]{2}{*}{ Renda mensal } \\
\hline & & & & mãe & Pai & & \\
\hline Cláudio & 42 & Negra/preta & SP & E.M & E.F. & $\begin{array}{c}\text { Pedagogia e } \\
\text { Educação Física/ } \\
\text { Mestrado em } \\
\text { Educação }\end{array}$ & + 7 S.M. \\
\hline Carolina & 35 & Negra/preta & SP & E.F. & E.F. & História & $\begin{array}{l}\text { Entre } 3 \text { e } 4 \\
\text { S.M. }\end{array}$ \\
\hline Laura & & Preta/ preta & SP & $1^{\circ}$ ciclo do E.F & $1^{\circ}$ ciclo do E.F & Pedagogia & $\mathrm{X}$ \\
\hline Roberto & 42 & Negra/preta & $\mathrm{BA}$ & $1^{\circ}$ ciclo do E.F. & $1^{\circ}$ ciclo do E.F & $\begin{array}{c}\text { Graduação e Mestrado } \\
\text { em Filosofia }\end{array}$ & $\begin{array}{l}\text { Entre } 3 \text { e } 4 \\
\text { S.M. }\end{array}$ \\
\hline Sandra & 37 & Parda/preta & SP & $1^{\circ}$ ciclo do E.F. & $1^{\circ}$ ciclo do E.F & $\begin{array}{l}\text { Pedagogia e } \\
\text { História }\end{array}$ & +7 S.M \\
\hline Samuel & 48 & Branca/branca & SP & $1^{\circ}$ ciclo do E.F & E.F & História & $\begin{array}{l}\text { Entre } 4 \text { e } 5 \\
\text { S.M }\end{array}$ \\
\hline Vitória & 60 & Branca/branca & SP & $1^{\circ}$ ciclo do E.F & $1^{\circ}$ ciclo do E.F & História & +7 S.M \\
\hline Marcio & 43 & Branca/branca & SP & $1^{\circ}$ ciclo do E.F & $1^{\circ}$ ciclo do E.F & História & $\mathrm{X}$ \\
\hline André & 32 & Branca/ X & $\mathrm{BA}$ & Alfabetizado & Alfabetizado & História & $\begin{array}{l}\text { Entre } 3 \text { e } 4 \\
\text { S.M. }\end{array}$ \\
\hline Sara & & $\mathrm{X} /$ parda & $\mathrm{PE}$ & $1^{\circ}$ ciclo do E.F & Não sabia informar & Ciências Sociais & $\mathrm{X}$ \\
\hline
\end{tabular}

Siglas: E.F - Ensino Fundamental

E.M - Ensino Médio

S.M - Salário Mínimo 
Como é possível verificar, sete dos dez entrevistados eram originários do Estado de São Paulo: Márcio, Sandra, Samuel, Laura, Carolina, Cláudio e Vitória. Entre estes, Carolina mudou-se para a Bahia e foi criada por seu avô e avó maternos até a juventude, quando iniciou uma trajetória de diferentes migrações entre as regiões Centro-oeste, Sudeste e Nordeste. Outros três nasceram e viveram sua infância na região Nordeste, mais especificamente em Pernambuco - Sara - e na Bahia - Roberto e André.

Todos os professores haviam completado o ensino superior, sendo que dois deles, Sandra e Cláudio, eram graduados em dois cursos, dados que indicam mobilidade ascendente em relação à família de origem, ao menos no que diz respeito à escolaridade, uma vez que todos eram provenientes de famílias pouco escolarizadas.

Chama atenção também a proximidade entre as idades de mulheres negras, todas variando entre 34 e 37 anos. Homens, brancos e negros, também apresentavam idades próximas entre 42 e 48 anos. Com exceção de André, que à época da entrevista estava com 32 anos, e Vitória, com 60 anos, a única mulher branca, os entrevistados estavam divididos em dois grupos etários, o que possivelmente marcou algumas semelhanças nos depoimentos, principalmente em relação à seletividade para o ingresso e permanência na escola, relatados por homens negros e brancos.

Três docentes declararam receber mais de sete salários mínimos. Vitória e Sandra esclareceram que se tratava da soma de duas rendas: no caso da primeira, a aposentadoria e o salário como professora da rede estadual e, no de Sandra, remunerações relativas tanto ao trabalho como vendedora interna numa empresa de médio porte quanto ao exercício da docência em escola municipal. Cláudio também era professor em dois cargos públicos. Os demais possuíam remuneração entre três e quatro salários mínimos - Carolina e Roberto e quatro e cinco salários mínimos - André e Samuel. Saliente-se que como os questionários não traziam questões a respeito da renda familiar per capta, condições de moradia ou acesso a serviços sociais etc., não há como detalhar melhor sua situação socioeconômica. As informações sobre esse aspecto serão tratadas na segunda parte do estudo e basearam-se nas entrevistas.

Utilizei a cor autoatribuída nos questionários para selecionar um grupo heterogêneo em termos raciais para participar da entrevista, considerando negros aqueles que se declararam negros, pretos ou pardos e brancos aqueles que assim se declararam na parte fechada do questionário. Entretanto, a classificação racial não se manteve a mesma para 
alguns sujeitos ao longo do processo de pesquisa e essas classificações serão mais bem discutidas no capítulo três.

\subsubsection{As entrevistas}

Tendo em vista a exiguidade de investigações centradas no branco, uma primeira apreensão referia-se à formulação de perguntas adequadas para que as entrevistas me permitissem efetivar o estudo proposto e que fossem elaboradas do mesmo modo para indivíduos classificados racialmente de maneiras diversas, já que se tratava de um único objetivo de pesquisa. Tal apreensão se justificava pelas dificuldades encontradas na realização da observação participante, que fornecera pouquíssimos dados empíricos, e por minha inexperiência em conduzir investigações acerca do grupo branco.

Os roteiros de entrevista semiestruturada de McIntyre (1995), Oliveira (2007) e Jupp (2006), retiradas as perguntas específicas de cada investigação, forneceram as primeiras indicações para a elaboração de meu roteiro. Essas três pesquisas construíam blocos de perguntas relacionados a diferentes fases da vida dos sujeitos: infância, juventude e vida adulta, privilegiando temas como o contato com pessoas de grupos raciais diferentes daqueles em que os entrevistados se classificaram, a vida escolar, familiar e o convívio com vizinhos, experiências com racismo, preconceito e/ou discriminação. O trabalho de McIntyre, realizado com professores, também trazia questões sobre os motivos que condicionaram a escolha da profissão, o contato com alunos diversos e o trabalho com multiculturalismo.

Baseando-me nesse material, construí um roteiro semiestruturado divido em três eixos: o primeiro deles, centrado nas memórias da infância, continha questões sobre origem regional, composição da família em termos socioeconômicos e raciais, a respeito de amigos e suas características. O segundo, centrado na vida escolar, apresentava perguntas sobre desempenho, relações instituídas, conteúdos e materiais escolares e diversidade racial. O terceiro, sobre formação e atuação docente, abordava o cotidiano da profissão, o contato com discussões sobre relações raciais, o trabalho com a diversidade racial e o convívio com alunos racialmente diversos.

Nesses três eixos, duas perguntas se repetiam: "Presenciou discriminação racial nesse espaço ou contexto? Qual a sua reação?” e "O que significa ser branco?". O roteiro semiestruturado permitiu que se mantivesse a entrevista em tom de conversa informal, ao mesmo tempo em que possibilitou a obtenção de dados comparáveis entre as várias entrevistas realizadas. 
Com as entrevistas transcritas e seguindo recomendação dada em meu exame de qualificação, retomei o contato com os sujeitos da pesquisa solicitando a correção das mesmas e a assinatura do termo de consentimento livre e esclarecido para que pudesse utilizar os depoimentos na elaboração desta dissertação (termo no anexo C).

Escolher entrevistas semiestruturadas como principal técnica de coleta de dados levou-me a ponderar sobre o peso de minha pertença racial na relação de pesquisa, já que há predominância de pesquisadores brancos à frente de estudos sobre brancos, no contexto norte-americano e europeu (WARE, 2002). Essas ponderações, assim como as possíveis interferências de minha pertença racial nas respostas obtidas, serão analisadas no item subseqüente.

\subsection{As subjetividades em contato na pesquisa}

A constatação de que brancos configuravam a maioria dos pesquisadores da branquitude suscitou inicialmente a dúvida se a paridade racial entre entrevistadora e entrevistados seria condição indispensável para a obtenção de respostas satisfatórias para a construção de material empírico coerente com os objetivos da pesquisa. Tais inquietações foram confirmadas por autores brasileiros e norte-americanos que tendem a encarar as pesquisas sobre branquitude e negritude como territórios racialmente divididos, além de serem mencionadas em meu exame de qualificação.

Piza (2002a), por exemplo, ao discutir a imprevisibilidade das respostas que encontraria ao estudar a vida de mulheres brancas, afirma:

Sabe-se que as entrevistas sobre assuntos raciais feitas por pesquisadores da mesma cor/raça do pesquisado apresentam maior índice de respostas não evasivas, o que justifica, metodologicamente, a paridade racial como estratégia de pesquisa em relações raciais (p. 59, grifos meus).

Conquanto não tenha encontrado referências teóricas que sustentem a conclusão de Piza em nenhum dos trabalhos sobre relações raciais consultados, optei por encará-la menos como uma discussão a respeito de quem é legítimo para efetivar pesquisas com sujeitos brancos ou negros, tendo em vista que a própria autora salienta a quase exclusividade de pesquisadores brancos em pesquisas sobre o negro até a década de 1980, e mais como desafio para compreender a pesquisa como resultado de uma relação em que: 
[...] a raça, o sexo, a idade e outras características do entrevistador podem influenciar o tipo de relação estabelecida. É importante que [o pesquisador] seja sensível aos efeitos que as suas características pessoais possam ter numa entrevista. Todavia, é raro que estas sejam tão pronunciadas que o desqualifiquem (BOGDAN, 1994, p.138).

Como propõe Bogdan, as características do entrevistador não necessariamente invalidam as respostas obtidas em entrevista, mas exigem atenção aos possíveis efeitos da relação nas respostas obtidas, tendo em vista que elas foram elaboradas num contexto específico e para um interlocutor específico.

Vale lembrar que as dificuldades para estabelecer diálogo entre pesquisador e sujeitos de pesquisa não são exclusivas das situações em que eles pertencem a grupos raciais diferentes. Frankenberg (1993), pesquisadora branca, recebeu uma série de respostas evasivas nas quais as entrevistadas brancas diziam não se lembrar de determinadas situações ou tentavam usar um discurso politicamente correto, sintetizado na premissa "todos somos iguais", além de ser encarada como extremista racial e representante da supremacia branca nos primeiros contatos com participantes em potencial, evidenciando que mesmo em pesquisas nas quais raça e sexo de pesquisado e pesquisador coincidem, não há garantia de ausência de respostas evasivas. Para superar esses obstáculos, a autora desenvolveu uma metodologia caracterizada por ela como "branco no branco"10 (op.cit. p. 23, tradução minha), método em que utilizou suas próprias experiências enquanto mulher branca, também exposta ao racismo e privilegiada por ele, como recurso para criar uma atmosfera de cumplicidade entre pesquisadora e entrevistadas.

As dificuldades encontradas por Frankenberg recolocam a questão da neutralidade científica e indicam que independentemente da semelhança de sexo, idade, cor ou outra característica que aproxime física ou socialmente pesquisador e pesquisado, tanto as informações obtidas quanto as análises posteriormente desenvolvidas são sempre "situadas", dependentes dos diferentes lugares sociais e identidades construídas pelo investigador (HARAWAY, 1995).

Em se tratando de pesquisadores negros, as dúvidas quanto à objetividade de suas análises não são novas. Carneiro (2005) abordou o assunto em sua tese de doutorado e em diferentes palestras a respeito da produção intelectual negra. bell hooks, já em 1995, refletia sobre a questão:

\footnotetext{
${ }^{10}$ Cabe ressaltar que tal recurso metodológico não era possível no desenvolvimento de minha pesquisa tendo em vista minha pertença racial, sendo necessária a elaboração de outras estratégias para a efetivação da pesquisa que serão descritas ao longo deste capítulo.
} 
Há sempre a necessidade de demonstrar e defender a humanidade dos negros, incluindo sua habilidade e capacidade de raciocinar logicamente, pensar coletivamente e escrever lucidamente. $O$ peso desse fardo inescapável para alunos negros no meio acadêmico branco muitas vezes tem determinado o caráter da atividade intelectual negra. [...] A opção por escrever num estilo tradicional acadêmico pode levar ao isolamento. E mesmo que escrevamos pelas linhas gerais do estilo acadêmico aceito, não há nenhuma garantia de que vão respeitar nosso trabalho (p. 472, grifos meus).

Com base nas discussões sobre a impossibilidade de neutralidade científica, fiz a opção por não limitar minha atividade intelectual, me impondo o desafio de entrevistar pessoas de grupo racial diferente do meu. Em busca da escrita lúcida referida por hooks, procuro evidenciar as relações instituídas entre os sujeitos da pesquisa e a pesquisadora, tentando compreender como essas relações influenciaram as respostas que me foram dadas.

Boa parte das relações acima mencionadas foi descrita num diário, iniciado juntamente com as observações participantes. A elaboração desse diário seguiu indicação presente no apêndice do livro de Mills "A imaginação sociológica" (1969), em que o autor sugeria que sociólogos mantivessem registradas "suas experiências pessoais e as atividades profissionais", tentando juntar "o que está fazendo intelectualmente e o que está experimentando como pessoa" (p. 212). Esse diário, diferente do caderno de campo usado no registro da observação do curso, continha tanto questões relativas à pesquisa quanto sobre outros temas.

McIntyre (1995) utilizou o mesmo recurso para explorar os modos como sua subjetividade se fez presente nas sessões que coordenou e acabou por elaborar um capítulo destinado a discutir sua própria identidade racial e as influências desta nos rumos de seu trabalho. Neste capítulo ela destacou:

Eu usei minhas notas de campo e meu diário pessoal como fontes para engajar-me em minha própria autocrítica, para descrever como construí significado para a minha própria branquitude e como esses significados foram fontes de constrangimento, ou facilidades, no papel que desempenhei como pesquisadora (p. 7, tradução minha).

Destaquei do meu próprio diário as passagens que registraram os constrangimentos e facilidades de minhas interações com os sujeitos da pesquisa, tentando ilustrar como essas interações ajudaram a produzir o material empírico e as análises. Essas impressões foram, algumas vezes, diferenciadas de acordo com a classificação racial, a idade e o sexo 
dos entrevistados. Como esta pesquisa toma a raça como principal categoria de análise, decidi focalizar as relações estabelecidas tendo por base a classificação racial dos sujeitos da pesquisa. Divido, portanto, as considerações entre interações em preto e branco instituídas por mim e pelos entrevistados que se autoclassificaram como brancos - e as interações em mesmo tom - constituídas por mim e sujeitos autoclassificados negros.

\subsubsection{Interações em preto e branco}

Uma das primeiras inquietações suscitadas após a formulação do objeto da pesquisa era a de que brancos não falariam ou não responderiam confortavelmente às perguntas formuladas em entrevista, caso a pesquisadora fosse negra. Cheguei a aventar a possibilidade de que uma colega branca da pós-graduação me substituísse na coleta de dados junto a brancos, hipótese abandonada mediante os debates sobre a ausência de uma neutralidade científica nos textos norte-americanos sobre branquitude e da presença das mesmas dúvidas que me inquietavam em estudos conduzidos por brancos.

No livro de McIntyre, novamente, encontrei uma orientação preciosa para a superação dessa dúvida:

Como envolvemos pessoas brancas em conversas sobre racismo tempo suficiente para que elas possam honestamente criticá-lo? Minha resposta a esse dilema é que não existe um caminho confortável. Não há zona de conforto para pessoas brancas quando discutimos o racismo branco. Pode haver, talvez, zonas de segurança e nós podemos ser capazes de criar ambientes não ameaçadores para discutir o racismo branco, mas minha própria experiência sugere que sempre haverá momentos de desconforto que acompanham o processo (McINTYRE, 1997, p. 43, tradução e grifos meus).

Para criar essa "zona de segurança", as estratégias anteriormente apontadas para a seleção dos entrevistados - o contato nos momentos de intervalo do curso e o conhecimento prévio de algumas de suas características por meio dos questionários facilitaram uma primeira aproximação. Ao formular o convite para a entrevista, explicava os objetivos da pesquisa - até então centrados na identidade racial branca e negra - e, aceito o convite, pedia indicações de qual seria o melhor local para conversarmos, além de assegurar o anonimato das declarações. No momento da entrevista solicitava permissão para utilizar o gravador e, com o aparelho em funcionamento, repetia as informações descritas acima, esclarecendo que os dados da entrevista seriam utilizados na elaboração de dissertação de mestrado. 
Com os docentes autoclassificados brancos em questionário - Márcio, Samuel, Vitória e André - estabeleci as interações em preto e branco. Relações que ensejaram alguns constrangimentos, mas que não impediram a fala desses professores, ao contrário, suscitaram declarações bastante intimistas a respeito dos modos como eles se reconheciam ou não como brancos e como viam pessoas de outros grupos raciais. Saliento que as situações descritas como constrangimentos foram classificadas desse modo tendo em vista seus impactos sobre mim e não se constroem, portanto, a partir da perspectiva dos sujeitos. Com exceção das respostas dadas à pergunta “como se sentiu sendo entrevistado?", feita ao final das conversas, pouco se falou sobre o processo de pesquisa em si.

O único entrevistado branco não citado nas reflexões sobre os constrangimentos surgidos na entrevista foi Márcio. O depoimento dele foi coletado com a ajuda de uma colega branca da pós-graduação devido a uma falha no gravador. Enquanto eu conduzia a entrevista ela fazia o registro. Nossa conversa foi bastante descontraída e o entrevistado mostrou-se conhecedor dos estudos das relações raciais e, além disso, já havia coordenado curso de formação de professores nessa temática.

A classificação racial foi um dos primeiros assuntos que suscitou desconfortos ao longo dos depoimentos. Os docentes foram selecionados a partir dos questionários, porque haviam se declarado brancos no momento do preenchimento. Por mais que textos acadêmicos advertissem quanto à possibilidade de um mesmo sujeito classificar-se de maneiras diferentes dependendo do contexto, não pude disfarçar a surpresa ao me deparar com mudanças de classificação racial por parte de um dos entrevistados:

Pesquisadora: Você me contou situações em que você foi discriminado, $e$ quando você discriminava, você lembra?

André: Olha, eu lembro que eu reproduzia um pouco essa ideia, de quando alguém falhava, eu chamava "Oh o coquinho", acho que eu estava sendo massacrado e acabava reproduzindo o massacre era um pouco isso também. Eu sempre... Não querendo falar que eu sou... Mesmo porque eu estou na sua frente... Eu sempre respeitei todas as manifestações culturais, nunca passei por esse tipo de dificuldade, sempre gostei muito de me envolver com pessoas do movimento negro mesmo eu não sendo denominado como negro.

Pesquisadora: Mas, você se considera negro?

André: Eu me considero, só que todo mundo [...] que você fala "Ah, mas você tem cabelo liso, branco do cabelo liso”, mas meu pai era negro e eu sou negro.

André respondeu minha indagação antecipando a avaliação que possivelmente não consegui disfarçar ao formular a segunda pergunta: estava diante de uma pessoa que aos 
meus olhos correspondia exatamente à descrição atribuída a terceiros em sua fala, um branco de cabelo liso, que até então se posicionava como branco nas situações que narrava. Percebendo minha surpresa ele completou como que justificando sua autoclassificação - meu pai era negro e eu sou negro - e continuou relatando as amizades instituídas com pessoas desse grupo racial.

Demorei um pouco para entender o que acontecia e, enquanto ele falava, refletia sobre o significado daquela mudança repentina de classificação racial não apenas naquele contexto, mas para a própria pesquisa. Procurando não constrangê-lo mais do que a pergunta mal formulada já o havia feito, continuei a entrevista a partir do tema das relações de amizade que ele então descrevia.

A pergunta que deu margem à mudança na classificação racial de André foi formulada de maneira muito semelhante a todos os sujeitos da pesquisa, brancos e negros. Apenas após transcrever todas as entrevistas percebi o incômodo que a questão suscitava independentemente da pertença racial daquele que respondia: Você se lembra de situações em que você discriminava? A resposta imediata era Não ou evasivas do tipo: Não me lembro de nada disso, eu devo ter sido, não sou nenhuma santa, mas eu não me lembro, não estou me lembrando mesmo, não estou lembrando (Vitória), ou, ainda, a negação somada à alteração da classificação racial anteriormente escolhida, como se verifica no excerto do depoimento de André.

Desse modo, embora possa apenas tecer hipóteses a respeito dos motivos que condicionaram a mudança de classificação racial por parte de André, a própria situação de entrevista pode ter interferido nesse sentido. A frase mesmo porque eu estou na sua frente deixa transparecer a crença do entrevistado de que eu pudesse duvidar da declaração de que ele sempre respeitou todas as manifestações culturais. Para validar essa declaração, ele citou como exemplo seu envolvimento com pessoas do movimento negro, declarando-se pertencente a esse grupo racial frente à minha indagação.

Após a leitura do material, percebi que os entrevistados já haviam respondido indiretamente à questão, sendo sua elaboração desnecessária. Os docentes brancos, principalmente, apresentaram disposição para descrever episódios que eles mesmos classificavam como racistas. Interpretei tal disposição como indicativa de que, para esses sujeitos, o fato de avaliarem uma situação como preconceito ou discriminação racial configurava esforço por construir uma imagem antirracista, imagem não necessariamente 
irreal, mas que fora elaborada tendo em vista a relação estabelecida na entrevista. Uma fala de Samuel exemplifica:

Eu era criança, com o tempo eu fui... No colégio também eu fui sentindo isso assim, esse racismo, eu comecei a questionar isso aí. Aí eu comecei a me perceber, que eu vivia num ambiente racista, num ambiente preconceituoso, e quando você vive num ambiente preconceituoso pra você se salvar disso aí, só pelo fato de você questionar, já é uma coisa, assim, interessante.

Posso afirmar que os professores questionaram a ideologia racista em diversas passagens, e de maneira alguma correspondiam à crença de que o maior preconceito do brasileiro é o de ter preconceito. Como indicado pelo excerto do depoimento de Samuel, admitir-se num ambiente racista já era indício de uma postura que se construía em contraposição a esse ambiente, postura que se configurava numa possibilidade de salvação. Nesses termos, para afastar-se do racismo era necessário primeiro admiti-lo e em seguida criticá-lo. Postura também ensejada pela participação nas discussões do curso em que foram selecionados.

A necessidade de construção de uma imagem antirracista estava provavelmente relacionada às imagens que os docentes haviam elaborado a meu respeito, as quais posso apenas inferir, a partir das declarações. Possivelmente, para alguns docentes, eu representava uma militante do movimento negro. Mas apenas Vitória e André verbalizaram tal percepção. Ele, ao avaliar a situação de entrevista, disse: fiquei feliz por estar contribuindo de alguma forma, acho que você também está na militância.

Já num dos contatos com Vitória essa imagem veio acompanhada de algumas expectativas. Logo após o encerramento das aulas do curso, liguei confirmando a entrevista, ela desabafou durante alguns minutos, relatando situações de preconceito racial vividas pelos alunos da escola em que trabalhava e perguntou: Você não viria até aqui dar uma palestra?Precisamos de alguém do movimento negro que debata essas questões. Como naquele momento eu não havia coordenado nenhuma discussão daquele tipo, respondi que poderia indicar uma colega que já trabalhava com formação de professores há mais tempo e que teria respostas pedagógicas melhor delineadas para o problema que ela havia relatado e combinei que passaria o contato depois.

O tema surgiu novamente durante a entrevista gravada: esses movimentos negros, eu torno a dizer, esse movimento negro precisa ir pra escola, tem muito branco discutindo essa situação... A entrevistada esperava o retorno da pesquisa não em forma de seus resultados, mas uma possibilidade de abertura de diálogo entre a escola e algum 
representante do movimento negro que pudesse oferecer subsídios aos professores e diretores. Nesse segundo diálogo, já estava mais confortável para dizer a ela que eu não participava do movimento negro, embora conhecesse algumas demandas e concordasse com elas, além de colocar-me à disposição caso as expectativas não estivessem atreladas à militância, mas a aspectos pedagógicos que conhecia bem porque também era professora.

Avalio que as falas produzidas para agradar a um ouvido militante se referiam, principalmente, ao contato com a ideologia racista. Ao falar sobre ela com tanta familiaridade, os docentes indicavam que já haviam refletido sobre as questões das quais se ocupa o movimento negro e situavam-se numa posição de quem não apenas observa o problema à distância, mas estava em condições de criticá-lo. Não considero de modo algum que se tratava de declarações forjadas, mas destaco que ao selecionarem de suas trajetórias os fatos que narraram, e não outros, a escolha foi norteada pelo que esses docentes acreditavam que eu gostaria de ouvir - assim como em toda situação de entrevista.

Também fui encarada como pesquisadora. Essa imagem foi construída de modo ambíguo. Ora eu era pensada como avaliadora das respostas: não sei se disse de fato o que você queria. (André) - fala que pode também ser interpretada como comprovação do empenho por parte do docente na elaboração de um diálogo que se adequasse às minhas expectativas -, ora como pesquisadora neutra:

Eu não sei se, talvez você como entrevistadora não possa opinar, mas se você perguntar pra qualquer pessoa, mas você reparou como nas novelas está começando a aparecer mulher negra? Elas não são mais as empregadas. Já sei que uma negra fez papel principal, ontem mesmo eu estava vendo a novela das oito tinha uma negra, por mais que você discuta a condição dessa negra, em que momento, em que contexto da novela, a questão é que está aparecendo mais mulheres negras, eu acho que isso, para a criança, a criança negra, a menina negra, para os próprios negros mesmo, é uma questão, é um fator positivo [continuando a conversa sem fazer pausa para que eu pudesse responder a seu questionamento] (Samuel)

Samuel, possivelmente em virtude da crença na ideia de neutralidade do entrevistador, nem esperou que eu respondesse à questão formulada; sem pausa, ele mesmo respondeu e continuou a elaborar suas críticas à mídia, em especial às telenovelas, acreditando numa atual mudança na representação de mulheres negras.

Em outro momento fui percebida como parte de uma estrutura excludente: Vou desabafar, aqui onde nós estamos [USP] isso aqui é uma torre de marfim. Esses caras não 
saem daqui. Esses caras não têm capacidade de pegar a Avenida Cidade Jardim e ir lá pra periferia fazer uma palestra. (Samuel) A crítica à Universidade de São Paulo e aos seus pesquisadores que, do alto da torre de marfim, constroem seus objetos sobre a realidade escolar, mas são incapazes de ir até escolas da periferia, também sugere a expectativa de Samuel de que o conhecimento produzido na universidade chegue às escolas localizadas em bairros mais pobres. Expectativa que se coaduna àquela expressa por Vitória.

Analisando as intervenções nas entrevistas divididas de acordo com os grupos de cor dos sujeitos, percebi que troquei minhas impressões sobre os tópicos tratados muito mais com os sujeitos negros que com os brancos, e dentre negros, muito mais com mulheres que com homens, mesmo que elas não tivessem formulado perguntas diretas tal como Samuel. Provavelmente em virtude dessa postura, o entrevistado acreditava que como entrevistadora eu não pudesse opinar, dado o meu silêncio ao longo de nossa conversa.

O silêncio se configurou como estratégia de pesquisa "acidental" nas entrevistas com brancos, já que não havia sido intencionalmente planejado, configurando-se como resposta imediata frente a algumas falas proferidas pelas pessoas sentadas à minha frente, num momento em que qualquer reação irrefletida poderia arruinar a frágil "zona de segurança" que havia garantido que aquelas pessoas formulassem declarações, nem sempre fáceis de falar e de ouvir, sobre a questão racial em suas trajetórias de vida. Declarações que determinaram a riqueza do material analisado na segunda parte deste trabalho.

Diante de algumas falas, principalmente a respeito da sexualidade feminina, o silêncio foi a estratégia adotada por mim de modo a não constranger os entrevistados ou demonstrar meu embaraço dependendo do modo como a frase era construída. Pois, em alguns momentos, as falas elaboradas por homens brancos denotaram que eles haviam dissociado a imagem da interlocutora/pesquisadora da figura da mulher negra que os ouvia. Samuel, por exemplo, ao descrever os motivos que levariam ao namoro de brancos com negras, destacou sem acanhamento:

Todo mundo acreditava que se um cara branco tava namorando uma mulher negra era porque ela era fácil. Tinha esse estereótipo da mulher negra fácil, mais fácil do que a branca que tinha sido criada com aquela moral cristã burguesa [...] Então a ideia da mulher negra era a prostituta. 
Já para André, foi mais difícil realizar tal separação. Os trechos sobre a sexualidade feminina foram marcados por declarações envergonhadas e hesitantes:

André: As meninas brancas são preferidas quando se fala de namorinhos, as meninas negras é um olhar diferenciado, um olhar mais... Deixa-me eu ver bem a palavra, porque, às vezes eu coloco palavras...

Pesquisadora: Pode falar, não tem nome nem nada.

André [após pausa e enrubescimento]: Não, não é essa a questão, eu nem me preocupo com isso... A menina negra é aquela que o moleque fala assim: "Essa é aquela que tem que zoar, vamos só pegar".

A entrevista de André havia sido realizada após a conversa com Samuel, e, como já havia me preparado para ouvir avaliações a respeito da sexualidade feminina - que, aliás, apareceram em quase todas as entrevistas, com exceção das de Vitória e Cláudio - não esperava que as hesitações, marcadas pelas pausas, se referissem ao constrangimento por estar diante de uma mulher negra; acreditava que o docente havia se esquecido da garantia de anonimato combinada no início da entrevista, quando, na verdade, a preocupação de André era de que eu me ofendesse com o conteúdo de sua fala. Considero que a "zona de segurança" criada a partir das interações em preto e branco se deveu em grande parte à postura de não confrontar os sujeitos em suas respostas, a menos que fosse solicitada a fazê-lo.

Assumi que, diferentemente das pesquisas anteriormente citadas (McINTYRE, 1997 e SLEETER, 1993), meu papel não consistia em "modificar pontos de vista, mas antes compreender os pontos de vista dos sujeitos e as razões que os levaram a assumi-los" (BOGDAN, 1994, p. 138). Por mais que certas declarações fossem desconcertantes, não estava ali na condição de avaliadora ou debatedora.

Curiosa quanto à avaliação da situação de entrevista por parte dos docentes, perguntei, ao final, como eles se sentiram sendo entrevistados. Algumas respostas corresponderam exatamente às minhas percepções:

Olha, é a primeira vez... Senti que... Fiquei meio encabulado em alguns momentos, acho que falei tudo enrolado, mas no geral fiquei feliz por estar contribuindo de alguma forma, acho que você também está na militância, acho que como o socialismo é uma utopia eliminar totalmente, mas minimizar os preconceitos, desde gênero, etnia ou raça, se nós minimizarmos isso e se pudermos sempre enfrentar, a grande questão é nós termos a coragem de enfrentar, às vezes as coisas ocorrem até entre nós e nós achamos que pode passar. A questão nós nos posicionarmos, porque, a partir do momento que eu dito branco, me policiando, defendendo uma causa que teoricamente, teoricamente 
porque na verdade é de todos, que não é minha, nós temos a possibilidade de andar de mãos dadas e fazer uma sociedade com menos discrepância de sujeito. No Brasil, geralmente o muito rico é o branco e o sujeito pobre é o negro, eu acho que é militar mesmo pela causa. (André)

É difícil a arte de rememorar, porque a gente quase não faz esse exercício. Dessa fala tem muito... É difícil recuperar como a gente pensava naquela hora, tem muito do olhar que a gente tem hoje, tem um pouco do olhar do momento. E você busca elementos no passado, mas tem muito de sua posição de hoje frente a essas questões. (Márcio)

Eu espero ajudar e receber ajuda (Vitória).

Eu fico... Até eu gostei muito que eu vi que vocês não discutem... Vocês não ficam naquele discurso, como se diz, aqueles discursos de histérico sobre o racismo, "a minha tia foi lá no hospital, não foi aceita porque era negra" (Samuel).

Essas avaliações representam muito do que foi a relação com esses docentes e as diferenças que marcaram cada uma delas. Vitória enfatizou novamente que não se tratava apenas de uma contribuição, mas que esperava receber ajuda para reverter o quadro de preconceito racial existente na escola em que trabalhava, encarando sua participação na pesquisa como uma ajuda da qual esperava reciprocidade. A fala de Samuel, construída na terceira pessoa do plural, pareceu se referir não somente à situação de entrevista, mas ao próprio curso e às discussões efetivadas que não se construiriam a partir de um discurso histérico sobre o racismo, com exemplos de vivência de preconceito, como sugere a frase indireta, mas com discussões teoricamente embasadas, sem debates que fizessem alusão às experiências pessoais de discriminação racial.

Já André destacou em primeiro lugar o constrangimento suscitado por algumas passagens - fiquei meio encabulado em alguns momentos - além de problematizar novamente sua classificação racial por meio da expressão $e u$, dito branco, o que sugere que embora não se reconheça como branco ele é assim reconhecido por terceiros. $\mathrm{O}$ entrevistado também salientou que o enfrentamento do racismo é tão importante quanto o enfrentamento de outras formas de opressão, citando diretamente o gênero, mas se lembrando que as divisões de classe social coincidem como a raça, no Brasil. A possibilidade de participar da entrevista foi encarada como uma contribuição para minimizar esses preconceitos, tendo em vista que eliminá-los totalmente seria uma utopia. 
Márcio ilustrou bem o trabalho realizado pelos entrevistados na elaboração das memórias para responder às minhas perguntas. $\mathrm{O}$ que foi narrado por eles foi construído a partir do olhar de hoje a focalizar situações vividas, por vezes, num passado muito distante, mas que ganharam significação a partir das experiências tanto passadas quanto presentes.

Fiz parte, naquele momento, das experiências presentes. Nossa interação também deu forma a esse olhar. Considero que ao lançar uma olhada ao passado e às situações descritas, esses docentes levaram um pouco da imagem que construíram a meu respeito em busca de elementos que pudessem ser acionados para contribuírem de alguma forma com esta pesquisa. Se não criamos juntos uma "zona de conforto" ou uma metodologia "branco no branco", criamos as interações em preto e branco que permitiram o desenvolvimento de parte deste estudo.

\subsubsection{Interações em mesmo tom}

Nas interações estabelecidas com sujeitos autoclassificados negros em questionário apreendi alguns componentes de maior empatia quando comparadas às interações com brancos, anteriormente descritas. Esses componentes se referiam, principalmente, às experiências comuns de racialização e gênero, nas interações com mulheres, e à convergência de ideias e avaliações sobre o racismo na sociedade brasileira, nos contatos com homens.

Especialmente com mulheres negras, as lembranças relativas aos cuidados com o cabelo crespo e relações de namoro ensejaram a partilha de opiniões e relatos de experiências, como ilustra o excerto do depoimento de Laura:

Laura: E outra vez foi engraçado, hoje eu falo que foi engraçado, porque assim, a minha mãe alisou meu cabelo, e eu me senti o máximo [...] $O$ que aconteceu? Fui pra casa aí fui tomar banho, coloquei a touquinha e fui tomar banho [...] eu saí do banho e o que aconteceu com o vapor d'água?

Pesquisadora: O cabelo encolheu! [risos]

Laura: E o pior é que minha mãe não alisou de novo e eu não queria ir para a escola.

Pesquisadora: Já sei, não pode alisar de novo senão estraga o cabelo, alisou hoje, [agora] só daqui uma semana...

Laura: Exatamente! [risos]

Tendo vivido na infância a mesma experiência de alisamento dos cabelos que Laura rememorava, o relato transformou-se numa animada conversa sobre os processos malsucedidos de alisamento e suas conseqüências tanto para nossa percepção como 
mulheres negras quanto para nossa vida escolar. Dentre essas conseqüências estavam as queimaduras que os dentes do pente quente ${ }^{11}$ deixavam em nossas testas e orelhas, e cuja origem crianças e professores brancos não conseguiam identificar, queimaduras que se configuravam como um segredo partilhado por meninas negras, do qual ríamos naquele momento.

As considerações a respeito dos cabelos crespos estiveram presentes apenas nos depoimentos de mulheres negras. Os entrevistados brancos, homens e mulheres, e os homens negros não fizeram menção a situações como a citada por Laura, nem para se referir a experiências vividas por terceiros. Se os cabelos são "suportes simbólicos da identidade negra no Brasil" (GOMES, 2006 p. 20), nesta pesquisa esse suporte foi lembrado exclusivamente por mulheres negras, indicando que para os docentes entrevistados a importância atribuída ao cabelo se diferenciava de acordo com o sexo e a raça, provavelmente porque, para as mulheres negras, os apelos sociais que atrelam brancura e determinados padrões de beleza, como será salientado em capítulo posterior, tenham marcado seu relacionamento com seus corpos, em especial, com seus cabelos. Essas diferenças indicam que não apenas a pertença racial, mas também o sexo, influenciou a partilha de opiniões e experiências entre pesquisadora e entrevistadas.

Todavia, não considero que minha pertença racial tenha facilitado o processo de entrevista de maneira semelhante para todas as mulheres negras com as quais tive contato. Sandra identificou em episódios como os descritos acima fontes de constrangimentos e lembranças dolorosas sobre as quais ela preferiu calar: Mas eu fui educada assim: até pouco tempo atrás tinha vergonha de dizer, não que eu negasse minha negritude, mas é melhor não falar sobre isso, porque é uma coisa meio pesada. A docente começou nossa conversa negando a vivência de situações de discriminação racial e, ao longo da entrevista, algumas perguntas suscitaram memórias que ela parecia querer apagar: Olha, estou me lembrando de mais fatos! Para de mexer com esse assunto, para de mexer com esse assunto. Tais constrangimentos revelam que independentemente das características que nos aproximavam socialmente, Sandra não se sentiu à vontade para falar a respeito de sua pertença racial.

\footnotetext{
${ }^{11}$ Laura falava sobre a "chapinha" e o "pente quente", método que consistia em colocar uma chapa dupla ou um pente de ferro sobre a chama do fogão e esperar que esquentassem para, em seguida, passar sobre os cabelos que, se molhados, voltavam à característica original; versão antiga das atuais chapinhas e escovas de cabelo elétricas.
} 
Mesmo levando em conta os constrangimentos verificados no diálogo com Sandra, não considero que nas interações com negros as maiores dificuldades se devessem a tópicos relacionados diretamente à questão racial: a hierarquia pesquisadora/pesquisado foi mais explicitamente incômoda para esses sujeitos. Esse incômodo pareceu ser mais pronunciado em se tratando de docentes provenientes de instituições particulares de ensino superior, em especial os entrevistados Carolina e Cláudio, evidenciando que as hierarquias existentes entre instituições públicas e privadas de nível superior estavam manifestas na relação de pesquisa com esses sujeitos. O fato de estar vinculada à Universidade de São Paulo, mesmo na condição de aluna da pós-graduação, possivelmente suscitou a necessidade de construção de imagens que nivelassem nossa experiência de escolarização por parte dos entrevistados.

Com exceção do depoimento de Sandra, também graduada em faculdade particular, os demais entrevistados acima citados esforçaram-se por lembrar, em diferentes momentos, sua inserção no espaço acadêmico, chegando alguns a me oferecer indicações de textos, citarem autores que acreditavam que eu desconhecesse e falar longamente acerca de estudos que haviam conduzido ou estavam concluindo sobre a temática racial.

Cláudio, por exemplo, mencionou em quatro diferentes momentos de seu depoimento, a dissertação de mestrado sobre a implementação da lei 10639/2003 que então concluía e sobre um artigo que dela havia resultado:

\begin{abstract}
Estou terminando esse artigo pra entregar sexta-feira próxima, que é sobre o lugar simbólico do negro na educação. Eu não coloquei esse título, porque senão o professor não iria aceitar, mas eu estou colocando o negro na educação e a emancipação e a construção do sujeito. E daí eu estou fazendo uma ligação com os pensadores europeus, que é o Adorno e o Touraine, o Touraine na questão do sujeito e o Adorno na questão da educação crítica e o pensamento crítico e a emancipação. Então você vê, eu falei como um africano? Eu falei como um afrodescendente? Eu falei como um europeu, com uma tranquilidade "o Adorno", como se o Adorno fosse íntimo, tive que me apropriar da ideia dele, ser íntimo, Touraine também. Você conhece alguma coisa do Adorno? [Pesquisadora: Conheço] pensamento crítico, escola de Frankfurt, a questão do Holocausto...
\end{abstract}

O excerto acima é parte da extensa resposta de Cláudio à minha solicitação para que ele falasse sobre sua escolarização na infância. Assim como nessa passagem, ele conduziu boa parte da entrevista. Mesmo quando as perguntas formuladas por mim se referiam a aspectos que não diziam respeito à sua atividade de pesquisa ou sua bem- 
sucedida carreira de jogador de basquete na adolescência, essas atividades eram lembradas por ele, e algumas de minhas indagações permaneceram sem resposta.

Da mesma forma que Cláudio, outros entrevistados também se referiram às suas trajetórias de sucesso no ensino superior e às expectativas quanto ao prosseguimento dos estudos em nível de pós-graduação. Não percebi nesses momentos uma reação de insegurança frente à minha presença, mas uma afirmação de que os lugares ocupados por nós na situação de entrevista poderiam ser inversos ou o seriam num futuro próximo.

Vale salientar que constrangimentos semelhantes estiveram presentes em investigações conduzidas por outros pesquisadores da mesma instituição à qual este estudo se destina. Carvalho (2003), em estudo etnográfico realizado em escola de ensino fundamental, identificou elementos semelhantes nas interações com professores e destacou que estar vinculada à Universidade de São Paulo ensejou reações por parte dos docentes de "exterioridade, e desconfiança, mesclados à inveja, insegurança e admiração, que se traduziam seja em comportamentos de exibição [...]; seja em afirmações de superioridade da prática e da experiência sobre a teoria" (p. 211).

Já com os entrevistados graduados ou pós-graduados na Universidade de São Paulo - Laura, Sara e Roberto - as menções às suas atividades de pesquisa foram breves. Somente quando instados a falar sobre tais atividades, esses docentes se dispuseram a relatá-las. Dentre esses docentes, apenas Sara demonstrou apreensão diante da possibilidade de que esta pesquisa se destinasse à pós-graduação em Sociologia, com receio de que a crítica que formulava a respeito de um dos professores da instituição pudesse comprometê-la de alguma forma: Esse trabalho é para as Sociais? [Pesquisadora: Não, como havia dito, é para a Educação] Então posso falar. Não apenas a identidade de pesquisadora que me foi atribuída pelos docentes influenciou parte dos depoimentos, mas também as ideias construídas a respeito da própria pesquisa mostraram-se relevantes.

Cinco dos seis docentes negros entrevistados tinham grande familiaridade com pesquisas acadêmicas sobre raça, o que, atrelado às suas próprias experiências de racialização e às discussões presenciadas no curso em que foram selecionados, possivelmente conformou a percepção de que o estudo que propunha inseria-se no campo de investigações acerca da negritude e/ou do racismo. Questões do tipo: "Você tinha contato com pessoas de grupos raciais diversos?” eram respondidas com longas descrições de episódios de preconceito, dificultando a apreensão das concepções construídas pelos docentes sobre pessoas brancas que ultrapassassem a figura do opressor. Justamente devido 
aos elementos de empatia, anteriormente mencionados, algumas perguntas $\mathrm{e}$ direcionamentos da conversa deixaram de ser feitos e alguns depoimentos não continham respostas a questões que julgava centrais. No depoimento de Cláudio, por exemplo, não formulei a pergunta referente à avaliação da situação de entrevista.

Mesmo quando indagações a respeito do grupo branco entrecortavam os depoimentos de discriminação racial, a dificuldade de docentes negros para falar a respeito de brancos revelou que as considerações sobre raça foram muitas vezes entendidas como peculiares aos negros.

Pesquisadora: $O$ que significa ser branco, tanto na escola como fora dela, o que você acha que significa ser mulher branca, homem branco, se é igual para os dois se tem diferença?

Carolina: Nossa! Eu acho difícil essa sua pergunta. Primeiro porque eu não sou branca, eu não sou branca. Eu não sei como é ser branco e pra mim me imaginar branca também fica difícil te dar essa resposta, porque é um universo pra mim que, deve ser diferente, porque sempre me trataram como diferente. E assim, você imagina que deve ser... Ser branco deve ser muito bom, viver no meio de brancos deve ser também muito bom. [...] Sinceramente, eu não sei lhe falar como é ser branco, porque nunca...

Embora a resposta construída na negativa (não sei lhe falar como é ser branco) traga elementos que caracterizam o grupo racial em questão (ser branco deve ser muito bom), entre outros trechos, a reação de Carolina à pergunta foi de completa estranheza. Tendo referido a si mesma como negra, membro de um grupo racial sobre o qual tinha diversas considerações a fazer, a surpresa diante da questão revelou que até então o grupo branco e os significados atribuídos à raça branca haviam sido pouco presentes em suas reflexões acerca das desigualdades raciais ou do racismo. Essa mesma reação encontra-se no depoimento de Roberto, que ao responder à mesma indagação dirigida a Carolina salientou:

Essa é uma pergunta muito interessante, viu? É uma coisa a se pensar, que esse contrário eu não sei se eles se pensam "O que é que significa ser negro?" Não sei se alguns deles se pensam, se pensarem como negros, e eu não sei... Eu nunca refleti isso profundamente não, o que significa para o branco... Vou imaginar uma coisa, como é para um aluno branco de uma família de todo mundo branco, de origem europeia, ter um professor negro? [pausa] Também não sei.

O estranhamento fez com que Roberto tentasse imaginar-se na posição de brancos com os quais convivia. Exercício que também não teve resultados, já que após grande 
pausa o docente admitiu não saber o que pensavam alunos brancos em contato com professor negro.

Pareceu-me significativo o movimento realizado por esses docentes de tentar pensarem-se brancos para responder à pergunta "o que significa ser branco", um movimento ausente nas entrevistas coletadas junto à autoclassificados brancos quando indagados a respeito dos significados de ser negro. Docentes brancos elaboraram uma série de relatos a respeito da experiência negra, sem tentar apreendê-la da ótica dos próprios negros, mas a partir de seu próprio olhar, como brancos.

Percebendo essas diferenças, partilhei esse aspecto particular das entrevistas de docentes brancos com Carolina, buscando ilustrar que a percepção da negritude ou da condição de ser branco não necessariamente implique a vivência de uma ou outra identidade, tal como sugere a frase: Eu não sei como é ser branca e pra mim me imaginar branca também fica difícil te dar essa resposta. Logo em seqüência, acrescentei:

Pesquisadora: Quando eu faço uma pergunta pra um branco "O que você acha que significa ser negro?", ele tem um rol de coisas pra falar sobre o negro. Não necessariamente de como o branco se vê, mas de como você vê o branco.

A resposta à indagação acima trouxe elementos relacionados ao medo e ao constrangimento suscitados pela presença de pessoas brancas nos ambientes frequentados por Carolina, fala que será analisada na segunda parte deste trabalho, evidenciando que um dos significados de ser branco, para a entrevistada, se relacionava aos relatos de discriminação elaborados ao longo de seu depoimento. Esse silêncio e as dificuldades para refletir sobre a brancura podem ser interpretados tendo em vista a proliferação de debates a respeito da raça centrados nos negros e a invisibilidade por vezes conferida ao grupo branco. Foi particularmente difícil a alguns professores desvencilharem o discurso sobre raça daquele relacionado à negritude, fossem eles brancos ou negros.

Mesmo com essas dificuldades, encontrei nas experiências relatadas pelos docentes autoclassificados negros, diversas passagens que não se resumiram em respostas diretas à questão do significado de ser branco, mas que traziam considerações sobre as maneiras como os docentes negros encaravam a sociedade brasileira e as interações raciais, possibilitando, desse modo, a incorporação de seus relatos às análises desenvolvidas nos capítulos subseqüentes. 
Ao avaliarem a situação de entrevista, esses docentes destacaram o prazer de rememorar situações muitas vezes dolorosas, e de serem ouvidos com atenção:

Aí, foi uma delícia, porque, na verdade eu nunca tinha feito esse exercício da fala, e tanto que eu espero ter contemplado. Agora, uma coisa legal, que eu achei o máximo, foi essa coisa de ir falando e lembrando as coisas e ver os dois lados, eu nunca tinha feito isso, do que é que atingiu, que não atingiu, o que foi ruim, o que não foi, lembrei até o nome da professora Teresa [risos] então eu acho que eu ainda, apesar da formação, mas eu ainda continuo com mais bagagem nessa questão da vivência, do que do trabalho, mas foi um exercício muito legal. (Laura)

Eu me senti muito bem sendo entrevistado, porque essa coisa de você ser professor é tão desvalorizada, eu tenho saído das salas de aula constantemente tão mal, nada que você faz dá certo, tudo o que você faz dá errado, parece né, parece que tudo dá errado, as tentativas são diárias. Você leva uma coisa não gosta, não gosta de um filme, de uma música, tem um momento em que você não se sente muito digno. E ser entrevistado é um momento em que você é ouvido, em que alguém vai considerar suas respostas e tal. Foi legal, eu achei legal. [Pesquisadora: eu também gostei bastante] Essa última pergunta que você me fez é algo em que agora eu vou pensar, o que significa ser branco, é algo muito interessante. (Roberto)

Ah, me senti bem, falei tudo o que eu sinto, o que eu... O que se passa. Eu pensei que fosse mais complicado, que você fosse me perguntar, talvez alguma coisa assim, mais científica, na parte cientifica, na minha parte de formação, mas não, foi mais história de vida mesmo, eu nunca tinha passado por isso, já tinha lido várias, mas não tinha passado ainda por isso. Espero que seja útil pra você [Pesquisadora: com certeza] (Carolina)

Gostei. São poucas pessoas com as quais a gente pode discutir esses assuntos com profundidade, aqui no curso é o contrário. (Sandra)

É importante fazer esses estudos, mas é importante fazer esse diálogo com outras escolas. Na escola está muito ruim. A questão da qualidade de ensino está muito ruim. Pra uma criança se não tiver nenhuma coisa dessas que faça a diferença na vida dela, não vai chegar a lugar nenhum. Não vai conseguir chegar nem aonde a gente chegou porque falta oportunidade mesmo. É isso. Acho que é uma batalha. (Sara)

Assim como nas interações com docentes brancos, as avaliações dos entrevistados negros disseram muito a respeito das características do diálogo empreendido com cada sujeito.

Laura destacou que nossa conversa serviu não apenas à troca de informações relacionadas à pesquisa propriamente dita, mas se transformou em momento de reflexão sobre aspectos de nossas trajetórias de vida que puderam ter seus impactos sobre sua 
subjetividade, avaliados na ocasião de nossa conversa: o que atingiu, o que não atingiu. Memórias da construção da identidade negra que a entrevistada não havia partilhado com outras pessoas, dado o silêncio acerca de tais questões no ambiente familiar em que ela crescera.

Nesse mesmo sentido, Sandra sintetizou nossa conversa como um momento em que pôde discutir em profundidade assuntos relacionados à raça, identificando a situação de entrevista como parte do curso de formação então frequentado por ela, provavelmente em virtude de que a entrevista foi realizada na própria instituição que oferecia a formação e versava sobre alguns assuntos semelhantes àqueles tratados nas discussões das quais participávamos.

A oportunidade de ter suas reflexões ouvidas e levadas em consideração por terceiros também foi apontada por Roberto, porém o docente não se referiu a aspectos de sua pertença racial, tal como as docentes acima, e sim à desvalorização experimentada como professor da educação básica, tema mais significativo para ele, que havia participado do movimento negro durante sua graduação em Filosofia e já havia tido oportunidades de discutir a respeito das questões da entrevista.

Já Sara e Carolina destacaram a possibilidade de contribuir para esta reflexão. Esta última, acreditando que teria que responder a questões mais científicas, surpreendeu-se com o caráter menos formal de nossa conversa, desejando que as informações que me disponibilizara fossem úteis à pesquisa. Sara, por sua vez, destacou a importância de pesquisas sobre raça e educação como uma forma possível de reversão do quadro de exclusão que presenciava como professora de educação infantil, caracterizando a reversão como uma batalha da qual participávamos minimamente naquele contexto, ela cedendo informações que pudessem auxiliar a elaboração deste estudo e eu na condição de pesquisadora.

Essas interações em mesmo tom revelaram que a nossa pertença racial - minha e dos entrevistados - mais facilitou que prejudicou a relação de entrevista. Em diversas ocasiões, as opiniões acerca da sociedade brasileira ou até mesmo situações vividas por pesquisadora e entrevistados revelaram-se bastante similares, sugerindo que a semelhança de nossas cores, ou se preferível, de nosso tom de pele, também condicionou semelhanças no tom de nossas reflexões.

Além da pertença racial, outras características como sexo e escolarização também interferiram nessa relação e, em certos momentos, configuraram-se como características 
mais relevantes para o processo de entrevista que aquelas relativas à raça. Considero que com sujeitos negros, a estratégia de pesquisa "branco no branco" utilizada por Frankenberg (1993) para partilhar com os participantes da pesquisa concepções e experiências sobre a raça foi assumida por mim, obviamente em cor diferente, para criar uma atmosfera de cumplicidade com os entrevistados, garantindo a apreensão de concepções de brancura no imaginário de pessoas negras. Essas interações, bem como seus possíveis resultados sobre os depoimentos, foram consideradas nas análises do material empírico.

\subsection{Princípios e procedimentos de análise}

Em estudo sobre relações raciais na educação infantil, Cavaleiro (2000) se pergunta se os caminhos percorridos na efetivação da pesquisa seriam menos árduos fosse outra a pesquisadora, avaliando que se "fosse branca, ou ainda, um pesquisador do sexo masculino, por certo teria um "olhar" diferente sobre esse tema" (p. 39). Na construção de suas análises, ela destaca o lugar de onde fala, assim como o fazem outros pesquisadores negros dedicados ao estudo da temática racial, identificando as facilidades e dificuldades condicionadas por esse "olhar" no processo de pesquisa.

Já entre pesquisadores das relações raciais brancos, a tendência de localizarem-se racialmente é menos expressiva. Encontrei exceção a esse quadro apenas nos textos de Piza (2002) e Guimarães (2000). Este último, ao refletir sobre a questão de sua pertença racial em sua atividade de pesquisa, salientou:

De que lugar alguém como eu, sendo branco, pode escrever sobre o racismo no Brasil senão do lugar do branco? [...] Pois bem, esse lugar de branco, não sendo um lugar de descendência, nem sendo o lugar de onde os pretos fossem "outros" só podia ser o lugar da democracia racial. Pois é, venho desse lugar. De um lugar onde o "racismo" só podia ser produto da mesquinhez ou dos desvios de personalidade individuais. Onde o "preto" era objeto de pena e não de ódio, tratado como se tratam os deficientes físicos; um inferno, mas um inferno de onde podiam salvar-se através da mestiçagem, pulando para o purgatório dos "pardos", ao tempo que estes podiam aspirar, através da educação e do dinheiro, o paraíso dos brancos (GUIMARÃES, 2000a, p.1).

Piza (op. cit.) avalia que o lugar de onde falaram autores brancos a respeito das relações raciais no Brasil, incluindo parte de sua própria produção intelectual, não foi, durante muito tempo, branco, mas sim "neutro, incolor", um lugar de onde se elidiu "a própria racialidade, diante da imensa racialidade atribuída ao outro" (p.61).

Assim como esses autores discutem, eu não poderia falar de outro lugar senão o de mulher negra pesquisadora das relações raciais. A lista de identidades mobilizadas neste 
processo de reflexão possivelmente é bem mais longa, mas as avaliações e leituras das versões preliminares deste texto revelaram serem estas as identidades que influenciaram de maneira mais direta o processo de investigação, em virtude, especialmente, da incorporação da raça como principal categoria de análise.

Contudo, as considerações a respeito das interações de entrevista anteriormente discutidas permitem entrever aspecto que vai além dos "saberes localizáveis" (HARAWAY, 1995) construídos a partir dos lugares dos quais falam os pesquisadores: a relevância de atentar para o peso das relações estabelecidas na pesquisa nos resultados obtidos e nas análises realizadas. Nesse sentido, em vez de me ater a discussões a respeito de minha trajetória, acreditei ser mais profícuo atentar para os efeitos de minha presença e das relações que estabeleci com os docentes na análise do material empírico produzido, tal como propõe Carvalho (2003), incorporando também reflexões a respeito do contexto em que os professores foram selecionados.

Considerando este princípio básico de análise, as dez entrevistas foram analisadas tendo em vista os critérios implicados no próprio objetivo do estudo. Busquei, desse modo, priorizar falas que se remetessem ao grupo branco, mantendo aquelas que faziam alusão aos negros quando estas se referiam a comparações entre ambos os grupos raciais.

Iniciei pela codificação do material. Com a ajuda de minha orientadora, reli as entrevistas dividindo-as por temas e elaborando as primeiras codificações, a princípio recortando as entrevistas e fazendo arquivos separados para cada tema. Neste primeiro processo identifiquei dezessete grandes tópicos, e escolhi dentre estes aqueles que melhor se adequavam à discussão que propunha desenvolver e que pudessem ser analisados em tempo hábil tendo em vista os prazos da pós-graduação. Em cada um desses arquivos, continuei a classificar as falas de acordo com o que estava expresso nelas e com o que as leituras do material teórico já sinalizavam como importante. Algumas citações que poderiam ser utilizadas em diferentes temas foram repetidas e, como se verá, uma mesma fala foi analisada partindo-se de propósitos e perspectivas diferentes.

No arquivo "classificação racial", por exemplo, uma primeira divisão correspondeu às falas que se referiam à aparência dos sujeitos e aquelas que remetiam à origem. Foram consideradas, também as oscilações, as categorizações de terceiros e as divergências entre auto e heteroclassificação, tal como ilustrado abaixo: 


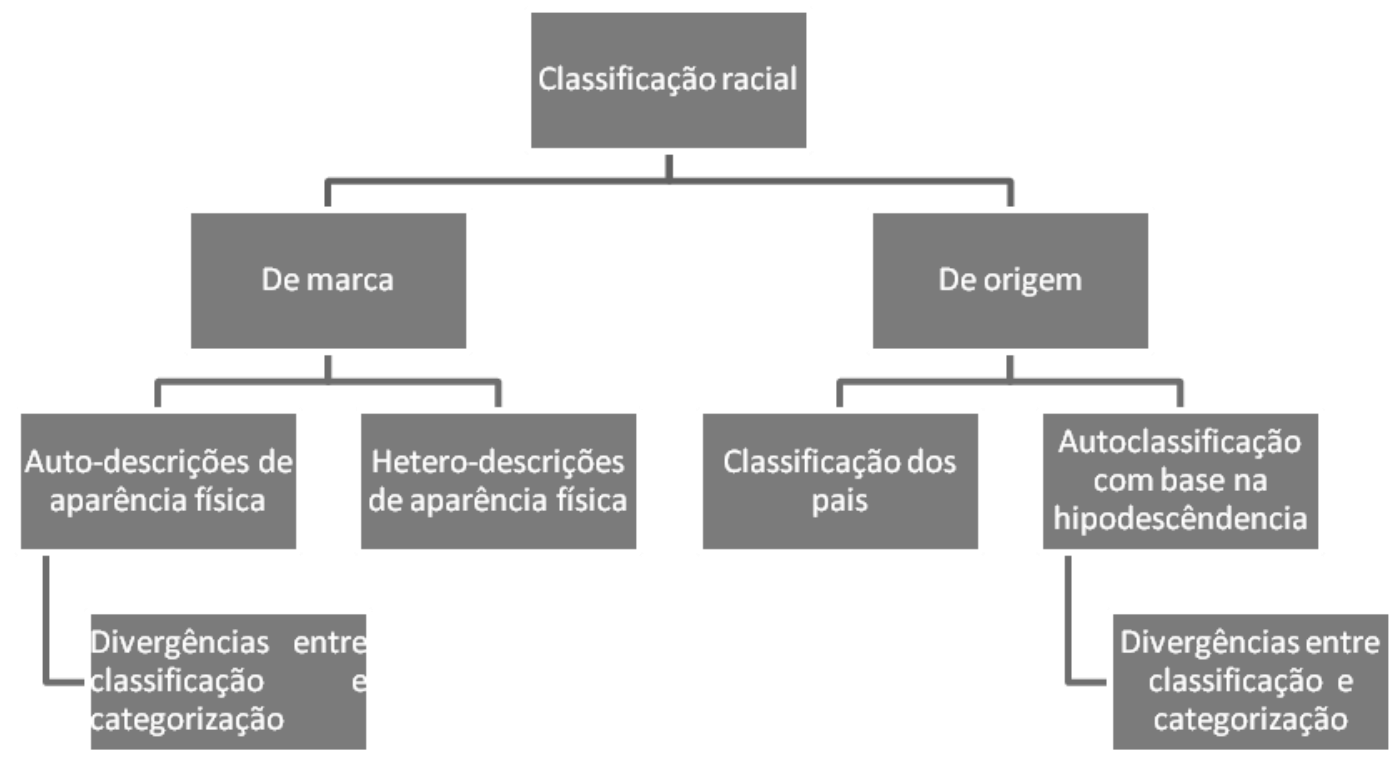

Diferentes classificações de marca e de origem expressas na fala de um mesmo sujeito foram interpretadas como oscilação de classificação racial. Outros tópicos decorrentes da análise das entrevistas e considerados neste trabalho foram:

- Associações com a brancura;

- Branqueamento;

- Situações de vantagem e desvantagem vividas por brancos;

- Situações de vantagem e desvantagem vividas por negros;

- Citações a relacionamentos inter-raciais;

- Citações ao grupo branco na escola;

- Constrangimentos da entrevista;

Em cada um desses tópicos foram feitas divisões como no organograma acima, de modo a criar subtemas que facilitassem a análise e o processo de escrita. Em todos eles considerei, como exposto anteriormente, os contextos em que os depoimentos foram coletados, ou seja, o campo da pesquisa e as interações de entrevista. Os resultados desse processo de análise estão registrados nos capítulos que se seguem. 


\section{PARTE II - SIGNIFICADOS DE SER BRANCO}




\section{Introdução}

Os "olhos" disponíveis nas ciências tecnológicas modernas acabam com qualquer ideia da visão como passiva. Esses artifícios protéticos nos mostram que todos os olhos, incluídos os nossos olhos orgânicos, são sistemas de percepção ativos, construindo traduções e modos específicos de ver, isto é, modos de vida.

Dona Haraway

Neste trabalho, ser branco apresentou, pelo menos, duas dimensões correlatas: uma parcialmente corporal e outra menos visível que denominei significados e/ou valores de ser branco. A primeira dimensão pode ser em parte associada ao fenótipo, ou seja, às características físicas, principalmente àquelas relativas à cor da pele, tipo de cabelo, formato do nariz, entre outros, cuja observação permite classificar racialmente os sujeitos como brancos. Já a segunda dimensão se associa a determinados significados e valores sociais informados pela ideologia racial (racialista ou racista) que são relacionados à brancura e só em parte dizem respeito à classificação fenotípica. Esses significados têm mais a ver com construções arbitrárias baseadas na ideia de raça.

As duas dimensões são construídas de maneira interdependente, já que a cor não é uma categoria objetiva que pode ser prontamente percebida no ato de ver. Isso seria possível apenas se "ver" fosse um processo neutro, mero resultado da captação sensorial da informação supostamente óbvia de que as pessoas têm diferentes cores de pele. Se os olhos são "sistemas de percepção ativos" que constroem modos específicos de ver (HARAWAY, 1995, p.22), as diferenças que vemos são também construídas segundo relações que pouco, ou nada, têm a ver com uma realidade objetiva preexistente à espera de ser captada por nossa visão. Pelo contrário,

[...] não há nada espontaneamente visível na cor da pele, no formato do nariz, na espessura dos lábios ou dos cabelos, ou mais fácil de ser discriminado nesses traços do que em outros, como o tamanho dos pés, a altura, a cor dos olhos ou a largura dos ombros. Tais traços só têm significados no interior de uma ideologia preexistente (para ser preciso: de uma ideologia que cria os fatos, ao relacioná-los uns com os outros), e apenas por causa disso funcionam como critérios e marcas classificatórios (GUIMARÃES, 1997, p. 47).

Nesse sentido, a brancura que se verifica nos corpos daqueles socialmente reconhecidos como brancos tem sentidos que ultrapassam a pigmentação. Para discutir esse problema destaquei das entrevistas os trechos que faziam menção ao grupo branco e que 
não se resumiam à descrição de sua aparência. Tais trechos foram classificados em quatro grandes grupos cuja análise se desenvolveu em capítulos separados.

No primeiro grupo, no qual procurei concentrar as falas que se referiam à classificação racial dos sujeitos da pesquisa, a maior parte da análise foi baseada no modelo teórico desenvolvido por Oracy Nogueira (2007 [1954]), que divide a classificação racial de acordo com critérios fenotípicos - marca - ou de ascendência - origem -, relacionados à brancura localizada no corpo dos sujeitos, seja em sua aparência física, seja inscrita nos genes e passada de geração em geração.

No segundo grupo estão reunidas as falas que remeteram a características associadas à brancura para além da aparência física ou da ascendência, demonstrando que ser branco é também uma condição construída socialmente com base na ideologia racial. Esses sentidos sociais da brancura se diversificam em função de fatores que não se restringem à raça, incluindo também o gênero e a classe social. Ao conceituar a brancura como conjunto de valores e significados sociais, problematizei a classificação racial de alguns sujeitos da pesquisa, cujo comportamento e condições de vida os aproximavam ou distanciavam da brancura. Sujeitos para os quais o corpo em certas situações não coincidiu como os significados mobilizados por eles.

No sexto capítulo estão concentradas as análises da memória escolar dos entrevistados, em que procuro destacar como a classificação racial, os significados de ser branco e a incoerência entre corpo e significados mobilizados por pessoas brancas ou negras se fazem presentes numa instituição que é espaço de interações raciais, buscando compreender como os discursos construídos na escola dão significado à brancura. 


\section{A brancura no corpo? Classificação racial dos sujeitos da pesquisa}

A intensidade da miscigenação da população brasileira resultou numa diversidade de fenótipos, classificados com base em critérios raciais e/ou descritivos, que embasaram a construção de um sistema de classificação racial múltiplo e que dá sustentação à ideia - há muito estabelecida nos estudos das relações raciais, tanto norte-americanos quanto brasileiros - da fluidez da classificação racial em nosso país (BILDEN, 1929; FRAZIER, 1942; HARRIS, 1971 e mais recentemente THELES, 2003 e SANSONE, 2004). A mestiçagem, todavia, não foi fator exclusivo na elaboração desse sistema, já que a composição racial de toda a América teve por base a mistura, em diferentes graus, de indígenas, brancos e negros, mas ensejou critérios de classificação racial que variaram de acordo com contextos nacionais específicos (WAGLEY, 1965).

Nos Estados Unidos, por exemplo, houve uma simplificação da classificação racial em que a figura do mestiço assumiu pouca relevância, sendo o binômio negro/branco suficiente para agrupar indivíduos provenientes de diferentes combinações raciais em apenas duas raças hierarquizadas e imiscíveis. O sistema classificatório norte-americano está ancorado na regra de hipodescendência, em que o filho de casal inter-racial é classificado de acordo com o status racial do progenitor considerado racialmente inferior (WAGLEY, 1965; NOGUEIRA, 2007 [1954]; FRY, 2005).

No Brasil, ao contrário, “dá-se grande importância às mínimas gradações de cor" (DZIDZIYENO, 1971, p. 8), havendo uma variedade de expressões para se referir à pertença racial da população nas classificações realizadas cotidianamente, além do uso de termos institucionalizados, principalmente os empregados nas Pesquisas Nacionais por Amostra de Domicílios (PNAD) e recenseamentos. (MAGGIE, 1996, p. 231). Essas diferenças mostram que a ideia da mestiçagem esteve sujeita à interpretação sociológica de fatos tomados a princípio como biológicos, mas que adquiriram feições variadas dependendo da composição racial da população e da política racial de cada país (MUNANGA, 1999).

Em nossa sociedade é comum a aplicação de qualificativos mais descritivos como claro, moreno, preto concomitantemente, ou em substituição, a termos que remetem à ideia de raça, como afrodescendente, negro e branco. A coexistência de dois sistemas de classificação, o binário e o múltiplo, agregam à ideia de mestiçagem fatores fisionômicos e socioculturais para determinar a condição racial dos sujeitos. De acordo com Fry, o sistema de classificação binário seria utilizado com maior freqüência por indivíduos provenientes 
dos setores médios intelectualizados, diretamente influenciados por sociólogos, antropólogos e pelos movimentos negros. Já o sistema múltiplo teria uso mais popular, permitindo às pessoas se classificarem de maneiras diferentes em cada situação ou contexto (FRY, 2005). Contudo, as duas maneiras de classificar racialmente indivíduos e grupos não são construídas de forma independente, pois mesmo os termos que fazem alusão ao fenótipo, característicos do sistema múltiplo, estão carregados de sentidos propriamente raciais, que muitas vezes remetem à origem ou ascendência, sendo que a cor funciona como metáfora da raça. Como afirma Guimarães:

Ainda que tal classificação [baseada no fenótipo] seja diferente de uma classificação racial, que na maioria das vezes carrega consigo uma doutrina racialista mais ou menos explícita, parece claro que as classificações não apenas sugerem a mesma doutrina, afinal usam a mesma nomenclatura, como dificilmente mantêm-se sem serem contaminadas com expressões abertamente raciais, tais como "mulato" ou "mestiço" (GUIMAR ÃES, 2008 p. 45).

Alguns estudos têm demonstrado as maneiras como brasileiros mobilizam tanto o sistema múltiplo quanto o binário em sua classificação racial. Brandão e Martins, investigando a classificação racial de 476 estudantes cariocas do terceiro ano do ensino médio, concluíram que $63 \%$ dos entrevistados utilizaram-se das cinco categorias de raça/cor do IBGE para se autoclassificarem em pergunta aberta, ou seja, utilizaram o sistema múltiplo. O restante, $37 \%$ da amostra, concentrou suas respostas nas categorias negro e moreno $(28 \%)$ ou utilizaram diferentes termos como mulato ou os descritivos loiro e claro (6\%). Outros 3\% não declararam sua cor (BRANDÃO e MARTINS, 2007).

Já Sansone, em pesquisa realizada com jovens baianos habitantes de bairros populares, concluiu que alguns termos, como preto, eram preferencialmente utilizados por indivíduos de gerações mais velhas e de jovens mais pobres, pessoas que "parecem aceitar certa imobilidade social”. Aqueles com renda melhor, que não desejavam se definir como pretos ou negros, usavam termos como "escuro", "pardo" e "moreno". Já o termo negro funcionava como "categoria sociopolítica de conotação positiva e constitui, por assim dizer, o termo politicamente correto", sendo usado por uma minoria dos entrevistados mais jovens para incluir tipos físicos diversos (SANSONE, 2004, p. 72-73).

Assim como essas pesquisas recentes apontaram, os participantes deste estudo lançaram mão dos sistemas binário e múltiplo para realizar sua classificação racial. Durante uma das aulas do curso que configurou campo desta pesquisa, num contexto marcado por um discurso centrado na figura do negro tanto como categoria política quanto 
como condição subjetiva, identitária, os participantes foram solicitados por mim a classificarem-se racialmente. As questões iniciais que nortearam a análise deste dado específico foram: Como os docentes entrevistados e os demais participantes que responderam aos questionários se classificaram em termos de cor e/ou raça? Que critérios utilizaram ao se autoclassificarem? E o mais importante para esta reflexão: Classificar-se como pertencente a um ou outro grupo racial produz ressonâncias nas respostas? Em outros termos, os significados de ser branco são construídos por negros e brancos de modos diferentes?

Como essa primeira classificação se deu num contexto muito mais amplo, durante a pesquisa de campo, começo descrevendo as tendências gerais de classificação racial realizada pelos respondentes aos questionários, para, em seguida, focalizar as respostadas dos entrevistados, procurando problematizá-las à luz dos dados presentes nos depoimentos.

Uma primeira característica a ser salientada foi a tendência do grupo de 37 professores a utilizar os termos da classificação de cor/raça definidos pelo IBGE - branco, preto, pardo, amarelo, indígena - em resposta às perguntas abertas: “Qual a sua cor?” e "Qual a sua raça?” como se pode verificar no quadro abaixo:

Quadro 3.1 - Autoclassificação de cor e raça de acordo com sexo dos participantes

\begin{tabular}{|c|c|c|c|c|c|c|c|c|}
\hline COR & PRE $^{r}$ & TOS & PAR & DOS & BRAI & $\overline{\operatorname{COS}}$ & MOF & ENO \\
\hline RAÇA & MULHER & HOMEM & MULHER & HOMEM & MULHER & HOMEM & MULHER & HOMENS \\
\hline NEGRO & 11 & 3 & 2 & & & & & \\
\hline BRANCO & & & 1 & & 4 & 1 & & \\
\hline INDÍGENA & & & & & & & 1 & \\
\hline HUMANO & & & & & 3 & 4 & & \\
\hline BRASILEIRO & & & & & 1 & & & \\
\hline $\begin{array}{l}\text { NÃO } \\
\text { DECLARADO }\end{array}$ & & & 1 & 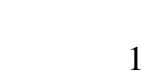 & 2 & 1 & & \\
\hline
\end{tabular}

Em 36 dos 37 questionários, o quesito cor foi aquele que apresentou o maior número de coincidências em relação às categorias oficiais de classificação racial, excetuando-se a categoria amarelo que não foi mencionada por nenhum dos respondentes. Trinta e seis docentes se declararam tendo tais categorias como referência: 16 brancos, 14 pretos, cinco pardos e uma indígena. A dispersão, característica do sistema de classificação racial brasileiro segundo alguns autores (MAGGIE, 2006), só se verificou no uso do termo morena por parte da mesma entrevistada que se classificou racialmente como indígena.

Como se pode observar, na tabela estão presentes apenas as respostas daqueles que declararam ao menos uma informação no questionário: cor ou raça, sendo que uma das 
professoras que preencheu o material recusou-se a responder a ambas as questões, além de deixar em branco a resposta à pergunta fechada alegando que nos documentos oficiais sou branca, mas como neta de índios, africanos e espanhóis de fato não saberia me classificar.

Outro ponto a destacar foi a recusa mais pronunciada à classificação racial em se tratando de pessoas que se autoatribuíram a cor branca e em menor proporção entre aquelas autoclassificadas como de cor parda. Isso faz supor que a classificação em bases mais descritivas, cromáticas, foi preferida por esses sujeitos, o que não implica a ausência da ideia de raça, como já destacado. Todavia, se os "brasileiros dão grande valor às mínimas gradações de cor" (DZIDZIYENO, op. cit.), essa tendência foi pouco expressiva, já que as cores parda, preta e branca agregaram o maior número de respostas, 35 no total. O que possivelmente reflete o contexto de politização e polarização racial em que tal classificação foi realizada.

Entre os brancos, três pessoas preencheram o item cor com a palavra branco e deixaram o item raça sem preenchimento, e outras sete usaram o termo raça humana para referir-se à sua pertença racial. Uma participante preferiu a expressão raça brasileira e outras cinco pessoas utilizaram a palavra branco para ambos os itens. Nesse grupo também se encontra uma estudante autoclassificada como de raça branca, mas que afirmou ser de cor parda. Ao ser entrevistado, Samuel, professor branco, ofereceu uma explicação bastante elucidativa para sua escolha da categoria humano a fim de demarcar sua pertença a um grupo:

Hoje eu falo, eu tenho esse conceito, eu estou tentando usar muito e até me educar sobre isso, etnia, eu não gosto de falar de raça, eu acho que raça é o seguinte, raça pra mim quando o pessoal fala nesse curso aí, tem que ser que nem o Érico Veríssimo quando ele foi aos Estados Unidos, perguntaram: "O que é raça pra você, de que raça você é no Brasil?" "Eu pertenço à raça humana", ele respondeu.

Com relação aos indivíduos que se declararam como pretos e pardos, apenas dois, autoclassificados como pardos, deixaram o item raça sem preenchimento. O restante usou o termo negro para completar o referido item. Assim, nenhum dos sujeitos pretos e pardos recorreu ao termo raça humana em sua classificação racial. Possivelmente porque já estejam tão acostumados a serem classificados de acordo com a cor e sejam alvos de tantos apelos, negativos e positivos, para integrarem um grupo racial, eles se identificam prontamente, sem recorrer a termos que negam a existência de raças como raça humana.

Este termo, por sua vez, pareceu caracterizar o apelo por parte dos respondentes brancos a uma origem comum de todas as pessoas, encerrando um sentido de 
universalidade, o que pode ser compreendido tendo por base as discussões efetivadas no curso a respeito da inexistência de raças humanas e a tentativa desses participantes de distanciarem-se do racismo e das teorias que propiciaram sua elaboração. Nas entrevistas, contudo, somente Márcio, autoclassificado como de raça branca, respondeu à pergunta "Quando falamos de diversidade racial você acredita que estamos falando de quais grupos?" com uma crítica direta ao conceito de raça:

Penso em negros, índios, ciganos, brancos. Penso na raça como construção social. Raça não é realidade genética, raça biológica é uma balela do século XIX que ajudou a Europa a dominar o mundo.

Os demais citaram os grupos negro, branco, índio e asiático, sem se referirem novamente à raça humana ou problematizarem o conceito de diversidade racial utilizado na formulação da pergunta, tal como fizeram, ainda que indiretamente, quando do preenchimento ao questionário.

Quanto ao quesito raça, o modelo bipolar negro-branco agregou o maior número de respostas, 22 no total: 16 negros e seis brancos. A dispersão ficou por conta do nãopreenchimento e da escolha da categoria humana.

Essa primeira classificação racial foi modificada por alguns docentes entrevistados: alguns que inicialmente haviam se caracterizado como brancos declararam-se negros ou afrodescendentes; os autodeclarados negros revelaram-se provenientes de famílias miscigenadas, e alguns mestiços narraram situações nas quais poderiam pertencer tanto ao grupo negro quanto ao branco. Falas que demonstraram como a autoatribuição de cor e raça variou até mesmo em contextos nos quais se manteve o mesmo interlocutor, tomandose por base a pesquisa de campo e a situação de entrevista. Essas oscilações parecem estar em conformidade com a afirmação de Sergei que embora se refira a contexto muito mais amplo, a análise de variações de classificação racial ao longo dos censos, ilustra a fluidez do sistema de classificação racial brasileiro:

Nem todos os filhos de mulheres brancas são brancos e nem todos os filhos de mulheres negras (pretas ou pardas) são negros (pretos ou pardos). Em outras palavras, a miscigenação e outros fatores que envolvem a identificação racial ao nascer também são relevantes. [...] Como no Brasil o critério de identificação racial é a autoidentificação, nada garante que as pessoas mantenham a mesma raça ao longo da vida (SOARES, 2008, p. 99).

Mais do que entender os fatores que condicionaram as mudanças de classificação racial dos sujeitos ao longo de sua trajetória de vida e nas entrevistas, interessa-me aqui investigar quais os critérios estabelecidos pelos entrevistados para a realização de sua 
classificação racial no momento da pesquisa e os possíveis conflitos que essa classificação ensejou.

Como se verá, o apelo à mistura biológica marcou o depoimento de vários professores. Embora as interações sociais fossem preponderantes para a classificação racial dos sujeitos no decorrer dos depoimentos, o casal parental inter-racial representou papel definidor na autoatribuição de cor/raça de mestiços, porém brancos, e mestiços, porém negros. Houve também aqueles que se referiram a uma ascendência europeia e mantiveram sua classificação como brancos ao longo de todo o processo de pesquisa. Da mesma forma, alguns docentes negros não mencionaram a presença de pessoas de outras pertenças raciais em seu círculo familiar e não modificaram sua classificação.

Na tabela abaixo segue a autoclassificação dos dez entrevistados obtidas através de questionário:

Quadro 3.2 Autoclassificação racial dos entrevistados

\begin{tabular}{|l|c|c|c|}
\hline & Cor & Raça & IBGE \\
\hline Márcio & Branca & Branca & Branca \\
\hline Samuel & Branca & Humana & Branca \\
\hline André & Branca & Humana & X \\
\hline Vitória & Branca & $X$ & Branca \\
\hline Carolina & Negra & Negra & Preta \\
\hline Sandra & Parda & Negra & Preta \\
\hline Roberto & Negra & Negra & Preta \\
\hline Cláudio & Negra & Preta & Preta \\
\hline Laura & Preta & Negra & Preta \\
\hline Sara & $\mathrm{X}$ & Negra & Parda \\
\hline
\end{tabular}

Mediante a tabela pode-se inferir que os docentes escolhidos para participar da etapa seguinte da pesquisa representavam inicialmente as diferentes tendências de classificação racial verificadas entre os demais participantes do curso, excetuando-se a professora que se identificou como descendente de indígena. Dos quatro brancos entrevistados, três não se classificaram racialmente e apenas Márcio, como se verá mais adiante, filho de casal inter-racial, optou por marcar seu pertencimento ao grupo racial branco. Dos negros, todos se classificaram racialmente, e Sara, também filha de casal inter- 
racial, não se classificou em termos de cor na pergunta aberta, mas declarou-se negra em resposta ao item raça.

Entre as variações mais comuns, a escolha de diferentes regras para estabelecer a pertença racial - como o uso simultâneo (ou alternado) dos critérios de marca e de origem - foi aquela que mais chamou atenção nos dez depoimentos. Começo com as análises dos depoimentos nos quais critérios de marca e origem foram coincidentes, sujeitos autoclassificados negros ou brancos cuja aparência e ascendência não problematizaram a classificação racial inicialmente escolhida em questionário, para em seguida focalizar aqueles que oscilaram sua classificação.

\subsection{Fluidas fronteiras - miscigenação, pureza e a classificação racial}

Foram entrevistadas pessoas para as quais corpo e ascendência coincidiram, o que possivelmente contribuiu para a manutenção da classificação racial inicialmente escolhida. Dentre elas, encontram-se Vitória e Samuel, autoclassificados brancos e Laura e Sandra, autoclassificadas negras.

Samuel e Vitória só utilizaram a categoria mestiço e/ou afrodescendente para fazerem referência a pessoas conhecidas e não a eles mesmos. Ambos relembraram a pertença racial de seus pais brancos e, além disso, ascendência europeia:

Na sua família são todos brancos, como é? - Todos brancos, todos brancos. Minha mãe é filha de libanês, eu sou neto de libanês. Os pais do meu pai são italianos, todos brancos. (Samuel)

Assim, o meu pai, a família do meu pai, meus pais são descendentes de espanhóis e portugueses (Vitória).

Talvez essa ascendência europeia tenha sido a responsável pela manutenção da classificação racial do/a docente ao longo das entrevistas. Nos depoimentos de ambos a regra de origem foi exclusivamente utilizada para caracterizar os sujeitos com os quais tiveram contato. Os filhos de casal inter-racial formado por negro e branco foram sempre categorizados por eles como negros:

Lá [no colégio particular em que trabalhava] eu tinha assim, o que é que eu tinha de alunos negros, eu tinha assim mãe haitiana casada com alemão, o filho era negro. (Vitória)

[...] E ele fazia um discurso, ele era negro, a mãe dele era loira e o pai negro, ele fazia um discurso racista. (Samuel)

A análise das entrevistas não deixa claro se as pessoas às quais ele e ela se referiram como sendo negras apresentavam características fenotípicas que condicionavam 
tal classificação, mas a referência à origem denota a aplicação da regra de hipodescendência, tomando os filhos por herdeiros da condição racial do pai ou mãe negro/a.

Num movimento análogo, duas entrevistadas autodeclaradas negras, Laura e Sandra, não fizeram menção à presença de pessoas de outros grupos raciais em seu núcleo familiar. Sandra atribuiu-se a cor parda em resposta aberta e na questão fechada, que apresentava as cinco categorias de raça/cor utilizadas nas pesquisas do IBGE, declarou-se preta. A questão da classificação racial foi pouco presente em seu depoimento e ensejou momentos constrangedores para ela durante nossa conversa:

Mas, eu fui educada assim, eu até pouco tempo atrás tinha vergonha de dizer, não que eu negasse minha negritude, mas, é melhor não falar sobre isso, porque é uma coisa meio pesada (Sandra, negra).

Tendo em vista as dificuldades em abordar a questão da classificação racial com Sandra, descritas no capítulo anterior, não foi possível entender qual o significado da diferença entre sua primeira classificação de cor e aquela escolhida ao final do questionário em pergunta fechada. Porém, a opção entre uma ou outra cor para se caracterizar não pareceu interferir em sua classificação racial como negra em todas as passagens da entrevista nas quais ela falou a respeito de sua pertença racial.

Laura, que também não mencionou a presença de pessoas de origem racial diversa em seu núcleo familiar, falou pouco sobre sua classificação racial, declarou-se negra e referiu-se a seus familiares constantemente como negrada, grupo sempre próximo cuja negritude era vivida e não falada. O viver a negritude foi relacionado pela entrevistada ao cultivo de hábitos considerados por ela como tipicamente negros: a freqüência ao candomblé e às rodas de samba de final de semana, além do contato com experiências de preconceito e discriminação racial, situações que não eram discutidas no contexto familiar.

As poucas referências à classificação racial e a manutenção da autoclassificação inicialmente escolhida por parte dos docentes Samuel e Vitória (brancos) e Laura e Sandra (negras) podem dever-se à homogeneidade racial de suas famílias. Situação diferente da relatada pelos demais entrevistados, que declararam que seus núcleos familiares eram compostos por pessoas racialmente diversas, condição que lhes permitiria reivindicar para si o status de mestiço, demonstrando como esta categoria encerra, além de um sentido propriamente racial, uma diversidade de fenótipos que permitem aos sujeitos atribuírem-se a cor preta, parda ou branca. 
Entre os docentes mestiços, termo que embora tenha sido utilizado apenas por Cláudio, Sara e Samuel, foi escolhido por mim para caracterizar seis entrevistados, encontravam-se os autodeclarados em questionário como brancos (André e Márcio) ou negros (Sara, Carolina, Roberto e Cláudio). A mestiçagem pareceu tornar as fronteiras raciais mais ambíguas no caso desses sujeitos. Como afirmou Márcio:

Essas fronteiras são... Pensei nos registros de nascimento das minhas tias, dependendo de quem levava pra registrar ficava de um jeito. Tinha duas tias claras na família, a tia Maria está registrada como branca porque minha avó - de ascendência italiana bem branca - que levou. Já minha mãe é parda nos registros porque meu avô - bem negro - é quem levou pra registrar. Outra tia ficou como negra no registro e a família toda ri disso.

No caso relatado acima, a classificação das filhas dependeu da aparência das crianças atrelada à pertença racial dos pais. Daí a disparidade entre a classificação das duas tias, descritas por Márcio como claras, e levadas ao cartório pela mãe bem branca ou pelo pai bem negro. Vê-se que ao mesmo tempo em que o avô e a avó do entrevistado foram heteroclassificados com base em marcadores físicos, uma vez que o responsável pelo registro desconhecia suas origens, a condição racial das crianças, mãe e tias de Márcio, remeteu à classificação atribuída aos pais [origem] somada à aparência das mesmas ${ }^{12}$. A mãe de Márcio foi registrada como parda em cartório, mas ele se referiu a ela como negra e afrodescendente, sendo que esta última expressão foi usada para classificar seus tios e tias, mesmo as registradas como brancas e descritas como claras.

Nos diferentes depoimentos, afrodescendente foi um dos termos escolhidos para determinar, assim como mestiço, uma diversidade de aparências, incluindo sujeitos que os docentes classificaram como brancos, negros, pretos, pardos e morenos, sendo usado por Márcio, Cláudio e Vitória com certa frequiência para caracterizar indivíduos nascidos de relacionamentos inter-raciais, independentemente de seu fenótipo, o que reflete uma classificação racial bipolar. Vitória apontou com precisão a abrangência do termo ao se referir ao marido:

[...] o dia em que eu falei que meu marido era afrodescendente ficou todo mundo esperando um negrão retinto [...] Eu podia ter tido um filho mulato com o J. e aí como ia ficar? Todo mundo olhando a cara dos dois: "Aquela mulher aprontou", eu falo, iam falar que eu aprontei tranquilamente [Pesquisadora: Por que fenotipicamente ele é branco?]

\footnotetext{
${ }^{12}$ Sara, professora autoclassificada como negra que na pergunta aberta recusou-se a atribuir-se uma cor, acrescentou à escolha da categoria parda na pergunta fechada, a informação: parda conforme o registro de nascimento, demonstrando que esse documento funciona como matriz de identificação, mesmo que não esteja em conformidade com a autoclassificação dos sujeitos.
} 
Exatamente. [...] Uma mistura fantástica. [refere-se à família do marido]... $O$ avô era mais escuro que você [que a pesquisadora], a avó branca, filha de alemães, a mãe mulata bem clara e o pai branco.

Vitória, que não teve filhos, acreditava que seria alvo de desconfianças caso a criança nascesse mulata, resultado da união entre ela, branca, e o marido socialmente reconhecido como branco, porém afrodescendente. Aprontar foi o eufemismo utilizado por ela para se referir à suposta infidelidade que um filho mulato sugeriria aos olhos de estranhos, uma vez que ela e o marido seriam "brancos para todos os efeitos sociais". (FREYRE, 2006 [1936], p. 744).

Márcio, por sua vez, utilizou para si mesmo a designação afrodescendente, embora tenha declarado pertencer à raça branca em diversas passagens de seu depoimento. Sua classificação fenotípica, branco eu sou de fato, não pareceu ser fonte de incoerências para sua definição racial cambiante: ora branco, em resposta ao questionário e em determinados trechos da entrevista, ora afrodescendente quando se referiu à sua posição como membro de família miscigenada.

Cláudio, que também se lembrou de parentes próximos que eram brancos, negros e descendentes de indígenas sugeriu que a possibilidade de um indivíduo proveniente de família mestiça classificar-se como branco seria estratégia de cooptação. Segundo ele,

[...] a cultura que criou essa possibilidade da miscigenação de dominar os negros, porque você põe uma gotinha branca no negro ele passa a ser branco também, "mas a minha cútis é negra", mas seu filho vai poder ser branco, mais clarinho, vai poder entrar aqui na casa grande.

Na estratégia de branqueamento apontada por Cláudio a alusão ao sangue remete à ideia de raça biológica e a mistura do sangue branco ao negro - sendo suficiente uma gotinha - possibilitaria aos mestiços acessarem não só a posição de brancos, ou mais clarinhos, como também o espaço social tradicionalmente reservado à brancura durante o período colonial: a casa-grande. O que demonstra a crença do entrevistado de que, a despeito de sua origem mestiça, indivíduos podem tornar-se brancos por meio de sua aparência e da ocupação de determinados espaços sociais.

Num movimento totalmente contrário à crença de Cláudio, André, autoclassificado como branco no questionário, filho de mãe bem branquelinha e pai que pode ser considerado negro, reivindicou para si o status racial do pai ao declarar: meu pai era negro e eu sou negro. Todavia, sua classificação baseada na hipodescendência e no seu fenótipo 
- branco de cabelo liso - resultara em momentos nos quais sua autoclassificação racial não correspondera ao modo como as pessoas com as quais teve contato o classificaram:

Pesquisadora: Você me contou situações em que você foi discriminado e quando você discriminava, você lembra?

André: Olha, eu lembro que eu reproduzia um pouco essa ideia, de quando alguém falhava, eu chamava "Oh o coquinho", acho que eu estava sendo massacrado e acabava reproduzindo o massacre era um pouco isso também. Eu sempre... Não querendo falar que eu sou... Mesmo porque eu estou na sua frente... Eu sempre respeitei todas as manifestações culturais, nunca passei por esse tipo de dificuldade, sempre gostei muito de me envolver com pessoas do movimento negro mesmo eu não sendo denominado como negro [mas você se considera negro?] Eu me considero, só que todo mundo [...] que você fala "Ah, mas você tem cabelo liso, branco do cabelo liso", mas meu pai era negro e eu sou negro.

A autoclassificação de André como negro, mesmo sendo considerado branco por colegas que contestavam sua classificação racial, pode dever-se a diferentes fatores que extrapolam os limites desta investigação. Porém, entre esses fatores deve ser considerado o contexto em que André fora selecionado: um curso em parte destinado a debater o racismo, a proximidade com pessoas do movimento negro durante as aulas, a própria situação de entrevista que propiciou a interação com uma pesquisadora negra e com questões relacionadas à condição de ser branco e ao seu posicionamento diante do racismo. Nesses contextos, afirmar-se negro era afirmar uma identidade não só racializada, mas politicamente comprometida com o combate ao racismo, uma identidade que contrariasse a ideologia do branqueamento, característica do "racismo à brasileira" (TELLES, 2003), descrita anteriormente por Cláudio.

Possivelmente, classificar-se como negro numa situação em que atitudes de brancos em relação a pessoas negras eram direta ou indiretamente problematizadas e criticadas proporcionaria o distanciamento do grupo ao qual se atribuía a discriminação racial, mesmo que essa atribuição não fosse verbalizada. Em outras palavras, ser branco num curso que questionava os privilégios construídos com base em hierarquias raciais poderia ser uma condição desconfortável. Talvez por isso a afirmação da negritude de André tenha surgido durante a entrevista em momentos muito específicos, quando questionado, por exemplo, a respeito de situações de preconceito racial presenciadas e de seu papel nessas situações, como exposto acima. Hipótese plausível tendo em vista outras passagens nas quais André se autodenominou branco e descreveu as implicações dessa classificação nas 
interações com outras pessoas ${ }^{13}$. O entrevistado disse que sua família era heteroclassificada e tratada como branca. Esse tratamento está presente, por exemplo, em episódio relatado por ele que, além de demonstrar seu reconhecimento social como branco na infância, envolveu intersecções entre discriminação racial e de gênero:

Como ocorreu com outra família lá [em que um rapaz branco engravidou uma moça branca], filha do seu Z. o sujeito foi obrigado a assumir. Quando o seu $G$. [família negra]... ocorreu a mesma coisa, ele não obrigava nem o sujeito, que nas outras famílias era normal que acontecesse isso, e a filha dele continuava em casa normal, só que diziam "Tá vendo? Só podia ser negro". Se ocorresse isso na minha casa, por exemplo, esse sujeito ele teria que assumir essa minha irmã, teria que casar com ela e viver com ela, ele teria que resolver a situação. [...] No caso das meninas brancas quando ocorria isso o sujeito tinha de assumir e casar, por isso que eu falo que era um lance de preconceito.

Questionado se naquele contexto era considerado branco, disse que: era, era considerado branco. Classificação que provavelmente garantiria o direito socialmente convencionado na cidade pequena em que morava, na Bahia, de cobrar reparação, através do matrimônio, de rapazes que, por ventura, engravidassem suas irmãs.

Outras situações de discriminação racial observadas por André na infância também demonstraram o distanciamento de sua família daquelas que eram reconhecidas como negras no contexto rural: só tinha uma família que de fato as pessoas consideravam negros, chamavam de negro. A expressão grifada parece indicar pessoas para as quais a negritude era incontestável, já que em trecho mais adiante o entrevistado ratifica a ideia: lá tinha a Semana Santa lá em casa, as pessoas passavam pedindo esmola, a maioria das pessoas que passava lá de fato era negra.

Outros entrevistados se valeram de tal expressão, ao que tudo indica, com o mesmo sentido presente no depoimento de André. Márcio, afrodescendente, utilizou a expressão branco eu sou de fato para fazer referência a seu fenótipo e a seu reconhecimento social como branco. De fato pareceu ser um termo empregado para marcar aqueles que independente da constituição racial da família eram socialmente reconhecidos como negros ou brancos, pessoas que na diversidade de aparências que caracteriza a população brasileira ocupariam os pólos mais claros ou escuros.

Sara, que se referiu à sua condição racial como dúbia e ambígua por conta de suas características físicas, disse que na infância ocupava uma posição confortável por não ser de fato considerada negra:

\footnotetext{
${ }^{13}$ Ver considerações a esse respeito também no item Interações em preto e branco, do capítulo dois.
} 
Agora não. Eu estou no meio dos negros de nível superior, mas quando eu estava com meus amigos negros na infância, eles até me valorizavam muito, tamanha era a depreciação que eles tinham de si próprios. Estar no meio termo acaba por te dar uma posição mais confortável do que quem não está. Eu acho que eu pude me encarar como negra, talvez porque naquele momento eu não era negra de fato, reconhecida socialmente como negra.

O conforto mencionado pode dever-se às diversas situações de preconceito racial observadas e relatadas, mas dificilmente dirigidas a ela; daí a possibilidade de se encarar como negra sem, no entanto, sofrer com os processos de autodepreciação identificados como peculiares aos colegas negros. Sara acrescentou que para ser considerado negro durante sua infância e juventude era preciso ser negro retinto mesmo, os outros eram morenos, ao contrário dos meios nos quais ela transita atualmente em que estão presentes negros de nível superior, contextos em que, possivelmente, a classificação racial se baseia em critérios que vão além do fenótipo.

Seria este o mesmo conforto expresso por André ao declarar: ser branco é confortável, porque ele está numa situação confortável, ninguém é preconceituoso com ele, ele fala o que quer, faz piadinha, tudo o mais e ninguém fala nada. Que fatores mobilizariam a identificação de André e Sara, pessoas que poderiam usufruir desse conforto identitário, a se classificarem como membros de um grupo alvo de preconceito racial? Nesses casos, ser negro é confortável? Em que contextos?

Divergências entre identificação racial e a categorização feita por terceiros foram apontadas também por Carolina, cujo irmão apresentava a mesma tendência em classificarse racialmente sem fazer menção a seu fenótipo, o que indica que outros contextos e situações presumivelmente diferentes daquele em que os docentes foram selecionados e entrevistados, também propiciam a classificação com base na hipodescendência. A família da entrevistada era composta por pessoas de ascendência branca, negra e indígena:

A minha mãe tem um aspecto assim de indígena, cabelo liso, boca, lábios e nariz finos, os traços bonitos de índio. O meu pai era negro, negro, com quem ela se casou, negro. Meu irmão - é irmão de sangue de pai e mãemeu irmão mais novo que eu, ela se separou quando estava grávida dele e meu irmão já nasceu mais clarinho, então ele não tem a pele negra, você olha você não fala que ele é um negro. [...] Eu tenho mais dois irmãos que são do segundo casamento da minha mãe, só que são totalmente diferentes, são brancos, minha irmã é muito clara, com cabelos lisos como os da minha avó, tem as características da minha avó e meu outro irmãozinho também, a gente o chama de caboclinho, ele tem o cabelo liso, mas ele se assume negro. 
A classificação com base na aparência marca o trecho do depoimento de Carolina, com exceção do termo caboclinho que tradicionalmente é usado para assinalar indivíduos provenientes da união entre índio e negro. Porém, é interessante perceber que embora ela tenha se referido a parte de sua família como branca, preferiu usar o termo clarinho para caracterizar o irmão que fenotipicamente não pôde ser classificado como negro - você olha você não fala que ele é negro -, porém, por ser ele fruto de casamento inter-racial - seu irmão de sangue de pai e mãe - a entrevistada optou por não defini-lo como membro do grupo branco como o que fez em relação aos demais familiares assim classificados: ela o classificou usando o termo descritivo claro.

Esse irmão, ao reivindicar sua negritude com base na pertença racial do pai e da irmã, se defrontou com questionamentos por parte de terceiros:

Ele fala que ele é negão, só que todo mundo fala "oh, porque você fala que você é negão?" "Porque eu sou, meu pai, meu avô, tenho irmã negra, eu sou negrão, eu não quero ser branco", tanto é que no Orkut dele tem lá "negro lindo" só que o pessoal olha e fala "cadê o negro lindo? Eu não estou vendo esse negro lindo", porque ele tem a pele clara e ele tem traços muito finos também, não tem traços negroides como eu tenho e... Não tem.

Chama a atenção, mesmo em se tratando de uma fala indireta, que a afirmação da negritude não apareceu sozinha, foi complementada pela frase eu não quero ser branco, frase que denota a negação da brancura, mas num sentido diferente de eu não sou branco, como seria de se esperar. Não querer ser branco talvez estivesse relacionado ao fato de que, apesar de reconhecido socialmente como branco, o irmão de Carolina recusava essa classificação, ou seja, ser ou não branco foi encarado por ele como uma escolha individual, que pôde ser recusada com base na origem racial de sua família. Esse caso citado foi o único mencionado pelos docentes que não se referia a suas próprias experiências, suscitando a indagação a respeito dos contextos freqüentados pelo irmão de Carolina que propiciariam a tendência de classificar-se como negro possuindo aparência categorizada como branca.

Esses excertos indicam a fluidez das fronteiras raciais e a limitação da classificação bipolar. Ao escolher entre as opções do binômio negro-branco e não optar pela classificação mestiço e suas variações, os sujeitos encontraram formas variadas para justificar sua pertença concomitante aos dois grupos. Uma dessas estratégias foi apontada por Márcio e Vitória, e se expressou na utilização do termo afrodescendente que para ambos pode indicar tanto pessoas brancas quanto negras. Ou seja, é possível a uma mesma 
pessoa classificar-se e ser socialmente tratada como branca sem que isso invalide sua ascendência; em outros termos, é possível ser um afrodescendente branco. Essa estratégia pode ser uma tentativa de operar com os critérios de classificação racial baseados tanto na marca quanto na origem e também ensejou momentos nos quais Márcio sentiu-se desconfortável quando sua origem mestiça foi revelada a colegas de trabalho: Quando eu estou falando com professores e eles descobrem que eu tenho negros na família dá um treco, eles começam a te olhar de uma outra maneira.

A ideia de mestiçagem foi fator preponderante para a utilização concomitante dos critérios de marca e de origem apresentados nos trechos ora analisados. Nessas passagens o fato de os entrevistados e seus familiares poderem ser descritos racialmente como mestiços tornou por vezes problemática a classificação baseada exclusivamente na aparência, principalmente em contextos nos quais sua origem mestiça era conhecida ou em que uma identidade racial em bases políticas foi assumida.

Por outro lado, quando a origem dos sujeitos era ignorada, mas insistiu-se numa classificação com base na ascendência, surgiu o conflito entre a auto e a heteroclassificação racial. No caso de mestiços claros, para utilizar um qualificativo comum nos depoimentos, sua autoclassificação como negros foi produtora de desconfianças para as pessoas com as quais conviveram, muito provavelmente porque, como afirma Telles, a mestiçagem não inviabiliza a classificação de muitos brasileiros como brancos:

[...] para muitos brasileiros que se identificam como brancos, admitir ter ascendência não-branca não é um problema. Embora a ideologia do branqueamento possa levá-los a subestimar esses ancestrais, alegar ter ascendência africana e ao mesmo tempo se identificar como branco não é uma incoerência no sistema brasileiro (TELLES, 2003, p. 118).

As dúvidas relatadas quanto à validade da classificação como negro ou negra de pessoas "brancas para todos os efeitos sociais" (FREYRE, 2006 [1936], p. 744) talvez se devam ao consenso de que, no Brasil, o fenótipo é mais acionado como designativo de raça e a origem é um dado que, quando conhecido, é usado de maneira secundária. Além disso, num país em que cores e raças são hierarquizadas, declarar-se negro, possuindo pele clara e traços finos, é visto por muitos como um contrassenso, dada a ideologia do branqueamento presente em nossas relações raciais.

No contexto estudado, a utilização do termo negro pareceu ter para esses sujeitos uma conotação política. A família mestiça foi acionada como marcador racial, em 
detrimento da aparência, principalmente por parte dos entrevistados claros. No caso de Sara, essa conotação foi mais explícita. A entrevistada descreveu sua família como intensamente misturada, configuração em que ela ocupava o pólo mais escuro: Eu sabia que eu era preta e a minha família sempre me tratava assim, pretinha [...] eu sou a negra da família, a caçula preta. Essa posição - a negra da família - foi construída tendo os parentes próximos como referência, a mãe de pele clara [...] traços de branco e o cabelo crespo casou-se com um homem negro de cabelos lisos, seu pai que ela só conheceu após adulta. Já os irmãos e irmãs da entrevistada eram frutos de outros relacionamentos da mãe e foram descritos como brancos, uma irmã é loira de olhos claros e a outra tem a pele branca e o cabelo preto. Sara não descreveu em detalhes dois irmãos já falecidos, disse apenas que eles eram brancos.

A menção à cor de Sara por parte de seus familiares foi interpretada por ela como expressão de afetividade na colocação de apelidos como pretinha e neguinha, segundo ela uma coisa carinhosa. Carinho que também se anunciava no uso de termos como galega e branquela para caracterizar suas irmãs. Ao tentar classificar-se como negra para além das manifestações de carinho, assumindo para si, em outros contextos, a designação racial que os apelidos familiares denotavam, Sara se lembrou de conflitos:

Eu dizia: "Também sou preta". Eu cresci a vida inteira ouvindo: "Você é morena, você não é preta, olha a sua cor, olha o seu cabelo. Olha só como são os seus amigos." Eu tinha amigos que eram quase que azul de tão preto. "Olha que diferença entre você e ele." [...] Essa coisa também sempre foi muito complicada. Na verdade, há bastante tempo, eu até já tive conflitos familiares, quando eu comecei me perceber negra, mesmo que antes me chamassem de neguinha.

A classificação contextual esteve presente no depoimento de Sara. Na família toda branca ela era considerada preta, menos por conta de uma classificação racial e mais em virtude da comparação entre sua cor e as de seus irmãos e irmãs brancos. Junto aos amigos e amigas negros era considerada morena e em alguns casos branca. A docente identificou o cabelo, que em comparação ao cabelo dos amigos negros era o melhor cabelo do mundo, e a cor da pele, como os principais marcadores que lhe permitiam transitar entre a classificação racial como branca ou negra: em alguns espaços eu era branca e em outros espaços eu era negra.

O fato de ser a negra da família e não conhecer o pai foi fonte de diversos conflitos para Sara, desde acreditar que era filha adotiva até os confrontos com a mãe para saber os motivos de sua diferença em relação às irmãs. Ela disse que sua classificação como negra 
era um ato de desafio frente ao silêncio da família acerca de suas origens paternas: Até essa coisa de desafiar, "eи sou preta", era pra saber como é que eu era. Esse desafiar acabou por tornar-se uma constante na vida de Sara, que revelou esforçar-se para marcar sua pertença racial, que não está tão evidente em seu corpo, através das roupas, do modo como penteia os cabelos, como se posiciona frente ao racismo:

Eu sou muito ambígua. Acho que a minha trajetória é muito ambígua. Eu me identifico, faço uma opção de que lado eu estou [...] porque eu me sinto mais confortável, não digo confortável, confortável não é, mas me sinto mais autêntica, me sinto melhor, mais fortalecida, porque também não tenho nada do outro lado.

O outro lado a que a docente se referiu diz respeito à posição daqueles que ela reconhecia como brancos, lado que poderia ter sido escolhido por ela, dada sua aparência. Segundo Sara, sua classificação racial foi realizada em bases menos fenotípicas e mais sociais:

Menos por conta da minha negritude, muito menos, eu acho que poderia ter ficado do lado dos brancos tranquilamente. Até porque essa história de... Eu sou mais exótica do que negra, sempre me viram assim. Eu sou uma mistura bonita. Uma cor bronzeada, o cabelo crespo, mas também não é tão problemático, uma bundinha grande, eu poderia ter ficado... Eu não fiquei por conta dessas outras características que eu tinha.

Essas características relacionavam-se à vivência de preconceito e à condição socioeconômica ocupada pela entrevistada na juventude, passagens que serão posteriormente analisadas. Mas vale ressaltar que essas outras características sociais foram apontadas por Sara como fatores que contribuíram para a sua identificação com o grupo racial também alvo de preconceitos, os negros. Fica a dúvida se no caso de André e Márcio, cuja classificação racial oscilou, está presente a mesma correlação entre opressões diversas e a pertença racial estigmatizada, já que ambos também relataram situações nas quais foram alvo de preconceito e discriminação, principalmente no contexto escolar. Dúvida que pode ser somente assinalada já que os docentes, ao contrário de Sara, não forneceram elementos em seus depoimentos para que sua classificação racial fosse interpretada para além da aplicação da regra de hipodescendência. Ressalte-se novamente que a classificação política, mesmo que possa ser apenas sugerida nos casos de André e Márcio, e não afirmada com apoio em evidências empíricas, como no caso de Sara, não foi referida apenas em bases sociais. Tais classificações acionaram a ideia de mestiçagem, talvez para validar, também em bases naturalizadas, a classificação racial desses docentes. 
A tendência a utilizar a mestiçagem como parâmetro de classificação racial não foi verificada nos depoimentos de Cláudio, Carolina e Roberto, que também se lembraram de parentes brancos e indígenas, mas se classificaram como negros. As menções à mestiçagem surgiram apenas nos momentos nos quais eles descreviam seus familiares. $\mathrm{O}$ excerto extraído do depoimento de Cláudio é ilustrativo dessa tendência: Naquele momento a minha relação racial é interessante, porque eu tinha parentes próximos que eram brancos, negros e descendentes de indígenas (Cláudio). Os depoimentos dos três indicaram que sua aparência não deixou dúvidas quanto à classificação racial, não gerou contradições entre a percepção de sua cor por terceiros e sua autoclassificação, já que não houve momentos nos quais eles relatassem conflitos nesse sentido. Para os três, a mestiçagem não foi suficiente para tornar as fronteiras tão fluidas como nos casos anteriormente descritos.

Para Cláudio, por exemplo, o fato de ser mestiço não lhe permitiu acessar a posição de branco. $\mathrm{O}$ que parece corroborar a ideia de Freyre de que a passagem de uma raça à outra só é possível para os que apresentam pele mais clara, sendo a "situação do mais escuro, quando em seu favor não intervenham motivos especialíssimos, quase igual a do negro [preto]" (2006 [1936], p. 788-89). Todavia, pessoas que não são percebidas e não se percebem como brancas devido a seus traços negroides, expressão usada por Carolina para descrever-se, em algumas ocasiões podem clarear-se, deixando, ainda que temporariamente, a condição de negras, sem, contudo, ingressarem de forma integral na condição de brancos. Assim, Roberto, que na Bahia vivia numa cidade de maioria negra, disse que certas vezes era possível ser quase branco:

Lá no interior da Bahia tem muitos brancos e aquela coisa, a consciência do mulato ainda não era maior como é hoje, então um mulato mais claro já era quase branco. O negro era bem mesmo [...] E às vezes eu ficava na dúvida se eu era realmente negro, se eu era moreno, se eu era pardo.

Vê-se que é possível abandonar a cor, deixar de ser preto ou negro, para ser quase branco. Dentre esses quase brancos estariam pardos e morenos cuja aparência não permitiria o acesso à brancura. As limitações para tornar-se branco e as divergências entre auto e heteroclassificação revelam que a preponderância de fatores sociais para a definição da raça/cor esbarra no corpo como dado objetivo, mesmo que a percepção desse corpo seja socialmente condicionada por significações puramente sociais. No limite, é o corpo culturalmente construído que embasa os questionamentos sobre a validade da classificação de hipodescendência por parte dos fenotipicamente brancos e da impossibilidade de 
pessoas com traços negroides se tornarem totalmente brancas, permanecendo na condição de quase brancas.

Ao relembrar hipótese de Ramos (1954) de que brasileiros mestiços que se classificam como brancos estariam a negar sua condição racial objetiva fica-me a impressão de que a complexidade da classificação racial de mestiços ou afrodescendentes discutida aqui encerra mais do que a simples negação do status racial de branco ou negro: envolve um processo de negociação que toma por base não só a condição racial - a mestiçagem - mas, também, as diferentes interações sociais estabelecidas entre brancos e negros e os significados construídos a respeito de ambos os grupos raciais. Nesta pesquisa, uma dessas situações de negociação foi condicionada pela própria relação entrevistadora/entrevistados e as oscilações e inconsistências na classificação racial puderam ser interpretadas como produtos de um contexto em que se discutiam abertamente relações raciais e o papel do branco nessas relações.

Em face das análises dos depoimentos relativos à classificação racial alguns pontos podem ser destacados:

a) A crença na ideia de raça que o apelo à mestiçagem e à regra de origem pressupõe.

b) A tendência a um movimento contrário ao branqueamento, um processo de enegrecimento, condicionado pela disposição em atribuir-se o status racial de negro, mesmo sendo categorizado de maneira diversa, tendência mais proeminente em André e Sara, mas relatada por outros entrevistados para fazerem referência a parentes.

c) $\mathrm{O}$ uso do termo afrodescendente, bastante utilizado nas discussões efetivadas no curso em que esses docentes foram selecionados, e que abrange os socialmente percebidos como brancos, negros, mulatos, mestiços etc. $\mathrm{O}$ termo parece exercer a mesma função de negro quando este é reivindicado por pessoas que declaram terem sido reconhecidas em certos contextos como brancas, numa situação geradora de conflitos.

Esses pontos obrigam a reelaboração do quadro inicialmente proposto para ilustrar a classificação racial dos entrevistados, adicionando novas questões trazidas pelos depoimentos, quais sejam: as oscilações de autoclassificação, as descrições feitas por eles mesmos que diziam respeito a sua aparência física e os modos como eles descreveram a categorização de si feita por parentes e outras pessoas com as quais tinham contato. 
Quadro 3.3 Classificação racial

\begin{tabular}{|c|c|c|c|c|c|c|}
\hline 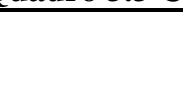 & Cor & Raça & IBGE & $\begin{array}{c}\text { Oscilações } \\
\text { na entrevista }\end{array}$ & Aparência & $\begin{array}{l}\text { Categori } \\
\text { zação }\end{array}$ \\
\hline Cláudio & Negra & Preta & preta & $\begin{array}{c}\text { Negro } \\
\text { mestiço }\end{array}$ & $\mathrm{X}$ & negro \\
\hline Carolina & Negra & Negra & preta & $\begin{array}{l}\text { Negra } \\
\text { mestiça }\end{array}$ & $\begin{array}{c}\text { Cabelo } \\
\text { crespo e } \\
\text { traços } \\
\text { negroides }\end{array}$ & negra \\
\hline Laura & Preta & Negra & preta & $\mathrm{X}$ & $\begin{array}{l}\text { Cabelo } \\
\text { crespo }\end{array}$ & negra \\
\hline Roberto & Negra & Negra & Preta & $\begin{array}{l}\text { Mulato } \\
\text { negro }\end{array}$ & $\mathrm{X}$ & negro \\
\hline Sandra & Parda & Negra & Preta & $\mathrm{X}$ & $\mathrm{X}$ & Negra \\
\hline Samuel & Branca & Humana & branca & $\mathrm{X}$ & $\mathrm{X}$ & Branco \\
\hline Márcio & branca & Branca & branca & $\begin{array}{c}\text { Branco } \\
\text { afrodescendente }\end{array}$ & $\mathrm{X}$ & Branco \\
\hline Vitória & Branca & $\mathrm{X}$ & branca & $\mathrm{X}$ & $\mathrm{X}$ & Branca \\
\hline André & Branca & Humana & $\mathrm{X}$ & $\begin{array}{l}\text { negro/moreno } \\
\text { /branco }\end{array}$ & $\begin{array}{c}\text { Pele } \\
\text { branca e } \\
\text { cabelo liso }\end{array}$ & Branco \\
\hline Sara & $\mathrm{X}$ & Negra & parda & $\begin{array}{c}\text { Morena } \\
\text { mestiça } \\
\text { branca/negra/ } \\
\text { preta }\end{array}$ & $\begin{array}{c}\text { bronzeada } \\
\text { cabelo } \\
\text { crespo }\end{array}$ & $\begin{array}{c}\text { branca } \\
\text { negra } \\
\text { morena }\end{array}$ \\
\hline
\end{tabular}


A última coluna traz informações sobre a categorização relembrada nos depoimentos e seria o equivalente ao reconhecimento social da raça dos participantes da pesquisa tendo em vista os marcadores físicos observados e avaliados por seus interlocutores. Dado importante já que "as distinções raciais feitas por outros, independentemente da autoidentificação, são fundamentais [...] nas interações sociais como também determinam as oportunidades na vida de cada um” (Telles, 2003, p. 304).

Mas o que significa ser socialmente reconhecido como branco? Qual o sentido de classificar-se dessa maneira? A classificação fenotípica é meramente resultado da percepção da pigmentação da pele? Se não é, que significados se atrelam à percepção da cor branca? Tentando responder às questões que vão além da classificação racial dos sujeitos, as reflexões seguintes procuram explicitar os significados de ser branco, tomando como base os depoimentos dos dez sujeitos da pesquisa.

As maneiras como os docentes foram reconhecidos racialmente e o modo como referiram a si mesmos nesses termos conformaram seu posicionamento diante da discriminação racial e de alguns dos significados construídos a respeito de ser branco. A posição assumida pelos falantes frente às situações narradas foi por vezes diferente, quando não antagônica em relação à autoclassificação racial, como ilustram os excertos abaixo:

Pra mim, eu ser branco ${ }^{14}$, pra mim não... Não me acho nem superior nem inferior, me considero uma pessoa... (André, ambíguo)

Eu não vou falar que eu não tenho vantagens, eu tive muitas vantagens, muitas de ser branca. (Vitória, branca)

Infelizmente, hoje o que é ser branco: é você ter as coisas na sua mão, é você ter tudo mais fácil. É difícil, eu não estou generalizando, não estou falando que não seja difícil, que pra todos é igual, mas é uma vantagem, oh! É uma boa e bela vantagem para eles. (Laura, negra)

Nesses trechos duas entrevistadas falavam sobre as vantagens de ser branco, mas partiram de perspectivas distintas. No caso de Vitória a vantagem não foi apenas mencionada, mas se relacionou às oportunidades reais experimentadas por ela ao longo de sua trajetória de vida em virtude de seu reconhecimento social como branca. Já Laura salientou a existência de diferenças nas condições de vida daqueles reconhecidos como brancos, mas também apontou a brancura com sinônimo de vantagem para terceiros -

\footnotetext{
${ }^{14}$ Note-se que nesse excerto o entrevistado denomina-se branco, ao contrário de outras passagens analisadas anteriormente.
} 
para eles - vantagem que ela não usufruía por ser negra. Já André, ao considerar-se uma pessoa, nem superior, nem inferior a outras, contrariou a avaliação de Vitória e Laura de que ser branco seria sinônimo de vantagem, atribuindo pouca relevância ao fato de ser muitas vezes reconhecido como integrante do grupo racial branco. A menção à inferioridade/superioridade demonstra que apesar de não encarar-se como superior em função da brancura, o docente estava atento para a existência de uma ideologia que hierarquiza racialmente os indivíduos.

Essas três falas ilustram a aproximação ou distanciamento dos entrevistados de acordo com a possibilidade que tiveram de se identificar e serem identificados como pertencentes a um ou outro grupo racial. Autoclassificados negros sempre responderam à pergunta "o que significa ser branco?" com respostas que denotavam seu distanciamento em relação aos sentidos mencionados. Aqueles que oscilaram significativamente sua classificação racial foram também ambíguos quanto aos significados de ser branco, descrevendo vantagens sociais asseguradas pela brancura, mas distanciando-se de tais vantagens em função de outras características que serão analisadas mais adiante. Já os que se afirmaram brancos durante todo o processo de pesquisa citaram os privilégios que usufruíram ao longo da vida e as maneiras como mobilizaram os significados de ser branco em suas trajetórias.

Para fins da análise que se segue os sujeitos foram agrupados em três diferentes classificações raciais: nos grupos branco ou negro foram considerados aqueles cuja hetero e auto-atribuição de cor/raça foram consistentes; no terceiro grupo foram considerados os que nem sempre foram percebidos como negros ou brancos, mas que se classificaram como negros em momentos pontuais. Nesse sentido têm-se:

- $\quad$ Negros - Cláudio, Laura, Sandra, Carolina, Roberto.

- Brancos - Vitória, Samuel e Márcio.

- Ambíguos - Sara e André.

Saliento que embora algumas pessoas que foram por mim qualificadas como pertencentes aos grupos negro ou branco tenham oscilado sua classificação racial, essas oscilações não se distanciaram muito da classificação inicialmente escolhida, centraram-se nas figuras de mestiços cuja aparência implicou na escolha entre as classificações branco ou negro. Destaco ainda que as classificações nesses três grupos foram realizadas somente para fins analíticos, sem a intenção de fixar as identidades raciais dos participantes. 
Além dos posicionamentos diferenciados assumidos pelos falantes dependendo de sua pertença racial, outro aspecto muito comum nas entrevistas foram as referências a sentidos generalizados sobre ser branco, caracterizando uma brancura abstrata cuja materialização no corpo dos sujeitos não foi necessariamente o foco das críticas e reflexões realizadas por professores negros e brancos, não havendo, desse modo, distinções nas falas de acordo com a autoclassificação racial ou com a categorização divisão apresentada acima. Até mesmo sujeitos brancos formularam conceituações a respeito da brancura que não coincidiram com os relatos de dificuldades e percalços que viveram e que estavam relacionados a outras posições sociais que ocupavam, tais como origem regional, classe social ou sexo. Nessas associações, a maioria delas relativas a uma brancura abstrata, o valor social de ser branco foi destacado, mostrando mais uma vez que a brancura não tem apenas uma dimensão corpórea, mas se relaciona a comportamentos e idealizações socialmente valorizados.

Essas passagens foram analisadas tendo em vista dois eixos: no primeiro deles, descrevo as características associadas à brancura que constituem um conjunto de valores e significados em sua maioria positivos; no segundo, analiso as falas que salientaram como esses valores e significados foram mobilizados pelos sujeitos segundo diferentes perspectivas, análise que começa no quarto capítulo, mas se estende para as reflexões realizadas nos dois capítulos subsequentes. 


\section{A brancura além do corpo - ser branco como um valor}

Para analisar as passagens citadas neste capítulo, tomei como embasamento o conceito de valor social proposto por Garner (2007). Segundo o autor, valores sociais têm estreita relação com a norma e representam um conjunto de práticas ou aspirações que adquirem sentido social e podem ser relacionados a grupos específicos ou encarados como um padrão a ser seguido por todos os membros de uma sociedade. Na sociedade capitalista, por exemplo, a acumulação de capital, a propriedade privada, a realização individual, são valores que podem ser contrastados àqueles concernentes ao bem-estar coletivo, partilha de riquezas, ausência de propriedade privada, dentre outros (GARNER, op. cit., p. 48).

Nas reflexões aqui realizadas procuro explicitar quais valores foram descritos pelos entrevistados como peculiares aos brancos, valores que projetavam os sentidos da brancura para além da cor da pele dos sujeitos. Para efetivar a análise, destaquei dos depoimentos associações entre brancura e valores que classifiquei como positivas, que davam sustentação à ideia de que ser branco era um privilégio que assegurava maior aceitação social ou vantagem, ambas relacionadas a avaliações estéticas e comportamentais.

Na construção da brancura como sinônimo de aceitação, os significados de ser negro, notadamente os depreciativos, foram sempre referidos pelos entrevistados em oposição às conceituações acerca da brancura, indicando que a atribuição de valores opostos de acordo com a pertença racial estava baseada em hierarquias raciais. As comparações foram realizadas pelos próprios participantes da pesquisa e fazem sentido apenas no contexto das relações descritas.

Embora parte dos valores relacionados à brancura não tenham sido citados diretamente, mas fizessem alusão ao processo de branqueamento que será tratado mais adiante, uma das falas coletadas mereceu destaque antecipado por causa das inúmeras características atribuídas à raça branca, mas deslocadas para descrever pessoas classificadas como negras. Trata-se de Samuel que, tentando explicar o que para ele caracterizava um negro de alma branca, frase usada para qualificar algumas famílias negras de sua vizinhança, disse:

Isso é o seguinte, se a pessoa - o que eu entendia na época, né? - se a pessoa era trabalhadora, era boazinha, era legal, honesta, tudo, então ela tem todas as características de um branco, só que ela é negra [...] "Aqueles negros são negros de alma branca". Então, quer dizer que eles tinham todas as características, todos os adjetivos, todas as qualidades do branco. (Samuel, branco) 
No excerto acima estão descritas todas as qualidades do branco segundo concepção partilhada pelos familiares de Samuel e que foram alvos de críticas por parte do docente. Vê-se que ao branco foram associados valores positivos como trabalho, bondade, honestidade, a princípio negados a pessoas negras que puderam cultivá-los em situações particulares.

O deslocamento da brancura e dos valores a ela associados para caracterizar pessoas negras sugere a "realidade autônoma" (COSTA, 1990, p.4) dos significados raciais ora discutidos. No exemplo acima, mesmo que comportamentos e características individuais contrariassem esses significados, estes permaneceram inalterados como características de negros ou brancos. Daí que para explicar o comportamento de pessoas negras trabalhadoras e honestas, cujo corpo não coincidia com os significados a ele atribuídos, fosse necessário considerá-las simbolicamente brancas.

As explicações do comportamento de pessoas e grupos baseadas, como esta, em dicotomias raciais, perpassaram boa parte das entrevistas. Nesses trechos a brancura configurou-se como sinônimo de diversos comportamentos ou características que os entrevistados não necessariamente reivindicaram para si, nem utilizaram para se referir a suas próprias experiências, mas que pareceram se relacionar a um "branco" que denominei genérico: positivamente retratado e muitas vezes descrito de maneira distante. Além de bondoso, trabalhador e honesto, esse branco genérico seria também belo, já que os docentes foram unânimes ao mencionar a existência de um padrão de beleza que valoriza a brancura, principalmente em se tratando de mulheres:

[...] a mulher negra, acho que ela leva muita desvantagem, perante a mulher branca em todas as oportunidades. Basta você ver o referencial de beleza na nossa sociedade. (Samuel, branco)

E boa aparência não é você ter o cabelo arrumado, você ter uma roupinha legal. Não é isso. A boa aparência é você ser branco. (Carolina, negra)

Para mulher branca é mais fácil. Eu sempre achei mais fácil ser mulher branca. Porque eu falo a mídia, a vida, o padrão europeu já a coloca como modelo, já a coloca como a bonita, e se ela ainda cai pro lado do ser loira acabou, ela já está aprovada de imediato. (Sandra, negra)

A correlação entre brancura e boa aparência citada por Carolina foi amplamente discutida pelos entrevistados nas reflexões sobre as oportunidades de trabalho diferenciadas de acordo com a pertença racial. A exigência de boa aparência, principalmente no caso das mulheres, foi avaliada como aspecto vantajoso para as 
mulheres brancas na escolha de candidatas a emprego, fato já investigado em pesquisas acadêmicas e considerado na elaboração de lei específica que coíbe a utilização do termo "boa aparência" em anúncios de emprego (DAMASCENO, 2000).

A menção de Sandra a um tipo específico de brancura - a loira - revela que quanto mais próxima a mulher estiver do referencial europeu, mais facilitada seria a inserção social e sua aprovação imediata, ao contrário de mulheres negras que ocupariam uma posição de desvantagem perante a mulher branca.

Indagado a respeito dos contextos de emergência de tal associação, Samuel atribuiu à colonização europeia a construção e imposição de um referencial de beleza que teria permanecido inalterado desde então. A manutenção desses modelos de estética branca foi atribuída pelos docentes à mídia e aos próprios brancos que, como beneficiários do padrão de beleza, o teriam incorporado sem grandes questionamentos:

O modelo de beleza é branco. Abre uma revista e é só isso. Diversidade não está na revista, na TV. (Márcio, branco)

Eu acho que o branco ele, ele tem uma ideia de naturalização da cor muito forte, a... É natural pra eles que o branco, eu acho né, que ele ache que o branco é mais bonito, que o branco seja mais inteligente, acho que pra eles é natural. (Roberto, negro)

No trecho do depoimento de Roberto não apenas encontra-se ratificada a associação entre brancura e beleza, como se verifica outra associação: brancura como indicativa de inteligência. $\mathrm{Na}$ avaliação do docente, tais associações seriam naturais para pessoas que se percebem brancas devido a um processo de naturalização da cor. Nesse sentido, a cor teria uma função bastante semelhante à ideia de raça, tal como proposta no século XVIII; sua percepção indicaria comportamentos e habilidades dos indivíduos que portam no corpo a brancura, sendo estas tomadas como naturais e não como fruto de construção sóciohistórica.

Laura, contradizendo em parte as conclusões de Roberto, argumentou que esses significados seriam construídos e incorporados à experiência branca não apenas de maneira irrefletida. Para a entrevistada, pessoas brancas teriam elaborado e cultivado deliberadamente os significados positivos atribuídos à sua raça em defesa de seus interesses. Ao responder à pergunta “o que significa ser branco?” ela destacou:

Então o que hoje é ser branco? É um emprego ser seu, é a sociedade, o respeito, você não tem que ficar sendo o melhor, não, o básico já está bom. E é muito ruim, essa sensação ainda é muito ruim, por mais que você esteja conversando, que você esteja ali, mas é muito ruim, não é 
uma sensação boa. E saber que as coisas não se constroem a partir disso, não deveria. Ou que muita coisa exatamente não é verdadeira, não é na sua essência exatamente por conta disso, porque os valores estão nesse tipo de coisa. E as pessoas introjetaram esses valores, todo mundo, por questão até de comodidade, de fortalecimento do clã, então introjetaram. "É isso mesmo e acabou". Então... Mesmo... Desde os revolucionários, os intelectuais, eu acho um absurdo isso vir a partir deles, alguns camuflados, outros descaradamente. E aí a gente está na mão de quem? (Laura, negra)

No trecho acima se destacam diferentes dimensões dos significados de ser branco: sua funcionalidade - os ganhos sociais e psicológicos para aqueles que os mantiveram e elaboraram; os motivos que levaram a sua elaboração - "fortalecimento do clã"; um grupo que teria introjetado tais significados composto por revolucionários e intelectuais; o olhar e avaliação de um "outro" racial sobre esses significados, neste caso, uma mulher negra. Para Laura, brancos formariam um clã com privilégios como o acesso facilitado ao emprego e ao respeito. Sua pertença racial asseguraria às pessoas brancas facilidade para se destacarem socialmente - você não tem que ser o melhor, o básico já está bom. Uma vez introjetados os valores associados à brancura, haveria pouco ou nenhum empenho para questioná-los, implicando o processo de naturalização descrito por Roberto.

A escolha da palavra clã para se referir aos brancos no coletivo é bastante curiosa, já que um clã se define como um conjunto de pessoas unidas por parentesco (não necessariamente biológico) e linhagem, possuindo um ancestral comum que pode ser apenas imaginado (FERREIRA, 1993). A ideia de clã evidencia a percepção dos brancos como integrantes de um grupo cujas ações ou omissões seriam compreendidas em função de sua lealdade a esse grupo, contrariando a crença de que ser branco é encarar-se e ser encarado como indivíduo comprometido apenas com seus interesses pessoais (PIZA, 2002a).

Contestando a avaliação de Laura, Vitória sugeriu que uma das vantagens de ser branca se relacionaria à possibilidade de ser tratada com individualidade: Sabe, ninguém nunca me chamou de branquela, eu tenho nome, eu tenho identidade. (Vitória, branca). No contexto do depoimento de Vitória ter nome e identidade significou não ser referida como membro de um grupo racial, ao contrário de pessoas negras com as quais a entrevistada convivia, especialmente seus alunos, denominados racialmente de maneira mais frequenteaquele negrinho -, conclusão que se coaduna à formulada por Piza de que o "lugar do negro é o seu grupo como um todo e do branco é o de sua individualidade. Um negro 
representa todos os negros. Um branco é uma unidade representativa apenas de si mesmo" (PIZA, 2002a, p.72).

Nesse mesmo sentido, Roberto, ao avaliar as diferenças de tratamento dispensado a mulheres negras e brancas destacou:

Tinha algumas pessoas que eram negras e a gente chamava "negra fulana", "negra Dora", por exemplo, que era prostituta. Se a prostituta era branca não tinha o adjetivo na frente, era sempre só o nome, mas se era negra aí tinha aquele adjetivo "nega fulana". (Roberto, negro).

No caso acima o adjetivo que denotava a pertença racial foi utilizado para marcar mulheres cuja conduta sexual era condenada na cidade em que Roberto crescera e reforçava estereótipos que associavam a negritude a tais condutas. Já mulheres brancas que se comportavam de maneira semelhante não representavam seu grupo racial, eram referidas pelo nome.

Vê-se que, em se tratando de brancos, a tensão entre indivíduo e grupo nem sempre gerou contradições, já que os autodeclarados brancos que mantiveram sua classificação racial ao longo da pesquisa, Vitória e Samuel, identificaram momentos em que foram privilegiados por sua pertença racial - beneficiados como integrantes do grupo branco - ao mesmo tempo em que a docente avaliou ter sido tratada com individualidade.

As diferentes avaliações expressas nas falas de Vitória e Laura podem decorrer da pertença racial de ambas. Vitória, sendo branca, pôde usufruir os benefícios de tal classificação, dentre eles o tratamento individualizado, já Laura, pertencente ao grupo racial negro e frequentemente referida nesses termos, encarou a si mesma como integrante de um grupo, identificando brancos da mesma maneira.

$\mathrm{O}$ apelo à individualidade de brancos - nunca me chamaram de branquela (Vitória), me considero uma pessoa (André) - foi mais visível nas descrições que não envolveram a ideia de privilégio racial, aqui entendido em bases institucionais e/ou estruturais. A ideia de que brancos compunham um grupo racial tornou-se explícita quando entraram em jogo as declarações acerca do privilégio de ser branco, expresso na conclusão de que ser considerado bonito, inteligente, trabalhador, bondoso e honesto em função da brancura resultou numa maior possibilidade de inserção social. A metáfora da sociedade como espaço de portas abertas para a recepção de pessoas brancas sintetiza essa percepção:

[...] lógico, como branca, eu tive todas as portas abertas, mesmo que fosse uma portinhola que eu tivesse que ficar de quatro, mas a porta estava aberta para mim. (Vitória, branca) 
Ela [uma pesquisadora] se especializou em História da África, ela é branca e todas as portas ela falou que se abriram pra ela, porque um branco quando vai pesquisar alguma coisa de negro é tudo muito mais fácil. (Carolina, negra)

[...] o branco tem as portas, todas as portas estão abertas pra ele, para o branco. (Samuel, branco)

[...] para as mulheres brancas a coisa flui um pouquinho melhor, você pode não ser tão intelectualizada, mas se você é bonita as portas se abrem. (Sandra, negra)

Nesses excertos as portas da pesquisa acadêmica, do mercado de trabalho e da sociedade em geral estiveram abertas para brancos. Apenas Sandra frisou uma segunda exigência: no caso de mulheres brancas, para que as coisas fluíssem ainda melhor, seria necessário ser bonita. $\mathrm{O}$ que demonstra que na opinião da entrevistada a correlação entre brancura e beleza nem sempre está disponível para mulheres brancas.

Para os entrevistados, a materialização dos sentidos de ser branco naqueles assim classificados funcionaria como chave que abre as portas da sociedade, ilustrando a correlação e retroalimentação entre privilégios simbólicos e estruturais em se tratando da raça branca, e indicando que, para aqueles reconhecidos socialmente como brancos, sua pertença racial e os significados construídos em torno dela não são vividos separadamente.

Além de dimensões não materiais e do privilégio na assunção de postos de trabalho, os docentes mencionaram que ser branco correspondia a ser proprietário, mesmo em contextos que eles classificavam como pobres:

Depois eu fui perceber que meus amigos mais pobres eram os meus amigos pretos e que eu morava numa casa e os proprietários eram meus amigos brancos (Sara, ambígua).

A Bahia tem uns apartheids, tem uns bairros mais ricos, são os bairros de gente da cor da pele branca, aí aqueles bairros cada vez mais pobres é mais negro, tem uns apartheids assim que são evidentes (Roberto, negro).

Eu achava que as famílias, hoje eu penso assim, na época eu não sacava isso, mas as famílias brancas talvez tivessem mais estrutura financeira do que as famílias negras. (Samuel, branco)

Assim, sujeitos brancos, individualizados e supostamente sem raça, destacaram a existência de uma estrutura que os beneficiaria, paradoxalmente, em virtude de sua identificação como membros de um grupo socialmente valorizado. Foi na assunção dos 
privilégios que a brancura deixou de ser mera aparência para configurar-se como condição racial favorável:

Pesquisadora: O que significava para você ser branco no contexto da infância?

Samuel (branco): A idealização já era branca, e como uma criança eu via uma questão de aceitação, de poder transitar por qualquer lugar, de poder chegar, de poder assim como se diz, enfim, ser aceito pela sociedade, era uma questão de aceitação, eu via isso aí.

Sobressai do excerto a palavra aceitação, tantas vezes reiterada e que não se limita à autopercepção como branco, mas ao efeito dessa percepção na relação com os outros. A palavra aceitação carrega em si sentidos de aprovação, acolhimento e crédito, resumidos no efeito de poder transitar em qualquer lugar. Efeito que se concretiza a partir de uma estrutura que o antecede e que foi nomeada pelo entrevistado como uma idealização branca.

Em decorrência da idealização branca e da aceitação incondicional, o branco figurou nos depoimentos como modelo de sucesso, (fala de Márcio) em diferentes âmbitos: na vizinhança, no ambiente de trabalho e, como será tratado no último capítulo, na escola. Esse modelo só foi problematizado em críticas a episódios de supremacia branca, quando da mobilização da ideia de raça em favor dos brancos de maneira mais explícita, especialmente por meio da discriminação racial. Se ser branco significou ser bom e legal, como anteriormente destacado, essas caracterizações positivas contradisseram, ao menos em parte, algumas imagens elaboradas a respeito dos brancos como discriminadores.

Desse modo, para esses docentes, a única associação negativa agregada à brancura foi a opressão. Fosse para incluírem a si mesmos como opressores, fosse para se distanciarem desse grupo, os entrevistados indicaram que a maioria das situações de preconceito e discriminação racial que haviam presenciado foram efetivadas por pessoas brancas que conheciam, quando não por eles mesmos. Porém, entre os autoclassificados brancos, essa associação - brancura como sinônimo de opressão - foi diretamente explicitada apenas por Márcio:

O homem branco tem a carga de ter sido opressor. Mesmo que você não queira, vem essa imagem. Foi o grande opressor, em termos de racismo, de sexismo. Não é uma imagem muito positiva, não dá muito orgulho. [...] Na verdade, nunca tive muita identidade com isso, minha família foi muito privilegiada, me possibilitou pensar diferente. (Márcio, branco) 
A família mestiça foi novamente lembrada como suporte para pensar diferente a condição de ser branco. Na concepção do entrevistado, essa condição não era uma imagem positiva, já que a brancura estava associada à elaboração do racismo e do sexismo; assim, sua materialidade em seu corpo não lhe era motivo de orgulho.

Note-se que o adjetivo branco foi utilizado para qualificar a palavra homem, sugerindo que, na elaboração de sua reflexão, Márcio não se referia aos brancos como um grupo homogêneo, mas dividido em função do sexo. As ações desse grupo específico não teriam apenas culminado no racismo, mas também seriam responsáveis pela construção do sexismo, indicando uma primeira hierarquia entre brancos baseada no sexo, além de uma origem comum para diferentes opressões, neste caso, opressões de gênero e raça.

Outros docentes autoclassificados brancos se referiram à opressão, porém de maneira indireta, por meio das diversas críticas a respeito da ideologia racista ou de condutas discriminatórias, mostrando a dificuldade que tinham em identificar-se como parte do grupo opressor, como mencionado por Márcio. Fato significativo, já que mesmo tendo participado de curso que abordava a desigualdade racial e entrevista em que algumas questões giravam em torno da referida temática, esses professores encararam a si mesmos como indivíduos não necessariamente comprometidos com uma estrutura excludente.

Já para os entrevistados negros, a brancura e a opressão foram correlacionadas de maneira explícita. Houve uma caracterização recorrente a respeito do poder do olhar do branco nos depoimentos coletados junto aos negros. Todos se referiram ao olhar de pessoas brancas com as quais tiveram contato, especialmente aquelas desconhecidas, como um olhar que ameaçava e constrangia em diferentes situações:

Quando eu vejo pessoas brancas me olhando [...] fico naquela coisa "Será que vão me maltratar? Será que vão me discriminar?" Mas, difícil acontecer isso, mas, assim, sempre tem alguma coisa, ele sempre vai falar alguma coisa, que vai deixar bem claro, demarcado, que ele é branco e que eu sou negra. (Carolina, negra)

Eu acho que o branco não tem ideia do que sejam os olhares. Eu acho que o olhar é uma coisa... Acho que o branco não tem ideia do que seja o poder do olhar, um olhar que te fere, um olhar de desconfiança por você ser negro, ele não tem ideia... (Roberto, negro)

Sinto essa violência, até mesmo na questão do olhar. (Laura, negra)

Eu me senti, digamos, em alguns momentos, incomodada. Pensando "que lugar é esse?", mas em momento algum houve destrato, mas houve olhares. (Sandra, negra) 
Nesses excertos a brancura foi relacionada não apenas à opressão, mas foi tomada como ameaçadora. O medo do outro - branco - foi sintetizado pelo poder de seu olhar. Um olhar nem sempre indicativo de preconceito, mas que, a partir de vivências anteriores de opressão racial, os docentes aprenderam a interpretar como uma discriminação em potencial, que pôde ou não se concretizar, mas cuja percepção foi fonte de angústia e desconfiança, chegando a ferir sua subjetividade. Carolina também destacou o esforço de brancos por manter as fronteiras raciais demarcadas por meio de falas ou ações, mesmo que tal demarcação não necessariamente chegasse a se transformar em discriminação.

Esse medo do que o branco possa fazer ou pensar faz supor que a brancura como bondade não foi sempre uma associação possível para todas as pessoas. Pelo contrário, no caso dos depoimentos acima, a brancura pode ser percebida como algo a ser temido. Como salientado por hooks (1999), pessoas brancas dificilmente estão atentas para essa dimensão de sua pertença racial:

Socializados para acreditar na fantasia de que a branquitude representa bondade, e tudo o que é benigno e não ameaçador, muitas pessoas brancas assumem ser essa a concepção de branquitude adotada também pelos negros. Elas não se dão conta de que a maneira como a branquitude se impõe à vida negra - freqüentemente, de forma aterrorizante de um poder que fere, machuca e tortura - é o que, em realidade, rompe a fantasia da branquitude como representativa da bondade. (hooks, $1997 \mathrm{p}$. 169 , tradução minha)

Essas associações negativas entre brancura e valores estão estritamente relacionadas àquelas avaliadas como positivas, já que a positividade de ser branco foi quase sempre referida nos depoimentos em contraposição à negatividade de ser negro, de onde a concepção de brancura como opressão. Desse modo, negritude e brancura são construções que, embora opostas, se reforçam mutuamente (DÁVILA, 2006, p.27). Sustenta essa relação um significado primeiro, aparentemente óbvio, mas cuja construção implica complexas hierarquizações de raça: ser branco é não ser negro. Isso não significa, contudo, que a condição de branco ou as conceituações a respeito da brancura não apresentem um núcleo próprio, mas que esse núcleo é basicamente excludente e depende com intensidade das construções a respeito daqueles que não o habitam. Essa exclusão primeira sugere que ser negro é ter acesso impedido aos significados de ser branco, exceto, como será discutido no próximo capítulo, quando negros tornam-se simbolicamente brancos, reforçando a ordem hierárquica dos significados de ser branco e evidenciando a ideologia racial que dá base a eles. 
A característica generalizada da brancura assumida por boa parte das construções que opõem negro versus branco sugere que mesmo que parte das associações positivas entre brancura e valores não fossem seguidas de exemplos concretos oriundos de experiências vividas pelos sujeitos da pesquisa, e que brancos não efetivassem a discriminação racial, apesar de terem seu olhar associado a tal possibilidade, tais características foram atribuídas aos brancos como grupo. Essas associações generalizadas podem ser compreendidas a partir da proposição de Costa (1990) de que

Para o sujeito negro oprimido, os indivíduos brancos, diversos, em suas efetivas realidades psíquicas, econômicas, sociais e culturais, ganham uma feição ímpar, uniforme e universal: a brancura. A brancura detém o olhar do negro antes que ele penetre a falha do branco. A brancura é abstraída, reificada, alçada à condição de realidade autônoma, independente de quem a porta enquanto atributo étnico ou, mais precisamente, racial. A brancura [...] funciona como um pré-dado, como uma essência que antecede a existência e manifestações históricas dos indivíduos reais, que são apenas seus arautos e atualizadores. O fetichismo em que se assenta a ideologia racial faz do predicado branco, da brancura, o "sujeito universal e essencial" e do sujeito branco um "predicado contingente e particular". (COSTA, p. 4)

Neste trabalho, não apenas sujeitos negros idealizaram a brancura, abstraindo condições de vida concreta de brancos, como os próprios brancos falaram a respeito de características que não são generalizáveis a todos os membros de seu grupo racial. No texto de Costa, assim como nesta reflexão, a brancura é entendida para além das dimensões do corpo e a pele branca funciona como "predicado contingente e particular" que, entre outros aspectos, permite que se pressuponham habilidades e condutas de pessoas que portam no corpo esse predicado.

As experiências dos sujeitos podem remeter aos significados de ser branco mencionados neste item, mas nem sempre estão em consonância com tais construções, como se verá nas considerações realizadas no capítulo subsequente. Por outro lado, a existência de uma idealização branca, ou de um branco genérico, possibilita uma identificação positiva para pessoas que se reconhecem e são reconhecidas como brancas, tal como indica o efeito de aceitação em virtude da pertença racial branca, mencionado por Samuel.

A aceitação e a vantagem foram os únicos significados presentes nos depoimentos de sujeitos brancos que remeteram às suas experiências de vida. Já para docentes negros, o contato com pessoas brancas em suas trajetórias também possibilitou que o branco genérico, positivamente retratado e potencialmente opressor, fosse contrastado a pessoas 
brancas reais, cujo comportamento nem sempre coincidiu com os significados idealizados de ser branco. Nesse sentido, Sara destacou que a convivência com uma de suas irmãs que ela classificou como branca ensejou associações negativas com a brancura:

Eu lembro que era eu que xingava a minha irmã de branquela azeda, de branca podre, eu xingava a minha irmã dessas coisas. Eu achava que minha irmã fazia o cocô mais fedido do que todo o mundo. A minha irmã era muito peidorrenta. A minha irmã é muito branca, muito branquinha e ela era muito cagona de pequena, peidava, então eu cresci associando a branquitude a isso. (Sara, ambígua)

Para além do possível ciúme entre irmãs, em especial pelo fato de uma ser percebida como branca e a outra não, a fala de Sara revela também efeitos da convivência cotidiana na conformação de significados não idealizados de brancura. Mas não apenas associações negativas como essa foram rememoradas da convivência mais próxima com pessoas brancas. Carolina, a mesma professora que elaborou uma série de relatos a respeito de brancos como ativamente discriminadores (falas que serão analisadas mais adiante), ao se lembrar do dia mais feliz de sua vida, quando concluiu seus estudos em nível superior, destacou a participação de pessoas brancas, anjos da guarda, que a teriam motivado a superar as barreiras interpostas à sua escolarização:

Tive a força de resistir pela minha profissão porque não queriam que eu estudasse, sempre vêm com aquelas barreiras. Mas sempre você encontra também anjos da guarda que te ajudam e falam: "Não, vai estudar, depois a gente se entende e tal" Eu tive um capitão ${ }^{15}$ que ele falava: "Não, você não tem que ir pra faculdade? Vai pra faculdade, deixa esse serviço aqui que depois você me paga com outro dia de sua folga, a gente faz um bem bolado, mas vai pra faculdade". Então eu tive essas pessoas que graças a Deus me ajudaram a estudar, a vencer. Tive pessoas brancas que me viram chorando, cansada, ali arrasada por um problema que passei, estar cansada e falar "Vou desistir disso tudo, voltar pra minha terra na beira do meu mar, tomar água de coco, deixar tudo isso" e a pessoa falar "Não, fica aqui, você já lutou tanto, não desista, vá dormir, vá relaxar" e te dar um copo de água e falar assim: "Descansa, relaxa, amanhã é outro dia, você é uma guerreira", então tem muito isso. (Carolina, negra)

Essas pessoas brancas mencionadas por Carolina não correspondem à imagem ameaçadora presente nos excertos a respeito do olhar do branco. As caracterizações desse olhar pareceram se referir a brancos desconhecidos, reforçando a generalidade de tal caracterização e sugerindo que os significados de ser branco apresentam dois patamares:

\footnotetext{
${ }^{15}$ Carolina havia trabalhado como policial militar antes de exercer a docência.
} 
um já citado, correspondente a construções generalizadas, e outro construído na interação e convivência que problematiza ou reforça o anterior.

Além das fronteiras entre brancos e negros, expressas nas falas analisadas, os depoimentos também estabeleceram diferenciações dentre os próprios brancos, que configuravam significados distintos em função da condição socioeconômica e do gênero, revelando que os significados de ser branco não se constroem somente com base na lógica de dicotomias raciais, mas se diversificam internamente, como será analisado a seguir.

\section{1 - Significados de ser branco e hierarquizações da brancura}

Os relatos que fizeram alusão às experiências de vida de pessoas brancas chamaram atenção para o fato de que sua pertença racial não foi experimentada de maneira isolada, mas se relacionou a outras posições de privilégio e subordinação ocupadas por brancos (FRANKENBERG, 1993). Esses outros lugares sociais para além da raça foram citados como fatores significativos na trajetória dos docentes, indicando a existência de processos de distinção interna na categoria "branco" que contribuíam para a diversificação dos significados de ser branco de acordo com outros elementos sociais, como o gênero e a condição socioeconômica. Muitas vezes, os entrevistados citaram essas intersecções explicitamente para descreverem o modo como enxergavam a sociedade brasileira. Samuel, por exemplo, ilustrando as diferenças entre as condições de vida de pessoas brancas e negras, destacou:

Você veja, eu imagino o Brasil como se ele fosse uma pirâmide social. Essa pirâmide você visualiza uma pirâmide [...] e lá no pico da pirâmide você vai ver, lá na ponta você tem que ser rico, branco e macho. Quer dizer, você tem que ser rico, branco e homem. Aí você vai descendo, mais abaixo [...] você pode ver a mulher branca, a mulher rica. Você vai descendo até você chegar à condição da mulher. Ela é mulher, negra e piora mais as coisas ainda como pobre. (Samuel, branco)

Nessa pirâmide, que remete à estratificação social no Brasil, encontram-se três eixos de privilégio/subordinação - condição econômica, raça e gênero - que se combinam numa figura cujas extremidades apresentam dois grupos opostos: homens, brancos e ricos versus mulheres, negras e pobres. Além desses eixos, o uso da expressão macho na construção da frase também pode se referir a outro componente de estratificação, relacionado à sexualidade: para ocupar o topo da pirâmide não basta ser homem, branco e rico, mas também macho, termo que no vocabulário popular é muitas vezes usado em substituição a homem heterossexual. 
Outras intersecções foram mencionadas de maneira menos evidente e, para analisálas, baseei-me na concepção de que

Um termo singular pode carregar significados de classe, status, raça, gênero e sexualidade; embora um ou mais desses significados geralmente domine, os demais podem estar, e geralmente estão, presentes, mesmo que de forma silenciosa ou transmutada (WRAY, 2006, p. 24, tradução minha).

Tomando por base a proposição de Wray, procurei analisar como a utilização do termo branco carregou em si significados oriundos de outros processos de diferenciação distintos da raça. Para tanto, na discussão a seguir serão destacados dos depoimentos os trechos relacionados à condição socioeconômica - diferenças de significado entre ser branco rico ou pobre - e ao gênero e sexualidade - diferenças de significado entre ser homem branco ou mulher branca. Começo pelas distinções dos significados de ser branco baseadas sexo.

\subsubsection{A castidade é branca e feminina - distinções de gênero nos significados de ser branco}

Nos depoimentos, um fator aglutinador das interações entre negros e brancos foram os relacionamentos afetivo-sexuais inter-raciais. Os relatos que remeteram a esses relacionamentos estavam carregados de estereótipos a respeito da sexualidade, principalmente feminina, e de significados raciais atrelados a ambos os sexos. Nessas passagens os sujeitos ou as pessoas por eles mencionadas ocuparam posições opostas em decorrência de seu sexo e sua raça. Negros foram retratados de maneira paradoxal: como objetos do desejo, porém colocados em segundo plano em se tratando de relacionamentos socialmente convencionados como sérios, como aponta a fala de Roberto:

Que é o paradoxo da formação do Brasil, negro pra diversão. No carnaval é maravilhoso, pra relação sexual, para os interesses sexuais o negro e a negra e tal. Mas, quando a coisa fica séria, aí é pejorativo. (Roberto, negro)

Os exemplos surgidos em resposta à questão "Existem diferenças entre ser homem/mulher negro/branco?" dados por outros professores corroboraram a proposição de Roberto. Neles, mulheres e homens negros foram caracterizados como possuidores de uma sexualidade exacerbada, caracterização já investigada por autores brasileiros que encontraram na figura da mulata e nas ideias correntes sobre a sexualidade negra os 
mesmos estereótipos presentes nos depoimentos aqui citados: os de uma sexualidade mais lasciva se comparada àquela apresentada por brancos (MOUTINHO, 2004; GIACOMINI, 2006).

Os entrevistados não necessariamente concordavam com tais imagens vinculadas à sexualidade negra, mas as citaram em observações acerca da sociedade brasileira, como indicado acima, ou para mencionar as ideias correntes em sua infância e juventude com as quais eles estavam familiarizados e das quais se valiam para entender/explicar as razões do desejo e de relações afetivas estabelecidas entre pessoas de grupos raciais diferentes. Essas ideias construídas em torno da sexualidade negra eram acompanhadas de outras, implícitas ou explícitas, sobre brancos. Em alguns depoimentos, às mulheres negras hipersexuadas correspondiam homens brancos cujo interesse por suas parceiras negras se dava apenas em termos pragmáticos:

Todo mundo acreditava que se um cara branco tava namorando uma mulher negra era porque ela era fácil. Tinha esse estereótipo da mulher negra fácil, mais fácil do que a branca que tinha sido criada com aquela moral cristã burguesa [...] Então a ideia da mulher negra era a prostituta. [...] Eu via a criança negra muito mais arrojada em relação à criança branca da época. Eles eram mais corajosos, eles eram assim mais, eu não teria palavras pra explicar pra você. Principalmente as meninas negras, em matéria até de costumes da época assim, sabe? Você chegava assim e você via que as meninas negras eram muito mais assim, da questão da sexualidade, dessas coisas, muito mais arrojadas do que as brancas da época, as brancas tinham aquela moral burguesa, aquela coisa mais casta. (Samuel, branco)

$\mathrm{Na}$ citação acima, a sexualidade feminina, negra ou branca, foi construída tendo como referência uma figura masculina e branca, ativa na escolha de parceiras de acordo com suas disposições individuais e capaz de identificar comportamentos sexuais femininos apenas em virtude da raça atribuída às mulheres. A explicação em que todo mundo acreditava para o namoro de brancos com negras foi remetida ao estereótipo já citado relativo às mulheres negras, mas, para além deste, outros significados racializados podem ser depreendidos do trecho do depoimento de Samuel: homens brancos envolvidos com parceiras negras seriam incapazes de basear seus relacionamentos na afetividade, buscariam nada mais do que a satisfação de desejos que não seriam plenamente atendidos por mulheres brancas. Estas, por sua vez, seriam sexualmente passivas, já que sua sexualidade estaria sujeita aos preceitos cristãos e burgueses relacionados à castidade, implicando numa regulação moral da sexualidade dessas mulheres que não seria gerida por elas mesmas, mas sim fruto de influências externas. Ao contrário de negras cujo 
comportamento supostamente seria mais permissivo em relação ao sexo, mulheres brancas fariam a opção por obedecer ao disciplinamento da moral cristã e da sociedade burguesa. Opção que, segundo o entrevistado, teria a ver com o modo como essas mulheres foram socializadas (criadas) e não necessariamente com sua pertença racial, evidenciando a crença de que famílias brancas burguesas ensinariam a castidade como um valor na educação das meninas.

Nesse sentido, pode-se avançar a hipótese de que a castidade seria um daqueles termos mencionados por Wray que carregam em si significados de classe social, raça, gênero e sexualidade, um termo construído no feminino, associado a valores avaliados por Samuel como burgueses, e que não apenas permitiria construir uma avaliação sobre a sexualidade de mulheres brancas, como supostamente as regularia.

Essa imagem da mulher branca como socializada para ser casta em conjunto àquelas relativas à masculinidade negra, hipoteticamente arrojada, encontra-se em episódio descrito por Samuel como sendo uma situação de racismo:

Eu me lembro de uma coisa da minha infância que me chocou muito também, tinha um rapaz negro e ele... E tinha uma senhora que era evangélica, ele começou a mexer com as filhas dessa senhora, eu me lembro que... $\boldsymbol{O}$ rapaz não era marginal não era nada. O quê que ela fez? Ela pegou, denunciou ele pra polícia, a polícia foi lá, algemou ele, colocou ele num poste e dando tapa na cara dele na frente de todo mundo. Foi um linchamento público sem você ter na época, como se diz assim, uma prova contundente pra fazer aquilo. Porque ele tava mexendo com a menina, agora eu nem saberia o nome da menina, nenhum momento ele ameaçou a integridade física da menina e tudo. Ele na época prometeu vingança, depois essa mulher que era evangélica foi embora de lá tudo, e elas eram brancas. Depois, passado certo tempo, você via outros rapazes brancos mexendo com menina e não acontecia nada.

A descrição do linchamento foi construída com imagens ambíguas e paradoxais de sexualidade, raça e violência: um rapaz negro encarado como agressor sexual em potencial, foi injustamente castigado; uma moça branca de família evangélica (exposta à moral cristã), descrita de forma passiva; a mãe, em contraste, foi quem tomou a iniciativa de chamar a polícia de modo a proteger a filha, mas não fez o mesmo em se tratando de pretendentes brancos; policiais, provavelmente homens, agiram violentamente em defesa da menina supostamente vítima de assédio.

A mescla de significados de raça, gênero e sexualidade revela a aproximação e o distanciamento de Samuel dos eventos narrados. Ao mesmo tempo em que ele classificou o episódio como sendo uma situação de racismo, procurou salientar que o rapaz negro não 
era marginal, e não havia ameaçado a integridade física da menina, num esforço por construir uma descrição positiva do sujeito agredido por policiais cuja ação foi criticada apenas porque não tinham provas contundentes para legitimá-la.

Vê-se que as divisões internas de brancura de acordo com o sexo - brancura como sinônimo de castidade feminina e virilidade masculina - não se opõem àquelas construídas entre os grupos raciais, fronteiras internas e externas se reforçam. Essas fronteiras foram destacadas pelos docentes em diversos momentos em que eles comparavam as avaliações contrastantes do comportamento de mulheres brancas e negras envolvidas com homens negros ou brancos. Numa dessas menções, a gravidez ensejou posturas opostas dependendo da pertença racial das parceiras:

Como ocorreu com outra família lá [em que um rapaz branco engravidou uma moça branca], filha do seu Z. o sujeito foi obrigado a assumir. Quando o seu $G$. [família negra]... ocorreu a mesma coisa, ele não obrigava nem o sujeito, que nas outras famílias era normal que acontecesse isso, e a filha dele continuava em casa normal só que diziam "Tá vendo? Só podia ser negro". [...] No caso das meninas brancas, se ocorresse isso [se engravidassem], o sujeito tinha que assumir e casar. Se acontecesse isso na minha casa, por exemplo, o sujeito teria que assumir essa minha irmã, teria que casar com ela, viver com ela, ele teria que resolver a situação. (André, ambíguo)

No contexto rural em que André viveu sua infância, rapazes que engravidassem moças brancas eram obrigados a assumir a situação por meio do casamento de modo a preservar a associação entre brancura e castidade feminina. Já em se tratando de meninas negras a gravidez reforçava as ideias preconceituosas que pesavam sobre elas e alimentavam a crença de que determinados comportamentos sexuais se deviam à sua pertença racial, crença expressa por meio do ditado popular só podia ser negro, referido por André. Assim, a castidade atribuída a mulheres brancas condicionaria o estabelecimento de relações de namoro ou o casamento, novamente em oposição àquelas instituídas ao casal inter-racial, como indica a avaliação de André a respeito do comportamento de seus amigos:

[...] agora estou falando do meu campo de amizades, só que quando, quando eu observo, consegui identificar claramente uma questão, dá pra observar. As meninas brancas são as preferidas quando se fala de namorinho; as meninas negras geralmente é um olhar diferenciado, olhar mais, me deixa ver bem a palavra, porque às vezes eu coloco palavras... [...] é aquela menina que o moleque olha e fala assim: "Essa é aquela que tem que zoar, vamos só pegar". (André, ambíguo) 
André salientou que a lógica de seleção e as atitudes diferenciadas em virtude da raça das parceiras não eram peculiares aos colegas brancos, mas eram ideias expressas também por seus amigos negros, revelando que nas hierarquias de gênero e raça, em se tratando de relacionamentos afetivo-sexuais, mulheres negras ocupavam posição desfavorável em relação a todos os demais indivíduos.

Essa posição de desvantagem não foi mencionada pelas mulheres negras entrevistadas. Embora duas delas tenham se lembrado de situações dolorosas suscitadas pelo relacionamento com homens brancos, as três entrevistadas negras eram casadas, ou seja, seus relacionamentos correspondiam àqueles convencionados como sérios. Todavia, mesmo os casamentos inter-raciais, supostamente mais sérios que namoros ou relações casuais, estavam sujeitos a interpretações baseadas em hierarquias raciais, como ilustrou Sara:

Minha tia fala assim: "Eu não entendi por que a sua avó casou com o seu avô, uma mulher bonita, estudada, casou com aquele seu avô, um grosso, caipira, da roça, tudo bem que ele era branco, ela era preta, mas era bonita, ficou parindo filho por esmo". (Sara, ambígua)

Nesse excerto a pertença racial, por meio de uma fala indireta, foi tomada de maneira diferente para mulher negra e homem branco. No caso da avó de Sara que era negra, mas era bonita e estudada, a conjunção indica que sua negritude era o fator que a depreciava. Em oposição, o avô que era grosso, caipira, da roça, tinha a brancura como ponto de compensação de tais características desvalorizadas - tudo bem que ele era branco. A concepção de que a brancura compensava as características sociais depreciadas indica que seu valor suplantava aqueles associados à instrução. Ser caipira e grosso não tornava a condição de ser branco secundária, pelo contrário, essa condição pareceu ser o ponto crucial para justificar a escolha de um caipira por parte de uma negra bonita $e$ estudada.

$\mathrm{Na}$ ideia de compensação acima exposta é possível apreender a existência de expectativas quanto aos critérios de seleção de parceiros não apenas com base na semelhança racial de ambos, mas em outros fatores de distinção social. Segundo Moutinho (2003), esses critérios evidenciam formas socialmente valorizadas de desejo que resultam em escolhas homogâmicas. Nestas, a expectativa é que pessoas escolham seus parceiros com base em critérios que não se resumem ao desejo ou afetividade. Provavelmente em virtude de tais expectativas, a tia de Sara pôde formular uma crítica à escolha da irmã. 
As avaliações negativas a respeito de casais inter-raciais sugerem a existência de formas de "desejar o indesejável", ou seja, formas de desejo e relacionamentos afetivos diferentes daquelas socialmente aceitas e valorizadas (MOUTINHO, op. cit. p. 51). Nos depoimentos, "desejar o indesejável" fez emergir explicações para o desejo que não se resumiram à afetividade e que estiveram relacionadas a assimetrias de gênero e raça, implicando em caracterizações diferenciadas a respeito dos significados de ser branco para homens e mulheres envolvidos em relacionamentos inter-raciais.

Tais significados, considerando-se as falas e silêncios a respeito de mulheres brancas, estavam associados à castidade, a uma sexualidade deserotizada, o que justificaria a escolha de parceiras negras por parte de homens brancos; à necessidade de proteção de terceiros contra investidas sexuais de homens negros; à maior sujeição aos discursos moralizantes, principalmente religiosos e burgueses; à possibilidade de circunscrever as relações afetivo-sexuais às convenções socialmente valorizadas, como namoro ou matrimônio.

Homens brancos, por sua vez, estavam associados à legitimidade de regular suas opções de acordo com padrões concernentes a sua masculinidade, escolhendo parceiras de um e outro grupo racial dependendo das expectativas atreladas aos relacionamentos. A satisfação de desejos sexuais justificaria seu envolvimento sexual com mulheres negras; já o estabelecimento de relações mais duradouras e com vistas à constituição de laços familiares condicionaria as relações de intimidade com mulheres brancas. Num e noutro caso, uma figura masculina e branca apresenta-se como ativa: homens brancos escolhem, não são escolhidos.

As poucas menções à sexualidade desse grupo também indicam que esta foi tomada como a norma, ponto sobre o qual os entrevistados tiveram pouco a considerar, em oposição às opiniões relativas à sexualidade feminina. A partir dessa norma, a sexualidade dos demais grupos foi definida como ameaçadora, mais ou menos lasciva, mais ou menos casta, propícia ou não ao reconhecimento social através do casamento.

O silêncio acerca da sexualidade de homens brancos também foi verificado por Moutinho (2004a), o que levou a autora a concluir que apenas através de comparações entre a sexualidade de homens negros e brancos - muitas vezes construídas com base em inferências suscitadas pela análise dos depoimentos coletados por ela - foi possível acessar concepções a respeito da sexualidade de homens brancos, fato que instigou a pesquisadora a questionar: 
Por oposição percebe-se que os atributos do homem branco são definidos pelo que o homem negro possui e aquele não possui. E creio que a palavra chave é "quentura". Mas, quais são os atributos do homem branco? Poderíamos especular, nesse sentido, que por oposição os homens brancos seriam "mais frios" ou "menos quentes" no ato sexual? [...] Caberia perguntar: onde está o branco procriador dos trópicos de Gilberto Freyre? (MOUTINHO, 2004a)

Ao que parece, nesta pesquisa, homens brancos se autorretrataram tendo como ponto de referência o branco construído por Gilberto Freyre ${ }^{16}$ e ausente nos depoimentos coletados por Moutinho (idem). Essa sexualidade supostamente "mais fria" que aquela verificada entre homens negros não foi citada por homens brancos entrevistados, possivelmente porque tais imagens não se ajustavam àquelas que eles construíram a respeito de sua própria masculinidade e virilidade e porque as declarações foram dirigidas a uma mulher negra, ou seja, o próprio contexto em que tais depoimentos foram proferidos pode ter corroborado a necessidade de construção de uma imagem de masculinidade viril.

Apenas uma das docentes por mim entrevistadas, Sara, relatou explicitamente a ausência de desejo ou interesse sexual por homens brancos:

[...] A minha irmã é muito branca, muito branquinha e ela era muito cagona de pequena, peidava, então eu cresci associando a branquitude a isso, eu vejo que é isso, por exemplo, até hoje eu não me sinto atraída por pessoas brancas, eu já tive um namorado moreno, pele clara e cabelo preto, foi há muito pouco tempo e eu nem tinha muita atração por ele. O que me chama a atenção, que me agrada os olhos, me agrada os sentidos não é o branco. Eu estou falando aqui, mas eu nunca falei pra ninguém, não falo isso pra minha família, pra minha irmã, pra minha mãe, mesmo em outros lugares eu não falo isso. É um sentimento de entranha, interno, que eu sinto dessa maneira. (Sara, ambígua)

A declaração de Sara, quase em tom confessional - nunca falei isso pra ninguém traz elementos acerca de suas preferências sexuais, de associações negativas com a branquitude e da própria relação de entrevista. Como anteriormente discutido, foi possível estabelecer uma atmosfera de cumplicidade entre pesquisadora e mulheres negras entrevistadas que propiciou relatos intimistas como o acima destacado. A docente explicou as razões de sua pouca atração por homens brancos lançando mão de associações negativas que estabeleceu entre a branquitude e o escatológico na convivência com a irmã muito

\footnotetext{
${ }^{16}$ A respeito da sexualidade de homens brancos no período colonial, Freyre destacou: "No senhor branco o corpo quase se tornou exclusivamente o membrum virile. Mãos de mulher, pés de menino, só o sexo arrogantemente viril" (FREYRE, 2006 [1933], p. 518). Esse senhor, descrito em Casa-Grande e Senzala como principal responsável pelo caráter mestiço do brasileiro, contrasta com aquele retratado em trabalhos mais recentes como possuidor de uma sexualidade menos potente; ver, por exemplo, os depoimentos analisados por Souza (2009) coletados junto a jovens homens negros.
} 
branca, não fazendo menção a componentes da sexualidade de homens brancos que pudessem, em conjunto com tais associações, condicionar a escolha de parceiros.

É preciso salientar que, com exceção da caracterização de homens brancos retratados como viris e com tendências sexuais diferenciadas das apresentadas por mulheres brancas deserotizadas, as imagens veiculadas nos depoimentos analisados parecem remeter a discussões brasileiras, já amplamente divulgadas, a respeito do comportamento sexual de homens e mulheres de um e outro grupo racial, ou do caráter pré-suposto de tais comportamentos. Ideias sobre a virilidade ameaçadora de homens negros (MOUTINHO, 2004b), a pré-disposição desse grupo à escolha de parceiras brancas (SILVA, 1991), a sub-representação de mulheres negras no "mercado matrimonial" (TELLES, 2003), a erotização exacerbada da mulher negra (SILVA, 2006) e a castidade como um valor para mulheres brancas (MOUTINHO, 2004c) foram destacadas por diferentes estudiosos(as) das relações raciais. A ausência de referências a uma sexualidade masculina, branca e viril nos trabalhos citados reforça a hipótese de que os relatos que fizeram alusão a esse ponto em particular estavam relacionados, entre outros aspectos, à própria situação de entrevista.

Outro ponto a destacar foi a comparação presente em boa parte das passagens ora analisadas entre a sexualidade de brancos e negros e as diferenças de tratamento dispensado às mulheres de um e outro grupo racial, indicando, mais uma vez, que os significados de ser branco nos relacionamentos afetivo-sexuais foram construídos num duplo movimento de diferenciação: um interno, que marcou significados distintos para mulheres e homens brancos, e outro externo marcado pela distinção entre os significados de ser branco e ser negro.

Assim como o sexo, as condições socioeconômicas também exerceram influência fundamental na caracterização da brancura. Se os relacionamentos inter-raciais foram considerados sob a ótica da discriminação racial, evidenciando o racismo imbricado nas avaliações do casal inter-racial, a condição socioeconômica foi construída em alguns depoimentos como fator que promoveria a amenização do racismo ou formas menos danosas de expressão dessa ideologia.

\subsubsection{Ser branco e pobre é ser racista cordial - distinções nos significados de ser branco em função das condições socioeconômicas}


Se fosse possível distribuir os participantes desta pesquisa na pirâmide imaginada por Samuel que interseccionava posições de raça, condições socioeconômicas e sexo, apenas dois deles corresponderiam a um dos extremos indicados por ele: Laura e Sandra, mulheres negras que relataram situações em que se reconheciam como muito pobres e estariam alocadas na base da pirâmide. Os demais estariam dispersos ao longo da figura representando diferentes combinações do trio de privilégios/opressões classe, raça e gênero, citado por Samuel. Além da diversidade de lugares sociais de raça e sexo, esses docentes possuíam condições socioeconômicas também diversas. Embora oito deles tenham se classificado como pobres ${ }^{17}$, as análises dos depoimentos revelaram nuances e distinções marcantes entre as situações narradas por diferentes sujeitos, indicando que na categoria pobre havia diferenças que condicionavam subdivisões.

Laura e Sandra - negras - e Márcio - branco - se classificavam como muito pobres, especialmente no contexto da infância. Sara e André - ambíguos - e Carolina negra - mencionaram oscilações em suas condições financeiras principalmente em função da migração da região Nordeste para o Sudeste. Samuel e Vitória - brancos - se referiram a infâncias pobres, porém confortáveis, com pais assalariados e mães donas de casa. Cláudio e Roberto reconheciam-se como pobres na infância, mas, quando comparavam suas situações àquelas vividas por vizinhos, classificavam-se como pertencentes à classe média ${ }^{18}$.

Os depoimentos foram diretamente influenciados pela condição socioeconômica dos sujeitos. Sua autopercepção como pobres produziu ressonâncias nas maneiras como eles descreveram as condições de vida de pessoas brancas. Nessas passagens brancura e privilégio nem sempre estiveram associados.

Tal como salientado por Teles (2003) e Sansone (2002), uma primeira influência relacionada à condição socioeconômica desfavorecida referiu-se à possibilidade de sociabilidade inter-racial tendo em vista a proximidade com indivíduos pertencentes a grupos diferentes daqueles escolhidos na autoclassificação dos sujeitos. Nas pesquisas conduzidas por esses autores, a proximidade socioeconômica entre negros e brancos foi encarada como fator que tornaria as relações raciais menos assimétricas, mais harmônicas. Bairros pobres foram caracterizados como "áreas moles" por Sansone (op. cit.) e apresentariam "relações raciais horizontais", de acordo com Telles (op. cit.), em

\footnotetext{
${ }^{17}$ Ver perfil dos docentes no Capítulo II.

${ }^{18}$ Ver considerações sobre as implicações de classificação racial, significados de ser branco e condições socioeconômicas também no capítulo V.
} 
contraposição a contextos mais elitizados, considerados por Sansone como "áreas duras" em que se estabeleceriam "relações raciais verticais" (TELLES), contextos marcados por um racismo mais explicito e institucionalizado.

Porém, nesta pesquisa, a proximidade das condições socioeconômicas de negros e brancos propiciou a elaboração de imagens dúbias a respeito de brancos: ao mesmo tempo em que estes criavam relações de amizade e intimidade com pessoas negras, valiam-se da ideia de raça e dos privilégios associados à brancura e os expressavam, principalmente, nos momentos de disputa e/ou conflitos, como ilustra o excerto abaixo:

Samuel: Sempre tive, eu tive amigos negros, amiguinhos da escola negros, jogava bola com eles, convivia uma vida normal com eles. Só que nós, quando eu era garoto, sempre a gente colocava aquela questão, já existia esse racismo.

Pesquisadora: E como era?

Samuel: Na medida em que está perdendo numa, como eu poderia dizer pra você, quando você está numa briga, numa disputa, aquela coisa de criança que você começa a apelar. Eu me lembro que tinha um amigo meu que chamava $C$., [...] e eu me lembro que ele era um negro, aquele negro bem afro, era não, é ainda, e ele ficava brincando, ele ficava zoando com a gente e os amigos começavam a fazer piadinha de negro, a tentar menosprezar ele, sabe aquela coisa apelativa quando você tá perdendo numa, numa, numa...

Pesquisadora: Numa disputa?

Samuel: Numa disputa, no papo, aí o pessoal jogava aquilo, e aquilo era sempre usado como um artifício, como uma apelação, como uma coisa assim pra menosprezar o colega que tava do lado lá. Ele era geralmente, quando não faziam piadinhas com ele, quando não faziam piadas, qualquer coisa qualquer discussão, "Ah! Só podia ser negro, só podia ser preto! Só podia ser isso. Preto quando...” Sabe né? (Samuel, branco)

Outra repercussão da condição socioeconômica dos docentes nos depoimentos foi a construção de uma distinção com base na classe social por meio do uso da expressão branco pobre, termo utilizado para diferenciar os brancos beneficiados pelas hierarquias socioeconômicas daqueles que, mesmo brancos, ocupavam lugares sociais muito próximos de indivíduos negros e de outros grupos subordinados. Samuel, novamente, foi aquele que melhor sintetizou tal diferenciação:

Quando eu falo branco pobre é por uma questão de classe, de classe social, eu já vou sair com você, já vou sair destacando dessa temática de etnia. Quando eu falo branco pobre, eu falo assim, a luta do negro não é uma luta só do negro, é uma luta do negro, do branco pobre, do nordestino, dos homossexuais, de todas aquelas pessoas que são exploradas, espoliadas e massacradas pelo neoliberalismo [...] Existe o branco pobre, aquele trabalhador, aquele cara que levanta às 5 da manhã e vai trabalhar, é neto de italiano e vai trabalhar. Ele está junto com o negro, estão os dois na mesma luta. Então, quando eu pego esse termo assim, eu falo muito mais da tomada de consc... Pra distinguir, pra 
discernir uma diferença entre o branco. Porque se para o negro, se você fala isso na sala de aula ${ }^{19}$ pra criança, pra criança todo branco vai ser inimigo, e não é. [...] A questão da discriminação, ela existe em qualquer seguimento, mas quando você fala branco pobre é uma questão de classe social. Que aí entra o conceito de classe, de você distinguir isso aí e falar: "Olha, o inimigo seu não é todo o loirinho de olhos azuis, é aquele cara que pertence à classe dominante, que é filho de liberal etc." (Samuel, branco)

A classe social foi tomada como um divisor da categoria branco, não apenas em relação ao diferencial de poder entre brancos pobres e ricos, mas como fator que aproximaria brancos pobres de outros grupos explorados e espoliados, dentre eles negros, nordestinos e homossexuais. Ao destacar da temática de etnia, palavra preferida por Samuel para aludir às diferenças que trato por raça, o entrevistado pôde agrupar diferentes tipos de opressão criando uma categoria mais abrangente representada pela designação de pobres e, mesmo apontando divisões internas nesse grupo - homossexuais, nordestinos, negros -, ao aglutiná-lo em torno das condições socioeconômicas foi possível fazer a distinção entre os inimigos - brancos da classe dominante - e pobres (amigos?).

Ser branco pobre, nessa interpretação, seria estar sujeito à mesma opressão sofrida por outros pobres. Apesar da heterogeneidade do grupo, a opressão teria resultados semelhantes: acordar cedo, pegar ônibus junto com negros trabalhadores e assim como eles, lutar por melhores condições de vida.

A pobreza como aspecto relevante de diferenciação entre brancos foi mencionada também por entrevistados negros. Sandra (negra), por exemplo, lembrando-se da composição racial do bairro periférico onde morava, destacou: Os negros eu acredito que sim, historicamente foram empurrados [para a periferia], junto com toda a massa de pobres brancos também.

Nesse mesmo sentido Vitória (branca) se lembrou que Paraisópolis está lotado de branco paupérrimo e de negro paupérrimo, isso não quer dizer que é por causa da cor da pele. Ela, assim como Samuel, encarou a heterogeneidade racial de áreas pobres como comprovação de que a questão racial seria pouco relevante para pensar a pobreza, já que há negros e brancos vivendo em situação semelhante. Ambos concluíram que seria possível pensar as desigualdades sociais destacando da temática da etnia e ignorando a cor da pele,

\footnotetext{
${ }^{19} \mathrm{O}$ excerto traz também a dimensão do trabalho pedagógico com a temática racial e demonstra a apreensão de Samuel de que o debate sobre racismo possa ensejar animosidades entre alunos negros e brancos. Dessa apreensão surge a necessidade de distinguir quem é o inimigo; do contrário, na interpretação do professor, corre-se o risco de que a criança negra identifique todo loirinho de olhos azuis como tal.
} 
ou seja, minimizando os efeitos da desigualdade racial na determinação de lugares socioeconômicos favoráveis para brancos, já que existe um grande número de brancos pobres.

Esse movimento foi contrário em se tratando da influência da condição socioeconômica na condição racial dos sujeitos. Se a raça, na interpretação desses entrevistados, teve pouca ou nenhuma influência nas divisões de classe, o oposto - a condição socioeconômica influenciando a raça e as interações raciais -, foi citado por negros e brancos. Nessas passagens a situação socioeconômica atuou de maneira diferenciada para os grupos raciais aqui tratados. Brancos pobres não apenas seriam mais próximos de negros, como estariam menos sujeitos à influência da ideologia racista, ao contrário de brancos ricos, que foram caracterizados como mais ativamente discriminadores. Já negros economicamente favorecidos se distanciariam dos significados depreciativos relacionados à sua pertença racial, situação dificultada para negros pobres.

Se a condição de ser branco foi associada à opressão racial nas caracterizações generalizadas a respeito da brancura, ser branco pobre problematizava tal associação, embora não a diluísse por completo. Samuel, por exemplo, reconhecendo a possibilidade de a ideologia racista estar presente nas camadas populares, fez nova distinção a respeito das maneiras como ela se apresentava de formas diferentes dependendo do contexto e da condição socioeconômica:

Ele [o branco pobre] discrimina, ele discrimina sim, mas eu acho que não com tanta intensidade como o rico, ele, talvez, ele é um racista cordial. Você fala assim: "O branco pobre é um racista cordial". Ele convive com a família negra, ele pode até não aceitar o negro como parte dele, mas eu acho que a questão do racismo é muito menos intensificada do que lá em cima, então é muito mais fácil você entrar numa loja de um branco na periferia e fazer uma compra, do que você ir lá ao shopping Morumbi ou na Faria Lima e ficar andando lá. Então eu acho que ele aceita mais. A questão da discriminação, ela existe em qualquer segmento, mas quando você fala branco pobre é uma questão de classe social. (Samuel, branco)

Note-se que a fala de Samuel foi construía em terceira pessoa, o que sugere a generalidade de sua reflexão. O termo racista cordial foi explicado pelo entrevistado tendo 
como referência a pesquisa realizada pelo Datafolha em $1995^{20}$, citada em trecho anterior de sua entrevista de modo a ilustrar seu ponto de vista. Fundamentando sua reflexão nessa pesquisa, Samuel concluiu que a discriminação racial mudava de intensidade em função da condição socioeconômica. Para ele, ricos seriam mais racistas que pobres. A ênfase na intensidade do racismo reflete a crença de que a diferença entre a supremacia branca verificada entre pessoas pertencentes a classes sociais diversas seria tanto quantitativa quanto qualitativa, ou seja, as manifestações racistas seriam fruto de uma maior ou menor adesão dos indivíduos pobres e ricos a essa ideologia, ao mesmo tempo em que o racismo entre pobres foi qualificado como cordial.

A cordialidade, todavia, não foi tratada por Samuel como evidência de ausência da ideologia racista nas camadas populares, mas foi considerada como uma forma peculiar de expressão de tal ideologia tendo em vista as condições socioeconômicas de brancos pobres ou ricos. Assim, na concepção do docente, o resultado da combinação de pobreza e brancura seria a harmonização das relações raciais, mas não a ausência de conflitos dessa ordem, indicando consonância entre a concepção de Samuel e as proposições de Sansone (op. cit.) e Telles (op. cit.) destacadas acima.

Porém, a lógica da argumentação de que ser branco pobre equivaleria a ser racista cordial esteve ausente de boa parte dos depoimentos de docentes negros, o que pode indicar que independentemente das condições socioeconômicas do agente que praticou a discriminação racial, ela foi experimentada como marcante por esses sujeitos.

Apenas Sandra lembrou que a frequência a um restaurante que ela classificou como destinado à classe média paulistana foi responsável pela primeira situação em que ela se sentiu discriminada por conta de sua pertença racial:

Então esses problemas que a gente trabalha aqui [no curso] que a gente realmente tenta levar e evitar na sala de aula eu não me recordo desses momentos. [...] Na adolescência eu me lembro que o primeiro namorado que eu tive na adolescência nós fomos ao Terraço Itália [...] Lá eu percebi que só tínhamos eu e ele de negro, aí sim, olhares... O garçom demorou muito para vir servir a gente [...] ai percebi que tinha alguma coisa errada, porque tinha muitos olhares para mim e para meu namorado e demorou muito. Até que ele se enfezou e chamou a atenção

\footnotetext{
20 A pesquisa publicada sob o título "Racismo Cordial" foi realizada pelo Datafolha e seus principais resultados podem ser sintetizados em dois dados: $89 \%$ dos mais de 5.000 entrevistados acreditavam na existência do racismo na sociedade brasileira, mas apenas $10 \%$ admitiam ser preconceituosos, o que reforçou a conclusão de Florestan Fernandes de que o brasileiro tem preconceito de ter preconceito, tendência interpretada pelos realizadores da pesquisa como um indicativo de cordialidade: "A imensa maioria dos brasileiros demonstrou ter ou estar inclinada a ter atitudes preconceituosas em relação às pessoas negras, mas quis minimizá-las. Uma demonstração de cordialidade, para não ofender ainda mais aquele que se discrimina" (FOLHA, 1995, p. 12).
} 
do garçom, sem baixar o nível, aí rapidinho... Nesse momento eu percebi alguma coisa estranha, hoje todos os lugares que frequento eu observo. (Sandra, negra)

Sandra morava numa comunidade pobre em que os quatro cantos que você olhava caíam negros, concentração que foi lembrada como fator que minimizava os efeitos do preconceito racial, sugerindo que, para ela, a identificação racial semelhante da maioria de seus vizinhos, e não suas condições socioeconômicas, condicionava relações raciais mais harmônicas. Porém, seu bairro pode ser considerado uma zona de conforto racial em meio a outros espaços sociais. Essa interpretação foi ratificada por ela em outras passagens de seu depoimento, em que relatou outras vivências de preconceito quando de seu casamento inter-racial e de sua migração para a região Sul do país, ocasião em que foi morar numa cidade de maioria branca e concluiu que aquele povo tinha problemas em aceitar o negro, do mesmo modo como no restaurante frequentado majoritariamente por brancos.

Os demais entrevistados negros não se referiram a seus bairros como zonas de conforto, pelo contrário, as relações entre vizinhos foram lembradas como responsáveis por boa parte dos conflitos raciais. Mesmo os dois professores negros que se declararam pertencentes à classe média - Cláudio e Roberto - citaram momentos que alternavam a amenização das relações raciais em função de suas condições econômicas e experiências com a discriminação racial, como será discutido adiante. A discriminação foi possibilitada não apenas pela pertença ao grupo branco, mas, na construção de distinções da condição socioeconômica de brancos, a raça ocupou papel de destaque, resultando que brancos pobres se distinguiam não apenas de brancos ricos, mas também tinham condições de vida melhores que negros pobres.

As fronteiras condicionadas pela posição socioeconômica ensejaram construções divergentes a respeito da brancura para negros e brancos. Se as primeiras associações discutidas neste capítulo indicavam uma convergência entre as opiniões dos dez sujeitos da pesquisa a respeito de uma idealização branca, as indicações de que ser branco pobre significava ser também oprimido e ser racista cordial foram problematizadas pelos entrevistados negros tendo em vista as experiências com a discriminação racial nos bairros pobres onde a maioria deles cresceu. Nos depoimentos encontravam-se sugeridas reelaborações e influências mútuas de fronteiras econômicas e raciais, mesmo em contextos que os entrevistados avaliaram como pobres, sugerindo que a dicotomia pobre/rico não foi suficiente para explicar as hierarquizações verificadas entre negros e 
brancos pobres. Dito de outro modo, ser branco em contextos de pobreza foi indicativo de ter melhores condições de vida que vizinhos negros, o que não invalida as ideias anteriormente descritas sobre fronteiras internas na condição de brancos em função da condição socioeconômica, mas indica a influência da raça na definição do status de brancos moradores de bairros pobres racialmente heterogêneos.

Essas reelaborações das noções de pertencimento de classe e pertencimento racial indicam que a "construção social da raça envolveria a transformação social de alguma dimensão de ascendência biológica, tipicamente vinculada a uma marca física, em uma hierarquia de status social” (SANTOS, 2005, p. 25). Nesta pesquisa, a marca física pele branca foi considerada pelos entrevistados como símbolo de status não apenas racial como signo socioeconômico privilegiado. Nas reflexões que se seguem, procuro analisar como o status social esteve relacionado à brancura, com base em depoimentos que evidenciaram a percepção de que pessoas que gozavam melhores condições socioeconômicas eram categorizadas pelos sujeitos entrevistados como brancas.

\section{Reelaborando fronteiras de classe e raça - discriminação racial e os significados de ser branco}

Neste item exploro de maneira mais direta como os significados de ser branco embasam ações de discriminação racial de indivíduos cuja brancura é influenciada pela pobreza, argumentando que mesmo em se tratando de brancos pobres os significados construídos em torno de sua pertença racial lhes asseguram a mobilização da ideia de raça em seu favor.

Todos os entrevistados se lembraram de episódios de discriminação e preconceito racial em suas trajetórias. Nessas ocasiões, docentes negros e brancos ocuparam duas posições nos relatos: espectadores ou participantes. Esta última subdividia-se entre aqueles que discriminavam e aqueles que eram alvos da discriminação. A condição de espectador foi mais comum em se tratando de pessoas brancas. Já a posição de alvo da discriminação racial foi exclusivamente lembrada por sujeitos negros. A oposição binária negro discriminado/branco discriminador esteve presente nas falas diretamente relacionadas à discriminação racial. A inversão dessa lógica expressa em frases do senso comum tais como "negro também é racista" não se verificou em nenhum depoimento, o que demonstra que, em relação às desigualdades raciais, os entrevistados tinham ideias bem definidas a 
respeito das hierarquias e das diferenças de poder entre negros e brancos e que ser branco foi também relacionado à prática da discriminação.

A possibilidade de praticar a discriminação racial em diferentes contextos, mesmo que essa prática não fosse lembrada em detalhes, foi mencionada por Vitória (branca) ao ser indagada a respeito de suas atitudes frente a situações de discriminação:

Eu não me lembro assim de ter sido... Eu devo ter sido, não sou nenhuma santa, mas eu não me lembro, não estou me lembrando mesmo, não estou lembrando. (Vitória, branca)

Já Samuel, ao contrário, foi o único entrevistado branco a se lembrar extensamente de diversas ocasiões nas quais reproduzia ideias preconceituosas a respeito de negros e atribuiu a aprendizagem de tais ideias à sociedade e à família:

Eu não sei nem se você viria a perguntar no caso agora, a questão de etnia naquela época, de raça, de negro, era uma coisa muito preconceituosa. Eu fui criado... Eu percebia pelo discurso, pelo próprio discurso da minha mãe... Hoje em dia talvez não, né? Pelos discursos dos meus tios, dos parentes, da própria rua em si, da sociedade, das crianças que viviam com a gente.

Como é possível constatar, mesmo antes de a questão acerca de vivência de preconceito racial ser colocada em pauta, Samuel antecipou-se falando abertamente dos discursos aos quais havia sido exposto na infância e adolescência, discursos que ele absorvia sem entender e que vêm sendo questionados por ele desde seu acesso ao ensino superior.

Os docentes evidenciaram que os episódios descritos são atualmente interpretados como casos de discriminação e preconceito racial, mas na época em que os vivenciaram eram situações tomadas como naturais. André, descrevendo as diferenças de tratamento dispensado a negros e brancos ilustrou essa tendência: Mas tendo uma visão de hoje eu posso falar que é preconceito, era... Todo mundo aceitava aquilo, é como o professor outro dia na outra aula dizia, naturalizou.

Nesses episódios, como já afirmado, a posição de agente da discriminação racial foi ocupado exclusivamente por pessoas brancas e os entrevistados negros, principalmente, ofereceram uma diversidade de relatos a respeito disso:

[...] eu cresci percebendo que branco era igual a mim. Quem colocou essa coisa que diz que eu sou diferente do branco foram os próprios brancos, eu acho, no meu ponto de vista, que começa a te relegar para os cantos, para os fundos, para as cozinhas, te inferiorizar, eles que me fizeram, talvez ser... Viver na defensiva. Eu não vou dizer pra você que eu não tenho meus preconceitos, eu tenho, sou uma pessoa preconceituosa também, mas assim, pra falar que eu já agi de forma 
preconceituosa com um branco, não. Porque eu fico mais na defensiva, sabia? (Carolina, negra)

Vê-se que mesmo reconhecendo ter certos preconceitos, Carolina salientou que nenhum deles se reverteu em situação de discriminação em relação a pessoas brancas. Ela também destacou um dos efeitos da experiência com o racismo: viver na defensiva, postura que, no contexto de seu depoimento, denota sua constante apreensão diante do convívio com pessoas brancas, apreensão baseada na associação entre a brancura e a opressão, analisada anteriormente. A posição do branco na construção da inferioridade negra foi apontada pela docente, para quem a construção da diferença racial e de lugares predeterminados para negros - os cantos e cozinhas - foram produtos das ações de pessoas brancas. A elaboração dessa imagem teve a ver com conflitos raciais experimentados pela entrevistada. Uma das ações de brancos descritas remeteu diretamente à construção da cozinha como lugar reservado para negros:

Quando ele [tio branco] deu uma festa uma vez, uma mulher ficava me pedindo muito as coisas e eu servia, porque era a minha casa, eu sabia onde estavam as coisas. Só que uma dessas vezes em que essa mulher pediu alguma coisa, acho que eu demorei pra atender, não fiz, esqueci, e ela veio falar comigo rispidamente como se eu fosse uma empregada, $e$ meu tio viu aquilo, brigou com a mulher, falou: "Está pensando o quê, que ela é empregada? É minha sobrinha, nem se ela fosse empregada era pra tratar assim". No fim, a festa acabou e aquilo me chocou um pouco [...] (Carolina, negra)

$\mathrm{Na}$ família de maioria branca, Carolina e o avô eram os únicos reconhecidos como negros, fato suficiente para que ela fosse percebida como empregada da casa e tratada de maneira ríspida por uma das convidadas da festa. Sua categorização como negra resultou na elaboração de fronteiras de condições socioeconômicas e status entre ela e os demais convidados. A categorização racial fazia com que Carolina não apenas fosse estranha à família como aos demais convidados, nessa interpretação só restava uma explicação para a sua presença na festa: ela estava ali para servir.

Esse relato emergiu quando a entrevistada se lembrava que durante a infância e a adolescência as pessoas que compunham seu círculo de convivência eram brancas:

Tinha a divisão, tanto é que tinha bairros com pessoal negro, com o pessoal pobre. Eu tive a sorte de ter um avô e uma avó que trabalhavam muito, a gente não morava no centro da cidade, mas morávamos num bairro legal [...] meu convívio era com pessoas bem mais claras do que eu, sempre teve isso. (Carolina, negra) 
Destaque-se que a explicação para a ascensão social da família mestiça remeteu à ideia de que trabalhar muito condicionaria a ocupação de espaços sociais privilegiados, neste caso, o acesso a bairros habitados por pessoas de condições sociais melhores cujos moradores seriam mais claros. A categoria pobre, a que Carolina declarou pertencer, coincidia com a raça, indicando que numa mesma comunidade classificada como pobre havia distinções socioeconômicas que se entrecruzavam com a pertença racial, resultando em bairros vizinhos ocupados de maneira quase exclusiva por pessoas brancas ou negras, dependendo do seu poder aquisitivo.

Outros docentes se lembraram de que a paisagem de seus bairros era homogênea em termos raciais, sendo possível encontrar divisões semelhantes às relatadas por Carolina:

Pesquisadora: Como era a convivência com pessoas diferentes [...]?

André: Quando eu cheguei aqui em São Paulo em 88 [...] eu morava na Duque de Caxias, que era avenida principal, então a maioria das pessoas lá, poderia dizer assim, eram as pessoas que tinham uma condição melhor e tinha um bairro abaixo que chamava Rua dos Barreiros onde morava a periferia, vamos dizer assim, o lado mais periférico, mais pobre. E lá tava concentrado os mais negros, aí sim tinha uma questão muita séria mesmo, porque nós lá de cima, nós ficávamos com medo, nosso pai falava: "Você não vai pra Rua dos Barreiros porque lá só tem maconheiro, não vai". Mas meu pai nunca falou "Não vai lá porque tem negro", entendeu? Ele falava só "não vai lá porque tem maconheiro", só isso. (André, ambíguo)

A concentração de negros supostamente drogados numa das ruas próximas à casa de André era fonte de preocupações para seu pai, preocupações que em outro trecho da entrevista o docente classificou como infundadas, com base na constatação de que muitos meninos brancos moradores da Rua Duque de Caxias faziam uso de drogas, enquanto muitos meninos negros que viviam na rua estigmatizada não o faziam. André frisou que a justificativa apresentada por seu pai para impedir sua circulação na Rua dos Barreiros referia-se ao medo do consumo de drogas e não à pertença racial dos moradores, porém, ao se lembrar das limitações ao convívio com pessoas diferentes, como indicava a pergunta dirigida a ele na entrevista, as primeiras características rememoradas foram a condição socioeconômica e a raça daqueles que moravam em áreas cujo acesso era proibido para ele e seus irmãos.

Sara e Samuel ofereceram outros exemplos de distinções raciais dentro da categoria pobre, além de ilustrarem a coincidência de tais distinções na ocupação de áreas num mesmo bairro: 
Depois eu fui perceber que meus amigos mais pobres eram os meus amigos pretos e que eu morava numa casa e os proprietários eram meus amigos brancos. (Sara, ambígua)

Que todas as famílias negras, todos os negros que tinha moravam em casa de aluguel, de preferência em cortiços [...], todas as pessoas que moravam na rua de aluguel eram negras, e os brancos tinham casa própria. Não que os brancos fossem aburguesados nada, mas que tinha uma condição. (Samuel, branco)

Esses trechos, já citados para exemplificar a associação entre brancura e propriedade, demonstram também que apenas a condição socioeconômica ou a raça, consideradas isoladamente, não foram suficientes para explicar as diferenças percebidas num mesmo bairro.

As mínimas distinções expressas nesses depoimentos revelam que, nesta pesquisa, considerar a condição socioeconômica como responsável pela harmonização das relações entre negros e brancos, ignorando processos de elaboração de fronteiras internas na categoria pobre, seria desconsiderar o modo como os próprios indivíduos construíram a percepção de tais condições tendo a raça como referência. Em outros termos, nos depoimentos aqui tratados, brancos pobres não só tinham a brancura a seu favor, mas também eram economicamente privilegiados quando compararam suas situações àquelas vividas por vizinhos que eles reconheciam como negros. Disso decorre que a harmonização das interações raciais em consequiência das condições socioeconômicas, como sugerido por Samuel, foi lembrada apenas por negros que se definiram classe média no contexto da infância e juventude, indicando que, em se tratando dos docentes entrevistados, imbricações entre condições econômicas e raça foram fatores de amenização do racismo apenas quando favoreciam os negros, como será discutido no capítulo seguinte. Fato que pode ter contribuído para que nos relatos sobre discriminação racial elaborados pelos sujeitos da pesquisa não estivessem presentes apenas os brancos filhos de liberais, mas sim brancos pobres cuja posição lhes permitia mobilizar ideias de raça e pobreza para caracterizar vizinhos negros:

Era sempre assim, eu via o negro, a questão do negro, era sempre aquela família pobre, discriminada, ou morava na favela. [...] Na minha casa, essa questão do negro era sempre aquela coisa, o negro era aquele ser estranho, aquela pessoa que você tem sempre que ficar de olho nele, ou ele tem [usa tempo verbal no presente] aquele estereótipo de bandido, de marginal, é sempre aquela família de negro que mora na rua, era a família mais pobre, mais pobre, mais discriminada, isso dentro de casa. (Samuel, branco) 
Fronteiras econômicas e raciais, em quase todos os depoimentos, não apenas se sobrepuseram, mas se influenciaram e se reforçaram mutuamente, corroborando as conclusões de Piza de que "as fronteiras entre brancos e negros são sempre elaboradas e contraditórias" e "há, em qualquer classe, um contexto de ideologia e da prática da supremacia branca" (PIZA, 2002, p. 42). Considerando as entrevistas discutidas, acrescentaria que, na elaboração de tais fronteiras, a classe mencionada por Piza não apenas ocupa papel fundamental, mas ela própria é condicionada pela raça, já que numa mesma classe social são criadas novas distinções que fazem coincidir pertença racial e condições socioeconômicas consideradas favoráveis, em se tratando de brancos, e desfavoráveis, em se tratando de negros.

A reelaboração de fronteiras de classe e raça também remete à construção dos significados de ser branco, num duplo processo de diferenciação: o primeiro, mais evidente nas comparações entre brancos de elite e brancos pobres, sugere uma distinção interna no que se considera ser branco. Essa distinção seria responsável por diferenças entre o racismo expresso por brancos pobres e ricos, implicando que ser branco pobre é ser racista cordial; o segundo se relaciona à construção de fronteiras entre brancos pobres e negros pobres, evidenciando como a condição socioeconômica favorecida e a brancura foram contrapostas à negritude e à pobreza.

Ambas as fronteiras - internas e externas - da brancura problematizam a relação desta com o poder. Comparados à elite, brancos pobres estariam na mesma condição de outros grupos - nordestinos, negros e homossexuais -, mas comparados a negros pobres, brancos pobres estariam em condições de mobilizar a raça e a suposta superioridade relacionada à raça branca instituindo relações de poder favoráveis para si mesmos.

Tendo em vista que a classificação racial no Brasil depende de fatores que extrapolam as características físicas, duas dúvidas emergem das análises realizadas: a categorização como negro de pessoas que, entre pobres, viveriam em condições ainda menos favoráveis se comparadas às vividas por vizinhos brancos, teria relação com as significações que atrelam negritude e pobreza? Em oposição, as associações entre brancura e propriedade e entre brancura e melhores condições socioeconômicas, tal como explicitado anteriormente, seriam responsáveis pela percepção de que, entre pobres, aqueles com melhores condições socioeconômicas seriam brancos? Perguntas que podem ser sintetizadas numa única indagação: se o dinheiro embranquece, a pobreza faz o oposto? 
Buscando problematizar essas indagações, no capítulo seguinte avanço as análises a respeito das fronteiras internas na condição de brancos, uma vez que raça, gênero e condição socioeconômica não foram os únicos fatores mencionados pelos docentes como aspectos relevantes de diferenciação entre brancos e que outras características sociais foram apontadas como significativas nesse sentido. 


\section{Aproximação e distanciamento dos significados de ser branco}

Ao deslocar a ênfase de análise dos sujeitos brancos para os significados de ser branco - da brancura como característica aparente para a brancura como um valor -, foi possível perceber dois movimentos recorrentes nas falas de pessoas que se classificaram racialmente de maneiras diferentes. O primeiro deles consistia na crença de que algumas pessoas fenotipicamente brancas se afastariam da brancura em consequência de não apresentarem condições de vida condizentes com os valores atribuídos a ela. O segundo movimento se baseava na ideia de que os significados de ser branco poderiam ser mobilizados por pessoas negras em situações e contextos variados através do branqueamento.

No levantamento bibliográfico que realizei em estudos empíricos brasileiros, encontrei poucas referências sobre a dificuldade de pessoas brancas para acessarem os valores associados à sua pertença racial, ou às maneiras como outras posições sociais ocupadas por elas interferem na definição de seu status racial. O mais comum são estudos que se debruçaram sobre o processo de branqueamento e o ilustraram ricamente. Exceção a esse quadro foi brevemente apresentada por Freyre (2006 [1936]) em trabalho teórico, que contrapondo o processo de ascensão sociorracial do mulato à situação de brancos pobres, destacou:

[...] encontram-se brancos no Brasil - brancos, quase brancos e até loiros - que desceram de classe, em vez de conservarem a origem; e são hoje os "brancosos", ou os "amarelos", os "come-sapo-com-banana", tão desdenhados pela gente de classe inferior, de cor mais carregada que a deles. Como a maioria dos negros, dos mulatos e dos caboclos mais escuros, eles moram em mucambos: em casas todas de palha ou cobertas de palha como as da África; comem com os dedos em cuias à maneira dos índios e dos negros, andam descalços (FREYRE, 2006 [1936], p. 802 , grifos meus).

Esse excerto, no contex to do qual foi retirado, presta-se à comprovação por parte do autor de que em nosso país seria possível passar de uma classe a outra, de uma raça a outra e de uma região geográfica desvalorizada a uma valorizada, por meio do esforço pessoal ou da falta dele, possibilidade que não se verificaria em nenhuma outra parte do mundo e conferiria peculiaridade a nossas relações sociais pela ausência de linhas de raça e/ou de restrições baseadas na raça. Nesse trecho, pobreza e costumes associados a ela são apontados como características que promoveriam a decadência de classe para brancos. Note-se que o autor não se refere a um processo de decadência racial, que seria o 
movimento esperado em contraposição à "ascensão do mulato para branco", tese central de Sobrados e Mucambos (GUIMARÃES, 2000b).

Os brancos citados por Freyre continuaram a ser percebidos como brancos, mas foram adjetivados pejorativamente de modo a salientar a incoerência entre sua cor e suas condições socioeconômicas, próximas às condições vividas por negros e mestiços mais escuros.

Embora essas ideias de Freyre se referissem a contexto sócio-histórico distinto e se prestassem à comprovação da imagem já superada do Brasil como uma democracia racial, baseei-me parcialmente nelas para elaborar a hipótese de que significados de ser negro e branco poderiam ser mobilizados por indivíduos de diferentes pertenças raciais quando em conjunto com outras posições sociais - privilegiadas ou subordinadas - vividas pelos sujeitos.

Todavia, ao contrário do que propôs o autor, considerei em minha reflexão que o trânsito desses significados não seria evidência de relações raciais democráticas, mas reforçaria hierarquias baseadas na raça, uma vez que os significados de ser branco e negro são não apenas opostos, mas hierarquizados, já que o acesso aos primeiros é, em geral, encarado como um processo de ascensão sociorracial e a mobilização de significados de ser negro seria responsável pelo oposto.

Desse modo, analisei os depoimentos à procura de incoerências entre corpo, mais especificamente a cor autoatribuída, e os significados raciais descritos e analisados no capítulo anterior, procurando compreender como pessoas que se descreveram como brancas se afastaram de tais significados, chegando até mesmo a modificarem sua classificação racial em função desse distanciamento. E o movimento contrário: quando negros cultivaram comportamentos atribuídos aos brancos.

Argumento nas reflexões posteriores que processos de branqueamento e enegrecimento não se completam nem do ponto de vista dos sujeitos, nem da perspectiva das pessoas com as quais eles tiveram contato, mas podem ser apontados como contextuais, ou seja, ser branqueado ou afastar-se da brancura, mesmo sendo fenotipicamente branco, é condição situacional construída com base na percepção de fatores que conjugam aparência, condições socioeconômicas e comportamentais socialmente valorizadas ou desvalorizadas. 


\subsection{Menos brancos? - Posições subordinadas e o acesso aos significados de ser branco}

Nas entrevistas de pessoas que declararam terem sido reconhecidas como brancas em alguns contextos, e que oscilaram em sua classificação racial, emergiram memórias associadas a outras posições subordinadas ocupadas por elas que se referiam à origem regional, doenças e características físicas estigmatizadas. É o caso de Sara, que declarou que viver em condições socioeconômicas muito próximas às de colegas negros, ter uma aparência ambígua e um comprometimento físico - a falta de um dente - foram características importantes para que ela se classificasse como negra e se solidarizasse com as dificuldades enfrentadas por colegas que pertenciam a esse grupo racial, mesmo sendo socialmente reconhecida como branca ou morena:

Eu acho que durante a adolescência eu também fui motivo de piada, porque eu não tinha um dente. Você imagina uma adolescente banguela? $\hat{E}$ uma coisa muito difícil de você lidar com isso. Então essa questão da discriminação sempre foi uma coisa que me marcou muito individualmente e coletivamente. Individualmente por causa da, menos da minha negritude, muito menos, eu acho que poderia ter ficado do lado dos brancos tranquilamente. Até por que essa história de "eu sou mais exótica do que negra", sempre me viram assim. [...] Eu não fiquei por conta dessas outras características que eu tinha, de origem, de ter uma condição de vida muito difícil mesmo, então e, portanto, eu sempre transitei nos lugares onde as pessoas tinham essa mesma condição e tinha uma maioria negra, eles eram os meus amigos e depois porque fisicamente eu tinha um comprometimento, eu não tinha um dente. Eu me tornei muito sensível a essas coisas. (Sara, ambígua)

A docente apontou características socialmente desvalorizadas como fatores que a distanciaram da classificação racial como branca, classificação que ela poderia ter escolhido, mas que fora recusada tendo em vista marcadores físicos e sociais que a tornavam sensível à discriminação. Entre esses marcadores, a aparência ambígua, produto da miscigenação, foi apenas um dos elementos acionados; outras características tomadas como comprometedoras - a pobreza, a falta de um dente, residir na periferia - a afastavam de condições que ela acreditava serem relevantes para caracterizar-se branca.

Márcio (branco) e André (ambíguo) também citaram suas condições socioeconômicas adversas, a mestiçagem e as experiências com o preconceito como determinantes para seus posicionamentos frente à própria pertença racial. Para Márcio, a doença estigmatizante do pai - portador de hanseníase - e a pertença racial de parentes próximos - o avô e a mãe do entrevistado eram negros - foram fontes de desconforto diante dos conflitos raciais observados. Segundo ele: Eu não gostava das coisas que aconteciam, quando maltratavam alguém por questão da cor eu sentia como se estivessem 
maltratando minha mãe ou meu avô. Além dos conflitos relacionados à raça dos parentes próximos, Márcio também relembrou situações nas quais era alvo de xingamentos, principalmente no contexto escolar, indicando que não apenas sua origem mestiça suscitava incômodos diante da discriminação racial, mas que sua posição em relação aos amigos da escola não lhe permitiu associar sua brancura à maior possibilidade de aceitação:

Lembro que as meninas xingavam muito de veado. A escola fervilhava em termos de xingamentos, era para todos os lados. Eu era um dos alvos, eu ignorava, fazia de conta que não era comigo.

Do mesmo modo, André relatou episódios nos quais foi discriminado devido a sua origem regional:

[...] na comunidade tem muito negro, a maioria descendente de nordestinos, eu sou nordestino. Quando nós chegamos aqui tinha um menino chamado Osvaldo, a família dele toda negra com muitos baianos também, e tinha um pouco de preconceito mesmo. Eu sofri preconceito pelo fato de ser baiano, como eu acho que nunca tive um enfrentamento, superei assim com bola pra frente, eu aprendi que isso nunca me marcou negativamente. Hoje as pessoas que agem dessa maneira comigo eu enfrento, mas nesse momento eu...

As oscilações na condição financeira vividas por André, assim como no caso de Sara, fizeram com que, já em São Paulo, ele fosse morar na periferia numa comunidade com muitos negros e nordestinos, grupos que tinham em comum marcas que os tornavam mais suscetíveis à discriminação. Além disso, Sara e André se lembraram de que a pobreza impedia seu acesso à propriedade, uma característica associada à brancura, como indicado em item anterior. Se ser branco significava possuir boas condições financeiras, ser respeitado em sua individualidade, ser considerado bonito e inteligente, as condições de vida de Sara e André não se ajustavam a sua aparência física e origem regional.

Interessante salientar que entre os três professores que relataram experiências de subordinação diferentes da racial, Sara e André classificaram-se como negros, ele em momentos pontuais de sua fala e ela ao longo de toda a entrevista, indicando que outras posições sociais, além da mestiçagem, também foram relevantes na definiç̧ão de seu pertencimento racial. Tendo em vista a ideia de brancura como possibilidade de aceitação social, fica a indagação: as características desvalorizadas desses docentes os afastavam da aceitação e, consequentemente, da condição de brancos?

Em contrapartida, aqueles autodeclarados brancos que não fizeram alusão a momentos em que fossem discriminados em razão de fatores como os acima descritos, 
caso de Vitória e Samuel, foram os únicos a lembrar os privilégios do reconhecimento social de sua brancura, mencionando não apenas uma brancura descorporificada, característica de terceiros, mas falando a respeito de suas experiências vantajosas como brancos, como já discutido anteriormente:

Eu não vou falar que eu não tenho vantagens, eu tive muitas, muitas de ser branca, eu tive assim... Eu pude dar aula nas melhores escolas de São Paulo. Eu tive assim, lógico como branca, eu tive todas as portas abertas, mesmo que fosse uma portinhola que eu tivesse que ficar de quatro, mas a porta estava aberta para mim. E eu tenho certeza que essas mesmas portas pra alguém que fosse negro, do mesmo jeito esse negro precisaria ter o triplo ou o quádruplo do que eu tive. (Vitória, branca)

Eu via que eu era mais aceito que os outros. Isso não vou dizer pra você que não é, né?[...] Então, eu sempre via a questão do branco, de ser branco, eu sempre via como uma questão de aceitação, eu sempre era mais aceito. Qualquer coisa que acontecia, a culpa era do menino negro, a culpa era disso aí. Eu via que numa sociedade eu tinha uma aceitação. Igual o outro, né? a sociedade, a idealização da sociedade que você tinha, era de uma sociedade branca, que é ainda hoje, né? Se hoje é assim você imagine na época. (Samuel, branco)

Nesses trechos, ser branco significou ser aceito e ter acesso a vantagens. As vantagens citadas por Vitória diziam respeito à ocupação de cargos de professora em escolas particulares, vagas majoritariamente ocupadas por pessoas brancas. Já para Samuel a aceitação social fora citada como a principal consequência de seu reconhecimento social como branco.

Essas passagens foram seguidas de comparações com as condições vividas por pessoas negras. Vitória salientou que se fosse negra teria de apresentar três ou quatro vezes mais qualificações para ocupar a mesma vaga de emprego. Samuel exemplificou as limitações de trânsito impostas a seus colegas negros, sempre parados pela polícia ou os primeiros a serem interpelados em casos suspeitos, limitações que ele não experimentava em virtude de sua pertença racial. Essas comparações indicam que, para esses docentes, a percepção do próprio conforto ou vantagem esteve vinculada à percepção do desconforto ou desvantagens vividas por negros.

André discorreu sobre o mesmo tema, porém nunca o relacionou a suas próprias experiências. Perguntado sobre o que significou para ele ser reconhecido socialmente como branco, disse:

Na verdade eu tenho até dificuldade de aceitar essa possibilidade de você é um grupo, eu sou outro. Mas, para um menino da sala, ele ser branco, ele significa, por exemplo, as pessoas vão aceitar ele mais, e o negro, 
isso aí eu consigo observar, ele, de alguma forma, ele acaba aceitando um lugar que ele não deveria aceitar pra ele. (André, ambíguo)

André atribuiu a outros o significado de ser branco - aos alunos - distanciando-se deles. Ele alegou dificuldades em classificar as pessoas racialmente e atribuiu pouca relevância ao seu reconhecimento social como branco, o que pode ser compreendido tendo por base a negação de sua brancura, como descrito em capítulo anterior, bem como o contexto em que tal declaração foi elaborada, já que a frase denota o esforço por demonstrar que não via a pesquisadora como parte de um grupo diferenciado - eu tenho até dificuldade de aceitar essa possibilidade de você é um grupo, eu sou outro. Porém, o docente admitiu que para seus alunos a brancura fosse um privilégio, vivido no mesmo sentido daquele apontado por Samuel e Vitória: brancura como sinônimo de aceitação.

Fica a dúvida se, e em que ocasiões, o reconhecimento social de André como branco lhe conferiu vantagem semelhante, já que a interferência de sua origem regional pode ser tomada como contextual, bem como as demais subordinações relatadas por brancos. A pertença a um grupo estigmatizado - os nordestinos - só passou a fazer sentido para André a partir da migração para São Paulo. A doença socialmente desvalorizada e a raça dos familiares de Márcio puderam ser omitidas em contextos nos quais não era conveniente mencioná-las. Sara resolveu o problema que marcou sua adolescência - a falta de um dente - quando teve oportunidade financeira para isso. Mesmo a pobreza vivida por Sara e André, descrita como marcante, não foi experimentada antes da migração para São Paulo e não se verifica atualmente.

Se considerarmos a cor como variável dependente de outras características sociais, tal como propõe Piza e Rosemberg (2002), assim como a classificação racial contextual no Brasil, é possível aventar a hipótese de que as variações de classificação racial verificadas nos depoimentos de André e Sara, nos diferentes espaços sociais e geográficos que ocuparam, ora os aproximavam da brancura ora os afastavam dela. Não sugiro, contudo, que esses sucessivos distanciamentos e aproximações da classificação como branco, negro ou moreno foram escolhas individuais, mas classificações (e por que não dizer identidades?) assumidas em situações em que ambos experimentaram o preconceito e a pobreza ou em que acessaram condições socioeconômicas favoráveis.

Essa maleabilidade classificatória, no entanto, não esteve disponível para pessoas com tonalidade de pele mais escura, como discutido no capítulo três. Carolina, 
percebendo as diferenças entre as subordinações baseadas na classe social e na regionalidade e aquelas relacionadas ao racismo, concluiu:

É diferente para o branco ser discriminado uma ou outra vez, aquilo vai ser... Mas quando você tem a sua vida inteira de discriminação, de preconceito, de ser colocada no último lugar, ser passada pra trás, ai! (Carolina, negra)

O desabafo de Carolina pode ser compreendido diante da diversidade de relatos de discriminação racial presente em seu depoimento. Nesses relatos, independentemente de outras posições ocupadas pela entrevistada - baiana, filha, professora, esposa, estudante etc. -, sua condição racial foi sempre lembrada; daí todas essas posições serem mencionadas tendo a pertença racial como referência: ela era uma negra baiana, professora negra, única filha negra entre irmãos reconhecidos socialmente como brancos, aluna negra numa escola majoritariamente branca, definições que não partiram apenas de sua autoidentificação, mas do tratamento dispensado a ela nessas diferentes instituições e espaços sociais.

Quanto aos ambíguos, indicaram a existência de fronteiras internas na brancura que poderiam dificultar o acesso a alguns dos significados e vantagens a ela atrelados. Essas fronteiras indicam intersecções entre raça e outras posições sociais para além do trinômio classe-raça-gênero: nos casos aqui tratados, a origem regional, doenças e características físicas desvalorizadas.

Se esses traços distanciam fenotipicamente brancos dos significados atribuídos à brancura, supostamente problematizando sua classificação racial como brancos, o contrário também seria possível: fenotipicamente negros se afastariam de sua pertença racial ao distanciarem-se dos significados de ser negro, notadamente aqueles imersos na ideologia racista. Esses negros, sujeitos ao ideal de branqueamento na opinião dos entrevistados, ocupariam, ainda que de maneira precária, lugares sociais considerados peculiares aos brancos, demonstrando que as construções racializadas não só opõem negros e brancos, mas que, mantidas as hierarquias, tornam possível o cultivo de valores associados ao grupo racial branco por parte de negros. Esses negros branqueados teriam no branco uma imagem ou um valor a ser seguido, deixariam de:

[...] viver a sua vida para viver num espelho, uma imagem, pensando que aquela imagem é mais bonita, melhor do que a sua, viver numa eterna prisão. É a imagem de uma pessoa branca, a imagem do europeu, dos gringos, como se fala. (Carolina, negra) 
Interessa-me aqui analisar quais seriam as características desse reflexo: quando um negro se olha no espelho e vê a imagem de uma pessoa branca, que imagem é essa? Que elementos se associam a ela? Que significados de ser branco seriam mobilizados por negros branqueados? Como se verá nas considerações posteriores, apesar de os significados de ser branco estarem além do corpo propriamente dito, verificando-se, principalmente, em características de comportamento, existiriam sujeitos legítimos para mobilizar tais significados e a avaliação de quais seriam esses sujeitos estaria embasada em sua aparência física. Nesse sentido, o corpo seria um elemento central para determinar não só quem é negro e quem é branco, como quem pode ou não acessar os significados de ser branco sem ensejar críticas e avaliações acerca da adequação entre sujeito, corpo e significados raciais.

\subsection{Quase brancos? - posições privilegiadas e o acesso aos significados de ser branco}

Os depoimentos dos dez sujeitos desta pesquisa traziam considerações a respeito do processo de branqueamento ${ }^{21}$, processo que pode ser interpretado em três sentidos diferentes: branqueamento genético, proposto a partir de políticas de caráter eugênico em fins do século XIX e início do século XX, no Brasil; o branqueamento social ou econômico, condicionado pela ascensão social e o acesso a serviços e espaços majoritariamente, quando não exclusivamente, frequentados por brancos, ou disponíveis a eles; e o branqueamento estético, marcado pela manipulação do corpo e do cabelo crespo para aproximar-se do ideal branco de beleza (DOMINGUES, 2002).

As considerações a respeito do branqueamento por meio da miscigenação foram realizadas no capítulo três, mais especificamente nas análises sobre o papel da mestiçagem na classificação racial dos sujeitos desta pesquisa. Neste item procuro analisar as falas relacionadas ao branqueamento socioeconômico e estético. Este último se materializa nas tentativas de manipulação do corpo negro para uma suposta adequação ao padrão branco de beleza, indicando uma estratégia de aproximação de uma das dimensões da brancura analisada no terceiro capítulo: brancura localizada no corpo, mais especificamente no fenótipo, estratégia facilmente caracterizada pelos docentes, já que sua existência seria verificável por meio da observação direta de corpos negros. Porém, este foi um

\footnotetext{
${ }^{21}$ Conceito aprofundado no Capítulo I.
} 
procedimento pouco comentado pelos entrevistados de modo geral, independentemente de sua pertença racial.

As tentativas de branqueamento estético foram descritas em tom de censura e lembradas de forma mais detalhada por mulheres negras cujas próprias experiências serviram de base às críticas formuladas, como ilustram os trechos abaixo:

Então, eu acho que eu aceitei essa imposição [de alisar o cabelo] pra não sofrer tanto talvez. (Sandra, negra)

Quando fizesse 18 anos queria ver parar de mexer no meu nariz, porque minha mãe tinha mania, quando eu chorava, eu levantava assim o nariz, ela dizia "seu nariz vai ficar chato, vai ficar mais chato ainda, o nariz que o boi pisou, não faça isso com o seu nariz". [...] E eu tinha pavor de alisar cabelo. Primeiro começou com aquela chapinha que colocava no fogo [...] ai, aquilo puxava! Tinha horror daquela chapinha. Geralmente quando você faz aquela chapinha fica bonito o cabelo balançava, depois entrava no rio, entrava no mar molhava aquele negócio, ressecava aquele troço, ruim pra caramba. (Carolina, negra)

O alisamento dos cabelos foi encarado por Sandra como uma imposição, possivelmente condicionada pela existência de um padrão branco de beleza unanimemente citado pelos entrevistados.

Essa mesma imposição foi atribuída por Carolina aos seus familiares, parte deles categorizados como brancos, e sinalizava que a idealização do cabelo liso como norma ou condição para a beleza feminina suscitava os momentos de alisamento dos quais a docente declarou sentir pavor e horror. Não apenas o cabelo crespo, mas também o nariz chato eram alvos de controle por parte da mãe de Carolina, que acreditava que determinadas formas de tocar o nariz o tornariam mais caracteristicamente negro. A docente avaliou a imposição familiar para que alisasse seus cabelos não apenas como indicativa de aceitação do padrão de beleza branco, mas como tentativa de minimizar o contato com situações de preconceito e discriminação racial, indicando que, na educação de crianças e adolescentes negros, a mudança de seus corpos para a adequação a um modelo de estética branca poderia estar relacionada à estratégia de proteção familiar contra sofrimentos ensejados pelo contato com o racismo:

Acho que isso daí acontece muito com criança, com adolescente, você percebe que os pais já começam a fazer com que as crianças mudem, não criem sua própria personalidade. Como eu, pô, por que minha mãe alisava tanto meu cabelo, minhas tias? Porque não queriam que eu sofresse o que o negro sofre: discriminação. Sofre preconceito. 
A fala de Carolina sugere que o branqueamento estético se configuraria em possibilidade de acessar uma das características associadas à condição de ser branco projetadas para além do corpo: não ser alvo de preconceito. Se, como mencionado por André (ambíguo), ser branco é confortável, porque ele está numa situação confortável, ninguém é preconceituoso com ele ${ }^{22}$, crianças e adolescentes negros submetidos a processos de aproximação de suas características físicas à brancura estariam menos sujeitos ao sofrimento causados pela discriminação e preconceito.

Todavia, há que se salientar a ineficácia da estratégia acima mencionada tendo em vista a quantidade de relatos de situações de discriminação racial vividas por Carolina durante a infância e juventude e que se encontram discutidos ao longo deste texto.

Não apenas o corpo, mas determinadas condutas e posturas relacionadas à brancura seriam mobilizadas por negros branqueados. Novamente Carolina, avaliando esse processo como sendo uma imitação, destacou que, ao se branquearem, negros se espelhariam na

Imagem de uma pessoa branca, a imagem do europeu, dos gringos, como se fala lá, que é aquele nariz afinado, cabelinho bem liso penteado, são as roupas muito discretas, porque baiano, negro, gosta de muita coisa colorida, gosta do brinco, gosta da pulseira, gosta dos balangandãs e, não, tem uns que se retraem em tudo isso e quer copiar a imagem do branco e você sente que a pessoa é meio reprimida, fica naquelas...

Embora se refira a negros branqueados, a citação de Carolina apresenta descrições de características que seriam peculiares ao branco europeu e que transcendem a dimensão corporal do branco, ao fazer alusão à preferência desse grupo racial por roupas discretas, predileção que também se verificaria por parte de negros ciosos de sua inserção na brancura.

Num movimento semelhante, outros entrevistados se referiram de forma mais explícita ao branqueamento socioeconômico. Este foi descrito de maneira ambígua dependendo da classificação racial do falante. Brancos formularam suas críticas de maneira mais direta que negros e estes, por sua vez, problematizaram o branqueamento socioeconômico tendo em vista suas próprias experiências de ascensão social. Os professores definiram o branqueamento nos seguintes termos:

Embranquecido socialmente é aquele negro que... São os negros que estudam na escola particular, mas só têm amigos brancos, assim: "Eu não tenho problemas com negros, mas eu não tenho nenhum amigo negro, só tenho amigos brancos". (Vitória, branca)

\footnotetext{
${ }^{22}$ Note-se que a generalização expressa nessa fala não correspondeu às experiências descritas por docentes autoclassificados brancos em momentos particulares ou em todo o processo de pesquisa.
} 
Eu estou numa comunidade negra e na comunidade negra não me reconhecem porque eu não sou uma expectativa dos negros, eu sou uma expectativa de uma família branca de classe média [...] Você veja, eu falei como africano? Falei como um afrodescendente? Eu falei como um europeu. (Cláudio, professor negro, que concluiu duas graduações, duas especializações e um mestrado em Educação)

Quando eu falo da questão do embranquecimento, de uma sociedade assim, é você não ter uma tomada de consciência daquilo que você é. [...] Se você pegar um exemplo, um negro no Brasil, quando ele sobe na vida, ele sai desse processo, dessa tomada de consciência, então ele fica mais do lado do branco do que do próprio negro. Não vou dizer que ele precisa curtir jazz, ir ao candomblé, precisa sambar, pra falar que é negro, mas ele passa... Essa tomada de consciência que nós temos aqui [no curso] ele não tem: pra ele não tem racismo. Então é o seguinte, a partir do momento em que eu estiver no mesmo patamar que o branco eu não me preocupo mais com o negro. [...] Então, o processo de embranquecimento ele se dá na economia, se dá na cultura, nas novelas, você vê na ideia da televisão em si, da mídia. (Samuel, branco)

Nesses trechos foram citados diferentes fatores que desencadeariam o processo de branqueamento: a ascensão socioeconômica, que afastaria negros de outras pessoas de seu grupo racial e do combate ao racismo; o acesso à escolarização, que seria responsável por uma europeização de comportamentos e modos de expressão; a adesão a um modo tipicamente branco de vida, que excluiria comportamentos e elementos culturais relacionados à negritude. O processo de branqueamento socioeconômico foi mencionado pelos próprios entrevistados negros em diversos momentos e, por vezes, funcionou como possibilidade de defesa frente à discriminação racial presenciada em diferentes contextos, como ilustra o trecho abaixo, referente à vida escolar de Cláudio:

A grande maioria dos meus colegas da primeira à quarta série já não estava mais no ginásio. Ficaram na quarta série, paravam, eram expulsos, né? E tinha uma relação interessante, que quando a gente ia pra diretoria, que eu aprontava, quando ia pra diretoria, a relação era que meus pais eram presentes na escola, então geralmente alguma punição, suspensão, era em menor grau pra mim, mas para os meus companheiros muitas vezes motivava até a desistir de estudar. [Pesquisadora: Que tipo de punições?] Suspensão, a humilhação dentro da sala de aula... Coisa que hoje a gente não vê. [risos] Era humilhação em torno de eles serem negros, terem uma condição social menor. E eu não, eu era negro, mas eu tinha sempre tênis novo, roupa nova, meus pais apareciam nas festas, reunião de APM [Associação de Pais e Mestres]. Então era assim, eu era uma classe média e eu não sabia. (Cláudio, negro)

Na frase eu era negro, mas eu tinha... A conjunção adversativa mas estabelece uma relação de oposição entre a pertença racial estigmatizada e a posse de objetos 
valorizados no contexto escolar frequentado pelo docente. Sua condição social pareceu compensar sua negritude. Mas também sugere a excepcionalidade do fato de um aluno negro possuir tênis e roupas novas. Ser exceção à regra, mesmo que essa regra estivesse conformada por estereótipos ou preconceitos, foi apontado por Cláudio como maior probabilidade de distanciar-se dos castigos e humilhações aos quais estavam sujeitas outras crianças negras de condição social menor, situações que algumas vezes culminavam em evasão escolar.

No entanto, ainda que tenha recebido tratamento diferenciado daquele dispensado a outros colegas negros, a pertença racial de Cláudio não deixou de ser mencionada. Ele era um negro diferente dos demais, mas continuava a pertencer a esse grupo racial, daí que fosse preciso compensar tal posição por meio de elementos que podiam ser acessados tendo em vista sua situação econômica privilegiada.

Cláudio se lembrou de vários episódios de preconceito racial, vividos tanto na comunidade quanto no ambiente familiar, indicando que a suposta amenização de sua condição racial propiciada pelo status socioeconômico nem sempre foi alcançada. Se o ditado popular "o dinheiro embranquece" sugere o acesso à brancura por meio da ascensão econômica, o relato de Cláudio - mesmo professor que se declarou culturalmente branco, segundo ele, em virtude de sua maneira europeizada de falar - revelou que o acesso a uma cultura considerada não apenas branca, mas europeia, não equivaleu a ser tratado como branco. Contrariando essa interpretação, Carolina salientou que

Ser branco deve ser muito bom, viver no meio de brancos deve ser também muito bom. Mas, hoje em dia, eu tenho consciência que não é assim também, no nosso país as coisas não são assim. Porque se você for negro e tiver dinheiro você vai ser tratado como um branco, logo vão te clarear, você não vai ser tão negro assim, começa a ficar branquinho, "Ah, você é clarinho" e começa aquela coisa de ir clareando, de branqueamento.

$\mathrm{Na}$ opinião da entrevistada, viver em meio a brancos e ser tratado como igual seria uma consequiência da condição socioeconômica favorável. Negros com maior poder aquisitivo seriam tratados como brancos, de onde se subentende que esse tratamento seria melhor do que aquele dispensado a negros em geral. No entanto, estudos que levaram em conta a opinião de entrevistados negros que ascenderam socialmente demonstram justamente o contrário: a percepção do racismo torna-se mais arguta à medida que se ocupam espaços sociais privilegiados (FIGUEIREDO, 2004). 
Para Cláudio, que considerou sua trajetória educacional e financeira como ascendente, o fato de ocupar espaços tradicionalmente acessíveis a brancos transformou-se em fonte de desconfortos:

[...] eu percebi que eu era um negro culturalmente branco e que eu não conseguia resgatar o negro em mim, nem dentro da minha família, porque a minha família toda miscigenada queria ser branca e a minha família negra queria ser branca, ninguém da minha família branca queria ser negro, e você vê hoje muitas pessoas brancas querendo assumir uma identidade negra, uma maneira de falar... Na minha época não tinha nada disso e eu comecei a perceber que eu não estava onde eu poderia estar. Eu não tenho nada que defender dos brancos, então por mais que eu estude, por mais que me especialize eu não tenho espaço na comunidade branca. [...] Eu estou na comunidade negra e na comunidade negra não me reconhecem, porque eu não sou uma expectativa dos negros, eu sou uma expectativa de uma família branca de classe média. Se eu fosse branco, outra conotação, se eu fosse negro e não tivesse nada disso, acho que a minha família ia ter uma outra relação comigo, porque o tempo todo eu fui, sem querer, sem querer sair da questão de ser negro, eu fui me tornando branco, sem querer, me tornando branco, porque não havia necessidade.

A extensa fala de Cláudio carrega em si as contradições da associação de determinados comportamentos à raça, branca ou negra. Em primeiro plano encontra-se a ideia de que estudar, falar como europeu e se especializar são ações relacionadas à brancura, já que ao efetivá-las o entrevistado ocuparia um espaço onde não deveria estar em razão de sua pertença racial. Por outro lado, mesmo estando em vias de concluir pesquisa de mestrado sobre a implementação da Lei 10639/2003 e de ter participado de vários cursos, debates e palestras acerca da questão racial, Cláudio se acreditava distante das expectativas de sua comunidade, expectativas não explicitadas por ele.

A posse de elementos associados à brancura, neste caso, diplomas de nível superior e de pós-graduação, conferiu a Cláudio a ocupação de um não-lugar, um espaço vazio entre ser negro e ser branco, não podendo ser membro nem de um grupo nem de outro, uma vez que ele seria culturalmente branco, mas fenotipicamente negro. A incoerência entre o corpo e os significados sociais por ele mobilizados condicionaria a ocupação desse nãolugar.

Sem espaço na comunidade branca e sem reconhecimento na comunidade negra restou a Cláudio buscar elementos socialmente convencionados como negros positivamente significados, como o engajamento em movimentos antirracistas, a busca por valores considerados africanos e o resgate da ancestralidade africana, de modo a resgatar $o$ negro que ele acreditava ter perdido sem querer. 
Esse mesmo desconforto foi expresso por outros docentes negros que haviam experimentado uma trajetória escolar ascendente em relação à família de origem. Roberto, graduado em Filosofia e mestre na mesma área por universidade pública, avaliou a dificuldade de ocupar espaços socialmente percebidos como brancos:

[...] em São Paulo a coisa muda de figura, você está numa cultura hegemônica europeia em que os espaços são realmente bem delimitados, e vocês... Dificultam a sua entrada em determinados espaços, se você não conquista de forma bem dura, se você não batalha de forma bem dura, essa dificuldade pode ser impeditiva. E às vezes desconcertante, você está no meio de... Que você percebe que você chama atenção, é um diferencial ali, causa espanto, às vezes é desconcertante isso. E tem uma outra coisa na questão de São Paulo. São Paulo os negros se manifestam mais assim em guetos, a manifestação é mais em guetos, o pessoal do rap, das galerias e sei lá o quê. Então se você tem uma... Se você não gosta muito de rap, se você não é muito ligado a samba, se não milita na política racial, eu não sei, você fica meio sem lugar. (Roberto, negro)

Roberto, cuja família era percebida como rica na pequena cidade em que viveu na infância, iniciou sua entrevista dizendo que a questão do racismo não aparecia, até porque se não quisesse andar com negros na Bahia ia ter problemas. E porque morava também num local onde muita gente com poder aquisitivo maior morava... Indicando que o maior poder aquisitivo e a concentração de negros no bairro eram fatores que diminuíram a incidência do racismo.

Porém, ao mudar-se para São Paulo, o docente experimentou o preconceito racial de maneira mais explícita. Exposto a uma cultura hegemônica europeia e sem a participação em atividades que, de acordo com sua interpretação, aglutinariam negros paulistanos - samba, rap, militância racial - o entrevistado também acreditava ficar meio sem lugar, não participando integralmente de nenhuma comunidade.

Note-se que ao falar a respeito dos paulistas e suas atitudes discriminatórias, Roberto incluiu-me nesse grupo por meio do uso do pronome vocês, evidenciando que nossa relação não se construía apenas a partir de hierarquias de gênero, raça e escolarização, mas que naquele contexto minha origem regional foi encarada como potencialmente opressora. As menções ao incômodo causado por sua presença em determinados espaços majoritariamente brancos de São Paulo foram contrastantes com suas experiências na Bahia, onde nasceu e cresceu, região em que era mais comum ver negros ocupando todos os espaços, mesmo que fosse em número reduzido. Já em São Paulo, apontou a existência de um apartheid a separar negros e brancos. 
Carolina também destacou que a associação entre brancura e determinados comportamentos e características condicionava questionamentos quanto à legitimidade de negros ocuparem certos espaços e possuírem determinados saberes, conceituados como brancos:

Então ou você cai pra um campo que não é de... Que a sociedade não denomina como espaço de negro ou "Onde você aprendeu, como você aprendeu?". Por exemplo, se você vai fazer uma pesquisa científica, se você vai falar de um determinado assunto, principalmente na área científica, na área médica, aí vão te perguntar: "Mas por que você tem esse conhecimento? Quem te ensinou?" Sabe? Fica te cobrando como se você não tivesse o direito de saber sobre um determinado assunto, de saber fazer determinadas coisas porque são coisas de branco, sabe? É estranho. (Carolina, negra)

Ao fazer alusão a um não-lugar ou à ocupação de um lugar reservado para brancos, esses entrevistados de certo modo contrariaram a tese do branqueamento, já que não indicaram receber tratamento semelhante àquele dispensado a brancos - não terem espaço na comunidade branca - justamente porque continuam a apresentar no corpo as marcas que permitiam sua categorização como negros. Quadro semelhante a esse foi encontrado por Figueiredo (op. cit.), que ao entrevistar empresários negros destacou:

Nas minhas pesquisas, vários entrevistados mencionaram que são olhados com curiosidade e espanto quando participam de atividades sociais relacionadas à classe média, e com desconfiança quando querem adquirir ou desfrutar dos bens sociais e simbólicos associados às pessoas de poder aquisitivo mais elevado (2004, p.1).

Nas considerações da autora sobre os motivos que dariam origem à curiosidade e desconfiança frente a negros que ela classificou como de classe média, esta salientou aspectos relacionados à baixa representatividade de negros em atividades mais prestigiadas, às construções sociais da inferioridade econômica e simbólica negra e à existência de um imaginário que constrói uma incompatibilidade entre a categoria negro e o desfrute de bens associados à modernidade como principais responsáveis pela percepção do negro como estando "fora do lugar" (ibidem, p.2).

A essas conclusões poderiam acrescentar-se as ideias de que o alto poder aquisitivo é pensado não apenas segundo critérios econômicos como também raciais e que a noção de classe média, citada por Figueiredo, seria construída também com base em concepções a respeito da brancura, daí que o "negro fora de lugar", aquele que ascendeu socialmente, teria ocupado "o lugar que o branco considera exclusivamente dele" (BENTO, 2002a, p. $53)$. 
Desse modo, os "bens sociais e simbólicos associados ao maior poder aquisitivo" (FIGUEIREDO, op. cit.) seriam aqueles igualmente associados à brancura. Entre esses bens, a escolarização se apresentou como indicativo mais proeminente de branqueamento se comparada ao poder aquisitivo. A alta escolarização seria peculiar aos brancos e o acesso desses docentes negros à pós-graduação teria sido responsável pela ocupação de uma posição social que parecia não lhes ser legítima ocupar. Carolina formulou reflexão semelhante, mas salientou que a percepção de que negros não teriam o direito de saber sobre um determinado assunto ou fazer determinadas coisas se devia ao estranhamento de terceiros cujas perguntas demonstrariam a crença de que alguns comportamentos e características seriam coisa de branco.

Se graduar-se e especializar-se são indicativos de uma europeização, como propunha Freyre em Sobrados e Mucambos, a lógica que considera o diploma de nível superior uma "insígnia de branco" (FREYRE, 2006 [1936], p. 511) permanece válida na perspectiva de alguns entrevistados. Mesmo no caso de Cláudio, que se dedicava a pesquisas sobre a questão racial numa perspectiva negra, o acesso a níveis elevados de escolarização foi tomado como comprovação de que ele tornou-se branco. Cabe destacar que o grupo selecionado para as entrevistas - professores de ensino básico - teve mais acesso a bens culturais do que bens materiais, o que pode tê-los levado a enfatizar especialmente este aspecto.

Os trechos relacionados ao acesso aos significados de ser branco por parte de negros e ao decesso desses mesmos significados por parte de pessoas reconhecidas socialmente como brancas em alguns contextos sugerem que a troca de significados raciais ora analisada não se efetiva de maneira simétrica, mas está envolta em relações de poder que, em primeira instância, hierarquizam a condição de ser branco e ser negro. Assimetria que se evidencia na avaliação de Cláudio de que sua família toda miscigenada queria ser branca e a minha família negra queria ser branca, ninguém da minha família branca queria ser negro.

Tendo em vista as análises realizadas em capítulos anteriores, o não querer ser negro acompanhado do querer ser branco pode ser compreendido mediante a positividade atrelada à condição de ser branco e à negatividade atribuída à negritude. No entanto, querer ser branco não foi suficiente para o acesso à brancura. Diferentemente dos docentes de aparência ambígua, que dependendo de sua proximidade ou distanciamento dos significados de ser branco puderam negociar sua classificação racial, docentes negros cuja 
aparência não possibilitou ambiguidades em sua categorização se referiram a uma brancura simbólica, mais cultural que fenotípica. Conquanto o branqueamento estético sinalizasse tentativas de apresentar uma brancura no corpo, a escolarização e as habilidades dela decorrentes - erudição, inteligência, eloqüência - configuraram-se de maneira mais proeminente como os significados de ser branco mobilizados neste grupo, indicando que se o corpo não correspondia aos significados de ser branco, sujeitos se consideraram e foram considerados simbolicamente brancos.

Para os docentes que oscilaram sua classificação racial, aqueles cuja aparência poderia condicionar sua autopercepção como brancos, o corpo não adquiriu relevância central, e eles destacaram que outros elementos foram fundamentais na assunção de sua raça. Tendência que se exemplifica na frase de Sara: Eu podia ter ficado do lado dos brancos, eu não fiquei por conta dessas outras características que eu tinha... Como visto, essas características se referiam principalmente às condições socioeconômicas da entrevistada.

Assim, a mobilização dos significados de ser branco por parte de negros disse respeito tanto à dimensão da brancura no corpo - fosse este pensado internamente, por meio da mestiçagem, ou externamente, por meio da modificação de sinais fenotípicos como cabelo, cor da pele e nariz - quanto à segunda dimensão, relacionada à idealização branca, por meio do cultivo de valores associados à brancura. Já as dificuldades encaradas por docentes de classificação racial mais ambígua para a mobilização dos significados de ser branco concentraram-se principalmente na segunda dimensão. O caráter contextual dessas trocas de significados, marcado pelas oscilações de classificação racial de sujeitos considerados brancos em algumas situações e pela ilegitimidade de negros para mobilizarem os significados de ser branco, pareceu estar em conformidade com a definição do status racial com base em critérios que não se resumiram à ascendência e ao fenótipo; ser quase branco (fala de Roberto) ou menos branco dependeu da coinfluência da aparência e de características socioeconômicas e escolares.

Se a brancura apresenta um patamar idealizado caracterizado por uma série de atributos positivos, até mesmo pessoas de aparência branca teriam de esforçar-se para ingressar e permanecer nela, não apenas por meio do corpo, mas do acesso a bens e cultivo de comportamentos a ela associados. Isto é, parece que às vezes nem mesmo brancos conseguem sê-lo completamente, o que remete às discussões realizadas em capítulo anterior sobre as fronteiras internas da brancura. Estas seriam construídas não apenas em 
função do poder aquisitivo e do gênero, mas de outras características socialmente valorizadas ou não, indicando, por exemplo, que ser branco em São Paulo e acessar os valores e privilégios atrelados a essa posição social estaria relacionado à suposta superioridade atribuída à origem regional paulista, o que não significa que nordestinos aparentemente brancos sejam negros ou tratados como tal, mas que sua brancura é problematizada pela origem regional estigmatizada, revelando a existência de fronteiras entre brancos paulistas e brancos nordestinos em que os primeiros têm maior acesso aos privilégios e aos significados de ser branco, já discutidos.

Levando em consideração que a possibilidade de acesso ou decesso aos significados de ser branco é dependente do contexto em que a mobilização desses significados se efetiva, procuro no último capítulo analisar como discursos e interações estabelecidas na escola possibilitam aos sujeitos negros ou brancos mobilizarem os significados de ser branco. 


\section{Mobilizando os significados de ser branco na escola}

As análises realizadas até aqui fomentam a curiosidade a respeito de como os significados de ser branco são construídos e mobilizados por brancos e negros em determinado contexto, como se fazem presentes nas interações estabelecidas numa dada instituição em que se elaboram discursos, de forma mais ou menos explícita, sobre ser branco. Considerando-se os depoimentos tratados, a construção desses significados teve como principais fontes discursivas a família, a escola, a mídia e a vizinhança. Entre essas fontes, a escola apareceu como lócus privilegiado de narrativas e práticas sociais que propiciaram a valorização dos significados de ser branco, permitindo sua mobilização por parte de alunos e professores.

A relevância do contexto escolar nas memórias relativas ao branco pode ser atribuída ao perfil dos entrevistados, já que todos eles eram professores da educação básica e haviam participado de discussões sobre a relevância da raça na escolarização dos sujeitos, bem como estavam particularmente envolvidos em projetos educacionais que visavam à superação do racismo em suas práticas pedagógicas. Além disso, dois dos três blocos de tópicos presentes no roteiro de entrevista que embasou a coleta dos depoimentos estavam centrados nas memórias escolares dos docentes e em sua atuação como professores.

Partindo das características apresentadas pelos docentes como peculiares ao ambiente escolar, pude indagar: quando, como e em que situações a condição de ser branco era discursivamente construída nessa instituição? Quais as características desse discurso? A análise foi centrada nos modos como a brancura se apresentou na experiência escolar dos sujeitos por meio das relações estabelecidas, dos conteúdos ministrados e/ou dos materiais didáticos disponíveis. Para responder ainda que de maneira introdutória a essas questões foram destacadas dos depoimentos as passagens relativas às memórias escolares que remetiam às experiências que os dez sujeitos desta pesquisa viveram na condição de alunos da educação básica, para discutir o que significava para eles ser branco na escola.

Cabe ressaltar que além de informações sobre a trajetória escolar dos professores, as entrevistas traziam tópicos a respeito do exercício da profissão docente. As considerações a respeito desses tópicos também propiciariam a construção de reflexões sobre os sentidos de ser professor branco que, embora sejam de grande relevância para pensar outras possibilidades de inserção de brancos na instituição escolar, não serão 
tratadas nas descrições que se seguem, por questões de tempo e fôlego no contexto da escrita desta dissertação. Mesmo assim, a possibilidade de pensar os significados de ser branco no ambiente escolar a partir de outro ponto de vista, que não o de aluno, é indicativa de que as considerações aqui realizadas não apreendem a totalidade desses significados nem mesmo em se tratando das memórias dos participantes desta pesquisa, sendo possível pensar outras formas de mobilizar tais significados numa mesma instituição.

Para compor este capítulo foram selecionados os excertos das entrevistas que mencionavam brancos na escola, sendo que a reflexão foi organizada em torno de três eixos correlatos cuja análise se ancora nas perguntas acima citadas - o que se fala sobre o branco na escola? Quando, como e por quem esse branco é falado? No primeiro item discuto a presença do branco nos conteúdos ministrados e nos materiais didáticos utilizados; no segundo, apresento os relatos sobre momentos nos quais a brancura foi colocada em destaque nas apresentações e eventos escolares; no terceiro, cito as passagens relativas à interação entre brancos e negros na escola, interações marcadas pela assimetria e pelo privilégio concedido a brancos nos dois eixos anteriores.

\subsection{Ser branco, ser herói - o branco nos conteúdos e materiais escolares}

Uma narrativa construída no masculino e numa perspectiva branca resume as características dadas aos conteúdos escolares pelos entrevistados. Estes revelaram uma monopolização da visibilidade por parte dos brancos, expressa na conclusão de Laura de que os brancos apareciam o tempo todo, todo tempo eles apareciam. Essa visibilidade estava presente nas diferentes disciplinas e nos materiais didáticos utilizados, sendo diversificada somente nas discussões históricas a respeito da colonização. Em tais discussões, negros e índios eram expostos na condição de escravo e nativo, respectivamente, como se a história desses povos tivesse início com a expansão colonial europeia:

Se for verificar como o negro aparece, até hoje, é como escravo. É sempre com essa marca. (Márcio, branco)

História da África nem pensar, nunca tive. Eu lembro que as aulas que eu tive de História era sempre discutindo colonização, no Ensino Fundamental sempre foi mais índio, colonização. (André, ambíguo)

Em comparação, brancos não somente apareciam o tempo todo, como sua aparição se dava em contextos de sucesso, eles eram os representantes legítimos da humanidade nas 
diferentes figuras de livros e murais. Fato que se coaduna ao que pesquisas realizadas no contexto escolar vêm reiterando no que se refere ao silêncio sobre negros e grupos minoritários nas práticas e materiais pedagógicos (LOPES, 1997; GONÇALVES, 1985; CAVALEIRO, 2000).

Essa representatividade estava expressa nas lembranças escolares marcadas pela presença maciça de figuras brancas cunhadas como heróis nacionais. Nesse caso, o uso do masculino é genérico; excetuando-se a Princesa Isabel, que era tratada como uma deusa, nas palavras de uma das professoras de Samuel, todos os principais personagens históricos presentes nos depoimentos eram homens brancos.

Ela [a professora] falava com uma coisa, como se a princesa Isabel fosse uma deusa. Dizia aquilo como se fosse a heroína dos negros. Do Zumbi nunca ouvi falar. Era aquela história, daqueles velhos heróis brancos da elite. (Samuel, branco)

Eu não me lembro de nenhum momento em que a questão do negro fosse tratada. Por exemplo, na aula do Ensino Médio do curso de literatura falava-se de Castro Alves, a professora falava que ele era "O deus dos escravos", ela nem falava poeta dos escravos, era o "deus dos escravos". (André, ambíguo)

Esses "deuses" brancos ultrapassavam a figura do colonizador português, eram tratados nos debates para além da colonização. Brancos estavam nos discursos religiosos, na literatura, na política, nas aulas de História, permitindo pouca, ou nenhuma, identificação por parte dos negros: a gente não conseguia se enxergar. Acho que a gente não participou daquela guerra [Segunda Guerra Mundial] não, sabe?... Acho que não tinha negro naquela guerra, e os exemplos de tudo, de todas as, assim, de todas as... Eram brancos (Laura).

Entre os materiais pedagógicos que possibilitavam a construção do branco como $o$ exemplo de tudo, o livro didático foi apontando como o principal. Segundo Vitória, As figuras do livro eram brancas. Laura lembrou-se que alguns de seus livros traziam fotos impressas e nessas imagens a ausência de mulheres e de grupos raciais diversificados era flagrante:

Nem mesmo Pelé, nada, nada. Em nenhum momento nenhuma mulher. Sempre homens brancos, sempre homens brancos [...] E eram só aqueles personagens que apareciam nos livros mesmo. Essa coisa de Pedro Álvares Cabral, Pero Vaz de Caminha, sabe, era mais essa coisa, voltado para esses homens: Ernesto Geisel, João Batista de Figueiredo... Porque eu lembro que tinha a foto dos caras, mas na verdade eu não lembro, eu não consigo me lembrar de nenhum outro personagem que eles deram 
um enfoque, um destaque, a não ser aqueles do livro didático mesmo, não saía disso, não saía do livro, era uma coisa muito...(Laura)

O depoimento acima destaca que nas narrativas construídas por meio de fotos e textos não havia espaço para mulheres e homens comuns, fossem brancos ou negros. As imagens veiculadas estavam atreladas a determinado tipo de masculinidade branca que, como bem lembrou Samuel, era representante da elite. Embora a conotação de elite não tenha sido explicitada pelo entrevistado, as passagens relativas aos heróis de nossa história lembrados pelos docentes fizeram alusão a, pelo menos, três dimensões de poder: o poder político, o financeiro e o militar, que, em muitos casos, como no caso dos ex-presidentes, estavam interseccionados.

$\mathrm{Na}$ lista de personagens históricas nem todos os brancos estavam visíveis, implicando formas específicas de ser branco nos livros didáticos e aulas que foram referidas com certo distanciamento, mesmo por parte dos docentes autoclassificados como brancos. Daí a referência de Samuel a essas personagens como os heróis da elite e não como os seus heróis.

Todavia, mesmo com esse distanciamento, o fato de que estes personagens e não outros tenham marcado a memória escolar dos sujeitos demonstra a influência exercida pelos discursos que forjaram essas figuras como representativas de nossa História. Nenhum dos entrevistados mencionou heróis populares, mesmo aqueles construídos miticamente, como Tiradentes. As lembranças estavam centradas nesses modelos de ser branco, para os quais a brancura estava relacionada ao poder. A esses brancos poderosos se atribuía a construção de nossa história, uma história que, nas palavras de Samuel, chegava a se confundir com a biografia dos heróis: a História era toda a biografia desses grandes homens [Pesquisadora - Grandes homens brancos...] Brancos, todos brancos. Ser composto por brancos justificaria a visibilidade desse grupo nas fotos e figuras dos livros, contrastando imensamente com a representação conferida às mulheres e a pessoas de outros grupos raciais.

Além dos brancos presentes nas aulas de História, André mencionou grandes nomes da Literatura tais como Castro Alves, Lima Barreto e Machado de Assis. Este último era imaginado por ele como branco. Interessante perceber a associação entre o grande reconhecimento literário e a brancura: mesmo que não houvesse fotos para corroborar a raça atribuída ao escritor, o fato de Machado de Assis estar em posição de destaque nas 
discussões escolares, como visto, lugar ocupado por brancos, pareceu ser suficiente para que André o classificasse como pertencente ao grupo racial branco:

Mas, por exemplo, Lima Barreto, nunca trataram [Pesquisadora: Nunca trataram ou você não sabia que ele era negro?] Eu não sabia e Lima Barreto eu fui conhecer já na faculdade. Machado de Assis eu achava que ele era branco. (André, ambíguo)

A visibilidade de brancos, mesmo que esses "brancos" não apresentassem no corpo a brancura, como no caso de Machado de Assis, foi interpretada por Vitória como resultado de uma história contada a partir de uma perspectiva única, perspectiva que dificultava a problematização de crenças relacionadas não só ao conhecimento escolar, como também a elementos do discurso religioso ${ }^{23}$ :

Como é que a gente vai explicar para as crianças que quem se apossou da leitura e da escrita foi o branco que contou a história do jeito que ele quis? [...] Realmente é muito mais interessante o branco falar que ele nasceu primeiro, que os negros são descendentes de Caim e sei lá o quê, mas que tal contar a verdade? (Vitória, branca)

$\mathrm{Na}$ passagem acima, além de indicar o que se fala - sobre a origem do homem e a explicação bíblica sobre a cor negra -, Vitória identificou o emissor da mensagem, atribuindo tal discurso ao grupo racial branco. Neste mesmo sentido, Samuel salientou que a História aprendida por ele em sua escolarização não só era escrita numa perspectiva masculina e branca - a história daqueles velhos heróis -, como era, segundo o entrevistado, falada por brancos. Ele disse que durante as aulas nunca havia negros falando sobre acontecimentos históricos, mesmo aqueles diretamente relacionados aos próprios negros:

[...] quando eles falavam do 13 de maio, o 13 de maio era encenado, era aquela coisa que todo mundo comemorava. E parece que tinha mais branco falando naquilo do que o próprio negro, você não via o negro falar do 13 de maio, era a professora branca que falava. (Samuel, branco)

Saliente-se que apenas três dos entrevistados lembraram-se do contato com professores negros ao longo de sua escolarização básica, o que explica a conclusão de Samuel de que os episódios históricos eram narrados por brancos. O fato de o 13 de maio ser falado pela professora branca pareceu condicionar o caráter artificial de sua fala,

\footnotetext{
${ }^{23}$ Note-se que nesse excerto, ao contrário dos demais, a entrevistada se posiciona como professora. Outro ponto a destacar é a citação de Caim e não do mito bíblico de Cã para fazer referência à explicação católica para a origem da cor negra: não fica claro se Vitória confunde os dois personagens bíblicos.
} 
artificialidade que se evidencia na percepção de que o 13 de maio era encenado e que se tratava de uma data comemorativa, mais do que uma oportunidade para analisar criticamente o processo de abolição da escravatura.

A análise dos depoimentos permitiu entrever uma crítica à educação escolar de modo geral e ao ensino de História em particular: aquilo a que, tradicionalmente, chamamos de História do Brasil é, na verdade, a história de um grupo específico de pessoas - homens brancos de condição socioeconômica privilegiada. Crítica em si que não representa grande novidade às que já vêm sendo realizadas pelos movimentos negros (SOUZA, 2005) e feministas (ROSEMBERG, 2009) e que possivelmente foi elaborada também com base nos debates realizados no curso de formação em que os entrevistados foram selecionados. Porém, algumas falas chamaram atenção para aspecto pouco tratado nas investigações acadêmicas sobre relações raciais e educação até agora: as maneiras como brancos são representados em livros didáticos e outros materiais. A maioria das discussões que vêm sendo realizadas a respeito dos livros didáticos centra-se na subrepresentação de negros e outros grupos raciais, ou no racismo imbricado nas ilustrações e textos (PINTO, 1987; SILVA, 1995 e 2004) e pouca, ou nenhuma, atenção tem sido dispensada para pensar que "branco" é esse construído pelos materiais pedagógicos da educação básica.

No caso dos depoimentos analisados, ser branco nos materiais didáticos apresentava significados que iam além da percepção da brancura, relacionados ao heroísmo, ao talento, ao poder em suas diferentes dimensões e, principalmente, à visibilidade. A independência relativa desses significados diante do corpo daqueles que os mobilizam de alguma forma tornou possível classificar como brancos figuras cujo comportamento e aptidões remetiam a esses significados, mesmo que sua aparência fosse desconhecida, a exemplo de Machado de Assis, citado por André. Márcio, ao se referir ao mesmo autor, lembrou-se de que as ilustrações de seus livros escolares o representavam por meio do retrato de um branco: E mesmo os heróis nacionais são todos branqueados. Machado de Assis aparecia branco nos livros, citação que demonstra que o entrevistado estava atento ao esforço de alguns autores e ilustradores por fazer coincidir o corpo aos significados de ser branco, neste caso o corpo negro ao talento literário.

Não apenas os materiais didáticos, mas as descrições de eventos e comemorações evidenciaram a possibilidade de construção de outros significados de ser branco, além de ratificar aqueles presentes nos livros e narrativas escolares já descritos. 


\subsection{Os eventos - espaços de brancura}

Se os livros e as narrativas históricas privilegiavam a imagem de pessoas brancas, estas também ocupavam lugar de relevo nas memórias dos eventos realizados em festas e datas comemorativas das escolas frequentadas pelos entrevistados, tendência já apontada por pesquisas que se debruçaram sobre a questão racial no cotidiano escolar (LOPES, 1997; MEYER, 2006). Fato significativo foi que essas lembranças foram exclusivamente citadas por negros, nenhum dos sujeitos brancos fez referência a tais acontecimentos, comuns no cotidiano da maioria das escolas, principalmente aquelas que se dedicam ao público infantil, o que revela que mesmo tendo participado de discussões a respeito de educação antirracista, os docentes autoclassificados brancos não tinham percepção da exclusão de alunos negros dos eventos e apresentações durante seu processo de escolarização, ou que essa percepção não foi considerada relevante a ponto de ser mencionada em suas memórias escolares.

Por isso, a discussão sobre os eventos escolares tomou por base exclusivamente os depoimentos dos docentes negros, numa apropriação da proposta analítica de bell hooks (1999) de que é possível discutir a condição de ser branco a partir de sua construção no imaginário de pessoas negras.

Nas memórias escolares dos sujeitos negros, a escolha de alunas e alunos brancos para representarem os demais nas apresentações e desfiles ou para ocupar posições de destaque em relação ao restante do grupo escolar era unânime. Tais episódios foram descritos como marcantes na trajetória escolar de negros e geralmente emergiram como resposta às perguntas: "Na sua época de estudante, você se lembra de presenciar situações de discriminação e preconceito de qualquer tipo? Descreva-as. Qual foi a atitude dos professores envolvidos? Você participou de alguma situação desse tipo?" As respostas demonstraram não só o envolvimento direto dos entrevistados nessas situações na condição de alvos da discriminação, como a percepção de que essa discriminação estava relacionada ao tratamento diferenciado dispensado a alunos e alunas que os docentes classificavam como brancos. São especificamente as citações a respeito do último aspecto - os espaços que ocupavam os brancos nas situações de discriminação - que interessam a esta análise.

Embora essas referências só sejam compreensíveis mediante o depoimento de como os negros se sentiram em tais momentos, o que remete a tema já bastante discutido na literatura disponível sobre racismo e educação, nesta reflexão esforço-me para descrever os espaços ocupados por alunos e professores brancos nas situações em que a escola era por 
eles representada. Porém, as pesquisas que buscaram desvendar os mecanismos por meio dos quais o racismo é produzido e reproduzido no espaço escolar se constituem como pano de fundo para as análises realizadas (FAZI, 2006; GOMES, 1995; CAVALEIRO, 2000; LOPES, 1997).

Os eventos descritos nos depoimentos puderam ser classificados em três tipos: desfiles, apresentações artísticas e concursos. Começo pelos desfiles. Estes sempre estavam relacionados a datas cívicas como o dia da independência, em que se realizavam os tradicionais desfiles de Sete de Setembro, ou outras datas comemorativas relacionadas à celebração do início da primavera ou aniversários de cidades. Essas apresentações tinham muitas vezes como tema os fatos históricos discutidos no item anterior e reproduziam as mesmas situações presentes nos livros didáticos e aulas. Roberto, por exemplo, lembrou-se de que o aniversário de sua cidade era comemorado com um grande desfile em que participavam alunos de escolas públicas da região e que todos os anos um mesmo carro saía às ruas para encenar a abolição da escravatura:

No dia do aniversário da cidade, que eu não me lembro mais a data, tinha um desfile, e naquele desfile tinha alguns carros alegóricos em que ia sempre uma princesa Isabel, bem loirinha, e um monte de negros acorrentados. Então naquele desfile, sempre... Esse era um dos carros mais esperados, o do D. Pedro, D. Leopoldina, o dos negros acorrentados e a princesa Isabel assinando a Lei Áurea, inclusive essa menina que eu quis namorar e que a mãe não quis [porque ele é negro], quase sempre ela saía como a Princesa Isabel. (Roberto, negro)

Observe-se que a divisão racial correspondia ao que as aulas descritas anteriormente apresentavam: negros escravizados, posteriormente libertados pela princesa bem loirinha. A reprodução de imagens de submissão dos escravos, atualizados na figura de crianças negras acorrentadas, e da benevolência da princesa, corporificada pela aluna branca, ratificavam as narrativas escolares e o destaque positivo conferido aos brancos. A lembrança também surgiu associada à outra discriminação vivida: a menina loira que representava a princesa Isabel foi uma das pretendentes a namoro de Roberto, até que a mãe dela descobriu, e assim, a surpresa minha não foi porque a mãe não queria que a gente namorasse, porque a gente era pequeno. Não tinha essa coisa de que não podia namorar. Não, é porque eu era negro. O desfile não só reportava a distância entre negros e brancos durante o período escravista, como também mantinha a distância entre Roberto e a menina de quem ele gostava e que fora proibido de namorar. 
Noutro desfile cívico, descrito por Laura, os lugares raciais bem marcados e distantes entre negros e brancos também se faziam presentes, dessa vez por meio da encenação de uma obra de Monteiro Lobato, escritor reconhecido por representar personagens negras estereotipadas. Ela se lembrou que pela primeira vez havia sido convidada para participar do desfile e não carregar "não sei o quê"” todo mundo junto; ela seria a única negra em posição de destaque. Porém, soube qual papel iria desempenhar poucos dias antes da apresentação:

[...] eu fiquei feliz, mas eu fiquei triste. Porque, teve um desfile na escola, desfile cívico, aniversário de São Miguel Paulista, e eu fui convidada pra desfilar assim: "Vai ter um desfile", "Tudo bem, vamos desfilar do quê? Como é que vai ser?" Ai a gente ensaiava, mas eles não falavam [...] Uma semana antes do desfile, aí eu fui saber que [...] a parte que eu ia desfilar era do Sítio do Pica-pau Amarelo e eu era a Tia Anastácia, aí o que acontece, eu tinha que ir com um vestidinho assim, com aventalzinho, paninho na cabeça, levar uma panelinha e uma colher de pau. (Laura, negra)

Laura contou que durante o desfile todos imitavam os personagens de Monteiro Lobato, as crianças brancas iam fazendo gracinha, enquanto ela carregava uma panela bem grandinha, sabe assim, colaram um monte de pipoca e eu lá com a colherzinha de pau [...] E eu lembro que eu queria marchar e não podia, era pra ir andando e tinha que mexer a panela. Além da reprodução das hierarquias raciais no desfile, o evento ensejou outros episódios de discriminação para Laura. Já crianças brancas usufruíram a condição de destaque e puderam manter sua individualidade, uma vez que a associação entre alunos e alunas brancas e os personagens que representavam cessou ao final do evento:

A partir daquele momento ninguém mais me chamou de Laura, eu virei Tia Anastácia. Então assim, eu fiquei muito feliz porque me convidaram pra participar do desfile [...] Eu ia junto com a Eliana, a Eliana era a Narizinho, loirinha e tal. E tinha o Pedrinho e o Pedrinho era o Edmilson [...]. Só que todo mundo era chamado pelos seus nomes, o Edmilson era Edmilson, a Eliana por Eliana e eu era chamada de Tia Anastácia.

A coincidência entre a pertença racial dos alunos e dos personagens presentes nas aulas de história e livros de Monteiro Lobato seria a justificativa possível para a escolha de crianças brancas e negras para participarem dos eventos em posições assimétricas, demonstrando como a representação de brancos e negros nos materiais didáticos e conteúdos ministrados tem repercussão para a vida escolar dos alunos para além das aulas, sendo revertida em visibilidade positiva para brancos. 
Provavelmente essa visibilidade estivesse condicionada a outros fatores peculiares à dinâmica escolar, como bom desempenho e comportamento. Samuel, autoclassificado como branco, ofereceu indícios para a associação entre brancura e desempenho escolar: $O s$ brancos geralmente tinham as melhores notas, então era difícil você ver uma criança negra com boas notas. Porém, não houve menções adicionais por parte de Roberto e Laura a respeito das notas e comportamento de colegas brancos escolhidos para participar dos desfiles, assim como também não houve referências a crianças brancas que não participavam dos eventos descritos. Os depoimentos centraram-se naqueles que estavam positivamente visíveis no cotidiano escolar.

A visibilidade de brancos estava presente também em concursos e apresentações artísticas que atualizavam a associação entre brancura e inteligência e brancura e beleza. Esta última foi apontada por Laura como natural no ambiente escolar. Ao rememorar o processo de escolha da aluna que seria a miss primavera, concurso realizado anualmente pela escola para comemorar o início da estação, a entrevistada salientou que as justificativas dadas para a seleção de uma aluna branca faziam alusão direta às características físicas da menina e indicavam abertamente a preferência pela pele clara:

\begin{abstract}
Miss, miss primavera, miss primavera, gente! Era gritante! Aí tinha uma menina que era a Keila, e a Keila parecia índia, mas ela tinha a pele escura, mas o cabelo dela era bem liso, bem liso, aquela coisa, parecia índia, muito, muito bonita. E tinha a Débora, que era o contrário, com a pele clarinha e o cabelo mais... E nós fizemos votação, votar na sala quem a gente achava que deveria ser a miss. $E$ [a escolha] partiu da professora. E a Keila tinha mais votos. E todo mundo "Mas por que a Keila não vai?" "Porque a Débora é mais fácil pra arrumar, pra fazer uma maquiagem, é por isso", foi essa a explicação dela [da professora], "porque a Débora é mais fácil, porque vão vir pessoas que vão maquiar as meninas, que vão pentear..." (Laura, negra)
\end{abstract}

Ao mesmo tempo em que a votação dos alunos diversificaria as características físicas de quem iria estar visível no concurso de miss, uma vez que haviam escolhido alguém que parecia índia, a iniciativa da professora foi chamar atenção para as facilidades que a pele clarinha presumivelmente ofereceria para a maquiagem, justificativa aceita pelo grupo de alunos: Pesquisadora: A Débora era reconhecida como branca? Laura: Era, era. Aí, foi exatamente isso, era mais fácil pra arrumar, e a gente: "Ah, está bom. Ah é mesmo, não pensamos nisso!"

Num concurso literário descrito por Carolina, a escolha de uma aluna branca foi encarada como injustiça pela entrevistada e por colegas. Na escola havia um concurso de 
poemas e, como prêmio, o primeiro colocado publicaria seus textos num livro editado pela instituição. Carolina acreditou ter ficado em segundo lugar em razão de sua pertença racial:

[...] quem ficou em primeiro lugar foi a menina branca, e todo mundo falava "Nossa, mas o seu poema ficou muito mais bonito. Você se expressa muito bem, você escreve muito bem, por que você não ganhou o primeiro lugar?" Eu vou saber por quê?? Eu dizia: "Escolheram ela para o primeiro lugar". (Carolina, negra)

A conclusão de Carolina de que se tratava de um episódio de discriminação se deu por duas razões: a direção da escola propôs que fosse organizada uma segunda publicação para incluir seus poemas, mas essa publicação não tinha o mesmo significado da primeira, já que era organizada por uma pessoa da região e não pela própria escola: Como gostaram dos meus poemas eu me lembro que eles foram publicados num outro livro de uma pessoa da região, mas não foi pelo concurso da escola. E porque identificava outras situações nas quais crianças brancas eram tratadas de maneira privilegiada.

Indagada a respeito dos lugares ocupados por brancos, a entrevistada respondeu, após discorrer longamente sobre as discriminações vividas em diferentes contextos:

Pesquisadora: E o que era apresentado como o lugar do branco?

Carolina: Sempre um lugar bom. Por exemplo, vou dizer na escola. $\mathrm{Na}$ escola o lugar do branco era o que, nas apresentações teatrais as meninas escolhidas eram sempre as brancas, nas fanfarras sempre iam as brancas. Nunca fiz parte da fanfarra da minha escola e tinha, nunca fui chamada, eram só as meninas brancas. No desfile de 7 de setembro, só eram as meninas brancas que iam à frente. (Carolina, negra)

Ir à frente, participar, aparecer, enfim, estar visível sempre em posição favorável em lugar bom - foram as referências ao lugar do branco na escola. Ser bonito (ganhar concurso de miss, ser fácil de maquiar), inteligente ou talentoso (ganhar concurso de poemas, participar de fanfarras)... Essas foram descrições feitas por docentes negros a respeito dos colegas brancos. Já outras situações nas quais crianças brancas fossem junto com negras ao fim de desfiles, não fossem escolhidas para miss primavera, não participassem de fanfarras e/ou outras apresentações, não foram lembradas, indicando que o branco presente em desfiles e apresentações no imaginário dos professores negros, assim como aquele construído por livros didáticos e aulas, era pouco representativo do ponto de vista quantitativo, não englobava a totalidade de experiência de alunos e alunas reconhecidos como brancos.

A ausência de depoimentos que diversificassem a experiência branca na escola no que diz respeito aos eventos escolares pode dever-se a dois fatores: em primeiro lugar, ao 
silêncio de entrevistados brancos em torno dessas questões. Por meio das memórias escolares de brancos poderiam emergir descrições a respeito de outros lugares ocupados por eles mesmos que não remetessem à visibilidade e ao destaque. Segundo, porque as respostas de docentes negros estavam inseridas num contexto em que esses falavam sobre discriminação no ambiente escolar, e o alvo da discriminação tanto nas discussões efetivadas no curso de extensão quanto nas entrevistas era o grupo negro. Provavelmente por isso, não foi possível aos entrevistados formularem as mesmas críticas em relação à exclusão de crianças brancas desses eventos e apresentações, como o fizeram com referência aos lugares ocupados por negros. Estes elementos indicam que na construção dos significados de ser branco pelos professores negros, os exemplos retirados da "vida real" passam por uma seleção, destacando aqueles relacionados à positividade. O que é negativo não foi associado à brancura, exceto para tratar de quem discriminava ou tinha o poder para fazê-lo.

A diversidade de experiências de ser branco na escola tornou-se mais evidente nas análises a respeito das interações estabelecidas entre brancos e negros, interações que às vezes remetiam aos significados descritos nos dois itens precedentes, mas em muitos casos estavam marcadas por outros eixos de privilégio e subordinação.

\subsection{Quem pode ou não mobilizar os significados de ser branco na escola?}

As relações entre brancos e negros na escola foram lembradas em diferentes momentos das entrevistas, não só nos relatos de situações de discriminação vividas ou presenciadas, mas para responder às questões: "Como era o relacionamento entre as crianças de diferentes pertenças raciais e dessas com os professores? Quem eram bons e maus alunos?" Ao contrário do item anterior, as análises a respeito das interações raciais no contexto escolar foram feitas com base nos depoimentos dos dez entrevistados, com destaque para as memórias dos docentes brancos, cujas falas estavam relacionadas à sua própria experiência como alunos brancos.

Um primeiro ponto a ser salientado refere-se à lembrança por parte da maioria dos docentes a respeito da predominância numérica de colegas brancos na escola, fato curioso em se tratando de entrevistados que freqüentaram instituições públicas de ensino e menos surpreendente nos casos de Vitória e Carolina que estudaram em escolas particulares contando com bolsas de estudos. Essa discrepância numérica foi explicada com apoio em diferentes hipóteses: o ingresso no mercado de trabalho antecipado para crianças negras, 
dificuldades financeiras ou no desempenho desigual entre negros e brancos nas atividades escolares:

Eu me lembro que da criança negra, todos os alunos negros desistiam, todos repetiam e desistiam, era raro você ver às vezes um aluno negro. Eu me formei em 1974 no ginásio, antigo ginásio, no fundamental, eu me lembro que alunos negros havia, mas você via que os alunos negros que começavam comigo lá na quinta série, sexta, sétima série eles iam para o período noturno, depois [...] paravam na oitava, quando você via esse menino estava trabalhando na indústria de peão e desistia de estudar. Tem aquela coisa, desistiu porque tinha que trabalhar. E o menino branco continuava estudando e trabalhando. (Samuel, branco)

Primeiro não tinha professores negros, não tinha professores negros, tinha poucos alunos negros estudando [Pesquisadora: por quê?] Então, aí, não era porque não tinha negros, é porque eles ficavam fora da escola mesmo; agora, explicar porque eu não consigo dizer pra você, nem consigo pensar, só sei que tinha muito negro na cidade, mas eles ocupavam pouco a escola. Não sei se, por exemplo, tinha certo limite que a direção não aceitava, ou de fato eles não se preocupavam com o massacre, que já há o cara não vê prioridade, geralmente lá [na Bahia] criança começa a trabalhar muito cedo nos trabalhos mais precários, $e$ ali já estava determinado, eles trabalhavam de ensacar arroz, arrumar fardos, trabalho assim... Não que não tinha branco, mas se você observasse era de fato o espaço que eles [os negros] mais ocupavam. Eu lembro que... quando eu estava na terceira... Ainda tinha alguns, vamos dizer uns dois, três na sala, mas quando eu cheguei na quinta série aí não lembro de ter nenhum. (André, ambíguo)

Nos excertos acima Samuel e André elaboram duas hipóteses para tentar explicar a disparidade entre o número de crianças negras e brancas na escola. Uma mesma hipótese se encontra nos dois depoimentos e diz respeito à suposição de que meninos negros saíam da escola sem concluírem seus estudos por conta de sua inserção no mercado de trabalho. Argumento contestado por Samuel que se lembrou que o início de atividades relacionadas ao trabalho se dava para os meninos de ambos os grupos raciais, mas a evasão seria um fato mais comum para os negros. Já André destacou que a pouca importância dada à escolarização por parte dos sujeitos negros se justificava tendo em vista demandas mais urgentes relacionadas ao trabalho de subsistência, atividades pouco qualificadas e exigentes do ponto de vista físico que eram ocupadas, majoritariamente, por crianças negras. A expressão massacre, utilizada por André, também pode se referir a componentes simbólicos que ensejariam a pouca relevância atribuída por negros à escolarização, componentes que podem estar associados às experiências de discriminação e preconceito.

A partir das especulações dos entrevistados pode-se inferir que crianças brancas eram favorecidas em pelo menos dois pontos: quanto à posição socioeconômica - em que 
pese sua sub-representação nas atividades mais precárias, no caso do depoimento de André - e pela própria dinâmica escolar, já que seu desempenho permitia progressão, ao contrário dos negros que repetiam e desistiam, como citado por Samuel. A última observação foi enfatizada por Samuel em outras passagens nas quais ele afirmou que brancos geralmente tinham as melhores notas, então era difícil você ver uma criança negra com boas notas. Indagado sobre os motivos da diferença de desempenho escolar entre brancos e negros, o docente lembrou-se das manifestações de racismo na escola, mesma justificativa dada por André ao alegar que a maioria dos negros sofria preconceito e saía. Entretanto, André também relatou o caso de um colega branco que apresentava comportamento e notas que contribuíam para sua caracterização como aluno problemático, o que provavelmente não lhe permitiu afirmar, assim como Samuel, que brancos tinham as melhores notas. Para explicar o mau desempenho do colega ele se remeteu ao fato de que ele era filho de uma mulher sem marido e que tinha problemas familiares.

Márcio, também não dividiu racialmente os alunos de acordo com seu desempenho escolar. Segundo ele, não havia separação racial entre os bons e maus alunos, tinha o Carlos que era arteiro demais e era loiro. Tinha o Ricardo que também ia mal, a gente sempre ajudava, mas ele era da pá virada. Em comparação, entre aqueles classificados pelo entrevistado como bons alunos, havia duas crianças negras, um menino e uma menina.

$\mathrm{Na}$ avaliação de Márcio, as diferenças de tratamento dispensado por professores aos alunos e alunas se deviam mais ao comportamento das crianças do que à sua pertença racial: Eles [os professores] davam mais atenção para os bons alunos. Havia certo comportamento esperado. A percepção do docente de que desempenho escolar e raça não estavam necessariamente relacionados também esteve presente nos depoimentos de professores negros. Todos se descreveram como bons alunos e alunas e o bom desempenho nem sempre era sinônimo de tratamento equânime ou de reconhecimento, como citado por Márcio. Carolina se lembrou um tanto frustrada que

Quando eu fui estudar no convento tinha uma ala para pessoas mais ricas e tinha uma ala para as pessoas pobres, dentro dessa ala das pessoas pobres tinha pobres brancas, pobres claras, que sempre sentavam na frente nas carteiras, sempre ficavam fazendo alguma coisa na escola de legal, participando de desfiles, ajudando o professor em alguma coisa, alguma tarefa, era líder da sala. E eu era inteligente, eu ficava me perguntando por que eu não fazia parte do grêmio, por que eu não era líder de sala, por que eu não ia desfilar em sete de setembro, por que eu não era uma das meninas que estavam sempre na frente levando a 
bandeira ou fazendo parte da banda, por que eu sempre tinha que ficar no fundo? (Carolina, negra)

Na fala de Carolina, a ocupação dos espaços da sala e da escola e a possibilidade de efetivar certas atividades foram lembradas como territórios racialmente divididos que ultrapassavam a avaliação do desempenho escolar. A participação nos eventos e apresentações, já discutidos anteriormente, é apenas um dos itens na lista de lugares ocupados por brancos. Na descrição da entrevistada, ser branco também estava relacionado à representatividade - ser líder de sala - e à ocupação de lugares físicos e não apenas simbólicos, como a concentração de meninas brancas nas mesas à frente da sala.

Sandra e Laura também se referiram à ocupação desigual de alunos nas salas, indicando que negros sempre se sentavam ao fundo. A turma de brancos que se sentava à frente da sala ajudava professores e se destacava nas atividades, foi caracterizada por Laura como o pessoal da demanda, grupo em que outros alunos, incluindo ela, gostariam de estar. Para se juntar ao grupo, de acordo com as memórias de Laura, ela oferecia habilidades que ultrapassavam o bom desempenho e comportamento; era preciso certa subalternidade, atualmente criticada por ela:

Pesquisadora: E você conseguia estar no grupo, como era?

Eu conseguia, eu conseguia estar no grupo, e eu não ligava para as outras crianças que não conseguiam [...] minhas primas mesmo, elas nem sempre estavam no grupo, elas não. E eu não ficava com elas, eu ficava com o grupo, porque era aquele espaço que eu havia conseguido, entendeu? Mas, nossa! Tinha aquela coisa de carregar material, eu carregava o material da Eliana, para poder estar no grupo! [Pesquisadora: Quem era o grupo?] Era o pessoal da demanda, porque era aquele grupo que estava ali pra tudo: "Vamos ajudar a professora, vamos varrer o pátio..." [Pesquisadora: Essa turma, além de se destacar para fazer as coisas, como eram as características tanto físicas, econômicas?] [...] O nível deles era meio assim, não vamos falar... eles não eram classe média, lógico, mas só que a condição deles era diferente, dia de chuva o pai ia buscar de carro, e a gente fazia capa de saco de lixo [risos] pra não se molhar e não molhar o material [...] [Pesquisadora: E quem participava do grupo eram os brancos?] Sim! Quando era mesclado, quando era misturado esse grupo? Não era na escola, era do portão pra fora, porque tinha uma coisa do grupo de dentro da escola, e um do portão pra fora, e os grupos eram diferentes. Porque o grupo do portão pra fora era o grupo que nós morávamos perto, que aí esse grupo de primas, e a gente ia embora todo mundo junto, porque geralmente essa turma da escola não morava perto da gente, moravam perto da escola [Pesquisadora: Mais central?] Mais central, e nós ainda íamos subir o morro, íamos atravessar, nós morávamos do outro lado da avenida. (Laura, negra) 
Destaque-se da longa citação a dificuldade da entrevistada em fazer referência à pertença racial dos participantes dos dois grupos. Essas referências só surgiram após pergunta direta que foi respondida com surpresa em se tratando do grupo branco do qual Laura fazia parte dentro da escola. Mas logo em seguida, ao descrever as características do grupo que ela integrava fora da escola, a mesma se ateve à condição socioeconômica e à localização periférica de suas casas. Porém, foi possível classificar as crianças do grupo de fora da escola por meio de outras citações da entrevista, como por exemplo a conclusão de que só havia outros negros na sala quando uma prima caía na mesma turma ilustra bem a composição racial dos primos que se juntavam apenas do portão da escola para fora. Para fazer parte do grupo branco, visível no auxílio a docentes, era preciso para a entrevistada negra carregar o material de Eliana, a mesma colega que interpretou a Narizinho no desfile de aniversário do bairro, em que Laura participou como tia Anastácia, o que evidencia que sua participação não se assemelhava à daqueles classificados como brancos. Estar no grupo era o espaço que ela havia conseguido, implicando que suas primas talvez não tivessem se esforçado o suficiente para conquistar o mesmo espaço.

Nesses trechos, em que estão presentes as considerações de três entrevistadas negras, as descrições se atêm a uma parcela de brancos cuja trajetória escolar permitia o acesso a posições privilegiadas no ambiente escolar. Contudo, o espaço da visibilidade e do privilégio também não estava disponível a todos os brancos e as passagens relativas aos lugares diversificados ocupados por brancos foram citadas somente pelos entrevistados brancos, muitas vezes com base em opressões vividas por eles mesmos na escola.

Nas interações descritas pelos docentes brancos, o "branco" genérico, construído com base em diferentes discursos, dava lugar a experiências concretas nas quais nem sempre foi possível a crianças brancas mobilizarem os significados construídos acerca de seu grupo racial. Em outras palavras, professores brancos nem sempre descreveram a si mesmos em conformidade com as imagens construídas pelos entrevistados negros a respeito dos significados de ser um aluno branco.

Essa impossibilidade estava relacionada a fatores que ultrapassavam a raça e diziam respeito a fatores extraescolares como a origem regional, características familiares e, principalmente, a condição socioeconômica dos entrevistados brancos e de colegas com os quais conviveram. Esses outros eixos de subordinação já foram interpretados nos capítulos quatro e cinco e configuraram-se como atravessamentos na condição de brancos que por vezes impossibilitavam a ocupação de lugares de destaque na escola. Márcio, por exemplo, 
ao ser indagado se participava dos episódios de discriminação destacados em seu depoimento disse que

Na escola foi a primeira vez que eu vivenciei o conflito, além da vizinhança foi na escola. Eu não gostava das coisas que aconteciam [...] As pessoas tinham dificuldade de lidar com o jeito de cada um, minha mãe me orientava para que eu não fizesse parte disso, eu obedecia, era obediente. (Márcio, branco)

A pertença racial da mãe e do avô classificados pelo entrevistado como negra e afrodescendente, respectivamente, foi acionada como explicação para sua postura frente aos maus tratos presenciados. Além de situações nas quais o entrevistado associava as crianças discriminadas a seus familiares, também foram citados momentos nos quais ele próprio era alvo dos xingamentos distribuídos por colegas no intervalo, situações nas quais ele preferia evitar o conflito: Eu ignorava, fazia de conta que não era comigo.

A postura de ignorar situações de preconceito também foi comentada por André. Este, após mudar-se para São Paulo, identificou dois grupos alvos de preconceito, negros e nordestinos, salientando que fazia parte do último:

E aí tem uma questão muito clara, do meu jeito de falar as pessoas não aceitavam. Por exemplo, perguntavam se lá de onde eu vim não tinha carro, sabe umas coisas muito chatas, quando tinha alguma situação em que eu errava, "Ó o baianão", então era uma situação... Eu sempre levei muito bem, só que você percebendo hoje assim... Penso "como é que eu deixei essas coisas assim passarem?” (André, ambíguo)

Vitória que, como Carolina, frequentava uma instituição particular que também mantinha uma escola gratuita nas dependências do colégio referiu-se à existência de conflitos - eu fui estudar na escola gratuita, no colégio $X$, aquele colégio gigantesco, que hoje é uma faculdade. Lá é que eu me deparei o que é estudar na parte gratuita de uma escola de elite. -, mas não os descreveu.

Essas considerações a respeito da existência de discriminação no contexto escolar dirigida a pessoas de aparência branca mostram que esses sujeitos não eram apenas reconhecidos como brancos nesse espaço. André era facilmente caracterizado como baiano em razão de seu sotaque, traço que o depreciava frente aos demais alunos brancos paulistas. Vitória frequentava escola particular na condição de bolsista e tinha sua pobreza acentuada em relação aos colegas de classe média. Márcio era xingado nos momentos do recreio. Entre os docentes brancos, apenas Samuel não relatou episódios em que sua posição privilegiada como branco fosse problematizada. 
Em contrapartida, no ambiente escolar os significados de ser branco puderam ser mobilizados por pessoas aparentemente negras. Emblemático desse processo foi a lembrança de Laura de que a menina que ela classificou durante toda a sua trajetória escolar como branca é hoje classificada por ela como negra:

Hoje eu posso falar: a Débora era negra e ela tinha muito cabelo, muito
cabelo, o cabelo dela era crespo, o cabelo dela... Ela se acabava lá no
Velyn pro cabelo dela dar uma abaixada, mas a Débora tinha a pele bem
clarinha, ela tem a pele bem clarinha, bem clarinha, e era assim, ela só
andava de saia e a Débora tocava piano, gente do céu, o que era ir à
casa da Débora e a Débora tocar. (Laura, negra)

Débora, a mesma aluna que venceu o concurso de miss primavera mencionado por Laura, foi descrita como a melhor aluna da turma. Tocava piano, era evangélica e alisava os cabelos, características que em conjunto com o tom da pele clara conformaram a percepção de Laura, de outros alunos e de professores de que a amiga era branca, demonstrando como o acesso à brancura seria possível tanto por meio de traços culturais quanto fenotípicos.

Cabe salientar que outras investigações realizadas no ambiente escolar cujas análises conjugavam desempenho, classificação racial e gênero apontam para a convergência entre a classificação como branco e o bom desempenho. Carvalho (2004), por exemplo, ao analisar consistências e inconsistências na autoclassificação racial realizada por crianças da quarta série do ensino fundamental e a categorização feita pelas professoras dessas mesmas crianças, observou a tendência de docentes brancas a branquearem seus alunos - categorizarem como brancas crianças que haviam se autoclassificado como pardas ou pretas -, em especial meninas com bom desempenho escolar:

[...] o bom desempenho escolar (incluindo aprendizagem e comportamento considerados adequados) é uma referência na determinação do pertencimento racial, referência forte o bastante para ser incorporada à própria identidade racial de alunos e alunas, pelo menos ao final de quatro anos de escolarização [...] (CARVALHO, 2004, p. 273).

Resta a indagação se no caso ora analisado estaria presente a mesma correlação entre ser a melhor aluna da sala, tocar piano e possuir uma aparência ambígua - pele clara e cabelo crespo - na definição da pertença racial da amiga de Laura como branca.

A mesma passagem sugere que a heteroclassificação racial realizada por Laura a respeito da colega não se manteve estanque, mas foi condicionada pelo contexto. Possivelmente em virtude de sua atual inserção política e escolarização elevada, Laura 
pode, com base em sinais diacríticos apresentados pela colega, como os cabelos, classificála como negra, mesmo que ela apresentasse a pele clarinha, revelando critérios de classificação mais polarizados e menos influenciados pelo contexto escolar em que se deu a primeira classificação.

Nessa e nas demais considerações a respeito da vida escolar dos sujeitos da pesquisa estão presentes as diferentes dimensões dos significados de ser branco tratadas nos capítulos anteriores: a arbitrariedade da atribuição de valores e características à brancura, a independência relativa desses significados em relação à aparência (ao menos em algumas situações), a possibilidade de cultivo desses significados por parte de pessoas reconhecidas racialmente de maneiras diferentes.

Esses significados não são apenas ratificados como também construídos por meio de materiais didáticos, concursos e interações entre alunos e professores e indicam que ser aluno branco, na concepção dos docentes entrevistados, significava poder identificar-se com personagens construídas em destaque, ser eleito em concursos de beleza, permanecer mais tempo e com melhor desempenho na escola, ocupar os espaços físicos da escola de maneira privilegiada. Entretanto, um aluno branco poderia pertencer também a grupos percebidos como subordinados, pertença que embora não inviabilizasse a construção de significados de ser branco como vantagem, dificultava a sujeitos aparentemente brancos ocuparem posições vantajosas na escola, ensejando experiências de opressão. 


\section{Considerações finais}

As reflexões realizadas ao longo desta dissertação tinham como objetivo responder à pergunta “O que significa ser branco?”, formulada com base na ideia de que a brancura que se manifesta nos corpos de pessoas brancas é socialmente construída, ou seja, adquire significado nas relações sociais que sujeitos e grupos estabelecem entre si em diferentes situações.

A diferenciação entre sujeitos negros e brancos e os significados construídos a respeito da pertença racial dos últimos só foi possível por meio do contato com estudos, principalmente norte-americanos e ingleses, que se dedicaram a investigar a identidade racial branca - branquitude -, estudos inicialmente fiéis ao paradigma identitário que elaboravam seus objetos em torno de experiências vividas por pessoas brancas (FRANKENBERG, 1993). Essas pesquisas estimularam o deslocamento de meu interesse pelas trajetórias de vida de professoras negras - tema do projeto de mestrado com o qual ingressei na pós-graduação -, para os modos como pessoas brancas construíam suas identidades raciais e o papel da escolarização neste processo.

Com o avanço dos estudos e leituras, um grupo diferenciado de pesquisas chamoume a atenção pela maneira como construíam seus objetos, centrando-os não em depoimentos de pessoas brancas e sim em construções a respeito da branquitude por parte de sujeitos que se reconheciam racialmente de maneiras diferenciadas. Entre essas pesquisas destacava-se o trabalho de hooks (1999) e o artigo de Twine (1999) - BrownSkinned White Girls -, que sugeria a construção de identidade racial branca por parte de garotas fenotipicamente latinas ou negras de origem socioeconômica favorecida, moradoras de subúrbios de elite nos Estados Unidos. Deste trabalho retirei a premissa de que a identidade racial branca não se constrói apenas em função da cor da pele, já que a brancura não se resume a suas dimensões corpóreas, e do estudo de hooks apreendi que concepções a respeito da branquitude não seriam exclusivamente construídas por pessoas brancas. Devo à leitura desses dois trabalhos a separação entre corpo e significados e a posterior "descoberta" de que o próprio corpo não teria relevância social não fossem os significados que lhe dão moldagem.

As primeiras investigações centradas na branquitude a que tive acesso a construíam como um todo homogêneo baseado no privilégio de ser branco, delimitando fronteiras entre a branquitude e outras construções racializadas subordinadas. A premissa de que a branquitude se diferenciava internamente em virtude de outros marcadores sociais só foi 
elaborada após a leitura dos trabalhos de Wray (2004) e Garner (2007). O primeiro, ao investigar como brancos pobres problematizavam as idealizações da branquitude como unicamente poderosa sugeria que na definição da branquitude fossem consideradas distinções internas na condição de brancos, principalmente aquelas dependentes da classe social, do gênero e da sexualidade. Já Garner, ao estudar como irlandeses foram pensados ao longo da história ora como membros de grupo racial inferior, ora como brancos, deu maior solidez à ideia de que o fenótipo claro não necessariamente possibilita o ingresso na branquitude, reforçando a independência relativa entre corpo e significados ou, se preferível, entre cor e raça.

Ao revisitar clássicos da Sociologia das Relações Raciais brasileiros como Hasenbalg (2005 [1979]) e Freyre (2006 [1933], 2006 [1936]) imbuída desse novo olhar condicionado pelos textos acerca da branquitude, encontrei indícios de que tanto a perspectiva analítica quanto o conceito de "branquidade" estavam presentes nos escritos de Freyre, elaborados ainda na década de 1930, não se tratando, pois, de conceito estrangeiro.

Guardadas as devidas proporções e as particularidades do contexto, as ideias de Freyre permitiram avançar a compreensão da branquitude brasileira para além das polaridades raciais verificadas nos contextos norte-americano e europeu. Entre tantos aspectos da obra freyreana, as análises do autor se mostraram particularmente relevantes e atuais em relação ao material empírico aqui estudado, destacando-se o caráter mestiço dos brancos brasileiros que não impede que parte da população se defina como branca (FREYRE, 2006 [1933] p. 367) as "insígnias de branco" - símbolos de ascensão social associados à brancura, entre eles o diploma de bacharel -, que supostamente arianizaria negros (2006 [1936], p. 709), além de sugestões de que condições socioeconômicas desfavorecidas dificultariam o acesso a tais insígnias (2006 [1936], p. 709).

Porém, o mesmo autor que elaborou algumas ideias que pareceram consonantes com parte daquelas desenvolvidas pelos estudos críticos da branquitude lançou bases para problematizar a utilização do conceito frente às relações raciais brasileiras, uma vez que as considerações freyreanas a respeito da mestiçagem e da democracia racial constituem narrativas de origem que exaltam a ideia de mistura em contraposição àquelas relativas às divisões raciais polares que opõem negros e brancos tal como nos contextos em que o conceito de branquitude foi elaborado (FRY, 2005).

Seja o mito da democracia racial pensado como ideologia cunhada por representantes da elite para minar a mobilização dos negros em torno da raça 
(FERNANDES, 1965) - ideia que, portanto, deve ser combatida em nome da construção de um sistema de classificação racial bipolar -, seja ele entendido como ideologia que embasa a percepção que os brasileiros têm de si mesmos enquanto frutos da mistura de raças - sendo, desse modo, uma violência a tentativa de dividir a população em termos raciais dicotômicos, com negros de um lado e brancos do outro (FRY, op. cit.; SANSONE, 2004; MAGGIE, 2006) -, essa narrativa é tomada como fundamental para a compreensão das relações raciais brasileiras, implicando que conceitos formulados em contextos mais polares com linhas de cor bem definidas não se aplicam às relações que se estabelecem em nossa sociedade.

Levando em consideração o caráter estrangeiro de tais conceituações, optei por abdicar do conceito de branquitude e devido a essa decisão alguns problemas se evidenciaram. O primeiro deles, de ordem linguística, pode ser verificado no emprego de expressões como brancura, ser branco ou condição de branco para referir-me tanto aos sujeitos reconhecidos socialmente como brancos como às conceituações a respeito deles e de sua raça. O termo inglês whiteness é usado tanto como sinônimo de brancura como de branquitude ou branquidade, demonstrando como o conceito engloba tanto a dimensão corpórea quanto a discursiva de ser branco. Essa primeira dificuldade na escolha de um conceito ou expressão que sintetizasse as diferentes dimensões da brancura, efetivando a "taquigrafia acadêmica" de que fala Stolcke (1991), prenunciou um problema teórico: ao separar o corpo dos significados, por meio do uso de expressões como brancura e significados de ser branco, é como se esse corpo fosse pensado como realidade autônoma, como fato objetivo. O uso de branquitude, tal como acima destacado, abarcaria as diferentes dimensões da brancura, tornado desnecessária a explicação recorrente do termo e facilitando não apenas as análises como a leitura do texto.

Conquanto não tenha usado o conceito de maneira direta, as leituras realizadas foram fundamentais para a formulação da pergunta que desencadeou a pesquisa - "O que significa ser branco?" -, bem como para a análise dos resultados obtidos na empiria. Essas análises mostraram que longe de obter uma resposta única e definitiva a essa indagação, os depoimentos de professores negros e brancos da educação básica apontavam para uma multiplicidade de significados de ser branco, construídos com base em, pelo menos, dois elementos: as experiências dos docentes como brancos e/ou com brancos e os discursos da ideologia racial. A ideologia racial pareceu conformar as concepções generalizadas a respeito dos significados de ser branco expressas pelos docentes, indicando consonâncias 
nas respostas, independentemente da pertença racial dos falantes. Os entrevistados salientaram que ser branco significava ser belo, trabalhador, honesto, bondoso, erudito, altamente escolarizado e gozar de maior poder aquisitivo, ideias que sugeriam a superioridade do grupo branco frente aos demais grupos raciais, notadamente o negro, tendo em vista as inúmeras comparações citadas nos depoimentos entre a situação de vida de brancos e negros.

Esse primeiro patamar da brancura corresponde a uma idealização branca (fala de Samuel), que pode ser interpretada como uma estrutura de privilégios, tanto simbólicos quanto materiais, que antecede realizações e características concretas de pessoas reconhecidas socialmente como brancas, fazendo da brancura um ideal ético, estético, econômico e educacional que pessoas negras e brancas buscariam alcançar ao longo de sua trajetória de vida, seja simbolicamente, por meio do cultivo de comportamentos e valores atrelados à brancura, seja corporalmente, por meio da adequação do corpo para corresponder às características que se convencionou relacionar a esta: cabelo liso, nariz fino (fala de Carolina). O caráter idealizado e valorativo assumido pela brancura entendida para além de suas dimensões corporais faz com que sujeitos brancos tenham que construir ativamente sua pertença racial; sua pele branca não lhes assegura o ingresso imediato na brancura, a não ser em contextos nos quais outras características sociais desvalorizadas apresentadas por eles são ignoradas por terceiros.

Esse branco social e historicamente construído é genérico, abstrato, elaborado principalmente segundo a lógica da dicotomia racial branco versus negro, distinção binária hierarquizada em que ao primeiro elemento se atrelam significações positivas e ao segundo negativas. Esses valores associados a ser branco teriam como contexto de emergência as relações marcadas pela dominação colonial e as teorias raciais, ao mesmo tempo em que seriam atualizados por sujeitos brancos dado o conforto em ser reconhecido como portador legítimo desses valores. Essa atualização foi considerada como conscientemente construída por alguns entrevistados, especialmente negros, e como fruto da naturalização e do não questionamento, principalmente por docentes autoclassificados brancos. Essas conclusões parecem se ajustar à proposição de Costa de que

[...] a brancura transcende o branco. Eles - indivíduo, povo, nação ou Estado brancos - podem "enegrecer-se". Ela, a brancura, permanece branca. Nada pode macular esta brancura que, a ferro e fogo, cavou-se na consciência negra como sinônimo de pureza artística; nobreza estética; majestosa moral; sabedoria cientifica, etc. O belo, o bom, o justo e o verdadeiro são brancos. O branco é, foi e continua sendo a manifestação 
do Espírito, da ideia, da Razão. O branco, a brancura, são os únicos artífices e legítimos herdeiros do progresso e desenvolvimento do homem. Eles são a cultura, a civilização, em uma palavra, a "humanidade" (p. 4-5).

Baseando suas conclusões nos resultados da pesquisa realizada por Souza (1990) com sujeitos negros, Costa atribuiu a estes, se não a construção do que estou chamando idealização branca, ao menos sua manutenção. Porém, como se pôde observar ao longo das análises efetivadas neste trabalho, a idealização branca, ou a construção da brancura como sinônimo de "humanidade", é também uma abstração presente no imaginário de pessoas que se reconhecem brancas.

Devido ao caráter hierárquico dessa idealização e tendo em vista seus efeitos nas experiências de sujeitos que se reconhecem e são reconhecidos como negros, a brancura foi relacionada à opressão, única associação negativa mencionada por meus entrevistados que pareceu não se referir apenas às interações estabelecidas com sujeitos brancos, mas a associações generalizadas com a brancura. Daí que a identificação de alguém como branco fosse acompanhada de angústia e medo por parte de sujeitos negros, mesmo que a discriminação racial não se efetivasse.

A semelhança dessas associações entre brancura e valores e outras presentes em estudos realizados em diferentes áreas do conhecimento que enfatizaram, principalmente da perspectiva de negros, que o branco era pensado como superior (CAVALEIRO, 2000; NOGUEIRA, 1998; SOUZA, 1990, entre outros), sugere que tais associações têm algo em comum com aquelas verificadas em outros contextos sociais, como se pode verificar nos trabalhos de Wray $(2004 ; 2006)$ e Roediger $(1991,2004)$ a respeito dos Estados Unidos, de Steyn (2004) sobre a África do Sul e de Garner (2007) sobre a sociedade irlandesa.

As semelhanças da branquitude em diferentes contextos podem estar em conformidade com o que Steyn (op. cit., p. 125) denominou "Narrativa Mestra da Branquitude" um conjunto de discursos forjados durante a expansão colonial europeia, que defendia a superioridade branca em diferentes aspectos e que, para além da especificidade da dinâmica das relações raciais em cada contexto que penetrasse, se configuraria como ponto de partida para a branquitude, seja onde lhe fizessem oposição, seja onde a ela aderissem.

Desse modo, o primeiro patamar dos significados de ser branco caracterizado pela idealização da brancura está bastante próximo daquilo que pesquisas sobre branquitude vêm 
salientando em outras conjunturas, o que possibilitaria um diálogo direto com tais estudos e o uso do conceito de branquitude na investigação da realidade brasileira.

Os relatos analisados nesta pesquisa também sugerem que a idealização branca não é homogênea: ela se diversifica em função do sexo e das condições socioeconômicas, implicando que certas idealizações sejam peculiares a homens ou mulheres e outras, a pobres ou ricos. Disso decorre, por exemplo, que mulheres brancas sejam imaginadas como castas e brancos pobres, como racistas cordiais. As entrevistas também sinalizavam para distinções nos significados de ser branco de acordo com a orientação sexual e origem regional, e possivelmente para muitos outros eixos de privilégio/subordinação não abarcados nesta análise tanto por falta de tempo quanto em razão de meu desconhecimento de estudos que pudessem embasar análises nesse sentido.

O primeiro patamar dos significados de ser branco, tanto em sua homogeneidade quanto em suas distinções internas, foi contrastado às experiências concretas de docentes negros e brancos cujas experiências como brancos ou as interações com pessoas percebidas como brancas possibilitaram o reforço ou a problematização da idealização branca. Ser branco significou ter sua pertença racial entrecruzada por outras posições sociais, nem sempre favoráveis, posições derivadas da identificação de oito dos dez entrevistados como pobres e/ou portadores de outras características físicas e culturais desvalorizadas.

Assim, brancos não se referiram a si mesmos em conformidade com os significados citados no primeiro patamar. $\mathrm{O}$ branco presente nas experiências dos sujeitos era muito mais plural do que o das construções generalizadas. Os docentes socialmente reconhecidos como brancos perceberam a si mesmos não apenas em termos racializados: eram homens ou mulheres, pobres ou filhos da elite, provinham de diferentes regiões do país, estiveram em condição de mobilizar os significados de ser branco ou foram impedidos de fazê-lo tendo em vista sua pertença a grupos estigmatizados, como os nordestinos.

As associações entre a brancura e o escatológico, sugeridas por Sara, eram bastante diferentes da pureza atribuída à condição de ser branco, até mesmo contraditórias, evidenciando que a idealização branca foi contraposta às imagens construídas a partir da interação cotidiana com pessoas percebidas como brancas. Da mesma maneira, se a condição de ser branco foi relacionada à opressão e à discriminação racial, alguns brancos foram anjos da guarda na trajetória de vida de Carolina.

Todavia, esse segundo patamar da brancura não só desmistificou a idealização branca: certas experiências ratificaram alguns significados de ser branco, principalmente 
os relacionados à opressão racial e ao privilégio institucional concedido a brancos e citado por eles mesmos ou por docentes negros.

Considerando-se as experiências dos sujeitos e adotando a premissa de que a branquitude deve ser encarada como "um problema, uma questão que precisa ser teorizada, mais do que um conceito já pronto para ser modificado e adaptado a novos contextos" (SOVIK, 2004, P. 364), indago: que teorizações emergem da reflexão aqui efetivada? Sem pretensão de responder a essa questão, saliento algumas hipóteses elaboradas com base nas análises do material empírico. A primeira delas, construída no terceiro capítulo, sugere que estudar a branquitude no Brasil implicaria atentar para a miscigenação, para a ascendência africana alegada por fenotipicamente brancos e as construções relativas à democracia racial. A branquitude brasileira, ao contrário da norte-americana, abdicaria da ideia de pureza, sem, no entanto, deixar de requerer para si o status de superioridade.

Para avançar teoricamente nesse sentido, seria imprescindível retomar a obra de Gilberto Freyre, considerado o idealizador da democracia racial, investigando como o autor ao mesmo tempo em que concebe as relações entre os diferentes grupos raciais como democrática, continua a construir o branco como ideal de cultura e civilização que brasileiros pretenderiam alcançar, numa versão de arianismo de cunho menos racial e mais culturalista. A branquitude brasileira seria uma branquitude mestiça, ainda que branca.

Uma segunda hipótese assenta-se no fato de que o contexto brasileiro constrói distinções que ultrapassam as categorias consideradas nos estudos estrangeiros sobre branquitude - classe social, raça, gênero e sexualidade. Nesta pesquisa, por exemplo, a regionalidade se configurou como extremamente relevante.

O modo como brancos do eixo Sul-Sudeste predominam economicamente, ou acreditam predominar, e constroem uma imagem de progresso contraposta ao suposto atraso das regiões Norte e Nordeste, praticamente monopolizando as possibilidades de visibilidade midiática, pode sugerir a existência de uma brancura padrão que, se não exclui outras formas de brancura, toma-as como subordinadas. Daí que a idealização branca citada nos depoimentos pareça não se referir aos nordestinos, em especial aos baianos, designação que por vezes funciona como "metonímia de gente do norte" sobre os quais pesam os estereótipos de "imigrante pobre, ignorante, servil, preguiçoso, beócio" (GUIMARÃES, 2002, p.125-126). Esses estereótipos, segundo Guimarães, estão também documentados na obra de Freyre (1936), o que sugere que análises mais aprofundadas da produção intelectual freyreana também propiciariam entender melhor as diferenças 
regionais que construíram o branco do eixo Sul-Sudeste, e talvez o branco paulista, como principal sujeito da idealização branca.

Por fim, considero que as entrevistas e análises realizadas não se referiam diretamente à identidade dos sujeitos, evidenciando que, para além do paradigma identitário, professores classificados racialmente de maneiras diferentes construíram concepções bastante semelhantes a respeito do que significa ser branco. Contudo, as maneiras como essas concepções interferem no processo de construção da identidade racial dos docentes permanece uma incógnita, já que as análises apontam para diferentes dimensões da brancura e para uma pluralidade de modos de se relacionar com elas. Como afirmar, por exemplo, que os professores de classificação racial mais ambígua, Sara e André, possuíam uma identidade branca, quando seus depoimentos indicavam a vivência de situações em que lhes foi dificultado o acesso a significados que eles mesmos haviam destacado como indicativos de brancura? Ou ser assertiva quanto à possibilidade de sujeitos negros que se declararam branqueados construírem uma identidade branca quando experimentaram a categorização como negros e as implicações sociais dela decorrentes?

Com exceção do trabalho de McIntyre (1995), os demais textos sobre branquitude consultados a definiam como uma identidade racial. Já nesta dissertação a branquitude se relacionou a construções baseadas na raça que teriam impacto tanto no imaginário de negros quanto de brancos, e a utilização do conceito de identidade como condição para o estudo da branquitude não se mostrou indispensável.

Levando-se em consideração as implicações educacionais deste estudo, alguns pontos mereceriam aprofundamento em futuras pesquisas, notadamente a investigação dos sentidos assumidos pelo branqueamento na instituição escolar. Que critérios, para além do fenótipo, condicionariam a percepção de um aluno como branco? Seria a ideia de desempenho escolar construída também a partir de significados de ser negro ou branco? Como os significados de ser branco se evidenciam na prática pedagógica, no cotidiano da sala de aula, nas interações entre alunos? Como é atualmente representado o branco em livros e outros materiais didáticos?

Se as indagações acima permaneceram sem resposta, uma vez que extrapolam os objetivos do presente trabalho, foi possível esboçar uma resposta à questão formulada por Ribeiro (2002) - “Até quando educaremos exclusivamente para a branquitude?" -, a partir da proposição de outra questão: “Até quando educaremos para a branquitude?" tendo em vista que os significados de ser branco aqui discutidos sugerem que os sentidos 
dessa identidade racial, construídos também no ambiente escolar, se consolidam com base na ideologia racista e dão sustentação à superioridade de brancos? 


\section{Referências bibliográficas}

ALLEN, Theodore. The invention of White race. Vol. I - Racial oppression and social control. London: Verso, 1994.

AHMED, Sara. Declarations of whiteness -The non-performativity of Anti-racism. In: Borderlands e-journal, vol. 3, $\mathrm{n}^{\mathrm{o}}$ 2, 2004. Endereço da web: http://www.borderlands.net.au/vol3no2_2004/ahmed_declarations.htm

APPLE, Michael. Consumindo o outro - Branquidade, educação e batatas fritas baratas. In A Escola Básica na Virada do Século - cultura, política e currículo. São Paulo: Cortez, 2002.

ARAÚJO, Ricardo Benzaquen. Guerra e Paz: Casa-grande e Senzala e a obra de Gilberto Freyre. Rio de Janeiro: Ed. 34, 1995.

BACK, Les and WARE, Vron. Out of Whiteness - color, politics and culture. Chicago Press, 2002.

BARBOSA, Luciene Cecília. Racismo e branquitude: Representações na telenovela Da Cor do Pecado. São Paulo : Imprensa oficial, s/d. pp. 5-9.

BASTIDE, Roger. Color, Race and Christianity. In: Daedalus, Vol. 96, No 2 Color and Race (Spring, 1967), pp. 312-327.

BENTO, M. S. Branquitude e Branqueamento no Brasil. In Psicologia Social do Racismo p. 25-57. Rio de Janeiro: Vozes, 2002 a.

Branquitude - o lado oculto do discurso sobre o negro. In Psicologia Social do Racismo p. 147-162. Rio de Janeiro: Vozes, 2002b.

Pactos narcísicos no racismo: branquitude e poder nas organizações empresariais e no poder público. Tese apresentada ao departamento de Psicologia Social da Faculdade de Psicologia da Universidade de São Paulo, 2002c.

BILDEN, Rudigen. Brazil Laboratory of Civilization. New York: The Nation, 1929.

BOGDAN, Robert e BIKLEN, Sari. Investigação qualitativa e educação: Uma introdução à teoria e aos métodos. Porto: Porto Editora, 1994.

BRANDÃO, André Augusto e MARINS, Mani Tebet. Cotas para negros no ensino superior e formas de classificação racial. In: Educação e Pesquisa, v.33, n.1. São Paulo jan/abr, 2007. 
CARNEIRO, Aparecida Sueli. A construção do outro como não-ser como fundamento do ser. Tese apresentada ao departamento de Filosofia da Educação da Faculdade de Educação da Universidade de São Paulo, 2005

CARONE, Iray (org). Psicologia Social do Racismo. Rio de Janeiro: Vozes, 2002.

CARVALHO, Marília Pinto de. Um lugar para o pesquisador no cotidiano da escola. In: Zago, Nadir; Carvalho, Marília; Vilela, Rita Amélia T.. (Org.). Itinerários de pesquisa: perspectivas qualitativas em sociologia da educação. $1^{a}$ ed. Rio de Janeiro: DP\&A, 2003, p. 207-222.

O fracasso escolar de meninos e meninas: articulações entre gênero e raça. In Cadernos Pagu (22) 2004; pp.247-290.

COSTA, Jurandir Freire. Da cor ao corpo - a violência do racismo In Prefácio de Tornarse negro - ou as vicissitudes do negro brasileiro em ascensão social. Rio de Janeiro : Edições Graal, 1990, $2^{a}$ edição.

CAVALEIRO, Eliane dos Santos. Do silêncio do lar ao silêncio escolar: racismo, preconceitos e discriminação na educação infantil. São Paulo : Contexto, 2000.

DAMASCENO, Caetana. "Em casa de enforcado não se fala em corda": notas sobre a construção social da "boa” aparência no Brasil. In Tirando a Máscara: ensaios sobre o racismo no Brasil. Guimarães, A.S.A. e Huntley, Lynn (orgs.). São Paulo: Paz e Terra, 2000.

DIAS, Lucimar Rosa. Cabelos crespos, gênero e raça: práticas pedagógicas de combate ao racismo na educação infantil. In Mulheres e desigualdades de gênero. Marília P. de Carvalho e Regina P. Pinto (orgs.) São Paulo: Contexto, 2008.

DOMINGUES, Petrônio José. Negros de almas brancas? A ideologia do branqueamento no interior da comunidade negra em São Paulo, 1915-1930. In Estudos Afro-asiáticos, Ano 24, n³, 2002, pp.593-599.

DURHAM, Eunice. A pesquisa antropológica com populações urbanas - problemas e perspectivas. In Cardoso (org) A aventura antropológica. Rio de Janeiro: Paz e Terra, 1986.

DYER, Richard. White. In Screen, 29 (4), pp 44-64, 1988.

DZIDZIYENO, Anani. 1971. The Position of Blacks in Brazilian Society, London, Minority Rights Group.

FAZZI, Rita de Cássia. O drama racial de crianças brasileiras: socialização entre pares e preconceito. Belo Horizonte : Autentica, 2006 
FERNANDES, Florestan. A Integração do Negro na Sociedade de Classes, Cia Editora Nacional: São Paulo, 1965.

FERREIRA, Aurélio B. H. Novo dicionário da Língua Portuguesa. Rio de Janeiro : Nova Fronteira, $2^{\text {a }}$ edição, 1993.

FIGUEIREDO, Ângela. Fora do jogo: a experiência dos negros na classe média brasileira. Cadernos Pagu (23), julho-dezembro de 2004, pp. 199-228.

FOLHA. Racismo Cordial. São Paulo: Instituto datafolha, 1995.

FRANKENBERG, Ruth. White women, race matters - The social construction of whiteness. University of Minnesota Press, 1993.

A miragem de uma branquidade não marcada. In Branquidade identidade branca e multiculturalismo. Vron Ware (org); tradução Vera Ribeiro. Rio de Janeiro: Garamond, 2004

FRAZIER, Frazier, Franklin E. Some Aspects of Race Relations in Brazil. In: Phylon (1940-1956), VoI. 3, No. 3, 1942)

FREYRE, Gilberto. Casa-grande e Senzala. Formação da família brasileira sob o regime da economia patriarcal. 51 a ed. rev. - São Paulo : Global, 2006 [1933].

Sobrados e Mucambos - Decadência do patriarcado e desenvolvimento do urbano. São Paulo: Global, 2006 [1936]

FRY, Peter. A persistência da raça: ensaios antropológicos sobre o Brasil e a África Austral. Rio de Janeiro: Civilização Brasileira, 2005.

GARNER, Steve. Whiteness na introduction. London: Routledge, 2007.

Atlantic Crossing: Whiteness as a Transatlantic experience. In: Atlantic Studies, Vol. 4, No 1, April 2007.

GEERTZ, Clifford. A Interpretação das Culturas. São Paulo : Guanabara, 1995

GIACOMINI, Sonia Maria. Mulatas profissionais: raça, gênero e ocupação. Rev. Estud. Fem. [online]. 2006, vol.14, n.1, pp. 85-101

GIROUX, Henry. Rewriting the discourse of racial identity: Towards a pedagogy and politics of whiteness. In: Harvard Educational Review: Cambridge; Vol. 67 Issue: 2 Summer, 1997

GOMES, Nilma Lino. A mulher negra que vi de perto. Belo Horizonte: Mazza edições, 1995.

Sem perder a raiz - corpo e cabelo como símbolos da identidade negra. Belo Horizonte : Autêntica, 2006. 
Diversidade étnico-racial em educação no contexto brasileiro: algumas reflexões. In Um olhar além das fronteiras - educação e relações raciais. Nilma Lino Gomes (org), Belo Horizonte: Autêntica, 2007.

A questão racial na escola - desafios colocados pela implementação da Lei 10639/2003. In Multiculturalismo - diferenças culturais e práticas pedagógicas. Candau e Moreira (orgs). Petrópolis : Vozes, 2008

GONÇALVES, Luis Alberto Oliveira. O silêncio, um ritual pedagógico a favor da discriminação racial: estudo acerca de discriminação racial nas escolas públicas de Belo Horizonte. Universidade Federal de Minas Gerais, dissertação de mestrado, 1985. GUIMARÃES, Antonio Sérgio Alfredo. Racismo e Anti-racismo no Brasil. São Paulo: Editora 34, 1997.

O lugar de onde falo. Fala de abertura para o debate do livro "Tirando a máscara: ensaios sobre racismo no Brasil, jornal A folha de São Paulo, São Paulo, 12 de dezembro de 2000.

Apresentação. In Tirando a Máscara: Ensaios sobre o racismo no Brasil. São Paulo : Paz e Terra, $1^{\text {a }}$ edição, 2000b.

A questão racial na política brasileira. In Tempo Social, novembro de 2001, vol. 13, n. 2, p.121-142.

Classes, raças e democracia. São Paulo: Editora 34, 2002.

Depois da democracia racial. In Tempo Social, revista de sociologia da USP, v.18, n.2, 2006

Preconceito racial. São Paulo: Cortez, 2008

HALL, Stuart. Quem precisa de identidade? In Identidade e diferença - a perspectiva dos Estudos Culturais. Hall, Woodward e Silva (orgs) Rio de Janeiro: Vozes, 2000.

HARAWAY, D. Saberes localizados: a questão da ciência para o feminismo e o privilégio da perspectiva parcial. In Cadernos Pagu, 1995.

HARRIS, Cheryl. Whiteness as a Property. In Harvard Law review. n. 106, june, 1993.

HARRIS, Marvin. Town and Country in Brazil. New York: Columbia Press, 1971.

HASENBALG, Carlos. Discriminação e desigualdades raciais no Brasil. $2^{\mathrm{a}}$ ed. Rio de Janeiro: IUPERJ, 2005.

HOFBAUER, Andreas. Uma História do Branqueamento ou o Negro em Questão. São Paulo: Editora UNESP, 2006 
hooks, bell. Intelectuais Negras. In: Estudos Feministas. IFCS/UFRJ - PPCIS/UFRJ vol. $3 \mathrm{n}^{\circ} 2,1995$, p. 465.

Representing Whiteness in the Black Imagination. In Displacing whiteness. Ruth Frankenberg (org), Duke University Press, 1999.

IGNATIEV, Noel. The point is not to interpret whiteness but to abolish it. Talkin given at the conference "The Making and Unmaking of Whitenes", University of California, Berkeley, Aprifl, 11-13, 1997. Disponível em: www.racetraitor.org.

JUPP, James C. Life histories of white male teachers of diverse students: Intersections with whitenees, masculinity and difference. Presented to the Faculty of the Graduate School of The University of Texas at Austin in Partial Fulfillment of the Requirements for the degree of Doctor of Philosophy.

LENOIR, Remi. Iniciação à prática sociológica. Petrópolis: Ed. Vozes, 1996.

LOPES, Ana Lúcia. Caminhos e descaminhos da inclusão do aluno negro no sistema educacional. São Paulo: Tese apresentada ao Departamento de Antropologia da Faculdade de Filosofia, Letras e Ciências Humanas da Universidade de São Paulo, 2005.

Ampliando o olhar: um estudo sobre a construção da identidade da criança negra-mestiça frente à experiência escolar. Dissertação de mestrado realizado no departamento de Sociologia da Faculdade de Filosofia, Letras e Ciências Humanas da Universidade de São Paulo. São Paulo, 1997.

MAGGIE, Yvonne. Uma nova pedagogia racial? In: Revista da USP. São Paulo, v.68, n. 22, pp.112-129, 2006.

McINTYRE, Alice. Making Meaning of whiteness: Participatory action research with white female student teachers. Boston college, 1995.

MEYER, Dagmar E. Estermann. Das (im)possibilidades de se ver como anjo. In Experiências étnico-raciais para a formação de professores. Gomes e Silva (orgs). Belo Horizonte : Autêntica, 2006.

MILLS, Charles Wright. A imaginação sociológica. Rio de janeiro : Zahar, 1969

MOUTINHO, Laura. Razão, cor e desejo. São Paulo : UNESP, 2004

"Raça", sexualidade e gênero na construção da identidade nacional: uma comparação entre Brasil e África do Sul. Cad. Pagu [online]. 2004, n.23, pp. 5588. 
MUNANGA, Kabengele. Rediscutindo a mestiçagem no Brasil. Rio de Janeiro : Vozes, 1999.

NASCIMENTO, Elizabeth Larkin. O sortilégio da cor - identidade afro-descendente no Brasil. Tese realizada no Departamento de Psicologia Escolar e do Desenvolvimento Humano. Universidade de são Paulo, 2000.

NOGUEIRA, Izildinha. Significações do corpo negro. Tese de doutorado realizada no Instituto de Psicologia da Universidade de São Paulo, São Paulo, 1998

NOGUEIRA, Oracy. Preconceito racial de marca e Preconceito racial de origem Sugestão de um quadro de referência para a interpretação do modelo de relações raciais no Brasil. In Tempo Social, revista de sociologia da USP, v.19, n.1., 2007 [1954]

NORVELL, John. A brancura desconfortável das camadas médias. In Raça como Retórica: a construção da diferença. Maggie e Rezende (orgs.). Rio de Janeiro: Civilização Brasileira, 2002

OLIVEIRA, Lucio O. A. Expressões de vivências da dimensão racial de pessoas brancas: representações de branquitude entre indivíduos brancos. Dissertação apresentada ao programa de pós-graduação em Psicologia Social. Universidade Federal da Bahia, 2007.

PINTO, Regina Pahim. A representação do negro em livros didáticos de leitura. Cadernos de Pesquisa da Fundação Carlos Chagas, São Paulo, n. 63, p. 88-92, 1987.

PIZA, Edith. Branco no Brasil? Ninguém sabe, ninguém viu. In: Antonio Sérgio Alfredo Guimarães e Lynn Huntley (orgs.) São Paulo: Paz e Terra/SEF, 2000.

Porta de Vidro: entrada para a branquitude. In Psicologia Social do Racismo

- Estudos sobre branquitude e branqueamento no Brasil. Bento e Carone (orgs) Rio de Janeiro : Vozes, 2002a.

PIZA, Edith e ROSEMBERG, Fúlvia. A cor nos censos brasileiros. In Psicologia Social do Racismo - Estudos sobre branquitude e branqueamento no Brasil. Bento e Carone (orgs) Rio de Janeiro : Vozes, 2002b.

RAMOS, Alberto Guerreiro. Patologia social do branco brasileiro. Jornal do Comércio, janeiro de 1955.

RIBEIRO, Romilda Iyakemi. Até quando educaremos exclusivamente para a branquitude? Redes-de-significado na construção da identidade e da cidadania. In: POTO,M R S, CATANI, A M, PRUDENTE, C L e GILIOLI, R S. (orgs) Negro, educação e multiculturalismo: Editor Panorama, 2002. 
ROEDIGER, David R. The Wages of Whiteness: race and the making of the American Working Class. New York: Verso, 1991.

Sobre autobiografia e teoria: uma introdução. In Vron Ware (org) Branquidade: Identidade branca e multiculturalismo. Rio de Janeiro: Garamond, 2004.

ROSEMBERG, Fúlvia; MOURA, Neide C; SILVA, Paulo V. B. Combate ao sexismo em livros didáticos: construção da agenda e sua crítica. In Cardenos de Pesquisa, vol. 29, n. 134, São Paulo, mai/ago, 2009.

SANSONE, Lívio. Negritude sem Etnicidade: O local e o Global nas relações raciais. Salvador: Edufba : Palas, 2004.

SCHWARCZ, Lilia Moritz. O espetáculo das raças - cientistas, instituições e questão racial no Brasil 1870 - 1930. São Paulo: Companhia da Letras, 1993.

SCOTT, Joan W. O enigma da igualdade. In Revista de Estudos Feministas, Florianópolis, 13(1): 216, janeiro/abril, 2005.

SILVA, Nelson do Valle. Distância social e casamento inter-racial no Brasil. In: Estudos Afro-asiáticos, nº 14, 1991

SILVA, Ana Célia. A discriminação do negro no livro didático. Salvado: CED e CEAO, 1995.

SILVA, Denise Ferreira da. À Brasileira: racialidade a escrita de um desejo destrutivo. In Revista Estudos Feministas, v. 14 n.1 Florianópolis, jan./abr. 2006.

SLEETER, Christine E. How white teachers construct race. In Race, Identity and representation in education. MarcCarthy e Crichlow (orgs.) New York: Routlege, 1993. Critical Multicultural curriculum and the standars movement. In English teacher: Practice and Critique. September, 2004, Volume 3, No 2. pp. 122-138. Disponível em: http://education.waikato.ac.nz/jounal/uplods/files/2004v3n2dial.pdf

SOARES, Sergei. A demografia da cor: A composição da população brasileira de 1890 a 2007. In: As políticas públicas e a desigualdade racial no Brasil: 120 após a abolição. Mário Theodoro (org). Brasilia : IPEA, 2008.

SOUZA, Neusa Santos. Tornar-se negro: as vicissitudes da identidade do negro em ascensão social. Rio de Janeiro: Graal, 1990, $2^{a}$ edição.

SOVIK, Liv. Aqui ninguém é branco - hegemonia branca e media no Brasil. In Branquidade identidade branca e multiculturalismo. Vron Ware (org); tradução Vera Ribeiro. Rio de Janeiro: Garamond, 2004. 
STEYN, Melissa. Novos matizes da "branquidade": a identidade branca numa África do Sul multicultural e democrática. In Branquidade identidade branca e multiculturalismo. Vron Ware (org); tradução Vera Ribeiro. Rio de Janeiro: Garamond, 2004.

STOLCKE, V. Sexo está para gênero assim como raça para etnicidade? Estudos AfroAsiáticos. Rio de Janeiro, v. 20, p. 101-119, 1991.

TATUM, Beverly Daniel. Talking about Race, Learning about Racism: the application of racial identity development theory in the class room. In Harvard Educational Review. V. 62, n. 1. Spring 1992.

TELLES, Edward. Racismo à brasileira. Rio de Janeiro : Lumará, 2003

UNIVERSIDADE DE SÃO PAULO. Sistema Integrado de Bibliotecas da USP Diretrizes para a apresentação de teses e dissertações da USP: documento eletrônico impresso parte I (ABNT), Vânia Martins B. de Oliveira Funaro, coordenadora... [et al.] - 2 ed. São Paulo : Sistema Integrado de bibliotecas da USP, 2009.

VALENTE, Ana Lúcia. Ação afirmativa, relações raciais e educação básica. In Revista Brasileira de Educação, Jan/Fev/Mar/Abr de 2005, nº 28 p. 62-76.

WAGLEY, Charles. On the Concept of Social Race in the Americas. In: Heath and Adams (orgs.) Contemporary Cultures and Societies of Latin American. New York: Random House, 1965.

WARE, Vron. O poder duradouro da branquidade: "um problema a solucionar". Introdução. In Branquidade identidade branca e multiculturalismo. Vron Ware (org); tradução Vera Ribeiro. Rio de Janeiro: Garamond, 2004.

WRAY, Matt. Pondo a ralé branca no centro: implicações para pesquisas futuras. In Branquidade - Identidade branca e multiculturalismo. Rio de Janeiro: Garamond, 2004. Not Quite White - White trash and the boundaries of whiteness. Duham and London: Duke University Press, 2006. 
ANEXOS 


\section{ANEXO A - Roteiro de entrevista semi-estruturada}

\section{Infância}

- Onde você nasceu e cresceu?

- Fale-me sobre sua família (composição racial, nível socioeconômico, origem dos pais)

- Você tinha contato com pessoas de origens raciais diversas? Como era esse contato, onde essas pessoas moravam?

- Como seus pais e outros adultos consideravam o convívio com pessoas de cores diferentes?

- O que a possibilidade de estudar representava para sua família? E para você?

\section{Escola}

- Quando entrou na escola? Que tipo de escola era?

- Como era seu relacionamento com colegas, professores(as) e outras pessoas?

- Como eram seus colegas de escola.? Quem eram os melhores alunos? E os piores?

- Com quais alunos costumava brincar? Qual era a cor deles?

- Como eram seus professores? Fale daqueles/as que te marcaram positiva ou negativamente. Por quê?

- Na sua época de estudante, você se lembra de presenciar situações de discriminação e preconceito de qualquer tipo? Descreva-as. Qual foi a atitude dos(as) professores(as) envolvidos(as)? Você participou de alguma situação desse tipo?

- Descreva o contato que teve com conteúdos relativos ao negro e sua cultura durante sua escolarização básica, como você avalia as informações que obteve?

- Como você acha que as pessoas negras e brancas se relacionavam com a escola, com o conhecimento, e os colegas?

- Você se lembra como era o relacionamento entre professores e crianças negras? E com as crianças brancas?

\section{Formação e atuação profissional}

- Por que decidiu tornar-se professor(a)? Como se preparou para exercer a profissão? 
- Você acha que essa formação lhe garantiu informações adequadas sobre a diversidade racial de nosso país e sobre o trabalho com alunos de diferentes raças? Por quê?

- O que você entende por diversidade racial? Quando falamos de diversidade racial você acredita que estamos falando de quais grupos? Você pertence a algum desses grupos?

- Você acha que o pertencimento racial influencia a vida das pessoas negras? E das pessoas brancas? Como e por que se dá essa influência? Existem diferenças de influências de acordo com o sexo da pessoa?

- O que significa ser homem negro (e mulher) para você? Descreva as facilidades e dificuldades

- E o que significa ser branco (e mulher)? Descreva facilidades e dificuldades

- Por que você participou de um curso sobre o negro e sua cultura? Você acha que as discussões efetivadas no curso modificaram a percepção que você tinha sobre o negro? E sobre o branco? Como?

- Você já trabalha com questões tratadas no curso em seu cotidiano profissional? Por que realiza (ou não) esse trabalho? Se já realiza conte um pouco como aborda a questão. Como é a receptividade de colegas de trabalho e alunos(as) com relação ao tema?

- Você acredita que trabalhar com essa temática é relevante para a vida de seus(suas) alunos(as)? Por quê?

- Você já presenciou situações de discriminação racial em seu cotidiano profissional protagonizadas por alunos(as)? E por professores(as) ou outros membros do grupo escolar? Como reagiu?

- Você acha que essas situações vividas na escola afetam a vida das pessoas negras e brancas? Como e quais as diferenças para umas e outras?

- Essas situações te afetam? Por quê? 


\section{ANEXO B - Questionário socioeconômico}

\section{Universidade de São Paulo \\ Pesquisadora: Luciana Alves - mestranda em Sociologia da Educação}

Aviso: As informações abaixo serão utilizadas para fins de pesquisa, será assegurado anonimato.

\section{Dados pessoais}

\section{Questionário}

Nome

e-mail

Idade Raça Cor

Natural de

Sexo? Fem. ( ) Masc. ( )

Escolaridade da mãe

Escolaridade do pai

\section{Escolaridade}

Ensino Fundamental Escola Pública ( ) Escola privada ( )

Ensino Médio Escola pública ( ) Privada ( )

Ensino Superior Escola Pública ( ) Privada ( ) Curso

\section{Dados profissionais}

É professor(a)? Sim ( ) Não ( )

Se professor em que nível de educação trabalha: Educação Infantil ( ) Ensino Fundamental ( ) Ensino Médio ( ) Ensino Superior ( ) Outros ( ) Quais?

Instituição pública ( ) privada ( ) outras ( ) Qual

Há quantos anos é docente?

Se não é professor(a) qual é sua profissão?

Faixa salarial 1-2 salários mínimos ( ) 3-4 salários mínimos ( ) 4-5 salários mínimos 5-6 salários mínimos 7 ou mais ( )

Como tomou conhecimento do curso?

Por que está freqüentando um curso dessa natureza?

Já freqüentou outro curso com temática semelhante à discutida neste curso? Qual? 
Utiliza as informações do curso em seu cotidiano? Em que situações?

Participa de algum movimento social relacionado à temática do curso ou a qualquer outro assunto? Qual? Quais são as principais ações desenvolvidas?

As discussões realizadas no curso modificaram a percepção que você tem acerca da questão racial em nosso país? Em que medida?

Em qual grupo de cor você se classifica:

Preto ( )

Pardo ( )

Branco ( )

Amarelo ( )

Indígena ( ) 


\section{ANEXO C - Termo de consentimento livre e esclarecido}

Concordo em participar, como voluntário(a), do projeto de mestrado intitulado $\underline{\mathbf{A}}$ construcão dos significados de ser branco que tem como pesquisadora responsável Luciana Alves, aluna do Programa de Pós-graduação da Faculdade de Educação da Universidade de São Paulo. O referido projeto tem por objetivo:

- Mapear na trajetória de vida e profissão dos sujeitos da pesquisa os usos e significados assumidos pela ideia de raça e de brancura.

Estou ciente de que minha participação se dará por meio de concessão de entrevista e do preenchimento de questionário e de que este estudo possui finalidade de pesquisa. Os dados obtidos serão divulgados seguindo as diretrizes éticas da pesquisa, com a preservação do anonimato dos participantes, assegurando, assim sua privacidade. Estou ciente que posso abandonar a minha participação na pesquisa quando quiser e que não receberei nenhum pagamento por esta participação.

Assinatura

Local e data. 